\title{
Individualizando la nueva generación estelar en NGC 604: Estudio fotométrico infrarrojo con Gemini-NIRI
}

\author{
Tesis de presentada \\ para obtener el grado de \\ Doctor en Astronomía
}

Autora:

Lic. Cecilia FAriña

Director de Tesis: Dr. GUILlERMO L. BosCH Codirector de Tesis: Dr. RODOLFO H. BARBÁ

Universidad Nacional de La Plata Facultad de Ciencias Astronómicas y Geofísicas

Marzo de 2011 


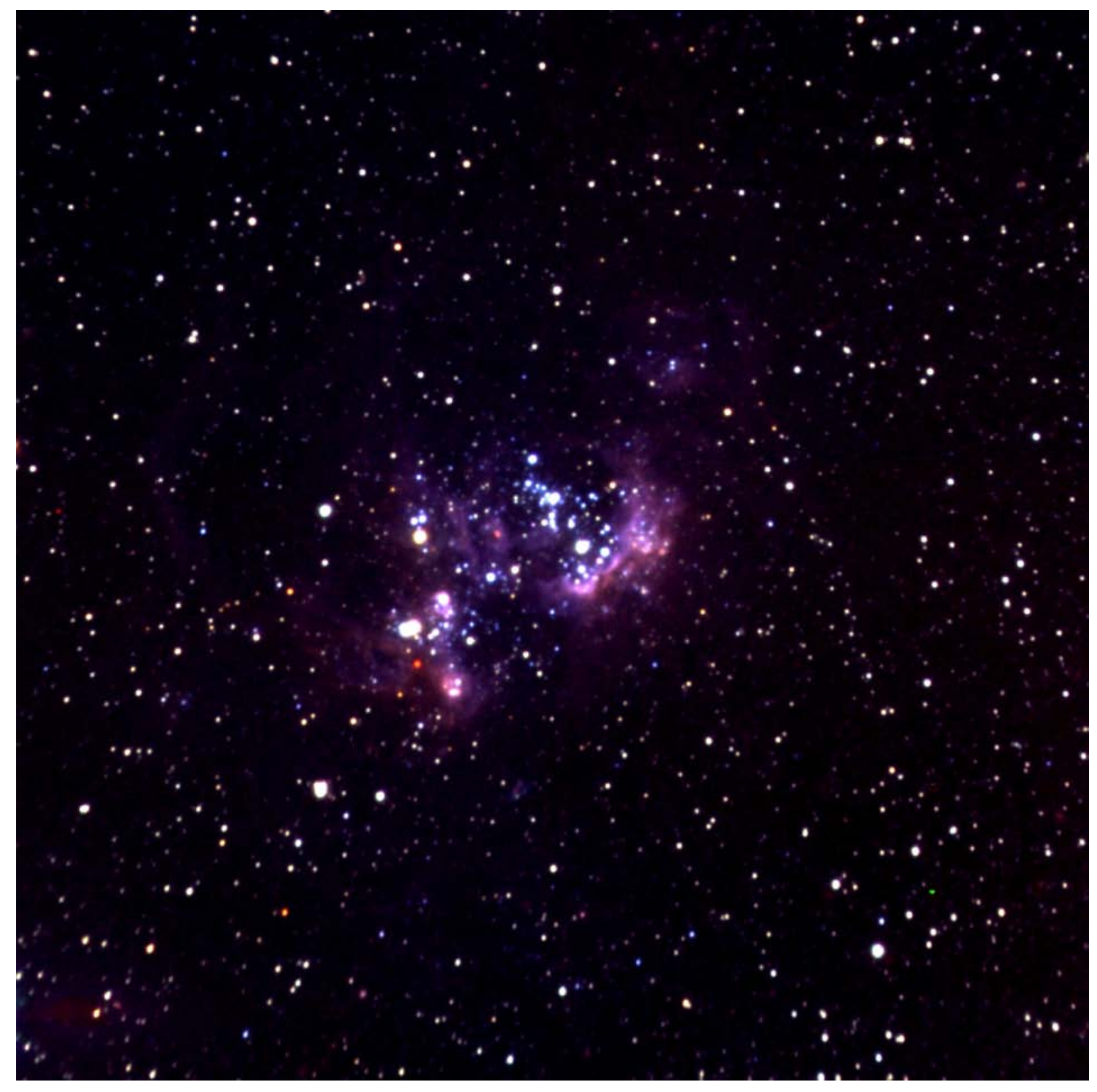




\section{Resumen}

\section{'Individualizando la nueva generación estelar en NGC 604: Estudio fotométrico infrarrojo con Gemini-NIRI'}

El estudio realizado en la presente Tesis de Doctorado se focaliza en la detección y primera caracterización de los objetos individuales que constituyen la nueva generación de estrellas de gran masa de la región HII gigante, NGC 604.

NGC 604 se encuentra ubicada en la galaxia M 33 a 840 kpc de distancia, y es la segunda región HiI gigante más luminosa del Grupo Local, después de 30 Doradus.

El cúmulo central ionizante contiene, al menos, 200 estrellas de tipos espectrales OB y presenta una estructura conocida como "Scale OB Association", caracterizada por una distribución de objetos muy extendida, sin un núcleo central definido. En la población estelar de NGC 604 también se han identificado estrellas tipo Wolf-Rayet, una gigante roja confirmada y varias candidatas y una estrella en la fase de 'Luminous Blue Variable'. La edad estimada para el cúmulo central es 2.5-5 millones de años. En cuanto al medio interestelar de la región, se observa que presenta una estructura muy compleja: regiones con distinto grado de excitación conformando cavidades interconectadas, filamentos y cáscaras en expansión cuya cinemática refleja dicha complejidad. Las nubes moleculares rodean al cúmulo central por la parte sur extendiéndose en esa dirección.

En una región de formación estelar masiva como NGC 604, las fuentes que presentan exceso infrarrojo son objetos rodeados por material circumestelar, entre los cuales se encuentran principalmente objetos estelares masivos jóvenes y, en menor número, estrellas masivas evolucionadas como supergigantes Of, B[e] y estrellas tipo Wolf-Rayet. En los objetos masivos jóvenes (recientemente formados o en proceso de formación) el exceso infrarrojo observado puede ser producido por material circumestelar posiblemente remanente de la nube de gas y polvo originaria que aún no ha sido completamente disipado por el objeto central o por envolturas-discos 
circumestelares de material todavía en acreción. Por consiguiente, las observaciones en el rango del infrarrojo cercano resultan particularmente útiles en el estudio de los objetos masivos en formación.

El trabajo realizado para la presente Tesis Doctoral comprende la reducción y procesamiento de imágenes fotométricas en el infrarrojo cercano y el análisis de los datos obtenidos en el contexto astrofísico. La imágenes utilizadas fueron tomadas con el instrumento NIRI del telescopio Gemini-Norte, con tres filtros de banda ancha $(J, H$ y $K s)$ y tres filtros de banda angosta $(P a \beta$, $B r \gamma$ y $\left.H_{2}\right)$. El campo observado cubre un área de $120^{\prime \prime} \times 120^{\prime \prime}\left(\sim 400 \times 400 \mathrm{pc}^{2}\right.$ a la distancia de M 33). Las condiciones de observación fueron excelentes, siendo el seeing promedio medido en las imágenes de la banda $K s$ de $0.35^{\prime \prime}$.

Las imágenes de banda ancha se utilizaron para detectar los objetos masivos en formación de la región. Para lo cual, sobre dichas imágenes, se realizaron ajustes de fotometría PSF y se obtuvieron las magnitudes JHKs de los objetos del campo. Este proceso resultó muy laborioso y fue realizado con extremado cuidado y detalle, debido principalmente a dos factores: i) las características de las imágenes, dadas por condiciones específicamente instrumentales de NIRI y ii) las características astrofísicas del campo observado, el cual presenta zonas altamente pobladas, con emisión nebular intensa y variable en pequeñas escalas espaciales. Con los datos de las magnitudes $J H K s$, se seleccionaron los objetos pertenecientes a la región que presentan exceso infrarrojo, identificando de este modo, por primera vez en NGC 604, las fuentes individuales candidatas a objetos masivos en formación.

Una vez identificados los objetos con exceso infrarrojo se generó una propuesta para obtener nuevas observaciones con Gemini-NIFS (espectroscopía de campo integrado) con el fin de corroborar la naturaleza de dichas fuentes.

Las imágenes de banda angosta, trazan la emisión nebular, y permitieron caracterizar el medio interestelar en la región, analizando particularmente el medio interestelar en los alrededores de los candidatos a objetos masivos en formación detectados a partir de las imágenes de banda ancha. Las imágenes de banda angosta fueron utilizadas junto con imágenes de $H \alpha$ de HSTWFPC2, para generar cocientes que exhiben la atenuación producida por el polvo en la región. Los mapas obtenidos tienen una alta resolución espacial y sensibilidad. Se estudió la ubicación de los objetos con fotometría JHKs en el campo de NGC 604 en relación a la atenuación en la región y a otras componentes de medio interestelar mapeadas por imágenes en distintos rangos espectrales (líneas de HCN y CO, continuo de radio en $89 \mathrm{GHz}$ y $8.44 \mathrm{GHz}$ y continuo en $8 \mu \mathrm{m}$ ), con lo cual se obtuvo una imagen acabada de la distribución de la población estelar masiva de NGC 604 y, en particular, de las fuentes candidatas a objetos masivos en formación. Además, en las imágenes de $\mathrm{H}_{2}$, se detectaron por primera vez en la región, dos objetos que presentan emisión en dicha banda. La emisión en $H_{2}$ está asociada a eyecciones de materia comúnmente 
observadas en objetos de media y baja masa; sin embargo, las detecciones en objetos de alta masa son poco frecuentes. Estos dos objetos resultan un hallazgo valioso y se requieren nuevas observaciones para estudiar el origen de dicha emisión y la naturaleza de las fuentes centrales.

Por otro lado, los datos de fotometría JHKs fueron utilizados para calcular la fracción total de objetos con exceso infrarrojo en el cúmulo de NGC604, el valor obtenido se evaluó en el contexto de los datos derivados para regiones de formación estelar galácticas. El resultado indica que NGC 604 presenta una fracción de objetos con exceso infrarrojo sustancialmente alta para la edad del cúmulo.

Los resultados obtenidos en función del análisis realizado en el presente estudio han aportado datos nuevos y precisos sobre los objetos individuales que conforman la población estelar masiva más jóven de NGC 604. A nivel global en la región, los datos estudiados permiten armar un escenario coherente con el conocimiento relativo a otras regiones de formación estelar de estrellas de alta masa. Así mismo, los resultados obtenidos también son consistentes con las conclusiones derivadas en estudios previos realizados en NGC 604, de este modo las fuentes que exhiben exceso infrarrojo se encuentran mayoritariamente localizadas en las zonas donde estudios relativos a la componente gaseosa de la región, concluyen que en dichas zonas el material molecular presenta condiciones físicas (alta densidad y temperatura) apropiadas para propiciar y mantener procesos de formación estelar masiva actual. A nivel de objetos individuales, se han detectado cierto número de fuentes cuyas características observadas permiten inferir que son objetos peculiares de gran interés astrofísico y por consiguiente merecen ser observados y estudiados individualmente de manera más profunda y detallada.

El trabajo desarrollado en esta Tesis constituye el primer estudio observacional dedicado a la detección de los miembros individuales de la nueva generación estelar de la región HII gigante NGC 604. 



\section{Nota}

Me hubiera gustado tener la libertad de poder escribir mi Tesis de Doctorado en inglés. Entiendo que siendo la Astronomía una ciencia de carácter internacional existe un idioma común que permite y facilita la participación y comunicación de toda la comunidad astronómica mundial. En la actualidad, es aceptado e indiscutible que dicho idioma es el inglés.

A principios del mes de julio del año 2010 presenté una nota al Decano y a la Comisión de Grado Académico de la Facultad de Ciencias Astronómicas y Geofísicas pidiendo autorización para escribir mi Tesis de Doctorado en inglés. En dicha nota expuse los argumentos racionales que motivaban mi pedido, además la nota iba acompañada por una segunda nota firmada por una considerable cantidad de graduados y doctorados de nuestra Facultad que avalaban el pedido y los motivos. A esta nota siguieron otras notas, así las discusiones llevaron algunos meses y se dieron en una sorprendente variedad de foros y niveles. Desafortunadamente, en el mes de noviembre de 2010, la resolución final de la Comisión, aprobada por el Consejo, fue otorgarme la autorización para escribir sólo el Capítulo 2 en inglés. De modo que eso fue lo que hice y esa es la razón por la cual esta Tesis presenta la extraña particularidad de estar conformada por cinco capítulos en castellano y uno en inglés.

Tengo la certeza, y la esperanza, de que en un futuro no muy lejano esta situación cambie y que cada persona que haya trabajado en su Tesis de Doctorado sea libre de elegir si desea escribir su propio trabajo en inglés (que en esta época es el idioma mundial de la ciencia) o en castellano.

Personalmente, estoy convencida de que el conocimiento cientifíco pertenece a la humanidad y transciende cuestiones de nacionalidades.

C. F. 



\section{Índice general}

Índice de tablas $\quad$ XI

Índice de figuras $\quad$ XIII

1. Introducción $\quad \mathbf{1}$

1.1. Introducción . . . . . . . . . . . . . . . . . . . . . . . . . . . 1

1.2. Observaciones en el infrarrojo cercano . . . . . . . . . . . . . . . . . . . . . . . . . . . . . . . . . . . . .

1.2.1. ¿Por qué observar en el NIR? . . . . . . . . . . . . . . . . . 3

1.2.2. Consideraciones generales sobre observaciones en el NIR . . . . . . . . 4

1.2.3. Carencia de un sistema fotométrico estándar . . . . . . . . . . . . . . 8

1.3. Formación de estrellas de gran masa . . . . . . . . . . . . . . . . . . . . 11

1.4. Formación estelar inducida . . . . . . . . . . . . . . . . . . . . . . . . . . . . 14

1.5. Objetos con exceso IR en regiones de formación estelar . . . . . . . . . . . . . . 15

1.6. Regiones Hil gigantes . . . . . . . . . . . . . . . . . . . . . . . . . . . . . . 21

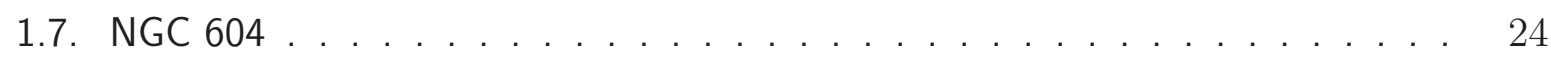

1.7.1. Sobre la componente gaseosa . . . . . . . . . . . . . . . 27

1.7.2. Sobre la componente estelar . . . . . . . . . . . . . . . . . . . . . . . . . 30

1.7.3. Sobre la nueva generación de estrellas . . . . . . . . . . . . . . . . . 32

2. Observational data and data handling 35

2.1. Introduction . . . . . . . . . . . . . . . . . . . . . . 35

2.2. Gemini-NIRI: a brief instrument description . . . . . . . . . . . . . . . . 37

2.3. Observational data: the proposal . . . . . . . . . . . . . . . . . . . 41

2.4. Basic raw image corrections . . . . . . . . . . . . . . . . . . . . . . 46

2.4.1. Vertical striping correction . . . . . . . . . . . . . . . . . 46

2.4.2. Non-linearity correction . . . . . . . . . . . . . . . . . . . . . . . . . 49

2.5. Reduction process: IRAF tasks . . . . . . . . . . . . . . . . . . . 51 
2.5.1. Comments on the image quality . . . . . . . . . . . . 56

2.6. The astrometry . . . . . . . . . . . . . . . . . . . . . . . . . . . . 6 60

2.7. Point spread function photometry . . . . . . . . . . . . . . . . . 63

2.8. The ' $\chi$ problem' . . . . . . . . . . . . . . . . . . . . . . . . . 77

2.9. To the standard system photometry . . . . . . . . . . . . . . . . . . . . . 81

3. Análisis y resultados derivados de los datos de banda ancha 87

3.1. Introducción . . . . . . . . . . . . . . . . . . . . . . . . 87

3.2. La 'región central' y la 'región de campo' de NGC604 f . . . . . . . . . . . . . . 89

3.3. Sobre el error interno de la fotometría . . . . . . . . . . . . . . . . . . . . . . 91

3.4. Sobre la completitud de la fotometría . . . . . . . . . . . . . . . . . . . . . . . 95

3.5. Diagramas color-color y color-magnitud . . . . . . . . . . . . . . . . . . . . 98

3.6. Contaminación por objetos de campo . . . . . . . . . . . . . . . . . . . . . . 101

3.7. Distribución espacial de los objetos con exceso IR . . . . . . . . . . . . . . . . 107

3.8. Fracción de objetos con exceso IR . . . . . . . . . . . . . . . . . . . . . . . . 109

3.9. Objetos individuales estudiados previamente . . . . . . . . . . . . . . . 118

4. Análisis y resultados derivados de los datos de banda angosta 125

4.1. Introducción . . . . . . . . . . . . . . . . . . . . . 125

4.2. Imágenes para el estudio de la componente nebular . . . . . . . . . . . . . . 127

4.2.1. Imágenes de banda angosta de Gemini-NIRI . . . . . . . . . . . . . . . 127

4.2.2. Otras imágenes que mapean la componente nebular . . . . . . . . . . 127

4.3. Mapas de cocientes de imágenes de banda angosta . . . . . . . . . . . . . . . 129

4.3.1. Resta del continuo de las imágenes de banda angosta de Gemini-NIRI:

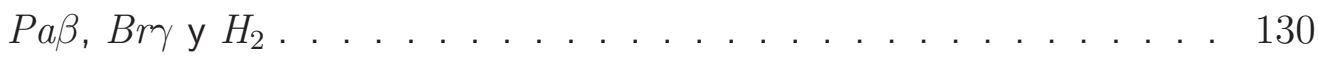

4.3.2. Resta del continuo de la imagen de Ho de HST-WFPC2 . . . . . . . . 135

4.3.3. Cociente de imágenes de Gemini-NIRI y HST-WFPC2 . . . . . . . . . 136

4.3.4. Mapas de extinción . . . . . . . . . . . . . . . . . . . . . . . . 138

4.4. Los objetos con exceso IR en el contexto global de NGC 604 . . . . . . . . . . 140

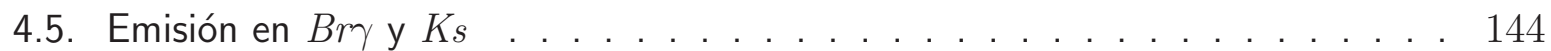

4.6. Objetos con emisión de $H_{2} \quad \ldots \ldots \ldots$. . . . . . . . . . . . . . . . . . . 149

5. Trabajo a futuro 153

5.1. Propuesta presentada para Gemini-NIFS . . . . . . . . . . . . . . . . . . . . . 155

5.2. Futura propuesta para observar las fuentes A y B . . . . . . . . . . . . . 160

5.3. Nueva información obtenida a partir de datos ya existentes . . . . . . . . . . . 160

5.4. Fracción de objetos con exceso IR en GHRs . . . . . . . . . . . . . . . . . . . 161

6. Síntesis de resultados y consideraciones finales 163 
$\begin{array}{ll}\text { A. Glosario } & 167\end{array}$

A.1. Acrónimos y abreviaciones . . . . . . . . . . . . . . . . . . . . . . . 167

$\begin{array}{ll}\text { Bibliografía } & 173\end{array}$

$\begin{array}{ll}\text { Agradecimientos } & 179\end{array}$ 


\section{Índice de tablas}

1.1. Valores del brillo superficial producido por la emisión de fondo del cielo . . . . 8

1.2. 'Estrellas de baja masa', 'estrellas de masa intermedia' y 'estrellas de gran masa' 12

1.3. Parámetros de regiones HiI galácticas y GHRs . . . . . . . . . . . . . . . . . 21

2.1. Cameras available at Gemini-NIRI . . . . . . . . . . . . . . . . . . . . 37

2.2. NIRl's detector main characteristics . . . . . . . . . . . . . . . . . . . . . . . . 38

2.3. Broad-band and narrow-band filters main characteristics . . . . . . . . . . . . 43

2.4. Observations' general information . . . . . . . . . . . . . . . . . . . . . . 45

2.5. Results of a basic statistics over the whole image area . . . . . . . . . . . . . 60

2.6. Image headers values required by the DAOPHOT's tasks . . . . . . . . . . . 65

2.7. Aperture correction values and transformation constants from instrumental magnitudes to the MKO system . . . . . . . . . . . . . . . . . . . . . . . . . . 84

2.8. Excerpt of the final photometry table . . . . . . . . . . . . . . . 86

3.1. Resultados de los conteos de objetos con exceso IR por regiones en NGC 604 . 116

3.2. Objetos previamente estudiados en NGC 604 . . . . . . . . . . . . . . . . . . 121

4.1. Valores utilizados para la resta de continuo de Gemini-NIRI . . . . . . . . . . 133 


\section{Índice de figuras}

1.1. Modelos de curvas de extinción producidas por el polvo . . . . . . . . . . . . 4

1.2. Curvas de transmisión atmosférica para Mauna Kea (Hawaií) . . . . . . . . . 5

1.3. Espectro de emisión de airglow en las bandas JHK . . . . . . . . . . . . . . . 6

1.4. Fuentes de emisión de fondo en el infrarrojo . . . . . . . . . . . . . . . . . . 7

1.5. Sistema de filtros MKO-NIR (las bandas $J, H, K_{s}, L^{\prime}$ y $M^{\prime}$ ) . . . . . . . . . 9

1.6. Conjuntos de filtros usados en el NIR . . . . . . . . . . . . . . . . . . . . . . . . . 10

1.7. Diagrama CM, distribución de MYSOs y otros objetos de masa intermedia-alta 17

1.8. Espectros en la banda $K$ de estrellas masivas jóvenes . . . . . . . . . . . . . . . 18

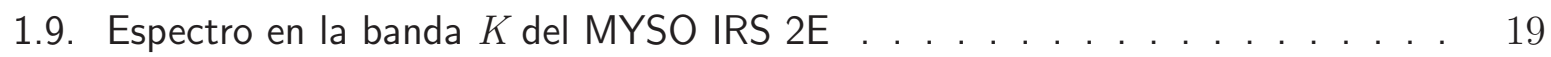

1.10. Esquema de un modelo de disco de acreción alrededor de un MYSO . . . . . . 20

1.11. Espectros en la banda $K$ de estrellas masivas evolucionadas . . . . . . . . . . . 20

1.12. R136,la nebulosa de la Tarántula y NGC $604 \ldots$. . . . . . . . . . . . . . . . . . . 25

1.13. M33 y NGC604 . . . . . . . . . . . . . . . . . . . . . . . . . . . . . . . . . . 26

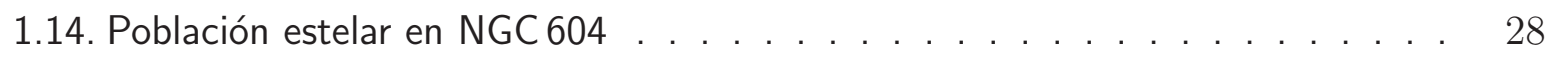

1.15. Emisión de CO y rayos X en NGC $604 \ldots$. . . . . . . . . . . . . . . . . . . . . 30

1.16. Emisión en continuo de radio a $8.44 \mathrm{GHz} \ldots \ldots$. . . . . . . . . . . . . . . 31

2.1. First series $K s$ image exhibiting the dark current pattern . . . . . . . . . . . . 40

2.2. H filter flat image . . . . . . . . . . . . . . . . . . . . . . . . . . . 42

2.3. Filter set transmission curves . . . . . . . . . . . . . . . . . . . . . . . . . . . . 43

2.4. Sky, science fields position, and dithering pattern . . . . . . . . . . . . . . 44

2.5. Vertical striping correction . . . . . . . . . . . . . . . . . . . . . . . 47

2.6. Vertical striping pattern . . . . . . . . . . . . . . . . . . . . . . . . . . . . 48

2.7. Segment count statistics . . . . . . . . . . . . . . . . . . . . . . . . . . . . . . . . . 49

2.8. Count rates histograms for our images in all the bands . . . . . . . . . . . . . 50

2.9. Histograms of pixel values distribution before and after the non-linearity correction 51

2.10. Linearity correction coefficients as a function of exposure time . . . . . . . . . 52 
2.11. Complete $K s$-band image series . . . . . . . . . . . . . . . . . . 57

2.12. Combined $K s$ images generated with all the images and with the 'clean' images 59

2.13. Line profiles of columns in different $K s$ images . . . . . . . . . . . . . . . . . . 59

2.14. Comparison of magnitudes obtained from different $K s$ images . . . . . . . . . . 61

2.15. Images where the features produced by the 'movement' are evident . . . . . . 62

2.16. Distribution of the 55 GSC's point sources used for the astrometry . . . . . . 64

2.17. Spatial object distribution of the final PSF star list for filter $J \ldots$. . . . . . . . 70

2.18. Zoomed area of the subtracted $H$-band image at different stages of the PSF model construction . . . . . . . . . . . . . . . . . . . . 73

2.19. Different views for the final PSF model for the $J$ filter . . . . . . . . . . . . . 74

2.20. Original and subtracted stars image for comparison . . . . . . . . . . . . . . 76

2.21. Sharpness values distribution with the magnitudes for the JHKs bands . . . . 78

2.22. $\chi$ values' distribution with the magnitudes for the JHKs bands . . . . . . . . 78

2.23. $\chi$ values distribution with the magnitudes resulted from run sc allstar on single

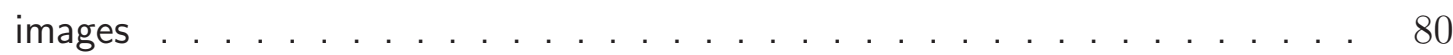

2.24. Selected field stars for aperture correction . . . . . . . . . . . . . . . . . . . . . 82

2.25. Growth curve models for standard and field stars. . . . . . . . . . . . . . . . . 83

2.26. Comparison between our photometric results and Cioni et al. (2008) for the set of stars in common . . . . . . . . . . . . . . . . . . . . . . 85

3.1. Histogramas del número de objetos por intervalo de RA y Dec . . . . . . . . . 90

3.2. Límite de la regioón central y la región de campo . . . . . . . . . . . . . . . . 92

3.3. Estrellas ficticias agregadas sobre la imagen de la banda J con . . . . . . . . . 94

3.4. Diagramas $\operatorname{mag}_{V}-\operatorname{mag}_{P S F}$ vs. $\operatorname{mag}_{V}$ para las bandas JHKs . . . . . . . . . . 96

3.5. Función de brillo para las bandas JHKs para la región central y la región de campo 97

3.6. Distribución de errores en función de las magnitudes . . . . . . . . . . . . . . 98

3.7. Diagrama color-color de los objetos pertenecientes a la región central . . . . . 102

3.8. Diagrama color-magnitud de los objetos pertenecientes a la región central . . . 103

3.9. Diagramas CC y CM de los objetos pertenecientes a la región de campo . . . . 104

3.10. Diagramas color-color (en forma de diagramas de densidad) . . . . . . . . . . 106

3.11. Distribución de los objetos de la región central en el campo de NGC 604 . . . . 110

3.12. Distribución de objetos con exceso IR en la región central . . . . . . . . . . . 111

3.13. Distribución de CO de alta densidad y temperatura . . . . . . . . . . . . . . . 111

3.14. Diagrama de $\eta_{I R}$ vs. edad del cúmulo para distintas regiones de formación estelar112

3.15. Fracción de objetos con exceso IR por regiones . . . . . . . . . . . . . . . 115

3.16. Diagrama de $\eta_{I R}$ vs. edad del cúmulo para distintas regiones de NGC 604 . . . 116

3.17. Objetos conocidos en el campo de NGC 604 . . . . . . . . . . . . . . . . . . . 119

3.18. Diagramas color-color y color-magnitud de los conocidos en el campo de NGC 604120

4.1. Curvas de transmisión de los filtros de Gemini-NIRI . . . . . . . . . . . . . . . 128 
4.2. Curvas de extinción para distintos modelos de composición del polvo . . . . . 130

4.3. Imágenes de banda angosta originales y luego de la resta de continuo . . . . . . 134

4.4. Objetos mal restados en las imágenes de banda angosta . . . . . . . . . . . . 135

4.5. Imágenes de $\mathrm{H} \alpha$ original y luego de la resta de continuo . . . . . . . . . . . . . 137

4.6. Mapas de extinción obtenidos a partir de los cocientes de imágenes . . . . . . . 139

4.7. En seis paneles, el mapa de extinción $B r \gamma / H \alpha$ y diferentes componentes de medio interestelar . . . . . . . . . . . . . . . . . . . . . . . . . . . . . . 142

4.8. Contornos de CO en NGC 604 y zoom de la región con el máximo de HCN . . 143

4.9. Diagrama CC para RSG, un cuerpo negro y emisión puramente nebular . . . . 145

4.10. Diagrama CC para los objetos con emisión $B r \gamma$ y gráfico $(K s-B r \gamma)$ vs. $K s \quad$. 148

4.11. Distintos modelos de SED para Lupus 3MMS . . . . . . . . . . . . . . . . . 149

4.12. Objetos detectados con emisión en $H_{2} \quad \ldots \ldots \ldots \ldots \ldots$

4.13. Área de los objetos con emisión en $H_{2}$ de imágenes en distintas bandas . . . . 151

5.1. Campos seleccionados para ser observados con Gemini-NIFS . . . . . . . . . . 156

5.2. Configuración final para propuesta de observación con Gemini-NIFS . . . . . . 158 



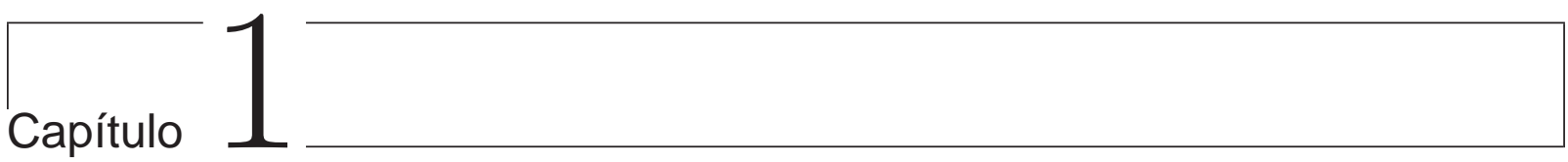

\section{Introducción}

\subsection{Introducción}

El estudio realizado en esta Tesis tiene como objetivo principal la detección de las fuentes individuales candidatas a objetos estelares jóvenes de gran masa $\left(\mathrm{MYSOs}^{1}\right)$ que conforman la nueva generación estelar en NGC 604, una de las regiones HII gigantes (GHR²) más importantes del Grupo Local. Con este fin se han utilizado observaciones fotométricas en el rango del infrarrojo cercano $\left(\mathrm{NIR}^{3}\right)$ tomadas con el instrumento NIRI del telescopio Gemini-Norte.

Este primer Capítulo de la Tesis presenta una breve introducción e integración de los principales temas involucrados en el estudio realizado y comprende la siguientes Secciones: - Observaciones en el infrarrojo cercano: se sintetizan los fundamentos básicos de las observaciones en el rango espectral del infrarrojo (IR) y los motivos que justifican la elección de observaciones en dicho rango espectral para llevar a cabo el presente estudio; • Formación de estrellas de gran masa: se presenta una síntesis general sobre formación de estrellas masivas; - Formación estelar inducida: se presenta una síntesis general sobre formación estelar inducida; • Objetos con exceso IR en regiones de formación estelar: se describen las características de la emisión de distintos objetos que presentan exceso IR en las regiones de formación estelar masiva; - Regiones HII gigantes: se realiza una síntesis global sobre las GHRs y en particular sobre NGC 604 y 30 Dor, las dos GHRs más importantes del Grupo Local; • NGC 604: se presenta un compendio de los conocimientos generales relativos a NGC 604, obtenidos en distintos estudios previos disponibles en la literatura.

\footnotetext{
${ }^{1}$ MYSO: del acrónimo en inglés de 'Massive Young Stellar Object' (objeto estelar masivo joven).

${ }^{2}$ GHR: del acrónimo en inglés de 'Giant Hir Region (región Hiı gigante).

${ }^{3} \mathrm{NIR}$ : del acrónimo en inglés de 'Near Infrared' (infrarrojo cercano).
} 



\subsection{Observaciones en el infrarrojo cercano}

\subsection{1. ¿Por qué observar en el NIR?}

El NIR abarca el rango de longitudes de onda comprendido entre $\lambda \sim 0.7-5.0 \mu \mathrm{m}^{4}$, el cual se corresponde con la emisión de cuerpo negro a temperaturas entre $\mathrm{T} \sim 800-5500 \mathrm{~K}$. Las observaciones en el rango del NIR permiten obtener una resolución espacial comparable a la obtenida en el óptico y cuentan con la ventaja de que la radiación en las longitudes de onda que abarca, es significativamente menos afectada por la extinción (dispersión y absorción) del polvo presente en el medio interestelar $\left(\mathrm{IMS}^{5}\right)$. La relación entre la absorción en el óptico, en la banda $\mathrm{V}$, y en el NIR, en la banda $\mathrm{K}$, es $\mathrm{A}_{K}=0.112 \mathrm{~A}_{V}$ (Rieke \& Lebofsky, 1985). En la Figura 1.1 se muestran una serie de curvas de extinción empíricas calculadas usando la parametrización de Fitzpatrick (1999) para distintos valores de $\mathrm{R}_{V}{ }^{6}$ en nubes difusas. En dicha figura se observa que las curvas de extinción muestran poca variación con $\mathrm{R}_{V}$ en el IR $\mathrm{y}$, en particular entre $\lambda=0.7-8.0 \mu \mathrm{m}$, la curva de extinción parece ser prácticamente independiente de $\mathrm{R}_{V}$, cabe aclarar que este comportamiento es válido en el caso de nubes difusas pero no para nubes más densas (Draine, 2003).

Entre $\lambda=0.9-5 \mu \mathrm{m}$, la curva de extinción se puede aproximar con una ley de potencias de la forma $\mathrm{A}_{\lambda} \propto \lambda^{\beta}$, donde $\beta$ adopta un valor levemente diferente según los distintos estudios: $\beta \sim 1.61$ (Rieke \& Lebofsky, 1985), $\beta \sim 1.75$ (Draine, 1989), $\beta \sim 1.8$ (Martin \& Whittet, 1990), $\beta \sim 1.70$ (Bertoldi et al., 1999; Rosenthal et al., 2000).

Las estrellas en formación se encuentran en ambientes de gas molecular y polvo, generalmente rodeadas por su propia envoltura de material circumestelar todavía en acreción o por material remanente de la nube de gas y polvo originaria que aún no ha sido completamente disipado por el objeto central. En consecuencia, el NIR constituye el rango de longitudes de onda óptimo para detectar objetos inmersos en el medio ambiente característico de las regiones de formación estelar. Por otro lado, la alta sensibilidad y resolución espacial alcanzada actualmente por los detectores en el NIR ${ }^{7}$ permiten la detección y resolución de objetos individuales en regiones de formación estelar masivas extragalácticas, con zonas densamente pobladas y emisión-absorción de fondo variable. Este es justamente el escenario que presenta la región de NGC 604para la cual, debido a la distancia, $1^{\prime \prime}$ equivale a 4.1 pc.

\footnotetext{
${ }^{4} \mathrm{El}$ rango del infrarrojo se divide convencionalmente en infrarrojo cercano (NIR: de 0.7 a $5 \mu \mathrm{m}$ ), infrarrojo medio (MIR: de 5 a $25 \mu \mathrm{m}$ ) y el infrarrojo lejano (FIR: de 25 a $350 \mu \mathrm{n}$ ).

${ }^{5} \mathrm{IMS}$ : del acrónimo en inglés de 'Interstellar Medium' (medio interestelar).

${ }^{6} \mathrm{R}_{V}$ es el 'cociente de absorción selectiva' y se define como: $\mathrm{R}_{V}=\frac{A_{V}}{\left(A_{B}-A_{V}\right)}=\frac{A_{V}}{E_{(B-V)}}$.

${ }^{7} \mathrm{El}$ ancho a potencia mitad, medido sobre las estrellas de las imágenes de la banda $K s$ obtenidas con Gemini-NIRI para el presente estudio, es de $\sim 0.35^{\prime \prime}$ y los objetos más débiles detectados llegan a $K s \sim 24$ mag.
} 


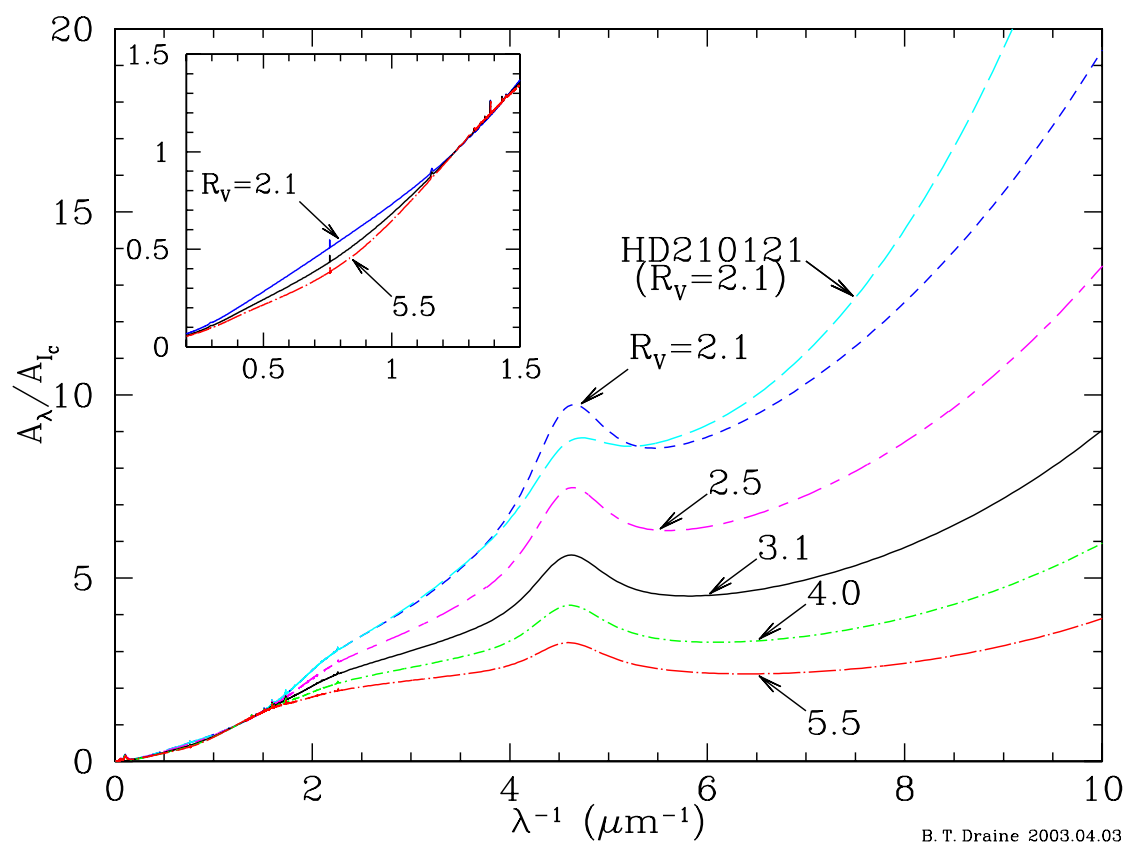

Figura 1.1: Modelos de distintas curvas de extinción producidas por el polvo presente en nubes difusas de medio interestelar, considerando diferentes valores para $R_{V}$. Gráfico tomado de Draine (2003).

\subsubsection{Consideraciones generales sobre observaciones en el NIR}

\section{Absorción atmosférica en el NIR}

Las principales moléculas presentes en la atmósfera terrestre que generan bandas de absorción importantes en el NIR son:

- $\mathrm{H}_{2} \mathrm{O}$ : en $\lambda \lambda 0.94,1.13,1.37,1.87,2.7,3.2,6.3$ y $\lambda>16 \mu \mathrm{m}$

- $\mathrm{CO}_{2}$ : en $\lambda \lambda 2.0,4.3,15 \mu \mathrm{m}$

- $\mathrm{N}_{2} \mathrm{O}$ : en $\lambda 4.5 \mu \mathrm{m}$

- $\mathrm{CH}_{4} \mathrm{O}$ : en $\lambda \lambda$ 3.3, $7.7 \mu \mathrm{m}$

- $\mathrm{N}_{2} \mathrm{O}$ y $\mathrm{O}_{3}$

Estas moléculas se encuentran en la atmósfera mezcladas de manera inhomogénea y su proporción presenta variaciones tanto espaciales como temporales dependiendo principalmente de la altura y la temperatura. La molécula que causa la mayor absorción atmosférica es la de $\mathrm{H}_{2} \mathrm{O}$, seguida por la de $\mathrm{CO}_{2}$.

En la Figura 1.2 se muestra la curva de transparencia atmosférica de 0.9 a $6.0 \mu$ m medida en Mauna Kea (Hawaií), donde se encuentra emplazado el telescopio Gemini-Norte. La altitud del sitio es de $4.2 \mathrm{~km}$ y la masa de aire correspondiente a la medición es de 1.15. Las líneas horizontales representan la posición de los filtros en relación a las ventanas de transmisión 


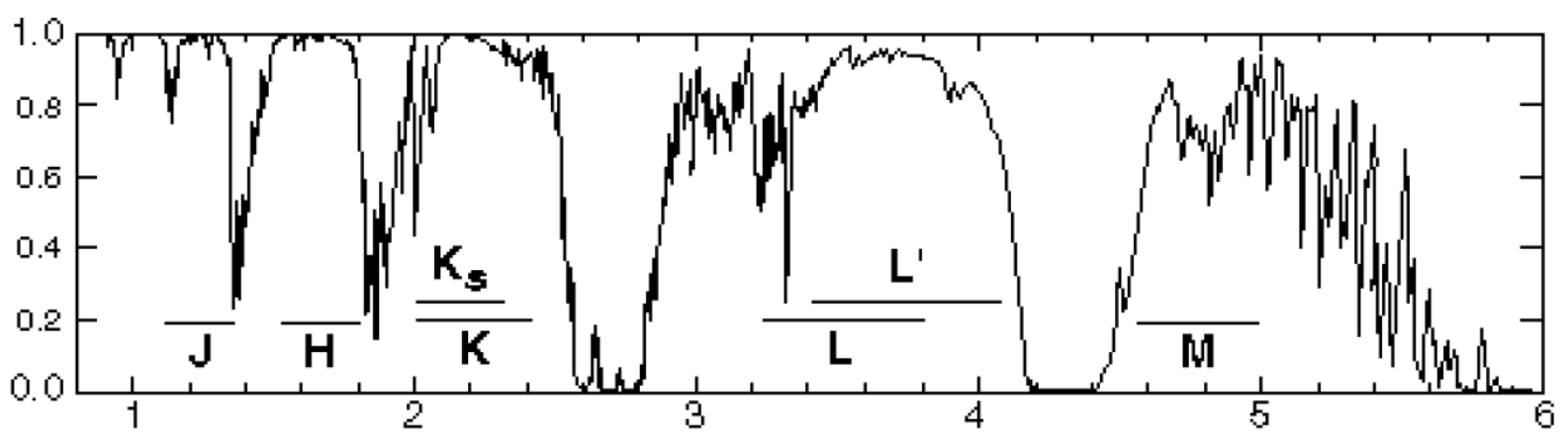

Figura 1.2: Curvas de transmisión atmosférica para Mauna Kea (Hawaií). El eje horizontal corresponde a las longitudes de onda en unidades de $\mu m$, el eje vertical corresponde a la transmisión normalizada.

atmosférica. En dicho gráfico se observa que la transmisión de los filtros puede verse modificada dependiendo de la absorción atmosférica la cual, como se ha mencionado previamente, presenta variaciones espaciales y temporales (Tokunaga, 2000).

\section{Emisión de fondo en el NIR}

Un aspecto importante a considerar en las observaciones realizadas en el rango del IR es la emisión de fondo. La emisión de fondo el para el NIR $(\lambda \sim 0.7-5.0 \mu \mathrm{m})$ se encuentra fundamentalmente dominada por dispersión Rayleigh ${ }^{8}$ de la luz de la luna y las estrellas (fundamentalmente para $\lambda \lesssim 2 \mu \mathrm{m}$ ) y una gran cantidad de líneas de emisión de $\mathrm{OH}$ (conocidas como 'airglow'), originadas en la atmósfera terrestre. El airglow, radiado principalmente por niveles excitados del radical hidroxilo $\left(\mathrm{OH}^{-}\right)$, constituye la fuente dominante de la emisión de fondo en los filtros de banda ancha $J, H$ y $K$. La Figura 1.3, tomada de Glass (1999), muestra en detalle la emisión de airglow en las bandas $J$ (panel superior), $H$ (panel central) y $K$ (panel inferior).

La Figura 1.4, que se extiende más allá del rango del IR $(\lambda \gtrsim 350 \mu \mathrm{m})$, hasta el rango submilimétrico del espectro, muestra en el panel superior la transmisión atmosférica terrestre a distintas alturas: a $4.2 \mathrm{~km}$ (Mauna Kea), a $14 \mathrm{~km}$ y a $28 \mathrm{~km}$. En el panel inferior se exhiben distintas fuentes de emisión de fondo donde: $\mathrm{OH}$ es el airglow producido por el $\mathrm{OH}^{-}$, GBT es la radiación térmica del telescopio (considerado como un cuerpo negro a $\sim 273 \mathrm{~K}$ ), ZSL es la dispersión de la luz zodiacal en el polo de la eclíptica, ZE representa la emisión zodiacal de polvo interplanetario, GBE la emisión de fondo del polvo interestelar en el plano de la galaxia, SEP la emisión del polo sur de la eclíptica (medida por el Cosmic Background Explorer (COBE)) y CBR es la radiación cósmica de fondo (radiación de cuerpo negro a $\mathrm{T} \sim 2.73 \mathrm{~K}$ ).

\footnotetext{
${ }^{8}$ La dispersión Rayleigh se puede expresar matemáticamente como $\mathrm{A}_{\lambda} \propto \lambda^{-4}$.
} 

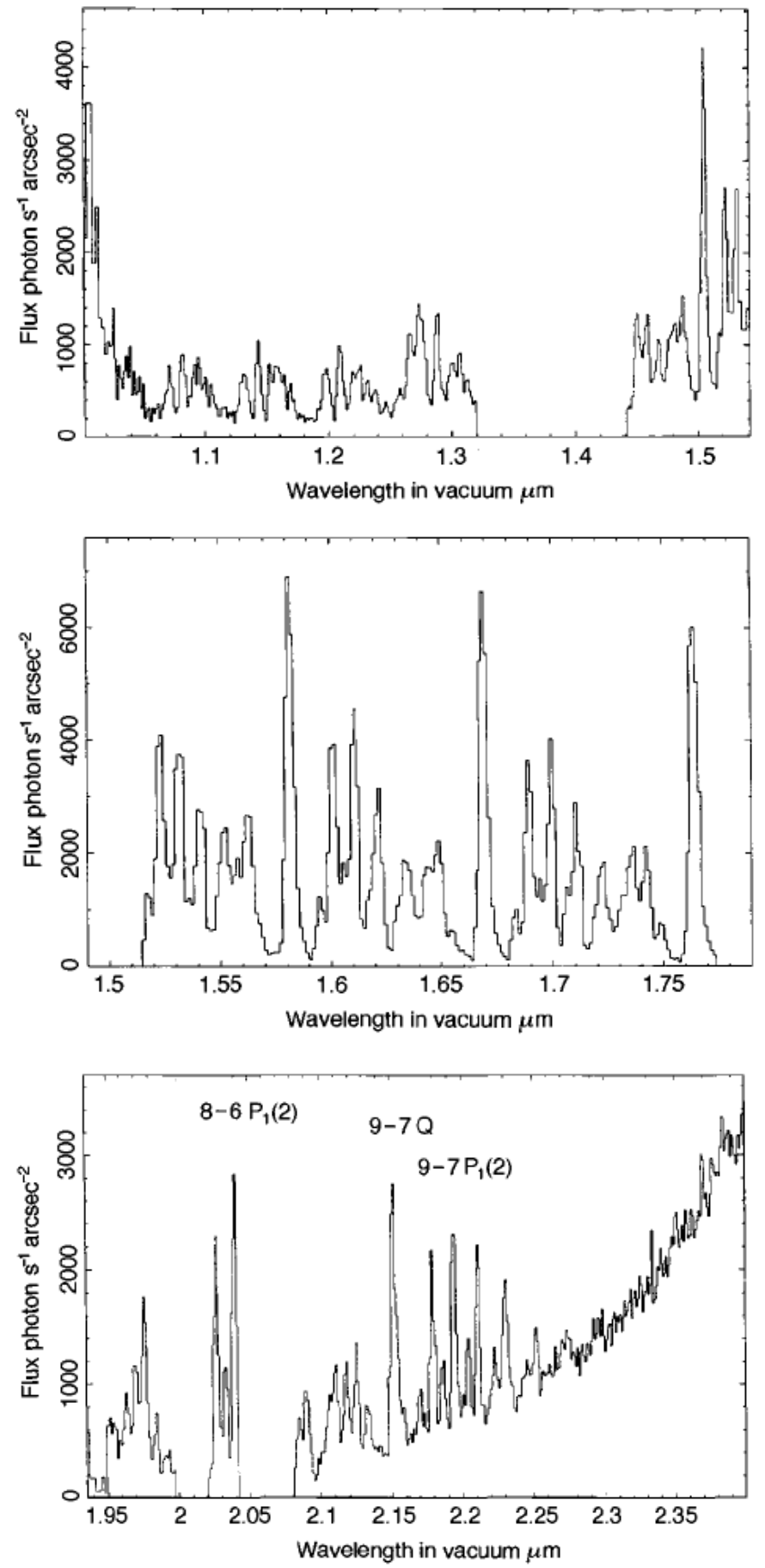

Figura 1.3: Espectro de emisión del airglow en las bandas $J$ (panel superior), $H$ (panel central) y K (panel inferior). Imágenes tomadas de Glass (1999). 


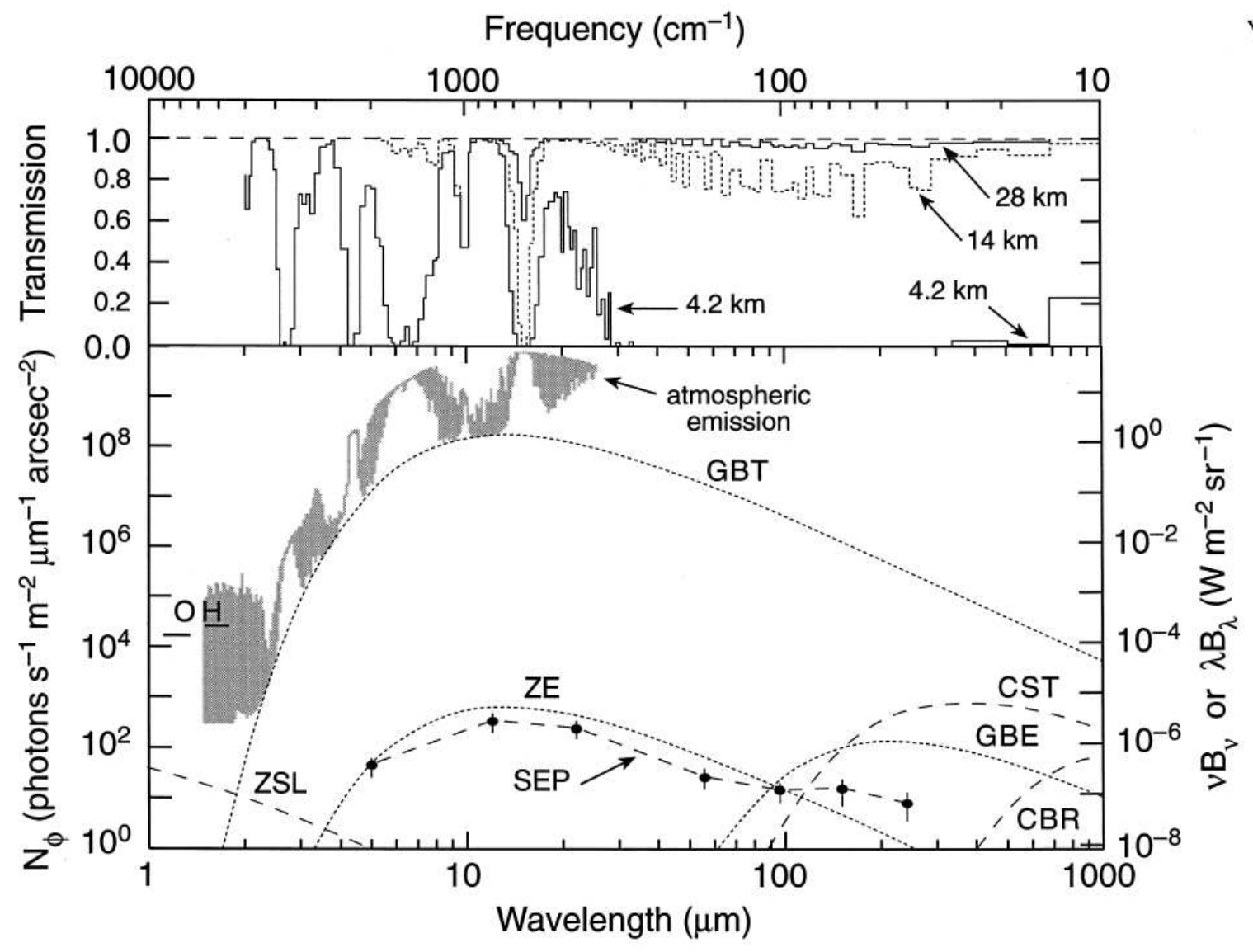

Figura 1.4: En el panel superior se muestra transmisión atmosférica terrestre medida a distintas alturas: a $4.2 \mathrm{~km}$ (Mauna Kea), a $14 \mathrm{~km}$ y a $28 \mathrm{~km}$. En el panel inferior se exhiben distintas fuentes de emisión de fondo donde: $\mathrm{OH}$ es el airglow producido por el $\mathrm{OH}^{-}$, GBT es la radiación térmica del telescopio (considerado como un cuerpo negro a $273 \mathrm{~K}$ ), ZSL es la dispersión de la luz zodiacal en el polo de la eclíptica, ZE representa la emisión zodiacal de polvo interplanetario, GBE la emisión de fondo del polvo interestelar en el plano de la galaxia, SEP la emisión del polo sur de la eclíptica (medida por el Cosmic Background Explorer (COBE)) y CBR es la radiación cósmica de fondo (radiación de cuerpo negro a T $2.73 \mathrm{~K}$ ). Figura tomada de Tokunaga (2000). 


\begin{tabular}{cccc}
\hline Banda & $\begin{array}{c}\lambda \\
(\mu \mathrm{m})\end{array}$ & $\begin{array}{c}\Delta \lambda \\
(\mu \mathrm{m})\end{array}$ & $\begin{array}{c}\text { Brillo superficial } \\
\left(\mathrm{mag} \operatorname{arcsec}^{-2}\right)\end{array}$ \\
\hline $\mathrm{J}$ & 1.26 & 0.31 & 15.9 \\
$\mathrm{H}$ & 1.62 & 0.28 & 13.4 \\
$K s$ & 2.15 & 0.35 & 14.1 \\
$\mathrm{~K}$ & 2.21 & 0.39 & 13.7 \\
\hline
\end{tabular}

Tabla 1.1: Valores de brillo superficial producido por la emisión de fondo del cielo en las bandas $J$, H, Ks y K para un telescopio terrestre de 3.0-m. Se ha considerado la emisión del cielo más la del instrumental para el cual se consideró una emisividad del $7 \%$.

En la Tabla 1.1 se listan, como referencia, los valores de brillo superficial producido por la emisión de fondo en las bandas $J, H, K s$ y $K$ para un telescopio terrestre de 3.0-m. Se han incluido la emisión del cielo y emisión del instrumental para el cual se consideró una emisividad del $7 \%$ (Glass, 1999).

Debido a que la emisión de fondo del cielo en el NIR es intensa y variable tanto espacial como temporalmente, las observaciones en el NIR requieren tomar alternadamente imágenes en el campo de ciencia seguidas de imágenes en un campo de 'cielo' (el campo de cielo debe ser muy cercano al campo de ciencia y lo menos poblado posible). Luego se combinan las imágenes tomadas en el campo de cielo para generar una imagen final de cielo que se usará para sustraer la emisión de fondo de cada una de las imágenes de ciencia. Este procedimiento se encuentra detalladamente explicado en el Capítulo 2.

\subsubsection{Carencia de un sistema fotométrico estándar}

Los estudios astronómicos en el rango espectral del infrarrojo comenzaron a mediados de los años 60. Los filtros utilizados en los primeros trabajos con observaciones en el NIR, realizados principalmente por Harold Johnson y colaboradores (Johnson, 1965, 1966; Johnson et al., 1966, 1968) eran extremadamente anchos, de modo que las bandas de absorción atmosférica definían la transmisión efectiva de los filtros. En la Figura 1.5, se muestran, en línea de puntos, la transmisión de los filtros utilizados por Johnson y colaboradores superimpuestos sobre las curvas de trasmisión atmosférica, las curvas continuas gruesas representan los perfiles de transmisión de los filtros del sistema de Mauna Kea Observatories (MKO), del cual se hablará a continuación. El principal problema de un conjunto de filtros así definido es que, como se mencionó en las Secciones precedentes, las condiciones atmosféricas varían espacial y temporalmente con lo cual resulta difícil repetir las condiciones fotométricas de las observaciones y, por consiguiente, es imposible realizar fehacientemente comparaciones entre los resultados obtenidos de distintas observaciones. La situación óptima es contar con un sistema de filtros en el que las bandas 

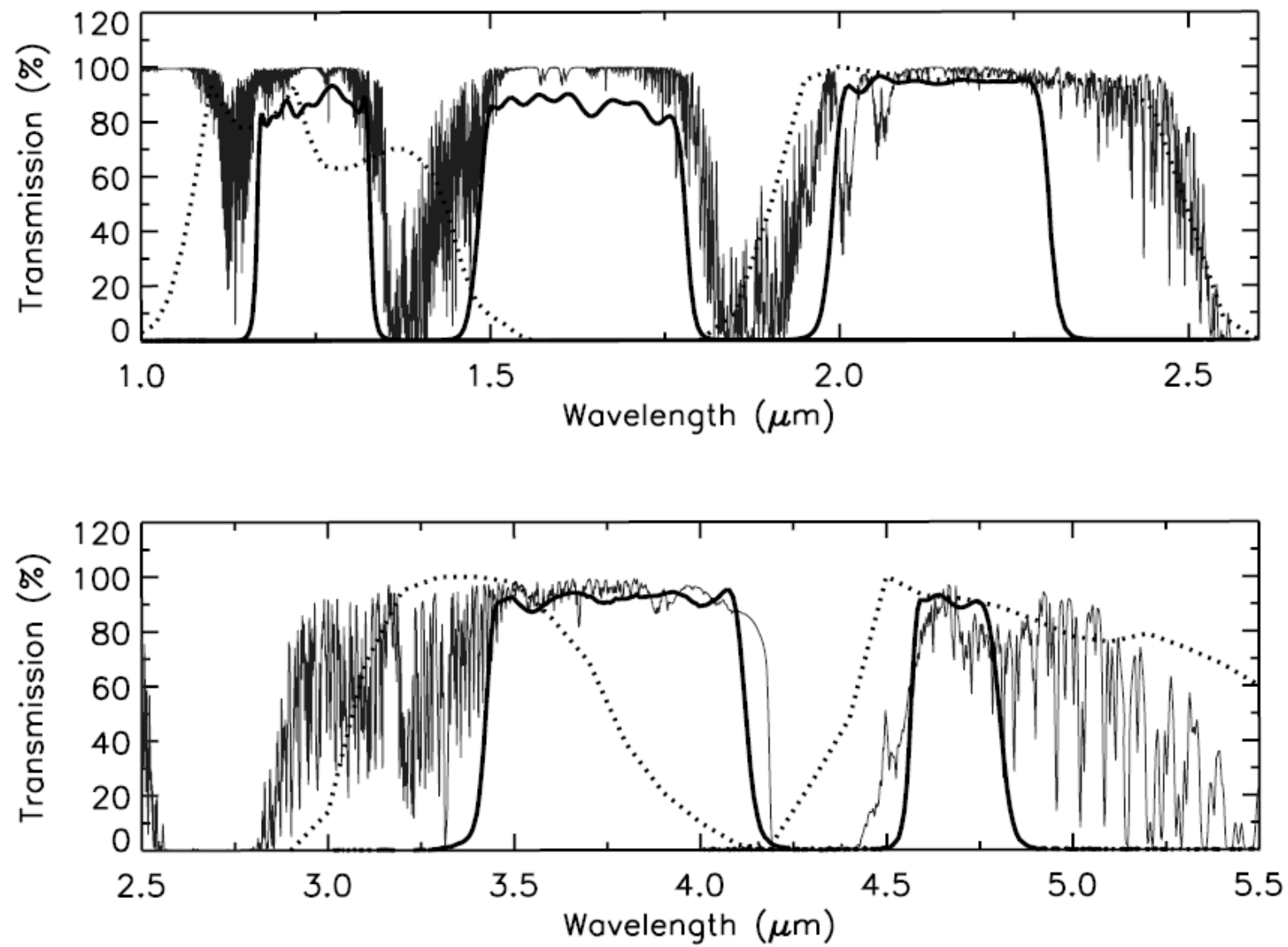

Figura 1.5: Sistema de filtros $M K O-N I R$ (las bandas $J, H, K_{s}, L^{\prime}$ y $M^{\prime}$ ) en línea continua, la línea de puntos muestra, a modo comparativo, uno de los primeros conjuntos de filtros utilizados en el NIR por Johnson en el estudio Johnson (1965). Las ventanas de transmisión atmosférica está graficadas en línea continua fina. La imagen fue tomada de Tokunaga 63 Vacca, $200 \%$.

fotométricas estén definidas únicamente por los perfiles de transmisión de los filtros. Dado que, en principio, las propiedades de los filtros pueden ser controladas en el proceso de fabricación de los mismos, un conjunto de filtros así definido es fácilmente reproducible y distribuible en muchos observatorios.

En los años 80, junto con el avance en la tecnología de los detectores infrarrojos, hubo una gran proliferación de diferentes conjuntos de filtros utilizados en los distintos telescopios, y aún no se ha llegado a una unificación entre los sistemas de filtros. Actualmente existe una gran variedad de sistemas fotométricos distintos, y en muchos casos incluso se utiliza el mismo nombre para filtros que, si bien están definidos en un rango de longitudes de onda similar, tienen un perfil de transmisión distinto. En la Figura 1.6 se muestran las curvas de transmisión de los filtros $J, H$ y $K$ para los distintos sistemas utilizados en la actualidad, la línea de trazos 


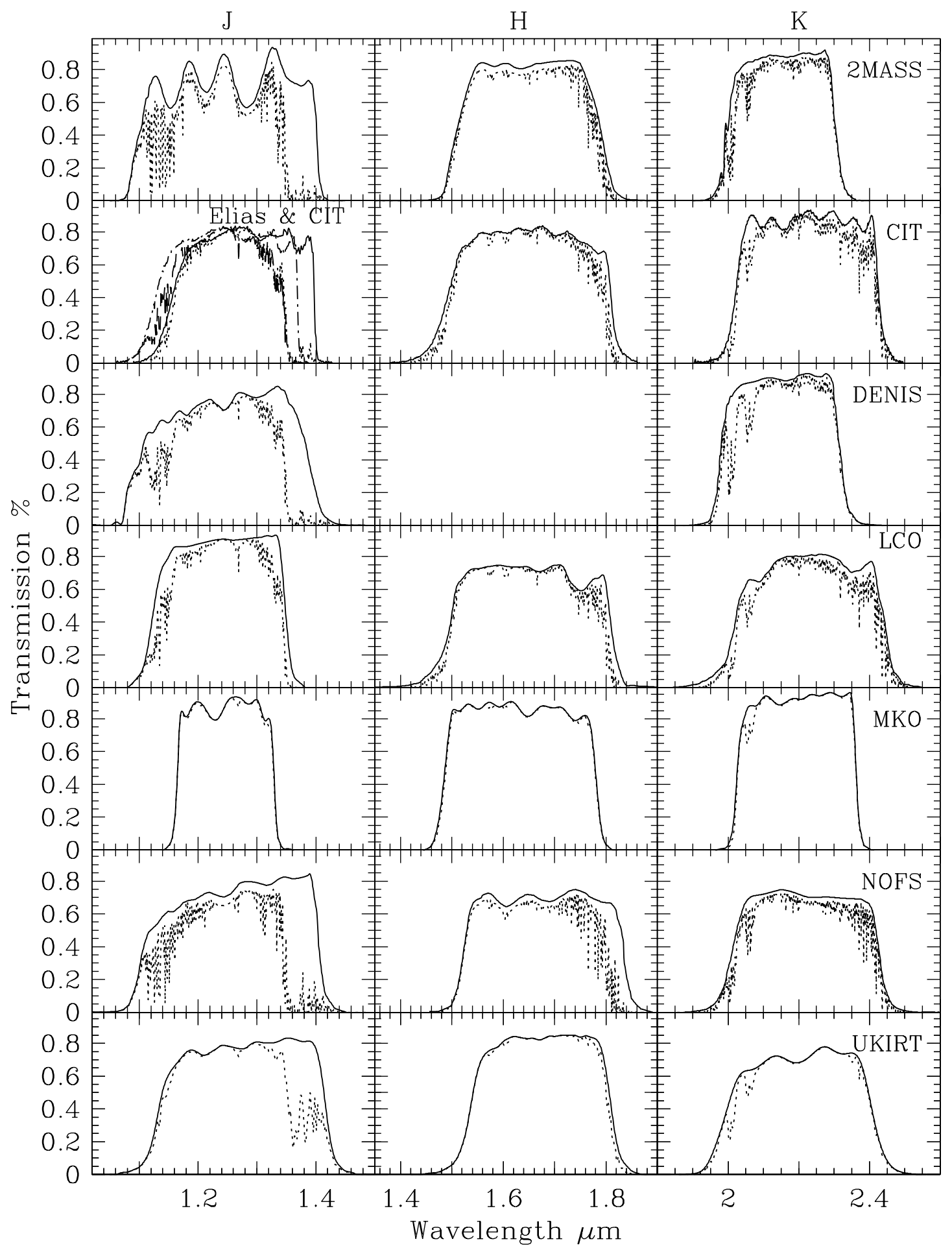

Figura 1.6: Conjuntos de filtros comúnmente usados en el NIR. Las líneas continuas representan los sistemas fotométricos de 2MASS: Two Micron All Sky Survey, CIT: California Institute of Technology, DENIS: Deep Near Infrared Survey, LCO: Las Campanas Observatory, MKO: Mauna Kea Observatory, NOFS: Naval Observatory Flagstaff Station y UKIRT: United Kingdom Infrared Telescope. Las líneas de trazos corresponden a la transmisión atmosférica en cada banda. Imagen tomada de Stephens 85 Leggett (2004). 
representa las ventanas de transmisión atmosférica en dichas bandas. Esta figura fue tomada del trabajo de Stephens \& Leggett (2004).

El problema de utilizar un gran número de sistemas fotométricos distintos radica en la dificultad de comparar resultados obtenidos mediante observaciones en los distintos sistemas. Si bien es posible definir ecuaciones de transformación entre los distintos sistemas fotométricos; existen efectos sistemáticos inherentes a la transformación entre sistemas fotométricos y, por otro lado, las transformaciones de colores son aplicables en un rango de colores limitado.

En los últimos años se ha tratado de promover la utilización del conjunto de filtros para el NIR, utilizado en los observatorios de Mauna Kea (el sistema MKO-NIR). Los filtros de este sistema fueron diseñados de modo de minimizar la influencia de la absorción atmosférica en los mismos. El sistema de filtros MKO-NIR (que incluye las bandas $J, H, K_{s}, L^{\prime}$ y $M^{\prime}$ ) se muestra en detalle en la Figura 1.5 en línea continua gruesa, en la figura también se han graficado, en línea de puntos, el conjunto de filtros utilizado por Johnson en el estudio Johnson (1965) y las ventanas de transmisión atmosférica. La imagen fue tomada de Tokunaga \& Vacca (2007).

Una discusión detallada sobre los distintos sistemas fotométricos en el rango del NIR se puede encontrar en los trabajos de Tokunaga \& Vacca (2007) y Bessell (2005), Stephens \& Leggett (2004) y Tokunaga (2000) entre otros.

\subsection{Formación de estrellas de gran masa}

Cuando se habla de estrellas masivas (o, indistintamente, 'estrellas de gran masa') se está haciendo referencia a objetos estelares con masa inicial $M_{0} \gtrsim 8 M_{\odot}$. En la Tabla 1.2 se listan, como referencia, los rangos de masa, luminosidad y tipos espectrales abarcados por los conjuntos de estrellas a las que comúnmente se las denomina como 'estrellas de baja masa', 'estrellas de masa intermedia' y 'estrellas de gran masa' (y las subdivisiones dentro de este último grupo). Dicha Tabla es una adaptación de la Tabla 2 de Zinnecker \& Yorke (2007), completada con datos extraídos de Binney \& Merrifield (1998).

Las estrellas masivas son objetos cuya formación es poco frecuente en comparación con las estrellas de menor masa. Si se considera la Función Inicial de Masas $\left(\right.$ IMF $\left.^{9}\right)$ de Salpeter ${ }^{10}$ (Salpeter, 1955) el número de estrellas que se forman con masas $\mathrm{M}>8 \mathrm{M}_{\odot}$ constituye solo el $10 \%$ del número total de estrellas formadas con masas entre $1-2 \mathrm{M}_{\odot}$.

\footnotetext{
${ }^{9}$ IMF: del acrónimo en inglés de 'Initial Mass Function' (función inicial de masa).

${ }^{10} \mathrm{La}$ IMF representa numéricamente la distribución inicial de masas en el momento de la formación estelar, la IMF inicialmente propuesta por Salpeter tiene la forma de una ley de potencias: $\xi(\mathrm{M}) \propto \mathrm{M}^{\gamma}$ con $\gamma=-2.35$. Posteriormente, la IMF se ha subdivido en intervalos que abarcan distintos rangos de masas y el valor que toma el índice varía de acuerdo al intervalo considerado y a los autores. Las cuestiones vinculadas a la IMF constituyen uno de los temas más discutidos de la astrofísica de las últimas décadas (ver Bastian et al. (2010), Clarke (2009), Chabrier (2003), Kroupa (2002), Elmegreen (2001) y las referencias citadas en estos artículos).
} 


\begin{tabular}{cccc}
\hline Designación & Masa $\left(\mathrm{M} / \mathrm{M}_{\odot}\right)$ & Tipo Espectral & Luminosidad $\left(\log \left(\mathrm{L} / \mathrm{L}_{\odot}\right)\right)$ \\
\hline Estrellas de baja masa & $<2$ & $\mathrm{M}-\mathrm{G}$ & $<0.18$ \\
\hline Estrellas de masa intermedia & $2-6$ & $\mathrm{~F}-\mathrm{B} 5$ & $0.51-2.92$ \\
\hline Estrellas de alta masa & & & \\
\hline Estrellas B tempranas & $8-16$ & $\mathrm{BO}-\mathrm{B} 3$ & $3.28-4.72$ \\
Estrellas O tardías & $16-32$ & $\mathrm{O} 9-\mathrm{O} 6$ & $4.72-5.9$ \\
Estrellas O tempranas & $32-64$ & $\mathrm{O} 5-\mathrm{O} 2$ & $5.9-7.0$ \\
estrellas O/WR & $>64$ & O/WR & $>7$ \\
\hline
\end{tabular}

Tabla 1.2: Descripción de los rangos de masa, luminosidad y tipos espectrales abarcados por los conjuntos de estrellas a las que comúnmente se las denomina como 'estrellas de baja masa', 'estrellas de masa intermedia' y 'estrellas de gran masa' (y las subdivisiones dentro de este último grupo). Esta Tabla es una adaptación de la Tabla 2 de Zinnecker 85 Yorke (2007), completada con datos extraídos de Binney $\&$ Merrifield (1998).

La expresión 'procesos de formación estelar' comprende una secuencia de eventos que dan lugar a la formación estelar. Para estrellas de gran masa Bik et al. (2003), admitiendo la existencia de una nube molecular gigante, enumeran dicha secuencia del siguiente modo:

1. Fragmentación de la nube molecular gigante y formación de núcleos o filamentos moleculares densos (con densidad y temperatura características en el orden de $\mathrm{n} \sim 10^{5} \mathrm{~cm}^{-3}$ y $\mathrm{T} \sim 10-15 \mathrm{~K}$, respectivamente).

2. Colapso gravitacional de los núcleos en 'núcleos protoestelares'.

3. Acreción de material en los núcleos protoestelares.

4. Disipación de la nube originaria, debido a la acción combinada del viento estelar, radiación UV, eyecciones de materia en forma de 'outflows' y eventualmente eventos de supernovas de las estrellas masivas que evolucionan rápidamente.

Generalmente, el producto final de esta secuencia es una asociación o cúmulo de estrellas $\mathrm{OB}$, con una población asociada de estrellas de menor masa (según la IMF). Dado que la escala temporal en que se producen los procesos de formación estelar de estrellas de alta masa es extremadamente corta (del orden del millón de años), en dichas regiones suelen observarse varias generaciones de estrellas masivas.

Si bien se ha avanzado en el conocimiento relativo a la formación estelar de estrellas de gran masa, tanto desde el punto de vista observacional (con el advenimiento de la nueva generación de telescopios espaciales y terrestres, la tecnología en instrumental acompañada de nuevas técnicas observacionales, etc) como desde el punto de vista teórico (mayor capacidad computacional para calcular modelos cada vez más realistas que incluyen más elementos físicos), cada una de las etapas mencionadas lleva todavía asociada una enorme cantidad de cuestiones básicas no resueltas. 
El hecho de que la formación estelar se origine a partir de la fragmentación de nubes moleculares refuerza la idea, ampliamente aceptada, de que la formación estelar es un proceso grupal y no se produce aisladamente. En el transcurso de su evolución, mediante una variedad de efectos dinámicos (fuerzas de marea de la galaxia, segregación de masa, etc), los cúmulos pueden ir perdiendo sus miembros (hasta deshacerse completamente en los casos más extremos) y sus estrellas pasan a formar parte de la población de estrellas de campo de la galaxia.

Los procesos físicos que originan la fragmentación de las nubes moleculares gigantes y gobiernan la forma en que procede la fase de colapso gravitacional (incisos 1 y 2 de la secuencia mencionada) constituyen un punto de discusión importante en la astrofísica contemporánea. Una de las cuestiones fundamentales está vinculada a la relación existente entre la distribución de masas producida en la fragmentación de las nubes en núcleos densos y la masa final de las estrellas que allí se originan. Básicamente la discusión se centra en dos modelos diferentes. Por un lado, el modelo conocido como 'colapso monolítico' (McKee \& Tan, 2003), propone un proceso lento, en el cual los núcleos densos permanecen en un estado de cuasi-equilibrio entre la gravedad y la turbulencia interna. En este modelo los núcleos contienen desde su origen la masa suficiente para las estrellas que van a formar. Por el contrario, el modelo de 'acreción competitiva' (Bonnell et al., 1997, 2001) plantea un mecanismo que tiene lugar en escalas de tiempo más cortas. La idea propuesta en este modelo es que la distribución inicial de masas en los núcleos densos no guarda una relación directa con la masa final de la estrella a la que dará origen, debido a que el núcleo sigue acretando materia en función de su masa inicial, su ubicación dentro de la nube molecular y el gas disponible a su alrededor. El material acretado por el núcleo puede provenir de diferentes regiones de la nube original ya que es libre de moverse bajo los efectos gravitacionales de los núcleos. Este planteo implica que las estrellas formadas a partir de núcleos localizados en las regiones centrales de las nubes densas tienen mayor posibilidad de llegar a alcanzar masas finales más altas y, en cierto modo, justifica el efecto de segregación primordial de masas.

Tanto el modelo de 'colapso monolítico' como el de 'acreción competitiva' consideran la acreción de materia en el objeto protoestelar. Existe otra teoría, radicalmente diferente, que sostiene que las estrellas masivas podrían formarse a partir de la coalescencia de objetos estelares o protoestelares de menor masa (Bonnell et al., 1998). Este proceso tendría lugar en la formación de estrellas extremadamente masivas, en el centro de cúmulos altamente poblados y con un grado importante de segregación inicial de masas.

La discusión correspondiente al inciso 3 de la lista se centra en la forma en que se produce acreción de material en el objeto protoestelar. Los discos y eyecciones de materia son eventos asociados a la formación estelar de objetos de masa intermedia-baja, y su existencia ha sido confirmada por infinidad de observaciones (Noriega-Crespo et al., 2004; Jørgensen et al., 2009, e.g. ). La teoría estándar para la formación estelar, mediante la acreción de materia en la fase de pre-secuencia principal es aplicable a objetos de baja masa, con masas subsolares y solares (estrellas de tipo TTauri) y objetos de masa intermedia, entre 2-10 $\mathrm{M}_{\odot}$ (estrellas Herbig 
$\mathrm{Ae} / \mathrm{Be})$. Pero la formación de estrellas de gran masa no es necesariamente una versión en escalas mayores de la formación de objetos de menor masa. Para las estrellas de baja masa el proceso de acreción termina antes de que la estrella comience a fusionar $\mathrm{H}$ en el núcleo (antes de llegar a la ZAMS $^{11}$ ). Las estrellas de gran masa prácticamente se forman en la secuencia principal, comienzan a fusionar $\mathrm{H}$ en el núcleo muy rápidamente y no atraviesan una fase de pre-secuencia bien definida. El proceso de acreción continua aun después de haberse iniciado la fusión de $\mathrm{H}$ en el núcleo. La influencia de la radiación sobre el gas y el polvo en los alrededores de un objeto en formación comienza a ser un factor fundamental en estrellas de tipo espectral B tempranas. Algunos autores plantean que la forma más efectiva en las protoestrellas masivas para superar la presión de radiación y continuar con las últimas fases del proceso de acreción de materia es mediante discos de acreción. Las evidencias observacionales de la existencia de discos alrededor de estrellas de gran masa son cada vez más numerosas (ver por ejemplo lo estudios de Chini et al., 2004 y Beltrán et al., 2004), sin embargo en muchos casos suelen ser indirectas (e.g. a través de observaciones de eyecciones de materia). Se ha calculado que las escalas de tiempo de destrucción de los discos alrededor de estrellas masivas es muy corta, del orden de $\sim 10^{5}$ años, lo cual dificulta aun más su observación. Cesaroni et al. (2007) realizan una compilación de estudios muy completa y detallada que abarca distintos aspectos, tanto teóricos como observacionales, relativos a los discos de acreción alrededor de estrellas de gran masa.

\subsection{Formación estelar inducida}

Una vez producido el primer evento de formación estelar masiva (por ejemplo, mediante algún proceso dinámico que genere inestabilidad gravitacional en la nube molecular gigante), la formación estelar de objetos de alta masa es un proceso que se realimenta, siempre que haya suficiente material disponible para seguir formando estrellas.

Para inducir la formación estelar es necesaria una fuente de energía que pueda cambiar el estado de una nube molecular de 'estable' a 'inestable' y provocar el colapso gravitacional. El colapso gravitacional requiere en general, algún tipo de compresión, la masa comprimida debe exceder la masa de inestabilidad y la fuerza compresora debe durar un tiempo comparable al tiempo de colapso de la región comprimida. En las asociaciones OB, y otros complejos de estrellas masivas, las fuentes de energía capaces de inducir la formación estelar están provistas por la expansión de regiones HII, los vientos generados por las estrellas masivas y las explosiones múltiples de supernovas. A escalas galácticas la formación estelar masiva puede ser inducida por las ondas de densidad espirales o la perturbación de nubes moleculares producidas por ejemplo en encuentros entre galaxias.

Elmegreen (1998) distingue particularmente tres procesos dinámicos mediante los cuales

\footnotetext{
11ZAMS: del acrónimo en inglés de 'Zero Age Main Sequence' (secuencia principal de edad cero).
} 
la formación estelar masiva puede ser inducida. Estos procesos, en general, se corresponden con escenarios de formación estelar en tres escalas distintas, considerando los tamaños de las regiones en las que se induce la formación estelar y las regiones que la inducen:

- Compresión directa de nubes o glóbulos preexistentes por altas presiones ejercidas sobre toda la superficie de los mismos. Estos procesos corresponden a la escala más pequeña de formación estelar inducida y se producen en glóbulos de $\mathrm{HI}$ inmersos en regiones HII, glóbulos cometarios, etc. Este escenario, conocido como 'globule squeezing', puede observarse, en las regiones galácticas de M 16, M 8 y Orión, entre otras.

- Compresión de una nube de gas molecular de un solo lado. En el frente comprimido de la nube se produce una acumulación de material denso en capas o núcleos que eventualmente colapsan. Este mecanismo se corresponde con eventos de formación estelar en escala intermedia, como los observados en M 17 y NGC 346 (en SMC ${ }^{12}$ ).

- Acumulación de gas en anillos o cáscaras en expansión que parcialmente rodean la fuente que genera la presión; dicho material eventualmente puede colapsar generando estrellas en la periferia de la burbuja. El tamaño de la burbuja generada depende de la relación entre las presiones interna y externa a la misma (pudiendo alcanzar radios de cientos de parsecs). Estos eventos se observan en regiones Hil gigantes, en N 11 (en $\mathrm{LMC}^{13}$ ), y en regiones como el anillo de Lindblad en la Vía Láctea.

A los últimos dos procesos mencionados de formación inducida se los denomina en forma genérica como 'collect and collapse'.

Debido a que las estrellas se forman en el interior de los núcleos densos, fuera de la influencia directa de las fuentes de presión que puedan estar actuando en la superficie del material comprimido, el proceso final de la formación estelar 'individual' (el colapso protoestelar, la formación de discos de acreción, etc) no es fuertemente dependiente del mecanismo por el cual fue inducida la formación estelar. La IMF sólo podría verse afectada en el caso en que la fuente de compresión también caliente significativamente el gas (Elmegreen, 2011).

La evidencia de formación estelar inducida involucra condiciones de causalidad entre las escalas espaciales de las regiones y la diferencia de edades y velocidades de las estrellas cuya formación fue inducida respecto de las estrellas que indujeron la formación. Si no se puede establecer una diferencia de edad inequívoca, las estrellas podrían ser producto del proceso general inicial de formación estelar.

\subsection{Objetos con exceso IR en regiones de formación estelar}

En esta Sección se presentan brevemente los objetos que pueden exhibir exceso IR en una región de formación estelar masiva.

\footnotetext{
${ }^{12}$ SMC: del acrónimo en inglés de 'Small Magellanic Cloud' (Nube Menor de Magallanes).

${ }^{13}$ LMC: del acrónimo en inglés de 'Large Magellanic Cloud' (Nube Mayor de Magallanes).
} 
La Figura 1.7 muestra un diagrama color-magnitud (CM), tomado de la publicación de Bik et al. (2006), en el cual se han graficado MYSOs observados en M 17 y W31. La figura también muestra la ubicación de la ZAMS como referencia y, en forma esquemática, las áreas ocupadas por las estrellas Be, las Herbig Ae/Be y las supergigantes B[e]. En el Capítulo 3 de la presente Tesis se estudiará el diagrama color-magnitud obtenido para los objetos de NGC 604; en comparación con el diagrama CM de la Figura 1.7, el diagrama de NGC 604 comienza en $K s=-3.5$, por lo tanto incluye sólo a los objetos más luminosos de la región en $K s$ y es poco probable que se observen objetos de masa intermedia-baja como estrellas Be y Herbig $\mathrm{Ae} / \mathrm{Be}$.

\section{Objetos masivos jóvenes}

Para comenzar con la descripción de la emisión de los MYSOs observada en el NIR, se ha incluido la Figura 1.8, la cual muestra una secuencia de espectros en la banda $K$ de distintos objetos observados por Bik et al. (2005a). Los autores realizaron un estudio espectroscópico (en la banda $K$, con observaciones de VLT) de estrellas masivas inmersas en fuentes IRAS con colores de regiones HII ultracompactas $\left(\mathrm{UCHIIs}^{14}\right.$ ). Esta figura permite distinguir claramente las diferencias entre los espectros de los distintos tipos de objetos. Los paneles (a) y (b) muestran emisión fotosférica típica de estrellas de tipo espectral O y B respectivamente. El panel (c) corresponde a un espectro que se encuentra dominado por la emisión nebular de una UCHII, notar que el flujo de este espectro fue graficado en escala logarítmica. El panel (d) muestra la emisión proveniente de un objeto que presenta características de MYSO. Finalmente, el panel (e), corresponde al espectro de una estrella tardía de campo. Es interesante observar que el espectro del panel (c) exhibe líneas de emisión muy angostas e intensas en comparación con las del espectro mostrado en (d).

Los objetos masivos jóvenes se encuentran rodeados de material circumestelar y presentan exceso de emisión en el IR. En general, suelen ser los objetos más rojos de los cúmulos a los que pertenecen. En el espectro de la banda $K$ presentan líneas de emisión anchas, cuyos anchos típicos están comprendidos en el rango entre $\sim 100-250 \mathrm{~km} \mathrm{seg}^{-1}$. Entre las líneas de emisión más características se encuentran las cabezas de banda de $\mathrm{CO}$, las líneas de $\mathrm{H}$ (a veces con perfiles de doble pico y asimétricos) y líneas de FeII $(2.089 \mu \mathrm{m})$ y MgII $(2.138$ y $2.144 \mu \mathrm{m})$. En muchos objetos se observa la serie del $\mathrm{H}$ de Pfund, el gas ionizado en donde se generan las líneas de esta serie tiene una densidad electrónica del orden de $\mathrm{n}_{e} \sim 10^{8} \mathrm{~cm}^{-3}$, mientras que la emisión de $\mathrm{CO}$ proviene de una zona más densa $\left(\mathrm{n}_{e} \sim 10^{10} \mathrm{~cm}^{-3}\right)$ y de altas temperaturas (T 2000-5000 K), la cual debe estar suficientemente protegida de la radiación UV de las estrellas masivas que desintegra la molécula de CO. Para ilustrar lo descripto, en la Figura 1.9, se muestra un espectro típico en la banda $\mathrm{K}$ de un MYSO conocido como IRS 2E, perteneciente a la región HII compacta galáctica W51 IRS2. Dicho objeto fue observado por Barbosa et al. (2008) con Gemini-NIFS. El flujo en la imagen se ha graficado en unidades arbitrarias.

\footnotetext{
${ }^{14}$ UCHıI: del acrónimo en inglés de 'Ultra Compact Hiı Region’ (región Hit ultracompacta).
} 


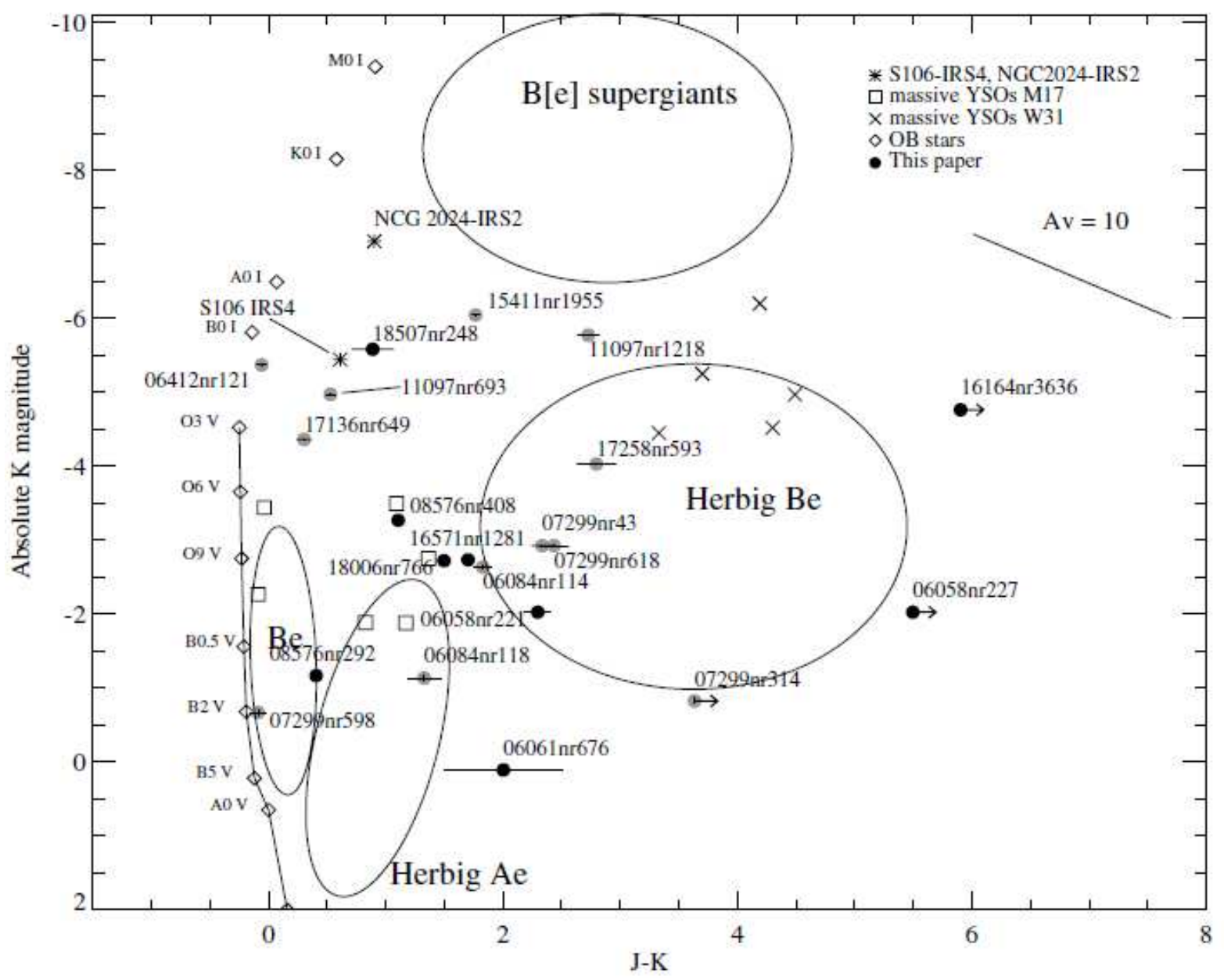

Figura 1.7: Diagrama color-magnitud, tomado de la publicación de Bik et al. (2006), en el cual se han graficado MYSOs observados en M17 y W31. La figura también muestra la ubicación de la ZAMS como referencia y, en forma esquemática, las áreas ocupadas por las estrellas Be, las Herbig Ae/Be y las supergigantes B[e]. 


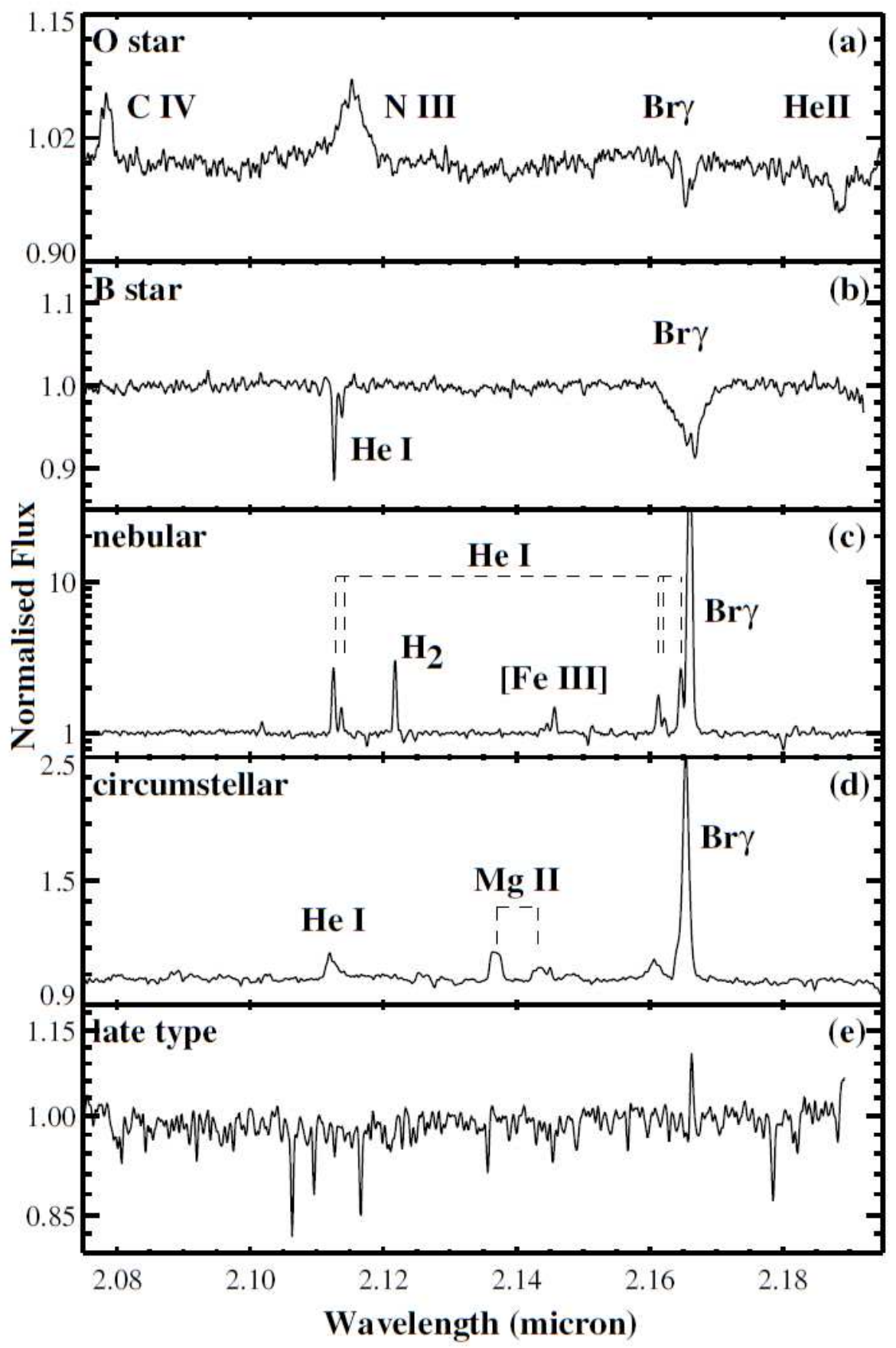

Figura 1.8: Secuencia de espectros en la banda $K$ corresponden a distintos objetos observados por Bik et al. (2005a). Los paneles (a) y (b) muestran emisión fotosférica típica de estrellas de tipo espectral $O$ y $B$ respectivamente. El panel (c) es un espectro que se encuentra dominado por la emisión nebular de una UCHII, notar que el flujo de este espectro fue graficado en escala logarítmica. El panel (d) muestra emisión proveniente de un objeto que presenta características de MYSO. Finalmente, el panel (e), corresponde al espectro de una estrella tardía de campo. 


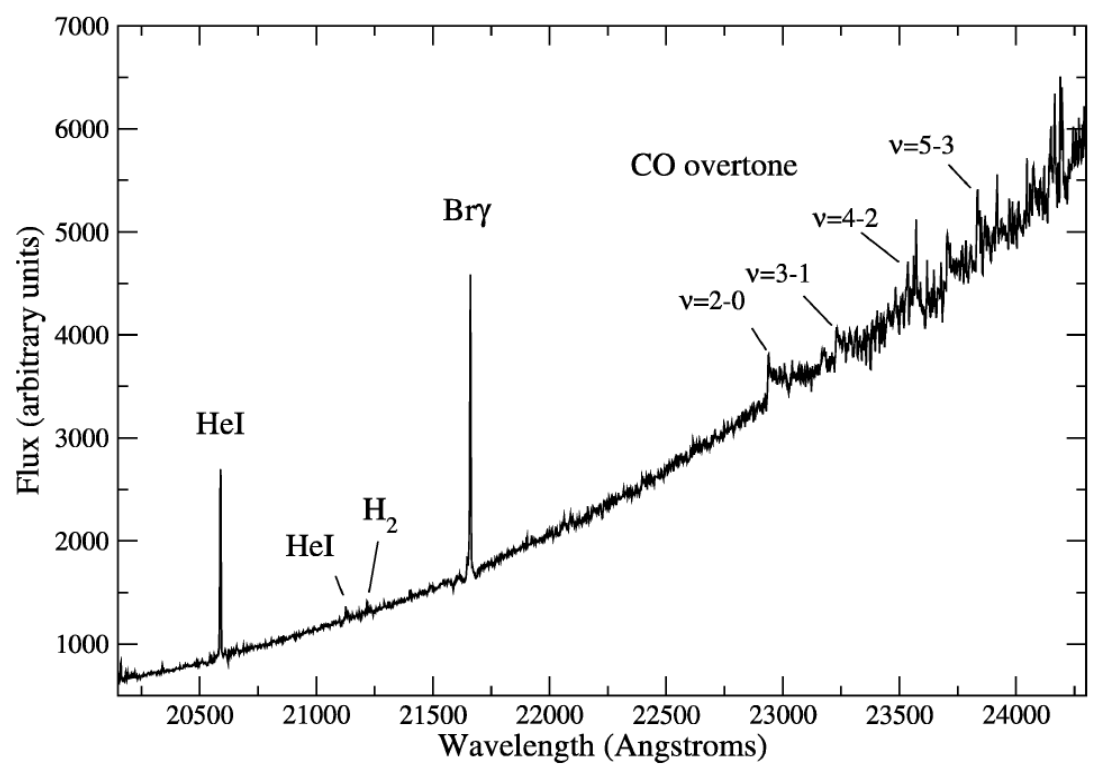

Figura 1.9: Espectro en la banda $K$ del MYSO IRS 2E, perteneciente a la región HII compacta galáctica W51 IRS2. Este objeto fue observado por Barbosa et al. (2008) con Gemini-NIFS. El flujo tiene unidades arbitrarias.

Las líneas de emisión observadas en los espectros de los MYSOs requieren diferentes condiciones físicas para ser generadas, de modo que deben producirse en diferentes regiones del medio circumestelar que rodea al objeto. Este hecho presenta ciertos argumentos en favor de la existencia de discos de acreción alrededor de objetos masivos en formación. La Figura 1.10 muestra esquemáticamente un modelo de disco propuesto por Bik et al. (2005b) y las diferentes regiones de formación de las líneas de emisión observadas en los espectros de los MYSOa. EI $\mathrm{CO}$ se encuentra en el plano medio del disco, que es una región relativamente densa, mientras que las líneas de $\mathrm{H}$ son emitidas por el gas ionizado en la superficie o en el viento del propio disco.

\section{Estrellas masivas evolucionadas}

Otros objetos que pueden observarse con exceso IR son ciertos tipos de estrellas ya evolucionadas de la secuencia principal, como estrellas Wolf-Rayet (WR) y la supergigantes Of y $\mathrm{B}[\mathrm{e}]$. La Figura 1.11 corresponde al espectro en la banda $K$ de cuatro objetos de post secuencia principal. En esta figura se puede observar la presencia de las líneas anchas de emisión que contribuyen al exceso IR observado en dichas estrellas. La imagen fue tomada del trabajo de Martins et al. (2007). 


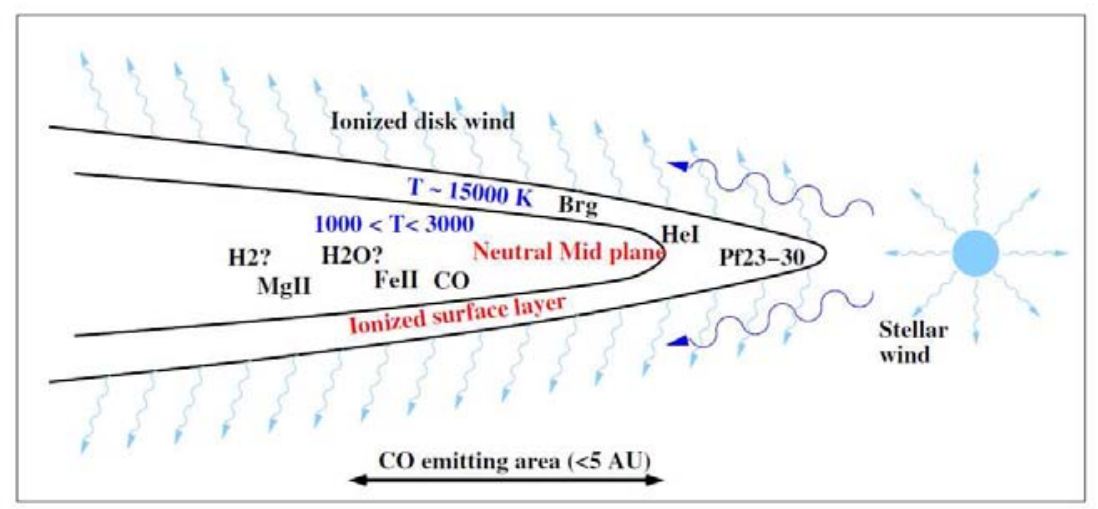

Figura 1.10: Esquema de un modelo de disco acreción propuesto por Bik et al. (2005b) y las diferentes regiones de formación de las líneas de emisión. El CO se encuentra en el plano medio del disco, que es una región relativamente densa, mientras que las líneas de $H$ son emitidas por el gas ionizado en la superficie del disco o en el viento del disco.

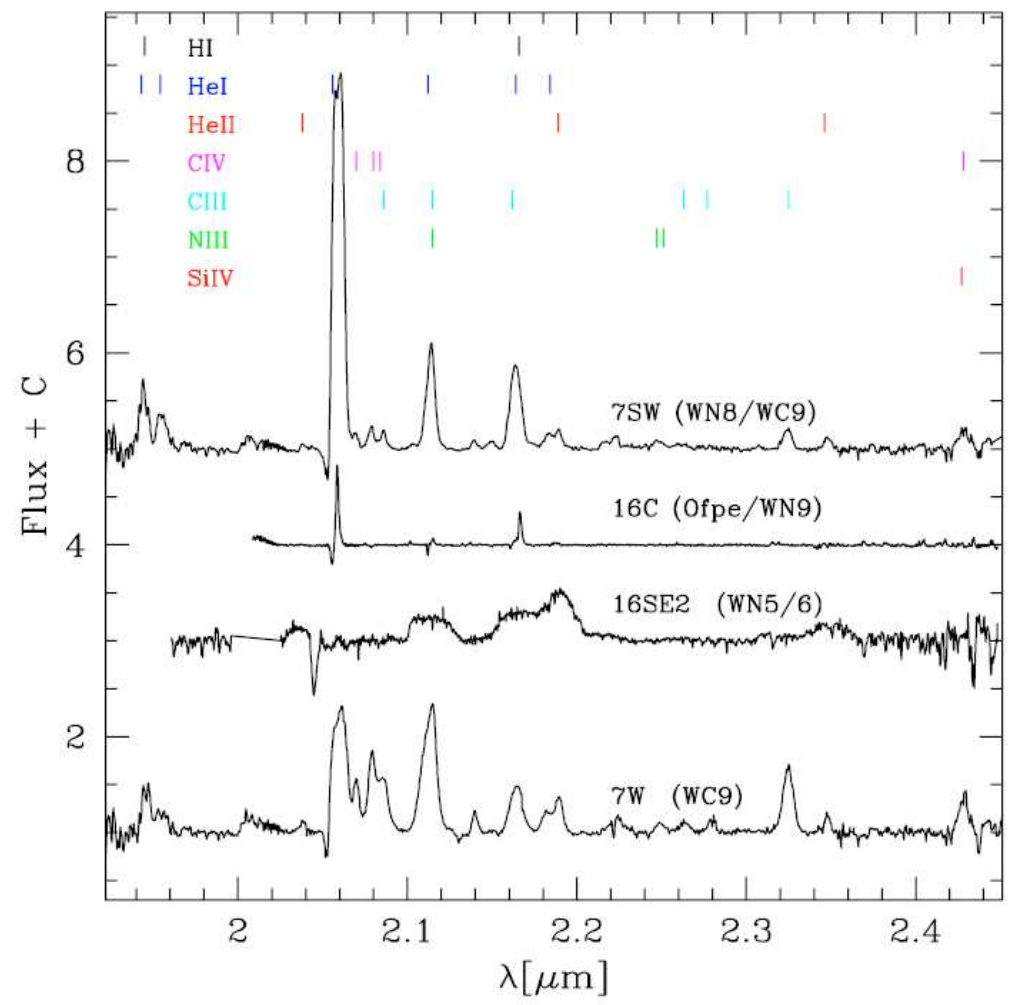

Figura 1.11: Espectro en la banda K, de cuatro objetos de post secuencia principal. La imagen fue tomada del trabajo de Martins et al. (2007). 


\begin{tabular}{|c|c|c|c|c|c|c|}
\hline Región HiI & $\begin{array}{l}\text { Diámetro } \\
(\mathrm{pc})\end{array}$ & $\begin{array}{c}\mathrm{L}\left(\mathrm{H}_{\alpha}\right) \\
\left(\text { ergs s}^{-1}\right)\end{array}$ & $\begin{array}{c}\mathrm{M}\left(\mathrm{H}^{+}\right) \\
\left(\mathrm{M}_{\odot}\right)\end{array}$ & $\begin{array}{c}\mathrm{M} \star(\mathrm{OB}) \\
\left(\mathrm{M}_{\odot}\right)\end{array}$ & $\begin{array}{c}\text { Equiv. } \\
\text { N(O5 V) }\end{array}$ & $\begin{array}{c}\text { Galaxia - } \\
\text { Distancia (kpc) }\end{array}$ \\
\hline Orion & 5 & $1 \times 10^{37}$ & 50 & 35 & $0.2^{\natural}$ & $\mathrm{MW}^{\dagger}-0.5$ \\
\hline M 8 & 25 & $3 \times 10^{37}$ & 900 & 100 & 0.5 & MW - 1.4 \\
\hline Carinae & 200: & $6 \times 10^{38}$ & 44000 & 2000 & 9 & MW - 1.4 \\
\hline NGC 3603 & 100: & $1.5 \times 10^{39}$ & 39000 & 5000 & 20 & MW - 8.5 \\
\hline W 49 & 150: & $2 \times 10^{39}$ & 45000 & 7000 & 27 & MW -14.1 \\
\hline N 70 & 110 & $5 \times 10^{37}$ & 7000 & 180 & 1 & LMC - 50 \\
\hline N 19 & 220 & $2.2 \times 10^{38}$ & 55000 & 700 & 3 & $\mathrm{SMC}-70$ \\
\hline NGC 592 & 360 & $3 \times 10^{38}$ & $\ldots$ & 1000 & 5 & M $33-840$ \\
\hline NGC 595 & 400 & $2.3 \times 10^{39}$ & $\ldots$ & 7000 & 30 & M $33-840$ \\
\hline NGC 604 & 400 & $4.5 \times 10^{39}$ & $7 \times 10^{5}$ & 15000 & 65 & M $33-840$ \\
\hline 30 Dor & 370 & $1.5 \times 10^{40}$ & $6 \times 10^{5}$ & 50000 & 230 & LMC -50 \\
\hline NGC 5471 & 800 & $5 \times 10^{40}$ & $9 \times 10^{6}$ & $1.0 \times 10^{5}$ & 450 & M $101-6000$ \\
\hline NGC 5461 & 1000: & $7 \times 10^{40}$ & $6 \times 10^{6}$ & $1.7 \times 10^{5}$ & 750 & M $101-6000$ \\
\hline
\end{tabular}

Ł El cúmulo del Trapecio, en la nebulosa de Orión, contiene sólo una estrella O6, el resto son estrellas de tipo espectral B.

† MW: del acrónimo en inglés de 'Milky Way' (Vía Láctea).

Tabla 1.3: Parámetros de regiones HII galácticas y GHRs. En las Columnas 2 y 3 se listan el diámetro visual (derivado de la emisión de $H \alpha$ ) y la luminosidad en $H \alpha$, respectivamente. Las Columnas 4, 5 y 6 contienen la masa de gas ionizado, la masa de estrellas y el número equivalente de estrellas $05 \mathrm{~V}$ necesarias para alcanzar la luminosidad de ionización. La Columna 7 indica la galaxia a la que pertenecen las regiones y su correspondiente distancia. Las regiones HII, GHR extragalácticas y los valores de los parámetros físicos listados fueron seleccionados del estudio de Kennicutt (1984).

\subsection{Regiones HII gigantes}

Las regiones $\mathrm{H}$ II son básicamente regiones de $\mathrm{H}$ ionizado por la radiación en el continuo de Lyman emitida por estrellas masivas de tipos espectrales $\mathrm{O}$ y $\mathrm{B}$ tempranas. Los iones más abundantes en estas regiones incluyen $\mathrm{H}^{+}, \mathrm{He}^{+}, \mathrm{O}^{+}$y $\mathrm{O}^{++}$. Las transiciones (desexcitaciones) entre niveles ligados de los iones generan el espectro de líneas de emisión característico de estas regiones. Las transiciones ligado-libre y libre-libre generan el continuo.

Las regiones HiI abarcan un rango de escalas espaciales que va desde unos pocos parsecs hasta miles de parsecs, en el caso de las regiones GHRs. Sus luminosidades, masas, densidades y otras características físicas también varían de una región Hil a otra. En la Tabla 1.3 se han seleccionado, sólo como referencia, algunas regiones HII galácticas y GHRs extragalácticas, la tabla lista los valores del diámetro visual (derivado a partir de la emisión de $H \alpha$, como indicador del tamaño), la luminosidad en $H \alpha$, la masa de gas ionizado, la masa de estrellas, el número 
equivalente de estrellas $05 \mathrm{~V}$ necesarias para alcanzar la luminosidad de ionización de la región y la galaxia a la que pertenecen junto con la distancia a la que se encuentran. Las regiones HII, GHRs y los valores de los parámetros físicos listados fueron seleccionados del estudio realizado por Kennicutt, 1984 (cabe aclarar que muchos de los valores de los parámetros listados han sido medidos y/o recalculados nuevamente en estudios más recientes).

Las GHRs son objetos extremadamente luminosos que pueden ser observados a grandes distancias; de hecho, se las utiliza como indicadores de distancias y trazadores de composición química, estructura espiral y tasa de formación estelar (de estrellas de gran masa) de galaxias distantes. A grandes distancias las GHRs pueden distinguirse de las aglomeraciones de regiones HiI por el hecho de que los anchos observados en sus perfiles de emisión corresponden a velocidades supersónicas del gas. Como se observa en la Tabla 1.3, las GHRs albergan una enorme cantidad de estrellas de gran masa y, en consecuencia, al igual que las regiones HII, están necesariamente ligadas a procesos de formación estelar masiva ${ }^{15}$ y constituyen excelentes lugares donde buscar, observar y estudiar cómo proceden los distintos modos de formación estelar a escala global (por ejemplo, los escenarios de formación estelar inducida mencionados anteriormente) y, donde sea posible, los procesos de formación de las estrellas de gran masa individualmente. Sin embargo, dado que la mayoría de las GHRs se encuentran ubicadas a grandes distancias, su estudio debe restringirse a las características globales observables. De modo que el estudio detallado de las GHRs más cercanas, cuyos objetos individuales y estructuras a pequeña escala pueden resolverse, resulta de fundamental importancia, ya que permite identificar las causas físicas que originan las características de la emisión global observada para GHRs más distantes.

Las dos GHRs más importantes del Grupo Local de galaxias son 30 Doradus (30 Dor) en LMC (a $50 \mathrm{kpc}, 1^{\prime \prime}$ equivale a 0.25 pc) y NGC 604 en M 33 (a $840 \mathrm{kpc}, 1^{\prime \prime}$ equivale a 4.1 pc). Si bien la distancia a NGC 604 es aproximadamente 17 veces mayor que la distancia a 30 Dor, afortunadamente ambas regiones se encuentran lo suficientemente cerca como para poder estudiar su estructura nebular en detalle y sus objetos individualmente y, a la vez, lo suficientemente lejos como para observar las estructuras y emisión a gran escala. Esta condición permite realizar estudios en los cuales es posible comprobar si las caracterícas físicas derivadas a partir de la emisión integrada de las GHRs, se corresponden con lo que se observa al resolverlas en sus objetos individuales. De este modo, se pone a prueba la aplicabilidad de métodos y criterios aplicados a la emisión integrada de otras GHRs que no pueden resolverse. Más aun, ambas regiones están en una dirección fuera del plano galáctico lo cual facilita enormemente los estudios observacionales, ya que no se ven tan afectadas por la contaminación de objetos de campo y la alta extinción producida por el polvo presente en la región del disco galáctico. Por

\footnotetext{
${ }^{15}$ Las estrellas de gran masa son objetos intrínsecamente jóvenes debido a que sus tiempos evolutivos son extremadamente cortos (del orden de unos pocos millones de años para las estrellas de tipo espectral $\mathrm{O})$.
} 
estas razones, entre otras, ambas regiones fueron, son y serán el objeto central de infinidad de estudios observacionales, fuente de nuevos descubrimientos, motivadoras de teorías y campos donde poner a prueba los resultados de los modelos, especialmente en temas vinculados a la formación de estrellas de gran masa.

NGC 604 y 30 Dor presentan algunas características físicas similares, sin embargo también exhiben diferencias importantes en cuanto a su estructura y a la historia de formación estelar, lo que hace aún más enriquecedor su estudio y la comparación entre las propiedades de ambas GHRs.

De acuerdo a la clasificación definida en el estudio de Maíz-Apellániz (2001), los cúmulos centrales de estrellas masivas de las GHRs pueden dividirse en dos categorías, básicamente en función de su distribución estelar espacial y su estructura: 'supercúmulos estelares' $\left(\mathrm{SSCs}^{16}\right)$ y 'asociaciones OB escaladas' (SOBAs ${ }^{17}$ ). Los SSCs están organizados alrededor de un núcleo compacto (1-3 pc) y suelen presentar un halo de estrellas más extendido. Las SOBAs, en cambio, exhiben una estructura menos organizada y más extendida y no se observa en ellas un núcleo central de estrellas masivas. El autor propone que el origen de dicha distinción en la estructura de los cúmulos está ligado a la distribución original de masa en la nube molecular gigante de la cual se formaron. Considerando la evidencia observacional de que los SSCs se encuentran más frecuentemente en galaxias interactuantes, galaxias irregulares y galaxias enanas pero son relativamente escasos en galaxias espirales, Weidner et al. (2010) proponen como posible explicación a la diferencia estructural entre los SSCs y las SOBAs la presencia de fuerzas de 'cizalla' en las galaxias de disco (debido a que estas son sistemas rotantes). Dichas fuerzas tienen un efecto importante en la fragmentación de las nubes moleculares gigantes que actúa inhibiendo la formación de SSCs y favoreciendo la de cúmulos tipo SOBAs. La estructura y ubicación de los cúmulos estelares tienen consecuencias en su evolución dinámica a gran escala: las SOBAs serán más afectadas por las fuerzas de marea de la galaxia y son proclives de la desintegración en escalas de tiempo más cortas que la edad del universo, mientras que los SSCs podrían llegar a ser los cúmulos globulares del futuro. En el contexto de esta clasificación, el cúmulo de 30 Dor pertenece al grupo de los SSCs, mientras que el de NGC 604 constituye el prototipo de la estructura de las SOBAs.

El núcleo central de estrellas masivas de 30 Dor, el SSC R136, mide aproximadamente 2.5 pc y contiene la mayor concentración conocida de estrellas O3 (39 estrellas O3 según el estudio de Massey \& Hunter, 1998). NGC 2070, el cúmulo ubicado alrededor de R136, tiene un diámetro de $\sim 40$ pc y la nebulosa de la Tarántula de $\sim 200$ pc (Walborn, 1991). De acuerdo al estudio sobre la población estelar de NGC 604 realizado por Hunter et al. (1996), la densidad de estrellas masivas en R136 es aproximadamente 100 veces más alta que en las partes más densamente pobladas de NGC 604 y la región de 30 Dor contiene varias veces el número de

\footnotetext{
${ }^{16}$ SSC: del acrónimo en inglés de 'Super Star Cluster' (supercúmulos estelares).

${ }^{17}$ SOBA: del acrónimo en inglés de 'Scaled OB Association' (asociación OB escalada).
} 
estrellas luminosas del 'Cúmulo A' de NGC 604 (el 'Cúmulo A' incluye los objetos de las SOBA I y II de la Figura 1.14). La Figura 1.12 se ha incluido con el fin ilustrar las dimensiones y proporciones involucradas en el presente estudio. En dicha figura se han puesto en escala, considerando su extensión angular a la distancia de NGC 604, una imagen de NGC 2070 y la nebulosa de la Tarántula y una de R136. La imagen de NGC 2070, tomada del archivo del Australian Astronomical Observatory, abarca un área de $\sim 150 \times 150 \mathrm{pc}^{2}$ (equivalente a $\sim 37^{\prime \prime} \times 37^{\prime \prime}$ a la distancia de NGC 604). La imagen de R136, perteneciente a Andersen et al. (2009), abarca un área de $14 \times 14 \mathrm{pc}^{2}$ (equivalente a $\sim 3.5^{\prime \prime} \times 3.5^{\prime \prime}$ a la distancia de NGC 604). La imagen de fondo es una imagen del campo de NGC 604 de Gemini-NIRI (banda Br $\gamma$ ), que abarca un área de $420 \times 420 \mathrm{pc}^{2} \sim 100^{\prime \prime} \times 100^{\prime \prime}$.

Con respecto a la formación estelar en 30 Dor, es interesante recordar brevemente que, Walborn \& Blades (1997), mediante la clasificación espectral de 106 estrellas pertenecientes a 30 Dor, distinguieron 5 grupos estelares de acuerdo a su estado evolutivo. En dicho estudio los autores concluyeron que la formación estelar en 30 Dor no fue un proceso instantáneo ni tampoco continuo, sino que las estrellas se han ido formando en eventos discretos producidos en distintas épocas. En un trabajo posterior, Selman et al. (1999) confirman que la historia de formación estelar de 30 Dor está dominada por al menos tres eventos de formación estelar, producidos hace 5, 2.5 y 1.5 millones de años. Numerosos estudios presentan evidencias de que el proceso de formación estelar en 30 Dor continúa actualmente.

\subsection{NGC 604}

En la literatura puede encontrarse una gran cantidad y variedad de publicaciones con resultados de investigaciones dedicadas al estudio de distintos aspectos de la región NGC 604. En esta Sección se realiza un compendio de los principales resultados y datos publicados con el propósito de plantear el contexto en el cual se enmarca estudio realizado en esta Tesis.

Como se mencionó previamente, NGC 604 se encuentra ubicada en M33, la tercer galaxia más importante del Grupo Local, clasificada como SA(s)cd ${ }^{18}$ (de Vaucouleurs et al., 1991), a una distancia de $840 \mathrm{kpc}$ (Freedman et al., 2001) para la cual 1" equivale a 4.1 pc. Desde el punto de vista observacional la ubicación de NGC 604 es ventajosa: se encuentra localizada en las afueras de un brazo espiral de $\mathrm{M} 33$, a $2.5 \mathrm{kpc}$ al noreste del centro de la galaxia, en una dirección de observación fuera del plano de la Vía Láctea (coordenadas galácticas: $\left.\mathrm{I}=133^{\circ} .755896, \mathrm{~b}=-31^{\circ} .179006\right)$. Además, M 33 es una galaxia que se orienta prácticamente de frente, con un águlo de inclinación $\mathrm{i}=57^{\circ}$ (Ivanov \& Kunchev, 1985), de modo que se espera que en las imágenes de NGC 604 la contaminación de objetos de campo, tanto por objetos de la Via Láctea como por objetos propios de M33, sea mínima, al igual que la extinción. El valor de

\footnotetext{
${ }^{18} \mathrm{SA}(\mathrm{s}) \mathrm{cd}$ : galaxia espiral, no barrada.
} 


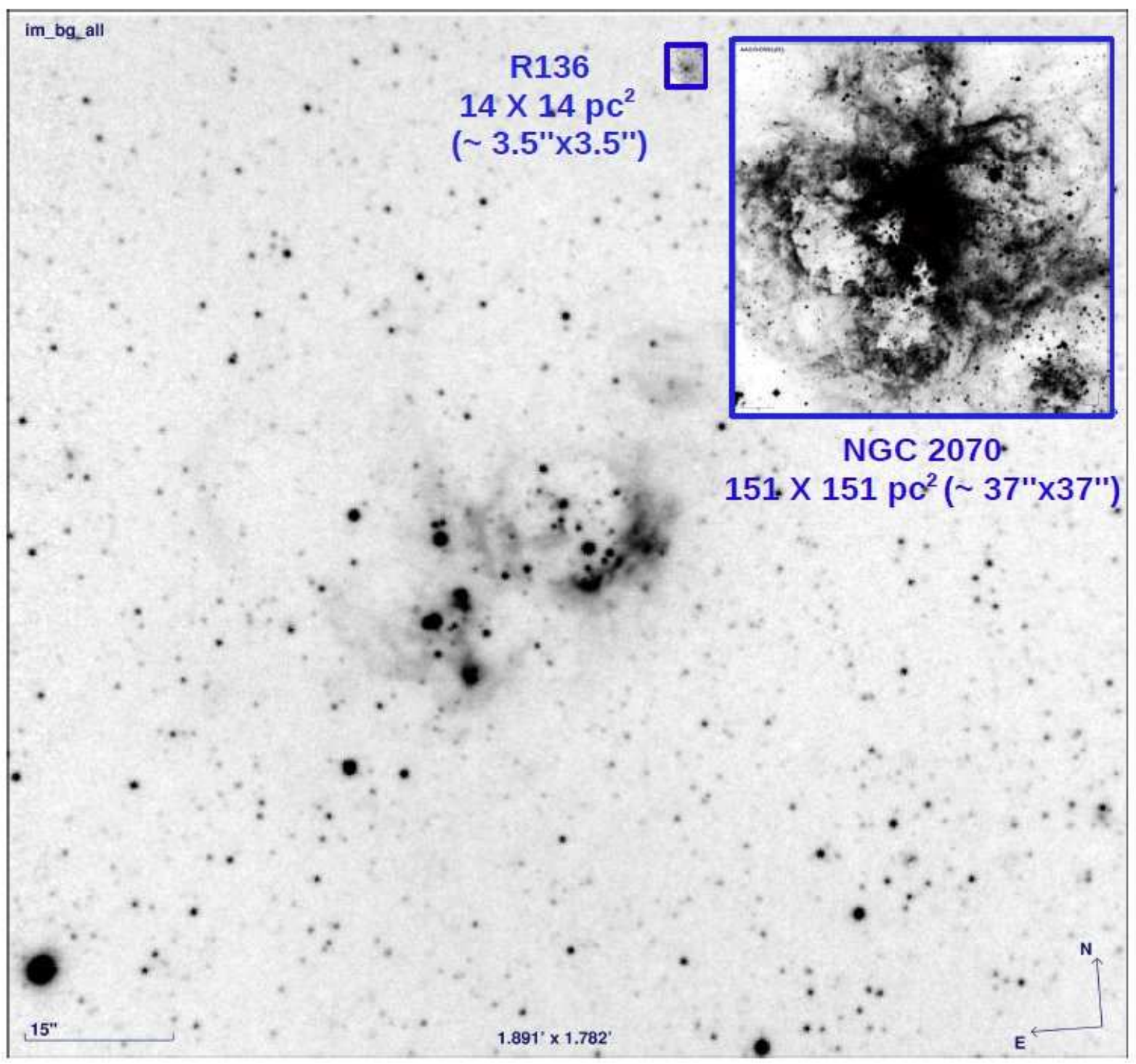

Figura 1.12: Imagen de NGC2070 y la nebulosa de la Tarántula tomada del archivo del Australian Astronomical Observatory. Dicha imagen abarca un área de $\sim 150 \times 150 p^{2}$ (equivalente $a \sim 3^{r \prime} \times 3^{\text {rl }}$ a la distancia de NGC604). A su izquierda se incluyó una imagen de R136 que abarca un área de $14 \times 14 p c^{2}$ (equivalente a $\sim 3.5^{\prime \prime} \times 3.5^{\prime \prime}$ a la distancia de NGC 604). La imagen de R136 pertenece a Andersen et al. (2009). La imagen de fondo es una imagen del campo de NGC 604 de Gemini-NIRI (banda Bry), que abarca un área de $420 \times 420 p c^{2} \sim 100^{\prime \prime} \times 100^{\prime \prime}$. 


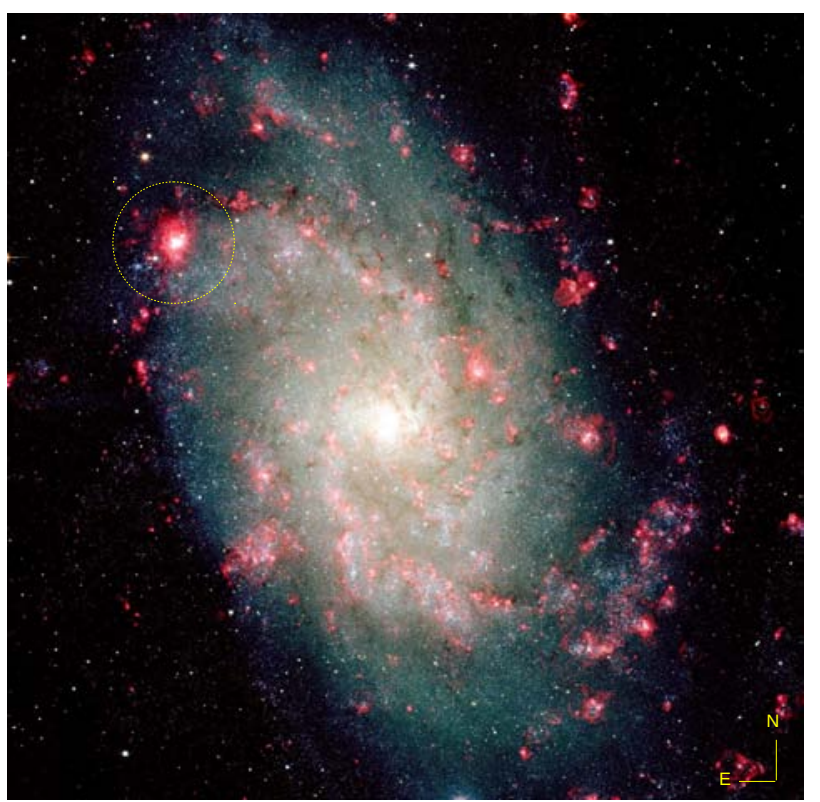

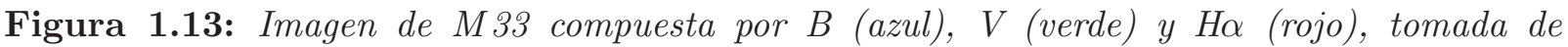
'A Survey of the Resolved Stellar Content of Nearby Galaxies Currently Forming Stars' en http://www.lowell.edu/users/massey/lgsurvey.html. El círculo amarillo al noreste de la imagen señala la posición de NGC604. En la imagen resulta evidente que NGC604 es el objeto más prominente en Ha de toda la galaxia.

la extinción galáctica en la dirección de NGC 604 calculado por NED ${ }^{19}$ es de $A_{V}=0.15$ mag con $\mathrm{E}_{(B-V)}=0.046$ mag. En la Figura 1.13 se muestra la ubicación de NGC 604 en M 33, marcada

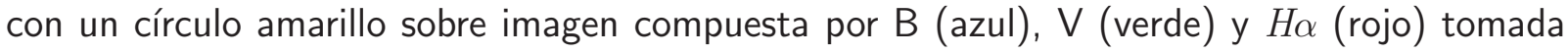
de 'A Survey of the Resolved Stellar Content of Nearby Galaxies Currently Forming Stars' ${ }^{20}$. En la imagen resulta evidente que NGC 604 es el objeto más prominente en $H \alpha$ de toda la galaxia, siendo su luminosidad en $H \alpha, \mathrm{L}(H \alpha)=2.6 \times 10^{39} \mathrm{erg} \mathrm{s}^{-1}$ (Bosch et al., 2002).

La Figura 1.14 muestra una imagen del campo de NGC 604 compuesta con las bandas $J$ (azul), $H$ (verde) y $K s$ (rojo) de las imágenes de Gemini-NIRI utilizadas en esta Tesis. El campo es de $\sim 120^{\prime \prime} \times 120^{\prime \prime}\left(\sim 490 \times 490 \mathrm{pc}^{2}\right)$. La imagen está orientada con el norte hacia arriba y el este hacia la izquierda. En dicha figura se han señalado regiones y fuentes a las que se hará referencia puntualmente en las siguientes Secciones; aquí sólo se mencionará brevemente que la componente gaseosa de la región NGC 604 presenta una estructura muy compleja de cavidades interconectadas, filamentos, cáscaras en expansión (las más prominentes coinciden con los arcos de emisión nebular observados en la imagen) y regiones con distinto grado de

\footnotetext{
${ }^{19}$ NED: NASA/IPAC Extragalactic Database, en http : //nedwww.ipac.caltech.edu, calcula los valores de extinción galáctica según Schlegel et al. (1998).

${ }^{20}$ http : //www.lowell.edu/users/massey/lgsurvey.html
} 
excitación. En la imagen se han marcado con las letras A-D las cuatro cavidades más importantes y los círculos rojos señalan particularmente las dos principales ( $\mathrm{A}$ y $\mathrm{B}$ ). Las regiones donde se encuentran las componentes más notorias de la SOBA se han identificado con SOBA I y SOBA II. SOBA I corresponde a la componente más importante, la cual se encuentra centrada en la cavidad A y SOBA II corresponde a una componente más dispersa que se extiende sobre una región más amplia hacia el sureste de la cavidad A (para señalar la SOBA y las cavidades se ha seguido la nomenclatura utilizada por Maíz-Apellániz et al., 2004). Las líneas amarillas señalan la posición de las estrellas WR identificadas por distintos autores que se detallarán más adelante. Las líneas celestes marcan la posición de las fuentes candidatas a estrellas supergigantes rojas $\left(\mathrm{RSG}^{21}\right.$ ) del estudio de Barbá et al. (2009) y el círculo verde la estrella clasificada como RSG por Terlevich et al. (1996). Finalmente 'Cúmulo B' señala la ubicación del 'Cúmulo B' considerado en el estudio de Hunter et al. (1996).

\subsubsection{Sobre la componente gaseosa}

Tenorio-Tagle et al. (2000) realizaron un estudio cinemático detallado de la fase gaseosa de NGC 604 a partir del cual concluyeron que la primera generación de estrellas masivas de la región, mediante la enegía mecánica inyectada por sus vientos, rápidamente estructuró la nube formando las cavidades, cáscaras y túneles con la compleja geometría que se observa actualmente. El gas ionizado no se encuentra ocupando todo el volumen de la región HII, sino que la materia de alrededor de las estrellas masivas fue confinada a estructuras bidimensionales en las paredes de dichas cavidades, cáscaras y túneles. La exposición del gas a la radiación de las estrellas masivas causa la apariencia filamentosa características de la región. Tres de las cavidades más importantes de la región (las cavidades A, B y D de la Figura 1.14) se encuentran en expansión en el halo de M33, fenómeno conocido como 'blowout'. Estas cavidades también pudieron expandirse en otras direcciones formando los filamentos que se observan, en proyección, alejados del cúmulo central. El blowout genera que una gran cantidad de fotones UV provenientes de la radiación estelar, escapen de la nebulosa ionizando regiones más extendidas en el halo de M33 y, debido a que una parte importante de la energía escapa hacia el halo de M 33, se espera que la estructura global de la nebulosa sufra pocos cambios durante la evolución de las estrellas que la están excitando. Respecto a la cavidad C, Maíz-Apellániz et al. (2004) sugieren, a partir de la evidencia cinemática y del tipo de estrellas allí observadas, que dicha cavidad es una estructura formada anteriormente a las cavidades A, B y D que ha sido recientemente reionizada.

Del análisis de la distribución de las distintas fases del gas realizado por Maíz-Apellániz et al. (2004), resulta que el gas ionizado en la región central de NGC 604 presenta dos componentes: por un lado, hay gas de alta excitación y alta emisión, ubicado en las superficies de las nubes moleculares expuestas a la radiación ionizante de las estrellas; esta componente presenta una

\footnotetext{
${ }^{21}$ RSG: del acrónimo en inglés de 'Red Super Giant' (supergigante roja).
} 


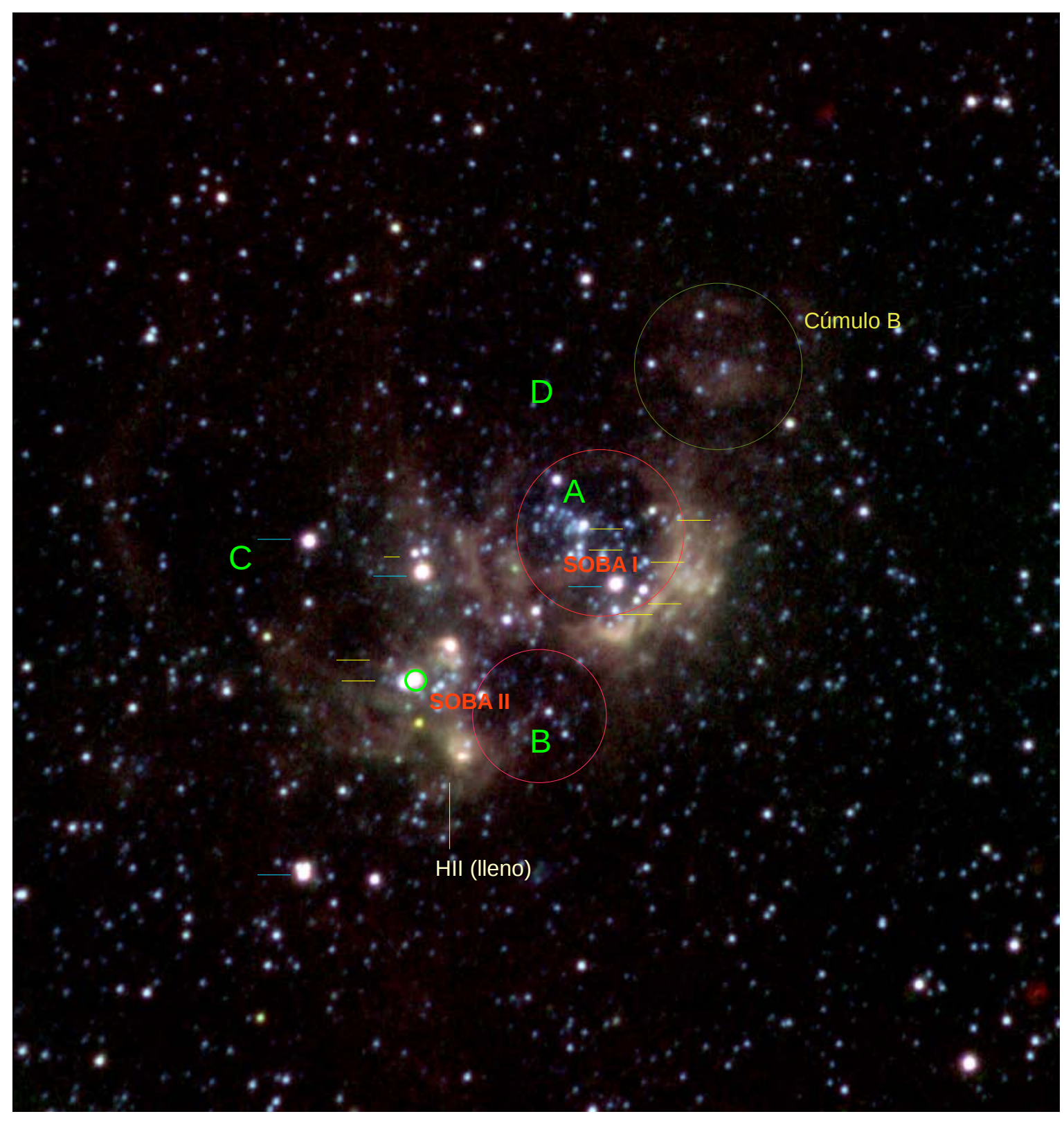

Figura 1.14: Imagen del campo de NGC604 compuesta con las bandas J (azul), H (verde) y Ks (rojo) de las imágenes de Gemini-NIRI utilizadas en esta Tesis. El campo es de $\sim 120^{\prime \prime} \times 120^{\prime \prime}$ $\left(\sim 490 \times 490 \mathrm{pc}^{2}\right)$. En la imagen se han marcado con las letras $A-D$ las cuatro cavidades más importantes y los círculos rojos señalan particularmente las dos principales ( $A$ y B). Las regiones donde se encuentran las componentes más notorias de la SOBA se han identificado con SOBA I y SOBA II. Las líneas amarillas señalan la posición de las estrellas WR. Las líneas celestes marcan la posición de las fuentes candidatas a estrellas RSG del estudio de Barbá et al. (2009) y el círculo verde la estrella clasificada como RSG por Terlevich et al. (1996). 'Cúmulo B' señala la ubicación del 'Cúmulo B' considerado en el estudio de Hunter et al. (1996). La orientación de la imágen es corresponde al norte hacia arriba y el este hacia la izquierda. 
estructura bidimensional denominada 'superficie HII'. La otra componente del gas ionizado es gas difuso de baja excitación y baja intensidad, que se extiende por cientos de parsecs en toda la región. La distribución del gas de alta y baja excitación no presenta una configuración concéntrica. La estructura del gas en el halo se asemeja una serie de cáscaras delgadas, similar a la observada en 30 Dor.

Thilker (2000) mostró que adyacente a NGC 604, hacia el sureste, hay una burbuja de $\mathrm{HI}$ cuyo centro está ubicado aproximadamente a 1 kpc de NGC 604. Maíz-Apellániz et al. (2004) observan que las cavidades de NGC 604, en general presentan un diámetro menor al esperado considerando que son generadas por la contribución de energía de más de 200 estrellas 0 durante aproximadamente $3 \times 10^{6}$ años, y argumentan que esto podría ser consecuencia de que el gas del medio interestelar en NGC 604 no se encuentra en equilibrio de presión, debido a que la burbuja de Hi está generando una presión externa que impide la expansión de las cavidades. También se plantea la hipótesis de que la burbuja de Hi habría sido el agente generador del primer brote de formación estelar en NGC 604.

La cinemática del medio interestelar de la región también fue estudiada por Yang et al. (1996), incluyendo la emisión en $\mathrm{X}$ del gas difuso. Los autores concluyen que el ancho del perfil de velocidad integrado es el resultado de la contribución del ancho debido a movimiento térmico más el ensanchamiento debido a los vientos estelares y a remanentes de supernovas $\left(\mathrm{SNR}^{22}\right)$ más el movimiento virial.

La Figura 1.15 muestra, en el panel izquierdo, la ubicación de las nubes moleculares derivada de observaciones de $\mathrm{CO}$ con una resolución espacial de 13", pertenecientes al estudio realizado con BIMA sobre M 33 por Engargiola et al. (2003). La emisión de CO fue estudiada anteriormente por Viallefond et al. (1992), con una resolución de $12^{\prime \prime}$ y $24^{\prime \prime}$ para ${ }^{12} \mathrm{CO}$ y ${ }^{13} \mathrm{CO}$, quienes observan 2 nubes a las cuales les calculan una temperatura $\mathrm{T}=12 \mathrm{~K}$, una densidad $\mathrm{n}_{H_{2}}=10^{3} \mathrm{~cm}^{-3}$ y una masa $\mathrm{M}=10^{3} \mathrm{M}_{\odot}$ en cada nube.

El panel derecho de la Figura 1.15 muestra la emisión en $X$; puede verse que la emisión en $\mathrm{X}$ difusa aparece llenando las 4 cavidades. La fuente puntual más intensa ubicada hacia el sur coincide con el SNR detectado por Dodorico et al. (1980). La emisión en X es blanda $\left(\mathrm{L}=8 \times 10^{38} \mathrm{erg} \mathrm{s}^{-1}\right)$ y está fundamentalmente dominada por un plasma caliente pero delgado energizado por los vientos estelares, es decir gas coronal (Yang et al., 1996). Las dos imágenes de la Figura 1.15 fueron tomadas de Maíz-Apellániz et al. (2004).

Churchwell \& Goss (1999) han estudiado la componente gaseosa de NGC 604 mediante observaciones de VLA en el continuo de radio en $8.44 \mathrm{GHz}(3.6 \mathrm{~cm})$, con una resolución espacial de $2^{\prime \prime}(\sim 8 \mathrm{pc})$. Estas observaciones les permitieron distinguir seis nudos de radio inmersos en un halo más tenue y extendido. La Figura 1.16 muestra la imagen de los contornos de emisión en radio de la mencionada publicación. Cada máximo de emisión requiere el equivalente a 5-8 estrellas $05 \mathrm{III}$ para generar la emisión observada. La densidad electrónica en los nudos más

\footnotetext{
${ }^{22}$ SNR: del acrónimo en inglés de 'Supernova Remnant' (remanente de supernova).
} 


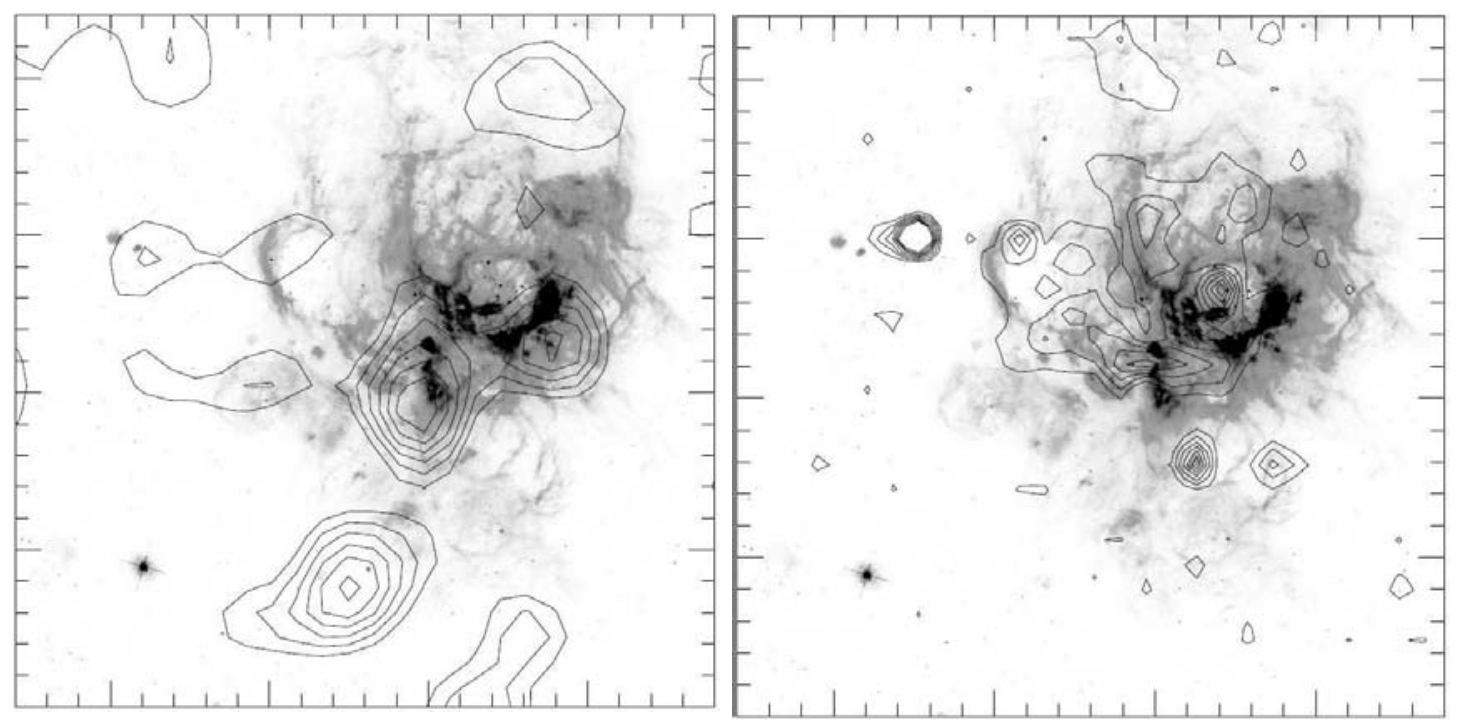

Figura 1.15: Panel izquierdo: ubicación de las nubes moleculares (observaciones de CO) sobre

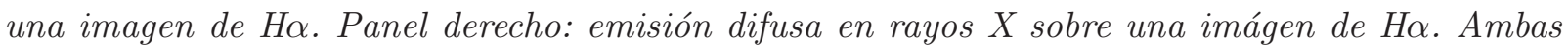
imágenes se orientan con el norte está hacia arriba y el este a la izquierda. Ambas imágenes fueron tomadas de Maíz-Apellániz et al. (2004).

intensos ( $\mathrm{A}$ y $\mathrm{C}^{23}$ de la Figura 1.16) es de $\mathrm{n}_{e} \sim 100 \mathrm{~cm}^{-3}$. La masa total del gas ionizado en la región es de $3 \times 10^{6} \mathrm{M}_{\odot}$. En este estudio también calculan la extinción de la región, obteniendo valores de $A_{V}=0.5 \mathrm{mag}$ (en promedio para toda la nebulosa) y $\mathrm{A}_{V}=1.7-2.8 \mathrm{mag}$ en las zonas de los picos de emisión, esto indica que el polvo se encuentra físicamente asociado y mezclado con el gas ionizado (el polvo puede ser remanente de la nube originaria más una contribución proveniente de la fotoionización de los discos de acreción asociados a estrellas del cúmulo).

Diaz et al. (1987) realizaron una determinación precisa de la composición química del gas de la región y obtuvieron una metalicidad similar a la de 30 Dor, con valores de $Y=0.26 \pm 0.013$ (abundancia de He por masa). Vilchez et al. (1988) obtuvieron valores de $Z=0.4 Z_{\odot}$.

\subsubsection{Sobre la componente estelar}

La población estelar de masa intermedia-alta de NGC 604 fue estudiada por Hunter et al. (1996), quienes mediante fotometría de objetos individuales con imágenes de $\mathrm{HST}^{24}$ (en los filtros F336W, F555W y F814W), observaron objetos hasta un límite inferior de $6 \mathrm{M}_{\odot}$. Los autores reportan un total de 186 estrellas $\mathrm{O}$ (hasta $09.5 \mathrm{~V}$ ) en el 'Cúmulo A', el cual cubre

\footnotetext{
${ }^{23}$ En la presente Tesis se ha decidido seguir la nomenclatura utilizada originalmente en los distintos estudios de NGC 604 para señalar sus componentes. Vale aclarar entonces, que si bien los nudos de emisión en continuo de radio en $8.44 \mathrm{GHz}$ (Churchwell \& Goss, 1999) se identifican con las mismas letras que las cavidades principales de la región (Maíz-Apellániz et al., 2004) se refieren a estructuras diferentes.

${ }^{24}$ HST: Hubble space Telescope.
} 


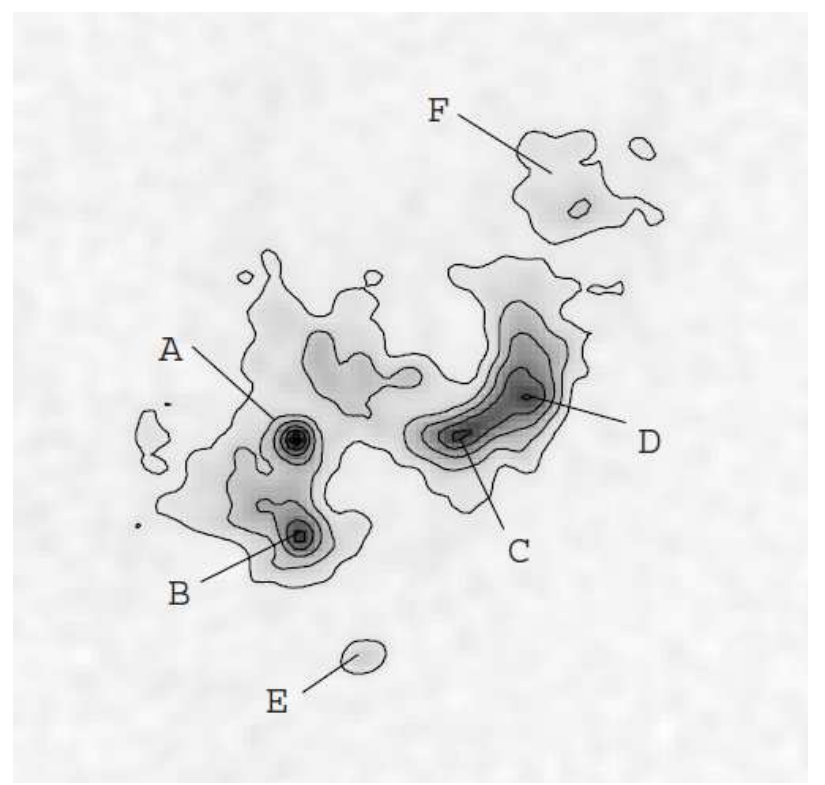

Figura 1.16: Imagen de los contornos de emisión en radio en $8.44 \mathrm{GHz}$, adaptada de Churchwell $\mathscr{G}$ Goss (1999). La imagen se orienta con el norte está hacia arriba y el este a la izquierda.

un área de $\sim 10000 \mathrm{pc}^{2}$, abarcando los objetos pertenecientes a las SOBA I y II de la Figura 1.14. También reportan 8 estrellas $O$ en la región del 'Cúmulo B' (señalado en la Figura 1.14). Por otro lado detectan objetos muy luminosos, probablemente RSG. Los autores calcularon la IMF para masas estelares en el rango de $\mathrm{M}=6.5-18 \mathrm{M}_{\odot}$, derivando un valor para la pendiente de $\beta=-1.6 \pm 0.7$ (similar a la de las asociaciones OB galácticas dentro del error). También la densidad estelar de objetos brillantes es comparable con la medida en las asociaciones OB galácticas.

Drissen et al. (1993) calcularon la IMF para masas estelares en el rango de $\mathrm{M}=15-60 \mathrm{M}_{\odot}$ y obtuvieron un índice $\beta=-1.88 \pm 0.16$ (con menor pendiente que la de Salpeter).

En Miskey \& Bruhweiler (2003) y Bruhweiler et al. (2003) se estudió un sector de la componente estelar masiva pero a un nivel más detallado, mediante espectros UV individuales (tomados con HST-STIS) de 40 estrellas de NGC 604. La mayoría de los objetos que clasificaron son estrellas de tipo espectral O y B (algunas tan jóvenes como O3 -O4), y tres objetos podrían ser estrellas WR u Of con masas estelares mayores a $120 \mathrm{M}_{\odot}$. Los autores infieren que la edad característica del cúmulo es de $3 \times 10^{6}$ años (al igual que Maíz-Apellániz, 2000). Y con las 30 estrellas OB más brillantes calcularon un valor para el índice de la IMF, $\beta=-2.3$.

Los resultados mencionados previamente son coincidentes con los que obtuvieron González Delgado \& Pérez (2000) usando espectros de la emisión nebular de la región en el óptico y UV más modelos de evolución optimizados para regiones de formación estelar. Los autores de este estudio derivaron el contenido estelar y el estado evolutivo del cúmulo central a partir de la emisión integrada de la región y contrastaron sus resultados con los datos existentes derivados 
de forma más directa. En dicho estudio, obtuvieron que el cúmulo central ionizante tiene una población de 150-200 estrellas O y una edad de $3 \times 10^{6}$ años, con una IMF de Salpeter o más achatada $(\beta=1.5)$ y cuya población estelar contiene estrellas más masivas que $80 \mathrm{M}_{\odot}$. El radio determinado por el frente de ionización se extiende hasta 110 pc y contiene gas ionizado muy tenue $\left(\mathrm{n}_{e} \sim 30 \mathrm{~cm}^{-3}\right)$, con un factor de llenado de 0.1 . La extinción que afecta al cúmulo estelar es baja: $\mathrm{E}_{(B-V)}=0.1-0.2$ dependiendo de la ley de extinción utilizada. Los autores concluyeron que la energía cinética del viento proveniente de las estrellas masivas es suficiente para formar la burbuja central donde se ubica el cúmulo, pero no es suficiente para provocar la formación de las estructuras tipo cáscara observadas en la emisión de $H \alpha$.

Como es esperable en GHRs, varios estudios observacionales en NGC 604 han detectado características de la emisión de estrellas WR. Empezando por Conti \& Massey (1981), quienes en un estudio dedicado a la búsqueda de estrellas WR en M 33, detectaron por primera vez 3 estrellas WR en NGC 604 (las observaciones que utilizaron fueron adquiridas con una abertura de 5.3" de diámetro, en un rango espectral entre $\lambda=3300 \AA$ y $\lambda=5100 \AA$ y con una resolución de $10 \AA ̊$ ). Por esa misma época Rosa \& Dodorico (1982), Dodorico \& Rosa (1981) también identificaron emisión de estrellas WR. Posteriormente Drissen et al. (1993) realizaron un estudio del contenido de estrellas WR en NGC 604 y NGC 595 con imágenes de HST-WFPC2 y detectaron 14 candidatas a estrellas WR u Of; en sus observaciones algunas de las estrellas WR encontradas por Conti \& Massey (1981) fueron resueltas como pequeños cúmulos compactos de estrellas. En ese mismo estudio calcularon que las estrellas WR son las mayores contribuyentes de energía mecánica al medio interestelar en la región. Finalmente, en Drissen et al. (2008) clasificaron espectroscópicamente 13 estrellas WR en NGC 604, 5 de las cuales eran estrellas WR ya conocidas.

Terlevich et al. (1996) encontraron una estrella RSG a partir de las líneas de absorción T del Calcio (CaT). En el mismo estudio, los autores clasificaron un objeto como un estrella en transición entre una Variable Luminosa Azul $\left(\mathrm{LBV}^{25}\right)$ y una WR. Dicha fuente exhibía líneas espectrales excepcionalmente anchas $\left(\sim 2500 \mathrm{~km} \mathrm{~s}^{-1}\right)$, sobreabundancia de He y una variabilidad espectral importante en escalas de tiempo de $\sim 10$ años. También observaron emisión característica de estrellas WR en diferentes zonas de la región.

\subsubsection{Sobre la nueva generación de estrellas}

Tosaki et al. (2007) estudiaron la componente molecular de NGC 604 mediante observaciones de las transiciones $\mathrm{J}=1-0$ y $\mathrm{J}=3-2$ del $\mathrm{CO}$, con una resolución espacial de $25^{\prime \prime}$. El cociente $\mathrm{CO}(\mathrm{J}=3-2) / \mathrm{CO}(\mathrm{J}=1-0)$ toma valores entre $0.3-1.2$ y la zona en que dicho cociente es máximo corresponde a un arco coincidente con la cáscara de HiI que se extiende a lo largo de $\sim 200$ pc, desde el sureste hacia el noreste de la región. El cociente $\mathrm{CO}(\mathrm{J}=3-2) / \mathrm{CO}(\mathrm{J}=1-0)>1$ indica temperaturas $\mathrm{T}>60 \mathrm{~K}$ y densidades $\mathrm{n}_{H_{2}}>10^{3}-10^{4} \mathrm{~cm}^{-3}$, es decir, gas comprimido, de altas

\footnotetext{
${ }^{25}$ LBV: del acrónimo en inglés de 'Luminous Blue Variable' (variable luminosa azul).
} 
densidades y tibio. Los autores afirman que dicho gas presenta las condiciones adecuadas para albergar la siguiente generación de estrellas en NGC 604, y proponen un escenario de formación estelar secuencial, donde una segunda generación de estrellas es actualmente inducida en dichas zonas por la compresión del gas generada por vientos estelares de las estrellas masivas ya formadas. Dicho escenario ha sido respaldado en un estudio recientemente publicado por Miura et al. (2010), quienes disponían de datos de CO con mayor resolución espacial (5.4"), junto con observaciones de HCN y continuo de radio en $89 \mathrm{GHz}$. Miura et al. distinguieron en particular tres nubes de $\mathrm{CO}$, las cuales presentan una correlación espacial y de velocidad con las cáscaras de $H \alpha$. Al calcular las tasas de eficiencia de formación estelar para cada nube encontraron una dependencia con la distancia radial al centro de la cavidad principal, además observaron que los picos de emisión de HCN y $89 \mathrm{GHz}$ muestran un corrimiento en dirección al cúmulo central con respecto a los máximos de emisión de $\mathrm{CO}$ e interpretaron todos estos factores como evidencia del diferente estadio de evolución de las nubes moleculares, derivando de ello un escenario de formación secuencial coincidente con el propuesto por Tosaki et al. (2007).

En menor escala espacial, Maíz-Apellániz et al. (2004) plantearon explícitamente la posibilidad de encontrar formación estelar inducida en la región señalada como 'HII (lleno)' en la Figura 1.14, que es una región HII 'compacta' y la más brillante de NGC 604.

El estudio realizado en esta Tesis forma parte de un amplio proyecto para estudiar la componente estelar de la región de NGC 604 en forma integral. Dicho proyecto cuenta también con imágenes tomadas con HST (NICMOS y ACS-HRC). Una parte de los resultados obtenidos del análisis de las imágenes de HST-NICMOS fue publicada por Barbá et al. (2009). En el estudio fotométrico realizado con dichas imágenes se identifican objetos candidatos a MYSOs corroborando lo obtenido con las imágenes de banda ancha de Gemini-NIRI (que será presentado en el Capítulo 3); también se detectaron cinco fuentes candidatas a RSG (los objetos más brillantes del campo en la banda K, marcados con las líneas celestes en la Figura 1.14). 



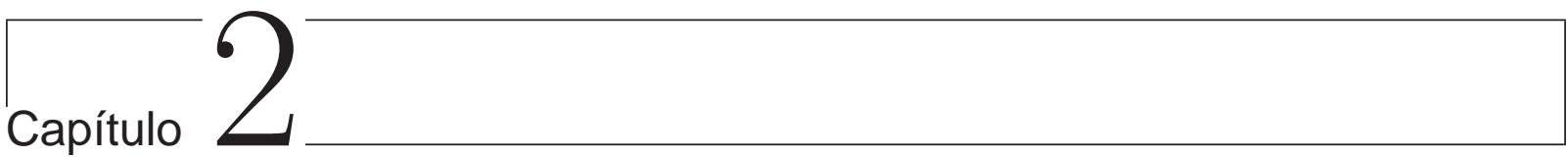

\section{Observational data and data handling}

\subsection{Introduction}

This Chapter is dedicated to review the most important issues related to the data handling performed for the study of this Thesis.

The Sections that constitute this Chapter are: $\bullet$ Gemini-NIRI: a brief instrument description: presents a description of the instrument Gemini-NIRI used to acquire the images for this Thesis; - Observational data: the proposal: presents a description of the observing proposal. The following Sections conform a detailed exposition of all the work done from the raw images to the final photometry table in the standard magnitudes system. The Sections are following the order in which each stage of the work was made. • Basic raw image corrections: tells about basic raw image corrections; $\bullet$ Reduction process: IRAF tasks: about the image reduction process and also includes comments on the image quality; • The astrometry: describes the work done to perform the astrometric solution; • Point spread function photometry: explains in detail the procedure to perform $\mathrm{PSF}^{1}$ photometry; • The ' $\chi$ problem': is devoted to explain what I have called 'the $\chi$ problem' regarding to the goodness of fit statistic ' $\chi$ '; $\bullet$ To the standard system photometry: describes the transformation to the standard MKO photometric system.

The work and analysis described in this Chapter constitutes, in my personal opinion, one of the knots of the present Ph.D Thesis from the learning point of view. Several things that in this Chapter are explained in a clear and logical way took many hours of study, work, and trials and re-doing to obtain good and reliable results.

\footnotetext{
${ }^{1}$ PSF: acronym from Point Spread Function.
} 



\subsection{Gemini-NIRI: a brief instrument description}

The images used for the present study were acquired with NIRI at Gemini-North Telescope (8.1-m), located in Mauna Kea, Hawaií. NIRI, which name is derived from the acronym of Near Infrared Imager and Spectrometer, is an instrument that works in the NIR wavelength range (1-5 $\mu \mathrm{m})$ providing photometric and spectroscopic images. Its detector is an InSb ALADDIN-II array of $1024 \times 1024$ pixels, being the individual pixel size of $27 \times 27 \mu \mathrm{m}^{2}$. NIRI provides the possibility to choose between three cameras with different focal length, which determine the plate scale and field of view to be obtained. Table 2.1 lists the cameras and the image characteristics obtained with them.

\begin{tabular}{ccc}
\hline Camera & $\begin{array}{c}\text { Pixel Size } \\
\left(\operatorname{arcsec~pxl}^{-1}\right)\end{array}$ & $\begin{array}{c}\text { Field of View } \\
\left(\operatorname{arcsec}^{2}\right)\end{array}$ \\
\hline $\mathrm{f} / 6$ & 0.1171 & $119.9 \times 119.9$ \\
$\mathrm{f} / 14$ & 0.0499 & $51.1 \times 51.1$ \\
$\mathrm{f} / 32$ & 0.0219 & $22.4 \times 22.4$ \\
\hline
\end{tabular}

Table 2.1: Pixel sizes and fields of view obtained with the three different cameras available at NIRI.

There are 33 filters available to be used for NIRI imaging, 9 of them are broad-band filters ( $Y, J, H, K, K s, K^{\prime}, L^{\prime}, M^{\prime}$, and $H-K$ notch) and 23 are narrow-band and continuum filters which central wavelengths range from 1.065 to $4.052 \mu \mathrm{m}$. Details of these filters can be found at NIRI's web page http://www.gemini.edu/sciops/instruments/niri/imaging/filters.

A complete description and more specific information about NIRI design, optical and mechanical systems, electronics, software, and capabilities can be found at Hodapp et al. (2003). The following paragraphs contain information extracted from the publication mentioned above, aiming to summarize the basic NIRI's characteristics, specially those that highlight the difference between an IR detector and an optical one $\left(C C D^{2}\right)$, paying special attention to those NIRI's characteristics that have an evident imprint in the images used for this study.

\section{NIRI general characteristics}

Table 2.2, transcribed from NIRI's web page, syntheses NIRI's detector characteristics. Some of the properties listed in the table are going to be developed further along this Section and nearly all of them will be referenced at different Sections along this Chapter.

\footnotetext{
${ }^{2}$ CCD: acronym for 'Charge-Coupled Device'.
} 


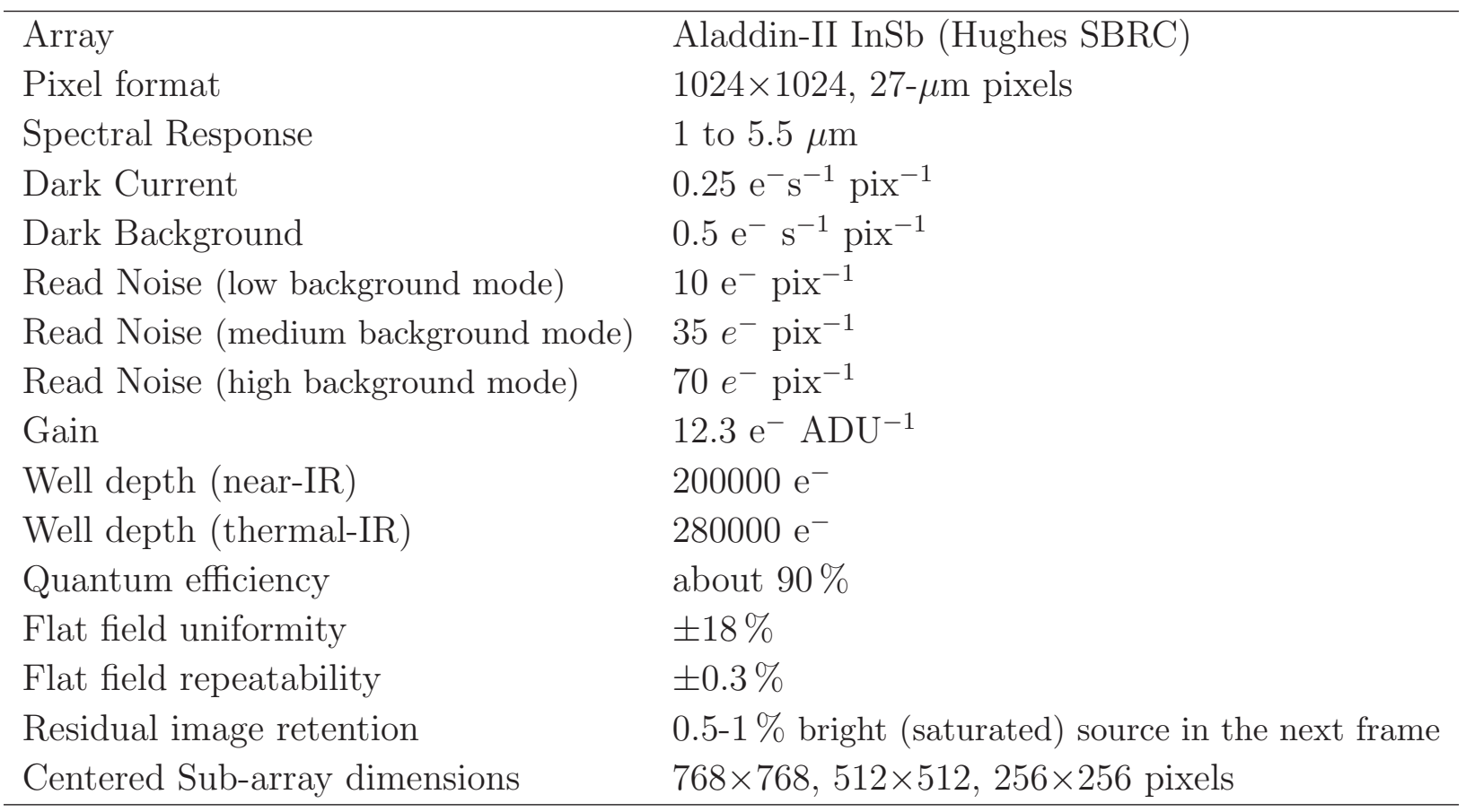

Table 2.2: NIRI's detector main characteristics, transcribed from NIRI's web page: http ://www.gemini.edu/sciops/instruments/niri/imaging? $q=$ node/10128.

\section{The readout system and readout modes}

The ALADDIN readout system has four electrically independent quadrants (in some of the raw images it is possible to distinguish the quadrants when they have slightly different initial potential). Each quadrant has eight independent parallel video outputs and the pixels in it are read by rows, in groups of eight adjacent columns at a time. This configuration is responsible for the 'vertical striping' pattern that affects the images (see Figure 2.5 and the explanation of 'vertical striping' correction at Section 2.4.1). The four quadrants are read from the outside corners toward the center, to reduce the glow within the array.

One difference among IR detectors and optical CCDs is that the former normaly have not shutter to limit the entrance of light. As NIRI has no shutter the procedure to acquire an image follows this sequence:

- reset charges in the detector (reset)

- read the charges in each pixel immediately after resetting (read_1)

- perform the actual observation of the source (expose)

- when the exposure time ends, perform another reading of the pixel charges (read_2)

- derive true signal for each pixel from the difference between read_2 and read_1 
This simple procedure (reset - read_1 - expose - read_2) is repeated for acquiring each image.

Another important difference with the CCD optical detectors is that IR arrays can be read in a nondestructive way. To 'read' the array (that is, to sense the charge on each pixel) is different than to 'reset' the array (recharge the capacitance at each pixel). Hence, exploiting this advantage, NIRI has a digital filter to reduce the signal bandwidth and reject noise, allowing the read signal to be digitally sampled several times reducing the system noise at the expense of longer readout times.

Since in the NIR regime the image's background can saturate the detector in short exposures, there are three readout modes according to the background emission:

1. For high background the detector is read twice (read_1 before the exposure and read_2 at the end of the exposure) and, to minimize the readout time, no digital averages are made, yielding a read noise of $\sim 100 \mathrm{e}^{-}$.

2. For moderate background and wide field images (as our broad-band JHKs images are) the detector is also read twice but 16 digital averages are made for each reading, thus the read noise obtained is $\sim 45 \mathrm{e}^{-}$.

3. The minimum read noise $\left(\sim 13 \mathrm{e}^{-}\right)$is achieved for low background observations; in this case, the detector is read 16 times and each reading is digitally averaged 16 times.

\section{The first frame image dark current pattern}

The first image after from each dither sequence following a intrument configuration or exposure time change is affected by a large-scale pattern of dark current which CANNOT be removed with the flat correction. Hence, every time a new observation series starts after any minor change, the first image of the series must be discarded, as it will be contaminated by the dark current pattern. Figure 2.1 shows a $K s$ image (after reduction) which exhibits the large-scale dark current pattern. Some issues concerning this effect will be further described in Section 2.5.1.

\section{The array's cosmetics}

Figure 2.2 shows a flat image taken with the $\mathrm{H}$ filter. The scale has been expanded and set in logarithms to enhance the array's cosmetics. The most evident array defects are marked with colored contours: on the top left corner there are two groups of bad pixels (green circles), the array has a diagonal crack in the lower right corner (blue ellipse), and there are three locations with a several dead pixels (red contours) from which two of them (the ellipses) are followed by a fraction of column with dead pixels. Apart from these features the array exhibits good 

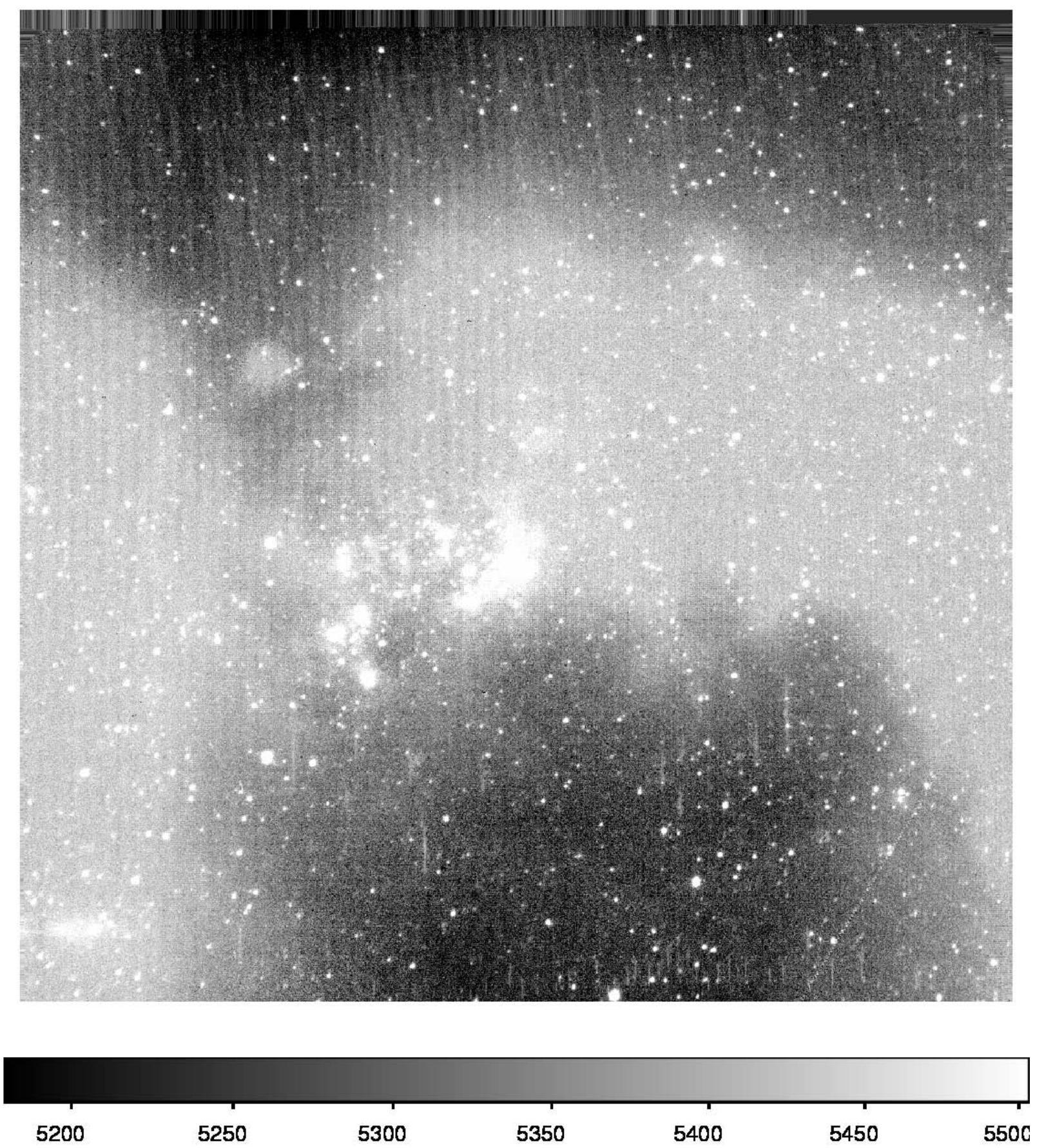

Figura 2.1: First series Ks image exhibiting the dark current pattern. 
cosmetics, being the total number of bad working pixels of $\sim 0.1 \%$ of the total array's pixels. The vertical arc pattern dominant in the flat field image is inherent to the array itself and is present in all the raw images, it was originated in the array's fabrication process and can be removed from the data images when they are divided by the flat field image. The dark current is $0.3-0.5 \mathrm{e}^{-} \mathrm{s}^{-1}$ (being the sky background much higher than these values). Another important detector characteristic is the repeatability: the flat image must be repeatable and should not exhibit large variations with time and physical conditions; the flat field repeatability for NIRI is $\pm 0.3 \%$.

\subsection{Observational data: the proposal}

As was mentioned before, the study presented here is based on the analysis of photometric images acquired with the Frederick C. Gillet, 8.1-m telescope from Gemini Observatory, located at Mauna Kea, Hawaií.

The proposal (GN-2005B-Q-3, PI: Dr. Guillermo Bosch) was awarded time on Band-1 for the semester 2004B in the queue observing mode. Bad weather conditions at Mauna Kea prevented it from being observed during that semester. Therefore, the proposal was re-submitted for the 2005B semester, being again awarded 6.33 hours on Band-1, and in this opportunity it was observed.

The proposal consisted of photometric observations towards NGC 604, using NIRI in its imaging mode with broad-band $\left(\mathrm{J}, \mathrm{H}\right.$, and $\mathrm{Ks}$ ) and narrow-band $\left(\mathrm{Br} \gamma, \mathrm{Pa} \beta\right.$, and $\left.\mathrm{H}_{2}\right)$ filters, without adaptive optics. Table 2.3 lists each of the filters used together with the central wavelength and the wavelength coverage in columns 1, 2, and 3, respectively. Figure 2.3 is the graphic version of Table 2.3. In this figure the filter's transmission curves were graphically reproduced from the numerical transmission data available at NIRI's web page.

As was explain in Chapter 1 , in the NIR wavelength range, the sky background level is high and variable on short time scales. Therefore, sky images are required to generate a sky template and subtract it from science images. The sky template can be generated using the science images for isolated point sources, whereas in the case of extended objects or crowded fields, it is necessary to specially acquire sky frames. The sky frames must be acquired between the science images by making telescope offsets to nearby and, as empty as possible, positions in the sky. The sky images must be taken exactly with the same conditions as the science field images, being the exposure time the same for both sky and science images.

For this proposal, the NGC 604 science field was centered at $\alpha=01^{h} 34^{m} 32^{s} .35, \delta=+30^{\circ} 47^{\prime} 04^{\prime \prime} .00$ (J2000.0), and the center of the sky frame was shifted $\Delta \delta \sim 3^{\prime} .30$ to the north.

Both sky and science images were acquired with the dithering method, which consists in 

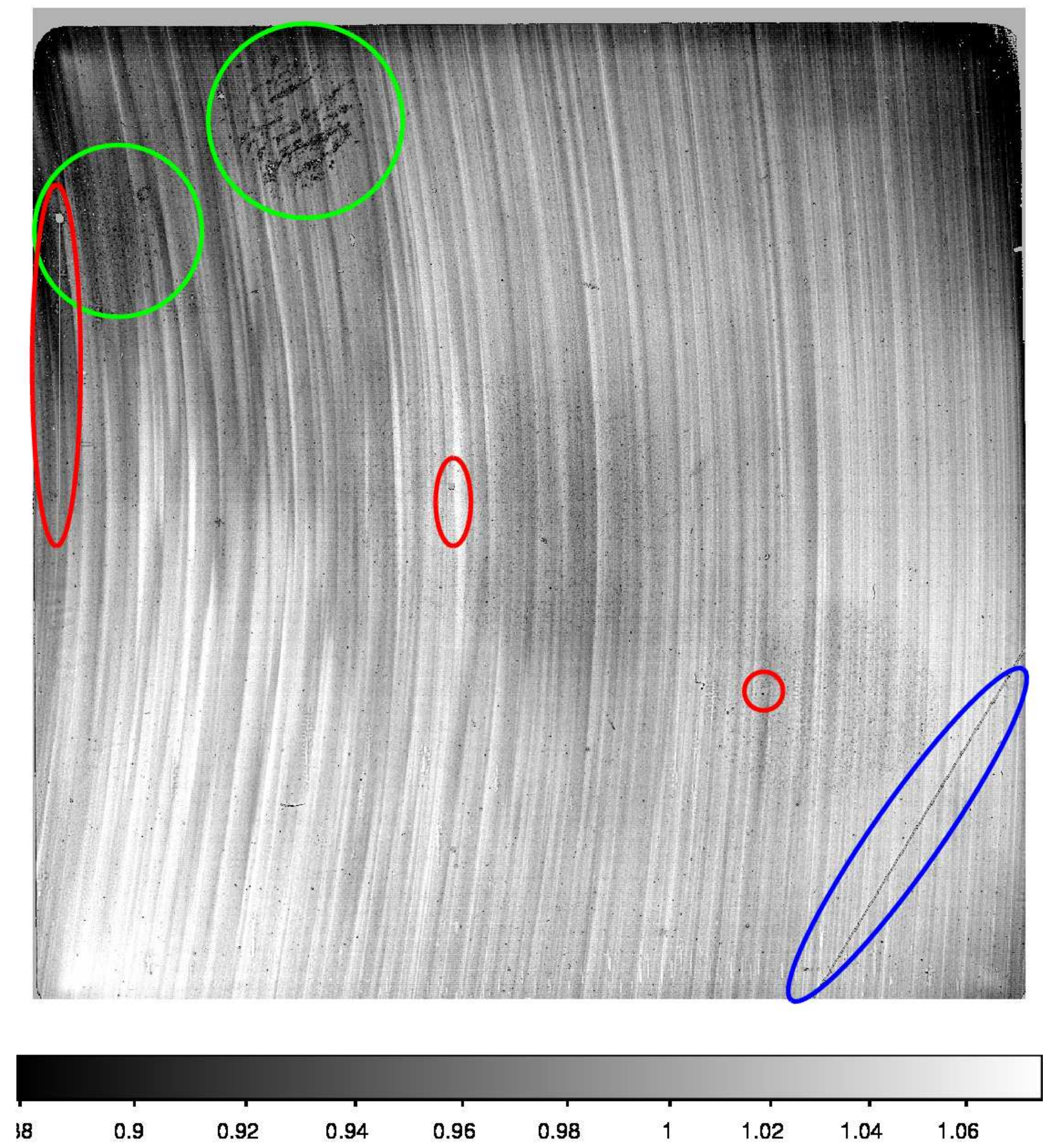

Figura 2.2: $H$ filter flat image. The color scale was expanded to enhance the flat characteristics. The most evident array defects are marked with colored contours: on the top left corner there are two groups of bad pixels (green circles), the array has a diagonal crack in the lower right corner (blue ellipse), and there are three locations with several dead pixels (red contours) from which two of them (the ellipses) are followed by a fraction of column with dead pixels. 


\begin{tabular}{ccc}
\hline Filter & $\lambda_{c}(\mu \mathrm{m})$ & Coverage $(\mu \mathrm{m})$ or $\delta \lambda / \lambda(\%)$ \\
\hline$J$ & 1.25 & $1.15 .-1.33$ \\
$H$ & 1.65 & $1.49-1.78$ \\
$K s$ & 2.15 & $1.99-2.30$ \\
$P a \beta$ & 1.282 & $1.5 \%$ \\
$B r \gamma$ & 2.168 & $1.36 \%$ \\
$H_{2}(2-1)$ & 2.246 & $1.34 \%$ \\
\hline
\end{tabular}

Table 2.3: Main characteristics of broad-band and narrow-band filters used in our Gemini-NIRI observations.

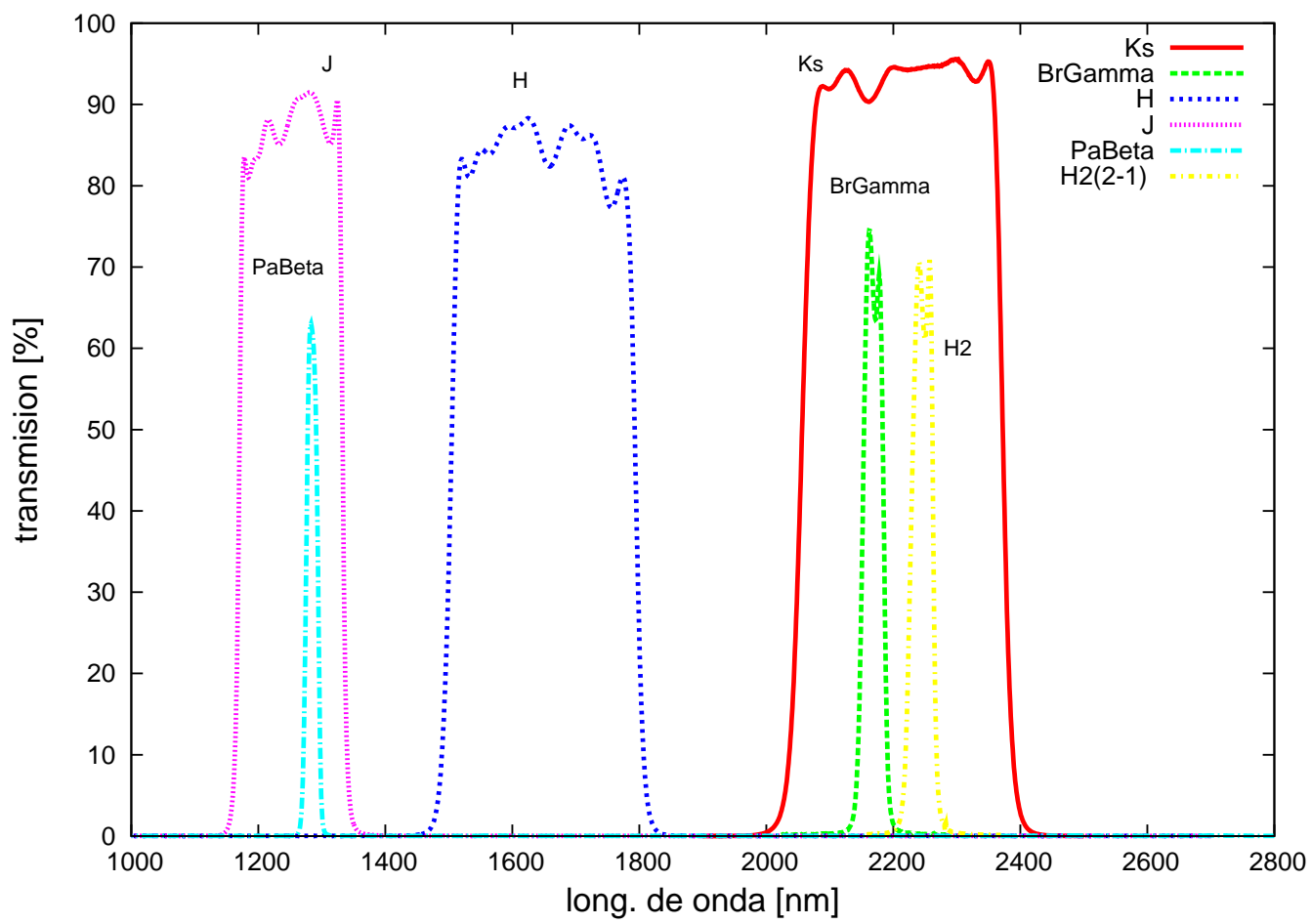

Figura 2.3: Filter set transmission curves reproduced from the numerical transmission data available at NIRI's web page. 

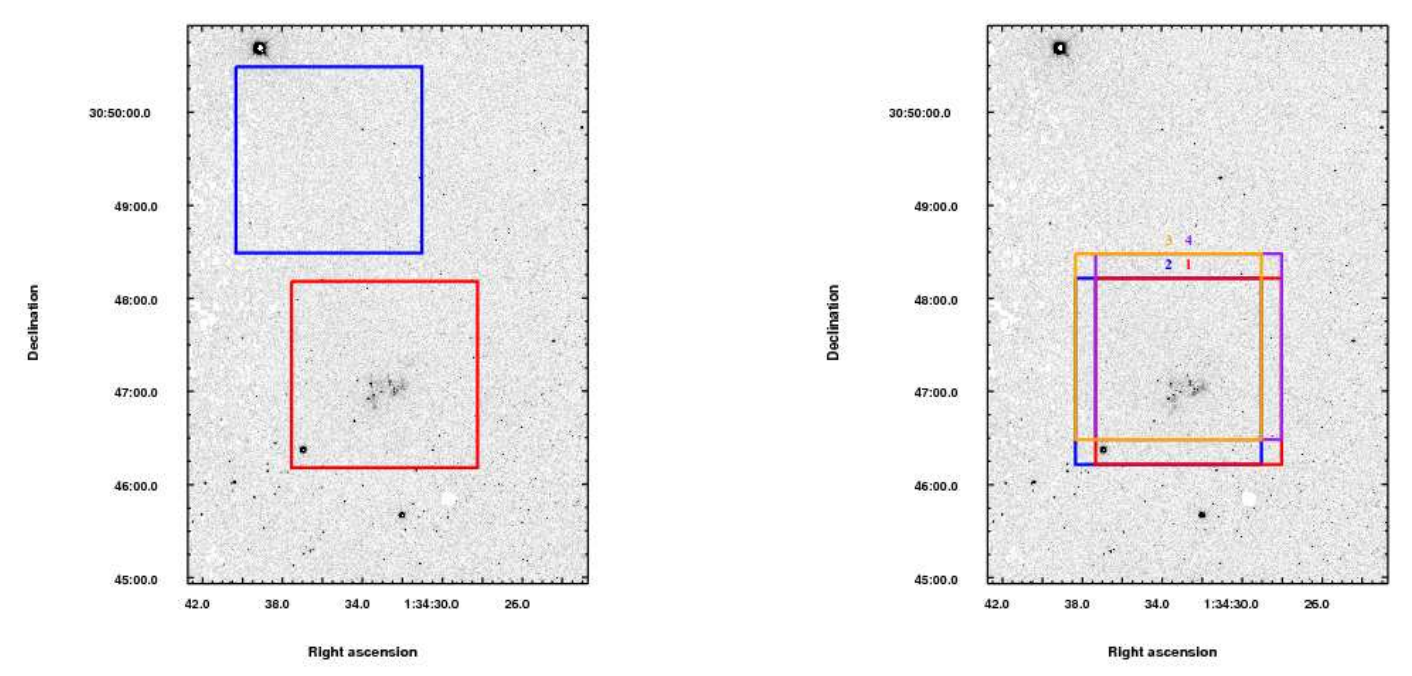

Figura 2.4: Left panel shows - superimposed over a wide frame in the J-band taken from The Canadian Astronomy Data Centre (CFHT) Science Data Archive - the approximate loci of NGC604 science frames (red square) and the sky frames (blue square). Right panel shows an schematic view of the four dithering position for the NGC604 field.

making small displacements between images of the same field to achieve a better correction of bad pixels and other artifacts when the images are combined. The displacements were made in such a way that if we consider the position of a reference object within the field, after eight (for broad-band) and four (for narrow-band) images, the reference object was located at the four corners of a 85 pixel square with respect to a fix reference frame.

In Figure 2.4, the left panel shows the approximate loci of NGC 604 science frames (red square) and the sky frames (blue square). Right panel shows a schematic view of the four dithering positions for the NGC 604 field. The NGC 604 and sky frames are superimpose over an image in the $J$-band, taken from The Canadian Astronomy Data Centre (CADC) Science Data Archive.

The sky fields (s) and NGC 604 science fields (s) images were acquired following the sequence:

- For the broad-band images: $1 s-2 f-2 s-2 f-4 s-2 f-2 s-4 f-2 s-2 f-4 s-2 f-2 s-2 f$ From this series we did not receive $1 \mathrm{f}$ in the $J$ filter and $2 \mathrm{f}$ in the $K s$ filter.

- For the narrow-band images: $1 s-1 f-1 s-1 f-2 s-1 f-1 s-2 f-1 s-1 f-2 s-1 f-1 s-1 f$

Table 2.4 summarizes the information related to the data used for this Thesis. For each filter, dates when the images were acquired are detailed in Column 2; Columns 3 and 4 list the total number of sky and science images, respectively and, between parenthesis, the total 


\begin{tabular}{cccccc}
\hline Filter & Observing night & Sky & Field & Exp. Time (s) & Standard \\
\hline$J$ & $2005 / 09 / 08$ & $17(16)$ & $15(14)$ & 120.0 & $5(\mathrm{FS} 104)$ \\
$H$ & $2005 / 09 / 11$ & $17(16)$ & $16(16)$ & 60.0 & $5(\mathrm{FS} 05)$ \\
$K_{s}$ & $2005 / 09 / 08$ & $17(16)$ & $14(14)$ & 40.0 & $5(\mathrm{FS} 05)$ \\
$P a \beta$ & $2005 / 09 / 07$ & $9(8)$ & $8(8)$ & 225.0 & $5(\mathrm{FS} 05)$ \\
$B r \gamma$ & $2005 / 12 / 26$ & $9(7)$ & $8(6)$ & 225.0 & $5(\mathrm{FS} 104)$ \\
$H_{2}(2-1)$ & $2005 / 09 / 07-11$ & $9(8)-4(3)$ & $8-4(6)$ & 225.0 & $5-5(\mathrm{FS} 05)$ \\
\hline
\end{tabular}

Table 2.4: Observations' general information. For each filter, dates when the images were acquired are detailed in Column 2; Columns 3 and 4 list the total number of sky and science images, respectively and, between parenthesis, the total number of 'usable' images; exposure times are shown in Column 5; the number of standard stars images with the star's name between parenthesis are listed in Column 6.

number of 'usable' ${ }^{3}$ images; exposure times are shown in Column 5; the number of standard stars images with the star's name between parenthesis are listed in Column 6.

For each night there were also acquired, as baseline calibration images, 12 lamp-on flats, 12 lamp-off flats, and a series of dark images with different exposure times, from which we used only the short dark images of 2.0 seconds to generate the bad pixel masks (see next Section). There were no dark images available for the nights of 2005/09/11 and 2005/12/26, so the darks of 2005/09/08 and 2005/12/29 nights were used, respectively. This did not introduce any source of uncertainty since the dark images were only used to flag the bad pixels which, except for rare temporary events, lay in the same place within the detector. The standard stars observations were also included in the baseline calibrations delivered by Gemini. As explained before, the proposal was observed in the queue mode and it was split in four observing nights, and the standard stars were observed only with the filters used in the science images at each night, which means that it was not possible to include color terms in the transformation equations. Although it turned to be unnecessary at the end (as it will be explained in detail in the following Sections) it was a far from a good observing strategy.

The images were acquired under excellent seeing conditions, being the full-width half maximum (FWHM) measured in $K s$-band images of $\sim 0.35$ arcsec.

The Gemini-NIRI images are multi-extension FITS (MEF) files which contain one general image header together with the image plane and other planes as the variance plane (VAR) and data quality plane (DQ), each one with its own header. Some of these planes were lost after running some of the IRAF tasks which are not yet updated to deal with MEF files.

\footnotetext{
${ }^{3}$ The term 'usable' utilized in the data description of Gemini's images, does not always means 'good quality', see Section 2.5.1 for further explanation.
} 


\subsection{Basic raw image corrections}

The image processing starts with two fundamental corrections on the raw images: the vertical striping correction and the non-linearity correction. At the moment I started to work with the NIRI images, at the beginning of 2007, these two corrections were not reported to be necessary and there was not even a single mention about them at Gemini-NIRI's web pages. Three years later, at the beginning of 2010, Gemini staff ascertained the necessity to perform these corrections and made available at NIRI's web pages two Python routines to do it. At that moment, all the images were re-reduced including these corrections and the PSF photometry was performed again from scratch in the new corrected images.

\subsubsection{Vertical striping correction}

Most of the NIRI images exhibit a vertical striping pattern which is originated by the array's electronics. Although the spatial profile of the vertical striping pattern is well known (eight columns wide) its intensity varies from one exposure to another and, within an individual image, it is different among the four image quadrants (since each quadrant is read independently).

The vertical striping correction is performed by a Python routine called NIRINOISE.PY ${ }^{4}$.

The routine NIRINOISE.PY was applied to all the images (field images, sky images, flat on/off images, and dark images) in order to remove the vertical striping pattern. Although many tries were done running NIRINOISE with different options, in some images it was not possible to remove the pattern completely. Whereas the vertical striping pattern is not really intense in $\mathrm{ADU}^{5}$, it is a pattern of high spatial frequency and it may affect the photometry. For this reason the few images for which the pattern was not properly removed were discarded.

Figure 2.5 shows, in the left panel, a $K s$ image after the flat-fielding correction but before the vertical striping correction was applied. The right panel exhibits the same image, divided by flat field and corrected by vertical striping using NIRINOISE routine. Both images are displayed exactly with the same scale to allow a faithful visual comparison. Figure 2.6 shows the vertical striping pattern derived by the task NIRINOISE.PY which was used to correct the image shown in the previous figure. Before 2010, several images that look like the one in the left panel were discarded, but after the vertical striping correction most of those images became usable.

In the right panel of Figure 2.5 is still possible to see a slightly different offset in the bias values between the four quadrants. According to NIRINOISE's description at the web page, this offset can also be removed by the routine if it is run with the '- $b$ ' flag, which allows the routine to attempt to iteratively determine and match median value for each quadrant. Unfortunately, this method did not work well in our images since there is large extended nebular emission in the frame. The offset bias between the quadrants was not totally removed in some images.

\footnotetext{
${ }^{4}$ NIRINOISE.PY is provided by Gemini at http ://staff.gemini.edu/ astephens/niri/patternnoise/.

${ }^{5}$ ADU: Analog-to-Digital Unit.
} 

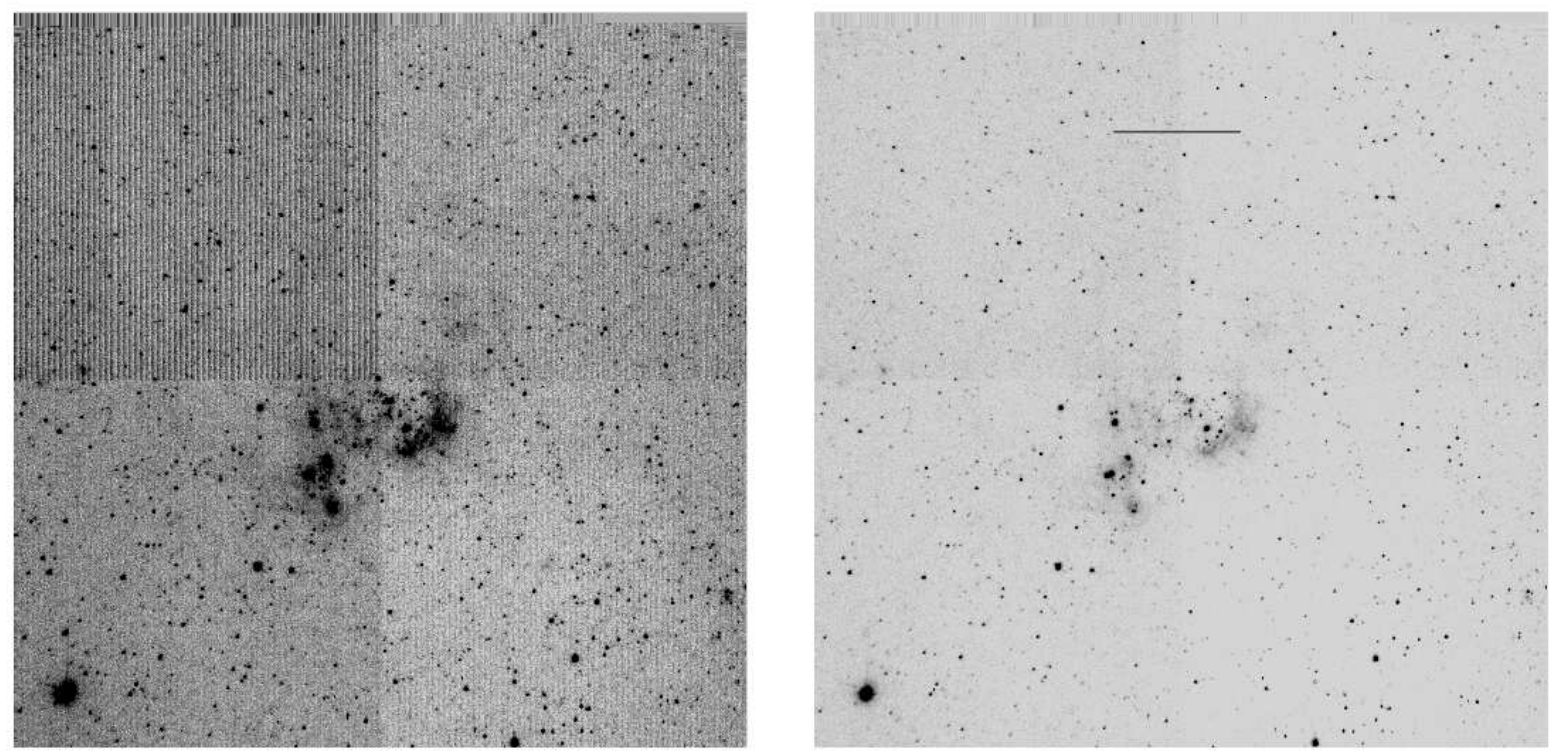

Figura 2.5: The left panel exhibits a Ks image after the flat-fielding correction but before the vertical striping correction was applied. The right panel exhibits the same image, divided by flat field and corrected by vertical striping using NIRINOISE routine. Both images are displayed exactly with the same scale to allow a faithful visual comparison.

Nevertheless, it is worth mentioning that this pattern will not affect the final photometry by three reasons:

1. The residual pattern does not produce a large difference in ADU from one quadrant to the other (the image gray scale was chosen to magnify the visualization of the effect). Figure 2.7 shows an horizontal cut along the image line that crosses the two upper quadrants in the right panel of Figure 2.5. The jump is clearly seen around $x$-axis pixel 95. Looking at the ADU levels, the middle value at the higher level side (left side) is $\sim 5555$ ADU and at the lower level side (right side) is $\sim 5525$ ADU, being the mean background value $\sim 5400 \mathrm{ADU}$ for the whole image. Hence, the jump represents the $\sim 0.5 \%$ of the background level (and the percentage is obviously much smaller for the emission objects).

2. The final image, in which the PSF photometry was performed, is the averaged image of several images at the same bandwidth. As this pattern is not present in all the images, the difference between the bias level at each quadrant in individual images is greatly diluted in the averaged final image.

3. Even in the case that this pattern survives in the final averaged image, as it is a large scale pattern, it has no consequences in the magnitudes of individual objects because it is included in the sky ring sample of each object. 


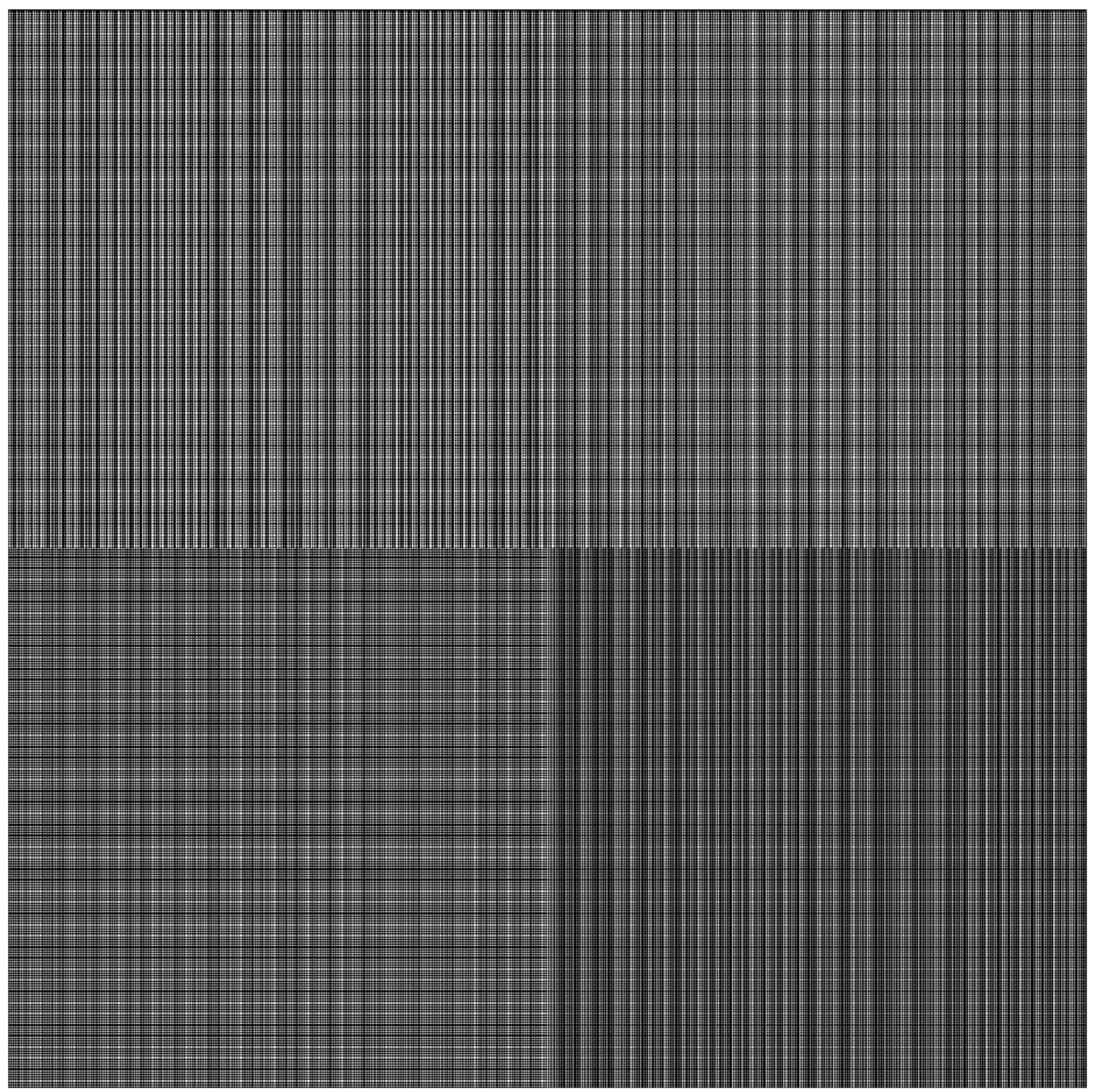

Figura 2.6: The vertical striping pattern derived by the task NIRINOISE.PY to correct the image in Figure 2.5. 


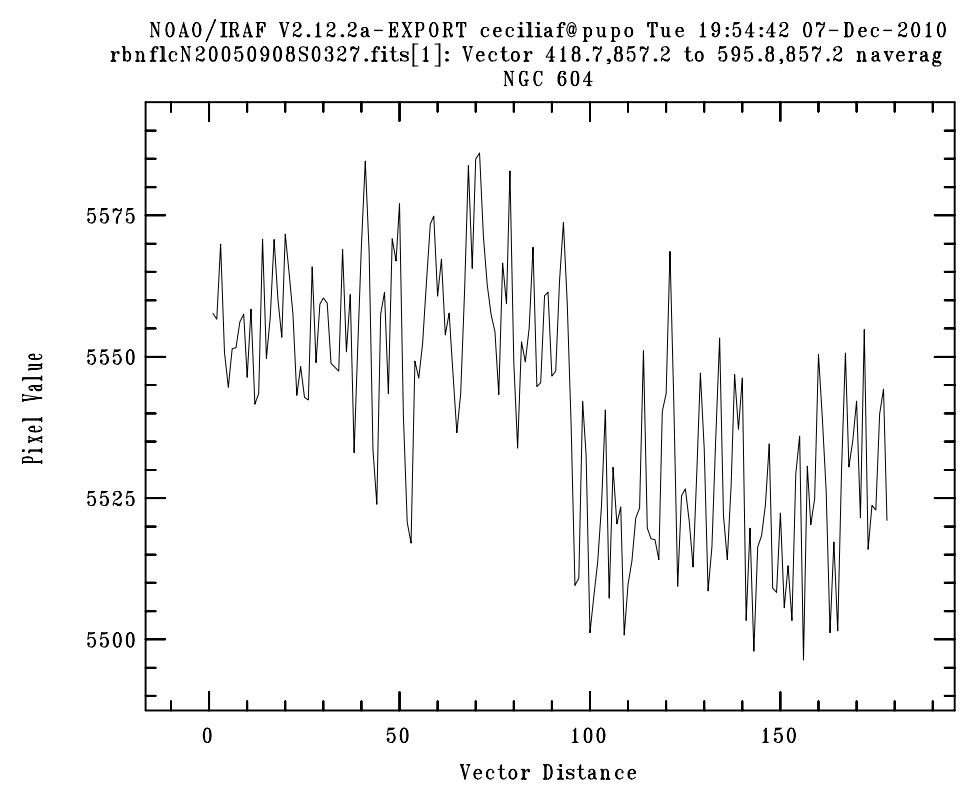

Figura 2.7: Counts statistics of the horizontal segment that crosses two quadrants in the image at the right panel of Figure 2.5.

\subsubsection{Non-linearity correction}

Next step after the vertical striping correction was to correct the images by the detector non-linear response. The task to perform this correction, NIRLIN.PY, is also a Python routine. The correction must be applied to all images with count rates greater than $\sim 20 \mathrm{ADU} \mathrm{s}^{-1}$. Figure 2.8 shows the count rates histograms for our images in all the bands. The histograms were obtained from an individual raw image of each filter divided by its exposure time. As can be seen, with the exception of $\mathrm{H}_{2}$ and $\mathrm{Pa} \beta$ images, for the other bandwidths the count rates are above $20 \mathrm{ADU} \mathrm{s}^{-1}$. Hence, the non-linearity correction was applied to all the $J, H, K s$, and $B r \gamma$ field and sky images, as well as to the photometric standards images. It was not applied to $\mathrm{Pa} \beta$ and $\mathrm{H}_{2}$, due to a warning at the NIRLIN.PY web page stating that data with count rates lower than $\sim 20 \mathrm{ADU} \mathrm{s}^{-1}$ should not use this routine because the coefficients were not properly calibrated. Recently, in October 2010, a beta version of the NIRLIN.PY routine, which works on all count rates, was released by Gemini-NIRI staff, but as its performance is not fully evaluated yet, it was not applied to our $\mathrm{Pa} \beta$ and $\mathrm{H}_{2}$ images. It is worth mentioning here that at low count rates, the images are supposed to be less affected by the detector non-linear response than at higher count rates. Nevertheless, the narrow-band images in this Thesis $(B r \gamma, P a \beta$, $\mathrm{H}_{2}$ ) were used only for a qualitative description of the ISM in the region (See Chapter 4) which conclusions will certainly not change when the $\mathrm{Pa} \beta$ and $\mathrm{H}_{2}$ can be corrected.

\footnotetext{
${ }^{6}$ NIRLIN.PY is provided by Gemini at http : //staff.gemini.edu/ astephens/niri/nirlin/.
} 


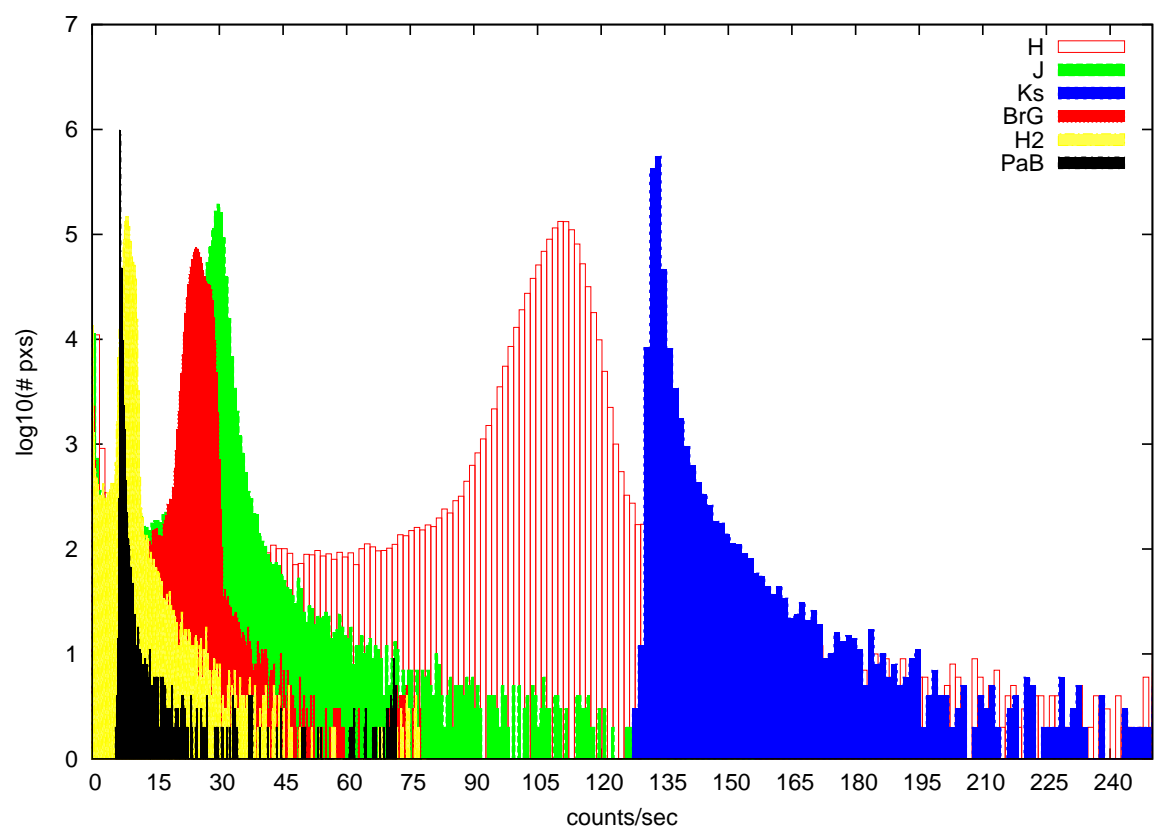

Figura 2.8: Count rates histograms for our images in all the bands. The histograms were obtained from an individual raw image of each filter divided by its exposure time. As can be seen, with the exception of $\mathrm{H}_{2}$ and $\mathrm{Pa} \beta$ images, for the remaining bandwidths the count rates are above 20 $A D U s^{-1}$.

The non-linearity correction for images with count rates grater than $20 \mathrm{ADU} \mathrm{s}^{-1}$ is expected to be reliable up to an upper limit of 12000 ADU per pixel. In Figure 2.9 ADU histograms are shown to compare the pixel values distribution before and after the non-linearity correction was applied. The panels sample two different sections of $101 \times 101$ pixels, from a raw $K s$ image. The sections' locations were chosen at the frame center (top panel) and at the top right corner of the frame (lower panel). From the filters set used for this Thesis, the $K s$ images exhibit the highest count rates $(>135.0)$ and the correction factor applied was $>1.0$ (see Figure 2.10). For both regions it can be observed that, as was expected, the counts increased after the linearity correction was applied (the image corrected histograms are shifted towards higher count values) and, although the histograms conserved the global shape, the corrected images present slightly flatter histograms, reflecting that the correction coefficient is not linear.

Figure 2.10 (taken from NIRI's web page) shows the non-linearity correction coefficients (blue dots and scale at the right side) that NIRLIN.PY routine applies to a constant brightness source, according to the exposure time and hence the count rate (scales at the bottom and left side respectively). The count rate is the green line fit (the residuals of this fit are shown at the bottom panel). Note that neither the correction factor behavior nor the count rates are linear functions of the exposure time, since the NIRI's detector response is a function of the counts in the pixel and the exposure time, but also the read out mode, the bias level, and the vertical 

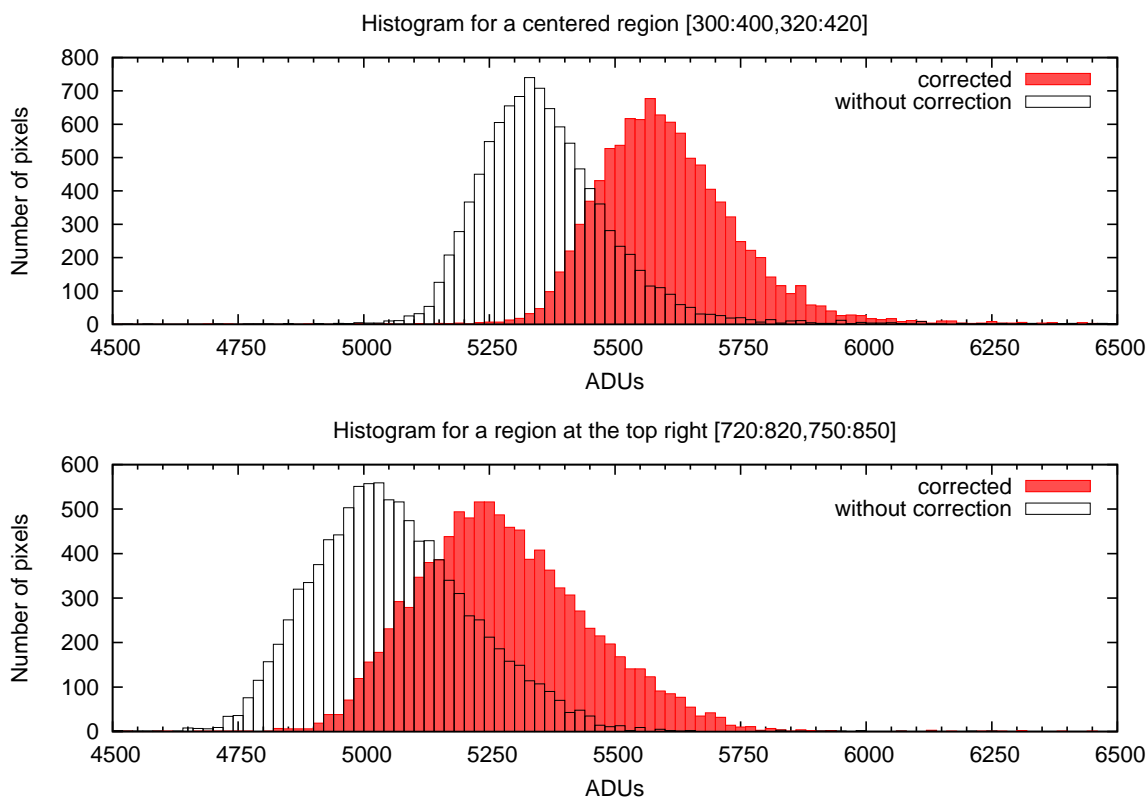

Figura 2.9: Histograms to compare the pixel values distribution before and after the linearity correction was applied. The panels sample two different sections of $101 \times 101$ pixels, from a raw Ks image. The locations where chosen at the frame center (top panel) and at the top right corner of the frame (lower panel).

position on the detector.

\subsection{Reduction process: IRAF tasks}

After the vertical striping and non-linearity image corrections, the reduction procedure follows using IRAF routines in the GEMINI.NIRI package. In the following items are listed, in sequential order, the IRAF routines used together with a brief summary of their function and the values for the routine's parameters used for our NIRI images. A plane description of GEMINI.NIRI routines can be found at http://www.gemini.edu/sciops/data/IRAFdoc/niriinfo.html, whereas a more complete routine description can be found at the IRAF help tasks' pages.

\section{- NPREPARE}

All images have to be run through the NPREPARE task before doing anything else. This task is basic, it adds and updates keywords on the image headers:

- $\mathrm{RDNOISE}=40.0 \rightarrow$ Is the readout noise, in $\mathrm{e}^{-}$.

For an individual image: readnoise $=(80,40$, or 11$) \times \operatorname{sqrt}\left(n_{-}\right.$coadds $)$. For our images the value used was 40.0 , corresponding to med readout noise. 


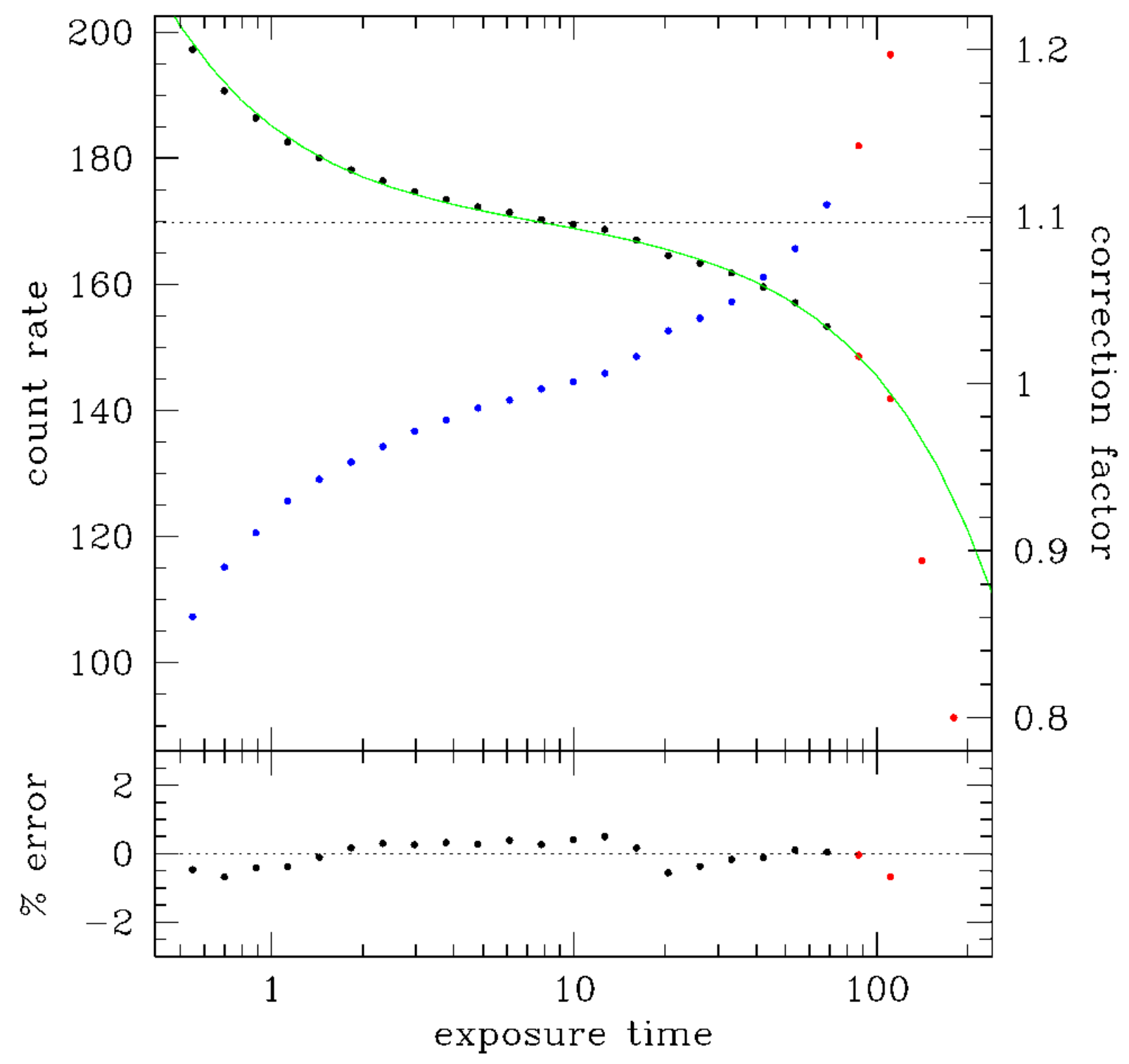

Figura 2.10: Figure taken from NIRI's web page which shows the non-linearity correction coeffcients (blue dots and scale at the right side) that NIRLIN.PY routine applies to a constant brightness source, according to the exposure time and hence the count rate (scales at the bottom and left side, respectively). The count rate is the green line fit (the residuals of this fit are shown at the bottom panel). 
- EXPTIME $=$ individual_exp_time $\rightarrow$ Is the exposure time, in seconds, for an individual image: exptime $=$ individual_exp_time $\times$ n_coadds.

- GAIN $=12.3 \rightarrow$ Is the number of electrons assigned per ADU for an individual image.

- SATURATI $=200000 \rightarrow$ Is the saturation value, in ADU, for an individual image: saturati $=[200,000$ or 280,000$] \times$ n_coadds, where 200000 corresponds to shallow well.

- NONLINEA $=140000 \rightarrow$ Is the limit for the linear regime, in ADU, for an individual image: nonlinear $=0.7 \times$ saturation value.

NPREPARE also creates the DQ and VAR planes.

\section{- NRESIDUAL}

When there is a (nearly) saturated object in one image, there is a persistence of residual images of the saturated object in the following images. NRESIDUAL takes the information on the DQ planes of previous images to flag as 'bad pixels' those pixels afected by the persistence of residual images, allowing to correct them in subsequent data reduction steps.

This task was run only on the standard and science broad-band images whereas it was not necessary to apply it in the sky and narrow-band images since the counts in those images are far below the saturation limit.

- NISKY

This task constructs the sky image. NISKY combines the sky images, after identifying and masking the objects.

- NIFLAT

This task constructs the flat field image and the bad pixel mask. The normalized flat field is created by combining the 'lamp on' images (acquired with the shutter open) and subtracting from it an image created by combining 'lamp off' images (acquired with the shutter close) to account for the thermal component of the flat field. The short dark images ( 2.0 seconds) were used to identify the bad pixels within the frame to create the bad pixel mask. The method used to combine the images was 'average'. All the important information regarding the NIFLAT's parameters used is stored in the resulting flat field image header.

\section{- NIREDUCE}

The science data must be run through NIREDUCE; this task operates algebraically with the science images using the sky image for the sky subtraction and the normalized flat field to divide the images. To restore the sky level to the original level and thereby maintain 
the noise characteristics of the image, the median of the sky level in the image is added on as a constant sky level. In Section 2.8 we will see that, may be at this point, something alters the images' statistics resulting in the understimation of the mean $\chi$ value of the PSF fitting.

NIREDUCE also updates the DQ and VAR planes for each image. The VAR frame contains the definitive measure of the noise in each pixel. The DQ frame is generated by combining the DQ frames of all the relevant input images, thus the resulting DQ frame contains all the flags that were present in the input images.

\section{- IMCOADD}

This task is used to generate the final image (in which the photometric analysis will be performed) by combining all the reduced science images. IMCOADD first derives the geometrical transformation between the images to register several dithered images of the same field (calling to GEOMAP and GEOTRAN tasks). Then, the task constructs the averaged image cleaning it for cosmic ray events (with the IMCOMBINE task). Each of the tasks called within IMCOADD has its own parameters' definitions. There are several forms in which this task can be used according to the chosen combination of parameters' definitions, and the output image turned out to be very sensitive to the selected options. In the following lines I summarize the best set of parameters, which I consider critical for this task, needed to obtain a good final image according to our image characteristics. These options were selected following what was written about IMCOADD at different documents but also after trying different options and examining the resulting images.

A very important point to start with is that IMCOADD operates over a list of science images to combine, taking the first image in the list as a reference for several important issues such as geometrical transformations and scale reference magnitudes. For this reason, the first image in the list must be the best available and the most representative of the image set. In the case of images taken with the dithering technique the final image will have the same field as the first image in the list.

The output images after running IMCOADD are listed below.

For each image in the IMCOADD input list the following files are generated:

- [image]_pos: a coordinate file with approximate objects' positions.

- [image]_cen: a coordinate file with objects' positions derived using APPHOT-CENTER with [image]_pos as the input file.

- [image]_trn: a position input file for GEOMAP. The entry in database will also be called [image]_trn. The file is made from [reference]_cen and [image]_cen which are files originated in the alignment procedure.

- [image]_trn_mag: is a file with photometric information used for scaling of the intensity of the images. 
- [image]badpix.pl: is the derived bad pixel mask for each image.

For the reference image (which is the first image in the list) the outputs are:

- [reference]_cen: a coordinate file for the reference image, with positions derived using APPHOT-CENTER with [reference]_pos as the input file, which is a file originated in the alignment procedure.

- [reference]_mag.tab: this file contains all the photometric information used for scaling the intensity of the images.

- [reference]_med.fits: is the derived median image.

- $[$ reference $]$ badpix.pl: is the derived bad pixel mask for the reference image.

- [reference]_avg.fits: is the uncleaned cosmic-ray average image. This image should not be used for photometry.

- [reference]_add.fits: is the cosmic-ray cleaned average image. This is the image that must be used for science photometry.

The file [reference]_add.fits is a MEF file with a complete header information on frame [0], but it has lost the VAR and DQ planes. Nevertheless, the information in the DQ is not lost since the $D Q$ planes of all the images were used to generate a bad pixel mask image for each input image.

Since we are dealing with images within a crowded field, with high variable background emission, the best option to perform the alignment of the images is doing it interactively with the 'alignmethod' option sets in 'user'. Thus, in the display window, two objects in common (the same objects) have to be marked manually in each image of the input image list. To do this the IMCOADD task is called twice:

1. The first time, the flags are set to:

$\mathrm{fl} \_$inter $+\mathrm{fl} \_$find $+\mathrm{fl} \_$map $+\mathrm{fl} \_t \mathrm{trn}-\mathrm{fl} \_$med $-\mathrm{fl} \_$add $-\mathrm{fl} \_$avg -

which means: interactively find the objects and derive the transformation between the images using GEOMAP, but still do not transform the images and do not derive the median, added, and averaged images.

2. The second time, the IMCOADD is called with the following flags:

$\mathrm{fl} \_$find $-\mathrm{fl} \_$map $-\mathrm{fl} \_$trn $+\mathrm{fl} \_$med $+\mathrm{fl} \_$add $+\mathrm{fl} \_$avg + which means: do not find the stars and do not derive the transformation (because is already done), but now do transform the images (with GEOTRAN) and derive the median, added, and averaged images.

The image [reference]_add.fits, from which we are going to derive the photometry, is on the same magnitude scale as the reference image (that is same same exposure time and airmass), hence it is really important that the first image in the IMCOADD input list had 
been acquired under photometric conditions, and as similar as possible as the conditions of the standard stars in order to obtain a good calibration photometric calibration.

The standard star images were reduced following basically the same procedure, the main difference is that for standard frames the sky frame was generated using the non-aligned standard frames. Also the IMCOADD task was run in a much simpler way.

\subsubsection{Comments on the image quality}

Before going on with the PSF photometry it is necessary to make some considerations related to the image quality.

Following the advice at NIRI's web pages, the first exposure from each dither sequence following a configuration or exposure time change was not included in the combination to generate the final image of each filter. As was previously explained, these images have a poor background noise subtraction and a large-scale phantom pattern (mainly produced by dark current) is evident. Nevertheless, we have found that this phantom pattern also appeared in each first image after making the offset from the sky frame position to the science frame position, being this effect particularly evident for images acquired with the $K s$ filter.

Figure 2.11 exhibits the complete $K s$-band image series. The images are already reduced (flat field divided and sky subtracted) and they are ordered (and numbered at the bottom left) following the sequence order in which they were acquired. All the images, except the last one labeled with 'final image', are displayed with the same intensity and color scales (linear gray scale with the limit at $99.5 \%$ of the pixel values distribution) to allow a faithful visual comparison among them. The legend on the left side of some images, 'SKY-X', indicates that before the image it precedes, a number $\mathrm{X}$ of sky images were acquired. Thus the $K s$-band series starts with a sky image which was discarded for being the first image of the series. The first field image, after the sky offset, is image number 1 and it also shows the large-scale pattern, and the same is repeated for images $7,11,13$, and 15 . A quick view of the sequence is enough to realize that all those images have in common (apart from the large-scale pattern) the fact that they are the first images after the telescope comes back from a sky offset pointing. But this does not happen to images 4 and 6 , which also are in the same condition. A detailed inspection of the observing logs, which have the original image names that include a number which is consecutive for consecutive images, revealed that two images were deleted and not delivered in the images set, these missing images are the one before image 4 and the one before image 6 , being those missing images the first images after the telescope comes back from a sky offset (and not 4 and 6). What probably had happened was that in these two images the pattern was so intense that, even without flat field correction and sky subtracted it was evident. Gemini staff detected the 

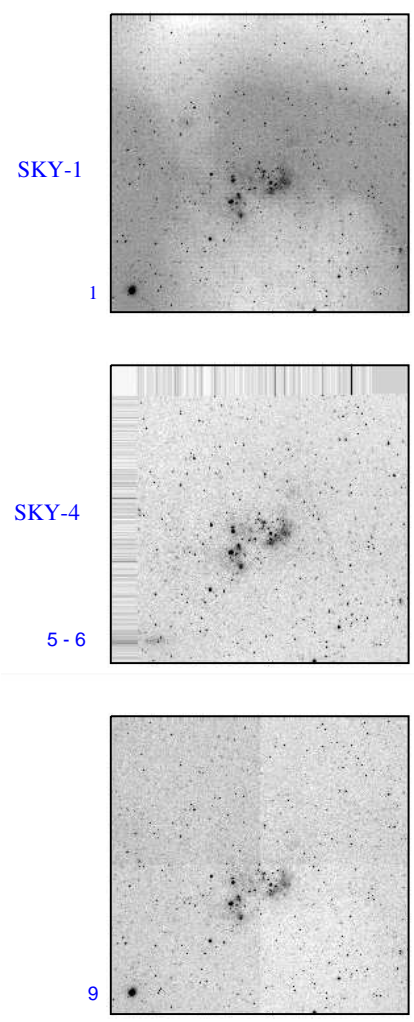

12
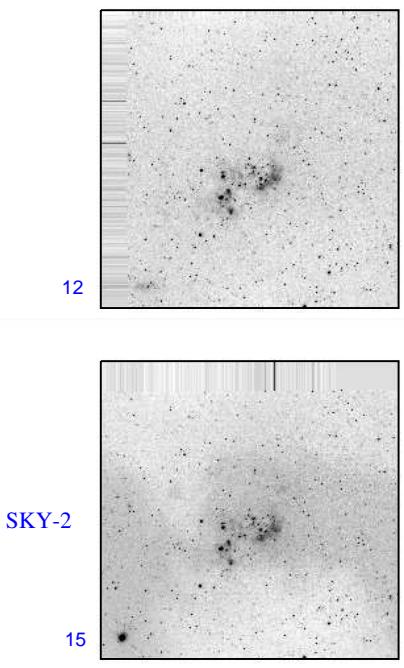
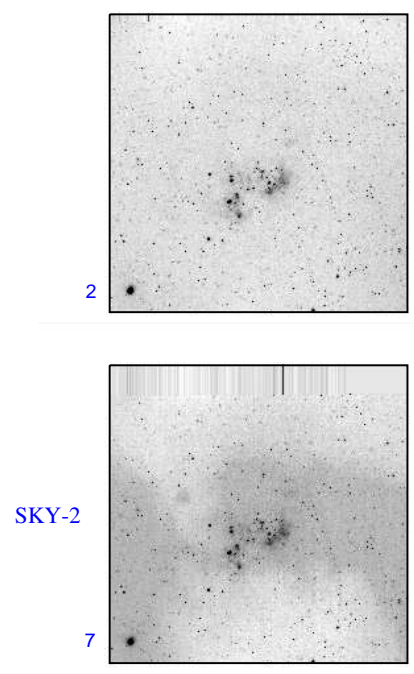

10
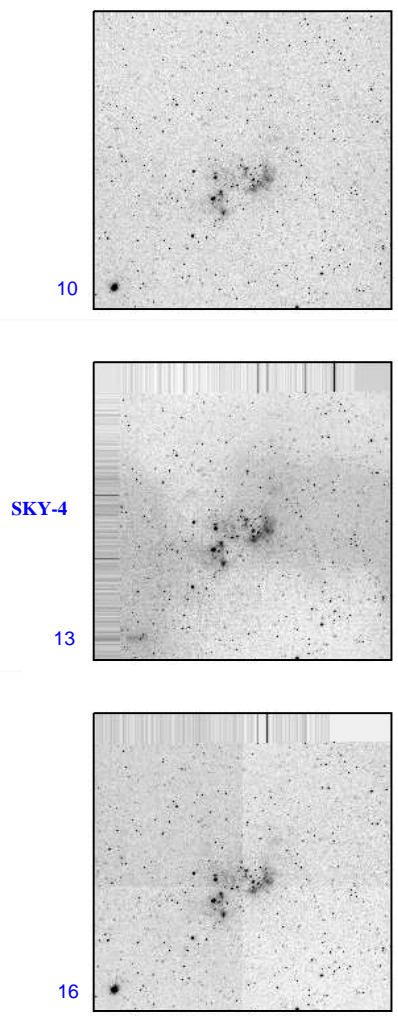
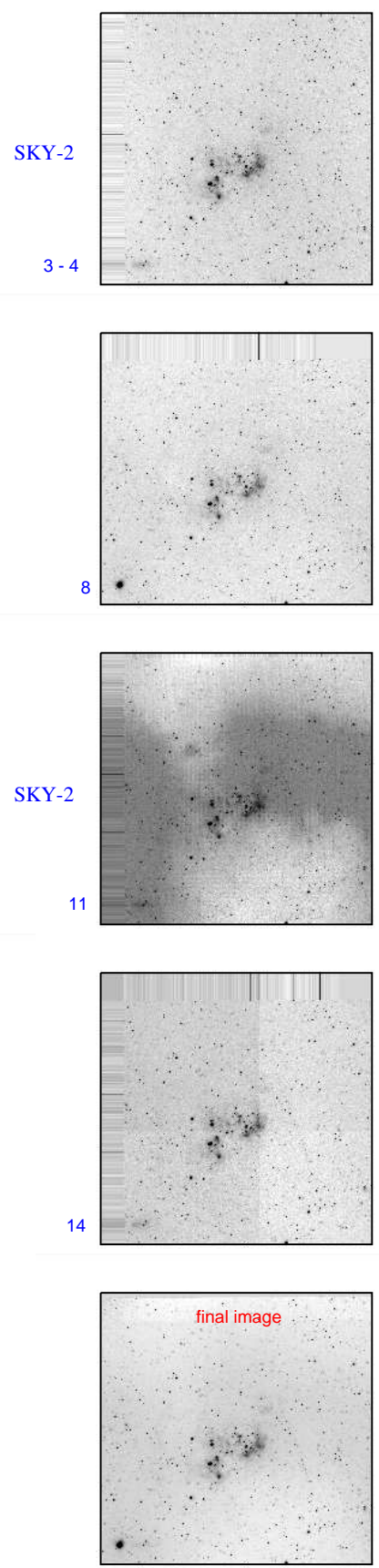

Figura 2.11: Complete Ks-band image series; the images are reduced (flat field divided and sky subtracted). The panels are ordered (see the number at the bottom left) following the sequence order in which the images were acquired. All the images, except the last one ('final image'), are displayed with the same intensity and color scales to allow a faithful visual comparison among them. The legend on the left side of some images, 'SKY-X', indicates that before the image it precedes, a number $X$ of sky images were acquired. 
problem during their quality assessment and decided not to include them among the delivered images. Another thing worth noting is that the pattern is not present in the first sky frames after the offset from the field to the sky.

Note that the dithering sequence is easy to follow in Figure 2.11 since, due to the alignment process, the images with displacements with respect to the reference image exhibit a spurious line pattern on some of their borders.

In Figure 2.11 it is also evident that in many images the four quadrants exhibit different bias levels. As was explained, this pattern disappears in the last image labeled with 'final image' (which is the image generated by combining all the previous field images), contrary to the phantom pattern, still present in the 'final image'.

Regarding the large-scale pattern, it is worth considering two issues at this point: the first is that being a large-scale pattern, its net effect over the magnitudes of individual objects is expected not to be utmost important because it is also included in the sky ring sample during the PSF fitting process. The other point to consider is that discarding all the images with the pattern, means to loose half of the total number of field frame images for the $K s$-band, leading to a noisier and shallower photometry.

However, nobody likes to include this kind of images in the photometry unless is sure about its effect. Hence, to evaluate this, two combined images were generated: one with all the images (including the ones with phantom pattern) and the other with only the 'clean' images. The results are shown in Figure 2.12, where the left panel exhibits the image generated with all the $K s$ frames and the right panel shows the image generated including only the frames without the phantom pattern. Again, the images are displayed with the same scale to allow a faithful visual comparison among them. The red vertical line is highlighting the column from which the line profile in Figure 2.13 was generated in order to graphically show the effect of the large-scale pattern. The chosen column crosses a region of the images clearly affected by the pattern, and as it is evident the lower curved profile in Figure 2.13 belongs to the $K s_{-}$all image. Table 2.5 summarizes the results of a basic statistics over the whole image area considered for the photometry (from pixel 100 to 1006 in the image $x$-axis and 25 to 916 in the $y$-axis) for the images shown in Figure 2.12. The difference in ADU, as a whole, is of $\sim 25$ over a mean value of $\sim 5455$ (that is $\sim 0.4 \%$ ).

PSF photometry was performed independently on both $K s_{-}$all and $K s_{-}$clean images, computing the PSF model for each image individually. The magnitudes derived from the PSF fitting in both images were compared object to object, and the results are shown in Figure 2.14. The top panel is a plot of the one to one correlation between the object's magnitudes derived from both images. The correlation exhibits, as was expected, a little scatter towards higher magnitude values. The middle panel shows the difference between the ks_all magnitudes and the ks_clean magnitudes versus the magnitude, in this plot is clear that the differences in the magnitudes derived from both images are within the mean error value of the difference

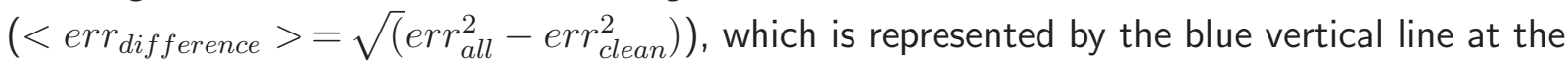




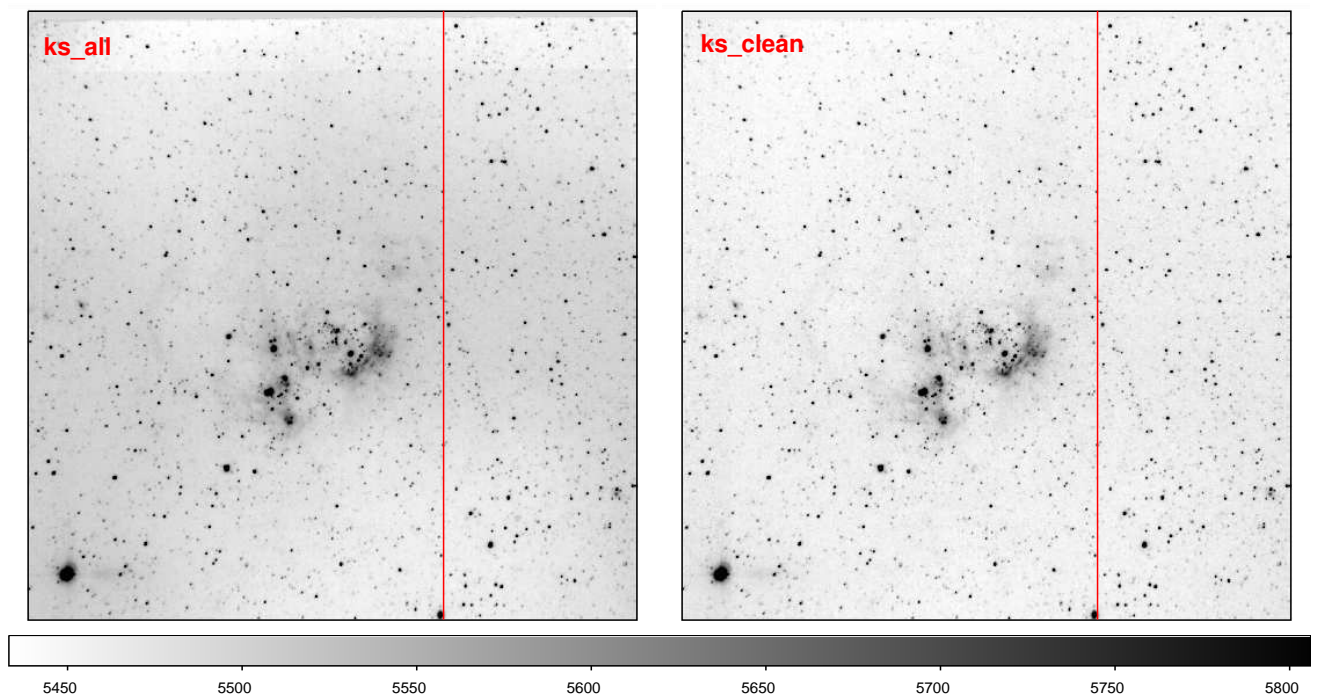

Figura 2.12: Left panel: combined image generated with all the images (including the ones with the large-scale pattern). Right panel: combined image generated only with the 'clean' images. Note that the image in the left panel is the same as the last image in Figure 2.11. The images are displayed with the same intensity and color scales to allow a faithful visual comparison among them. The red vertical line indicates the column from which the line profile in Figure 2.13 was generated.

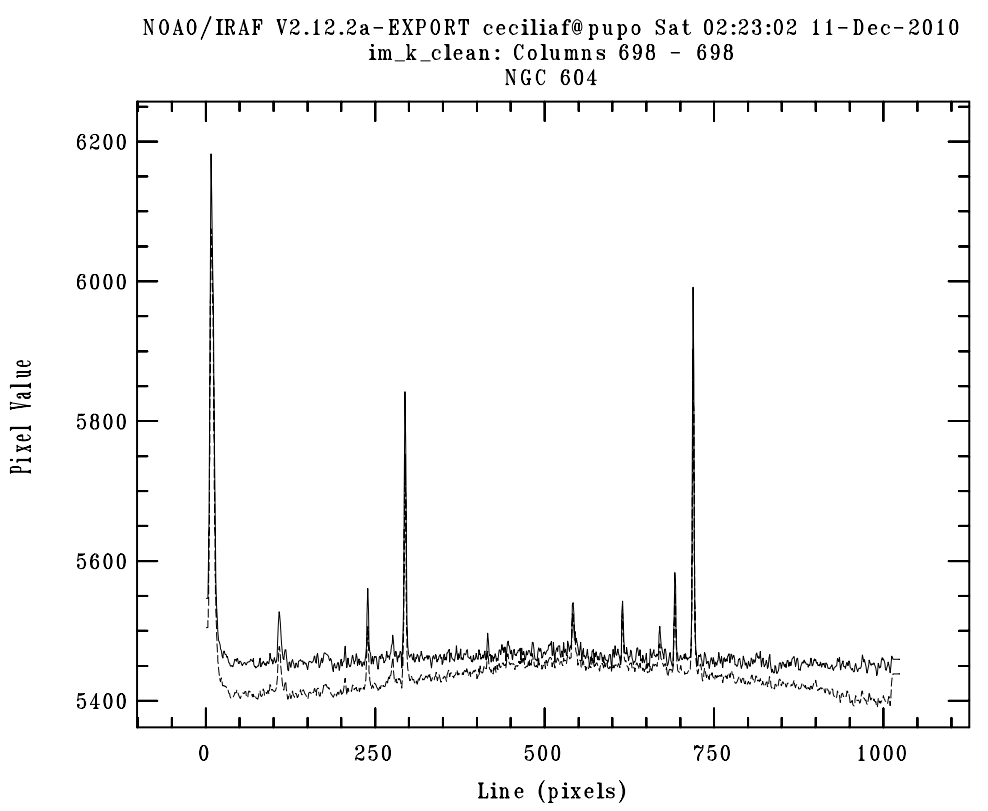

Figura 2.13: Line profiles corresponding to the same column in both images of Figure 2.12. The chosen column crosses a region of the images that is affected by the large-scale pattern. As it is evident, the lower curved profile belongs to the Ks_all image. 


\begin{tabular}{ccccccc}
\hline Image & N. Pix & Mean & Mode & Std. Dev. & Min. & Max. \\
\hline im_k_all[100:1006,25:916] & 809044 & 5445. & 5447. & 84.72 & 5393. & 17978. \\
im_k_clean[100:1006,25:916] & 809044 & 5469. & 5459. & 93.81 & 5417. & 19124. \\
\hline
\end{tabular}

Table 2.5: Results of a basic statistics over the whole image area considered for the photometry (from pixel 100 to 1006 in the image $x$-axis and 25 to 916 in the y-axis) for the images shown in Figure 2.12.

left side of the plot. Finally, the bottom panel, shows the difference between the magnitude's uncertainties from the ks_all magnitudes and the ks_clean magnitudes versus magnitude, where it can be observed a slight trend to take values below zero, meaning that the uncertainties of the ks_all magnitudes are, in general, lower than the uncertainties of the $K s_{-}$clean magnitudes.

The last item regarding the image quality is that there were also four science images that were not included to construct the final averaged images because they exhibit evident features of 'movement' (as surprising as it sounds!). These images are shown in Figure 2.15, where it can be observed the features produced by the 'movement': stars with high elliptical shapes, bright stars trails, 'double stars' images, etc.

\subsection{The astrometry}

Once the final averaged images for each filter were ready to perform the PSF photometry, a spatial transformation among all the images (including the narrow-band filter images) was performed to register them to the same 'image coordinate system'; in this way the objects have the same coordinates in all the images and it is possible to work with a unique objects' coordinates list.

The task used to compute the spatial transformation functions was GEOMAP. This task needs an input list with the $(x, y)$ physical coordinates of selected points in common in the reference and input images. These points were selected as the physical coordinates of point sources' centers obtained by performing a quick aperture photometry with the IMEXAMINE task. In the GEOMAP task it is important to define the parameters xmin, xmax, ymin, and ymax with the values of the physical coordinates of the image corners, otherwise the task trims the images at the position of the most extreme coordinates in the input list of the reference frame. The computed transformations were then used by the GEOTRAN task to transform the images to a common 'image system'.

The following step is the transformation from $(\mathrm{x}, \mathrm{y})$ image coordinates to $(\alpha, \delta)$ celestial equatorial coordinates. To do this, the tasks CCMAP and CCSETWCS were used. These tasks 

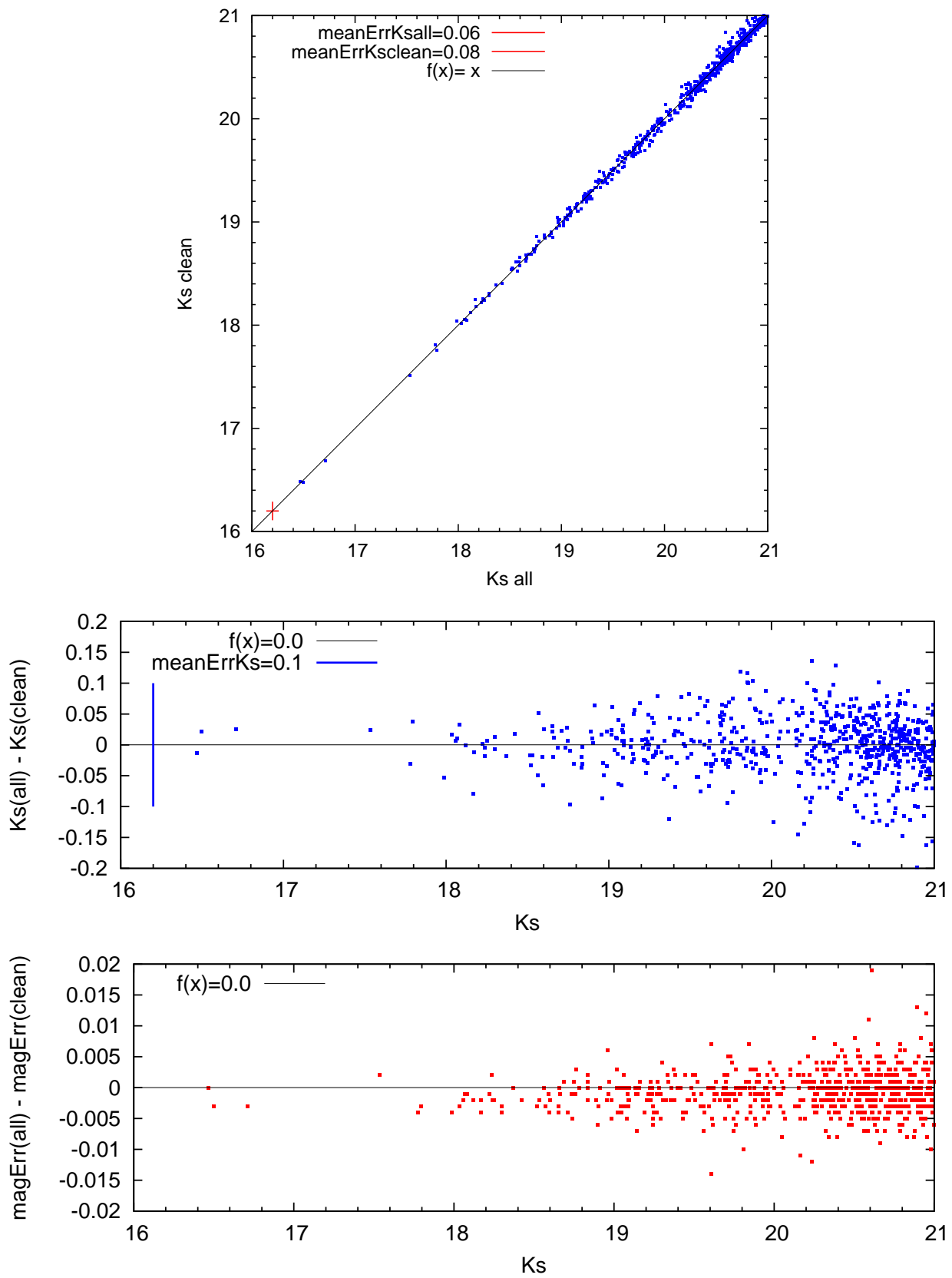

Figura 2.14: The top panel shows the one to one correlation between the object's magnitudes derived from ks_all and $k s_{-} c l e a n$ images. The correlation exhibits an increasing scatter towards higher magnitude values. The middle panel shows the difference between magnitudes derived from the ks_all and the ks_clean images versus the magnitude. The differences in the magnitudes derived from both images are within the mean error value of the difference, which is represented by the blue vertical line at the left side of the plot. Finally, the bottom panel shows the difference between the magnitude's uncertainties of ks_all magnitudes and ks_clean magnitudes versus the magnitude, where it can be observed a slight trend to take values below zero, meaning that the uncertainties of the ks_all magnitudes are, in general, lower than the uncertainties of Ks_clean magnitudes. 

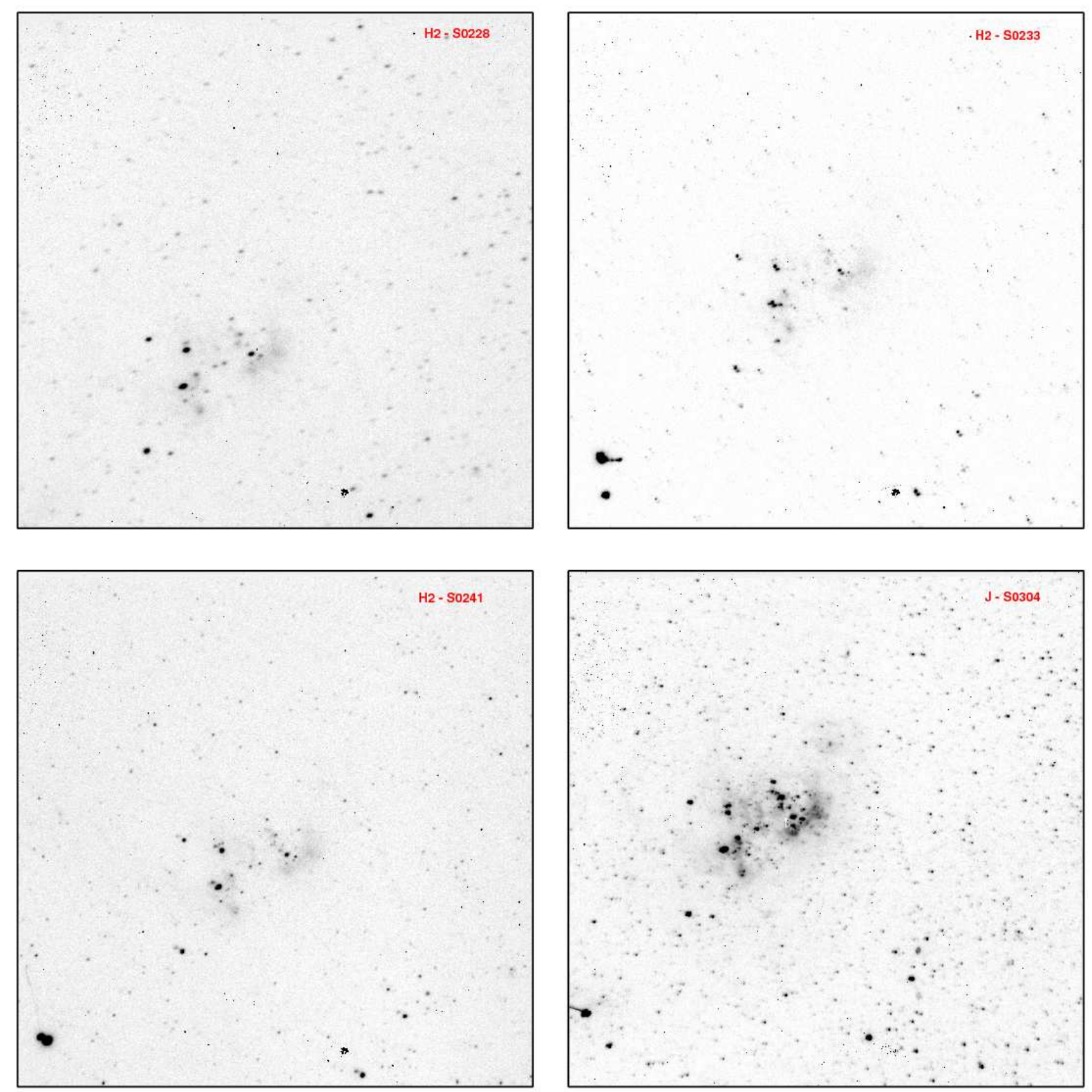

Figura 2.15: Images where the features produced by the 'movement' are evident: stars with high elliptical shapes, bright stars trails, 'double stars' images, etc. These images were not included to construct the final averaged images. 
work with a similar procedure as GEOMAP and GEOTRAN. CCMAP computes plate solutions using image $(\mathrm{x}, \mathrm{y})$ reference coordinates and $(\alpha, \delta)$ celestial coordinates of an input objects list. Then, CCSETWCS creates the image world coordinate system (WCS) using the computed plate solution. The stars in the input list required by CCMAP, for which we must know the celestial coordinates, were selected from the objects in common between our images and the Guide Star Catalog (GSC) for HST target coordinates at version 2.3.2 ${ }^{7}$. The reference frame of this catalog is the International Celestial Reference Frame (ICRF) and Equinox J2000. The GSC 2.3.2 typical errors are $\sim 0.3$ arcsec. The transformation $\mathrm{RMS}^{8}$ are 0.35 and 0.25 arcsec for right ascension and declination, respectively. The Figure 2.16 exhibits the 55 GSC's point sources used to perform the plate solution. In this figure it can also be observed that the selected stars are well spanned all over the field.

\subsection{Point spread function photometry}

This Section is dedicated to describe the procedure followed to perform the PSF photometry to obtain the objects' magnitudes from the broad-band JHKs images.

The PSF photometry was performed with the DIGIPHOT - DAOPHOT, IRAF package. The DAOPHOT software package was developed by Stetson (1987) specially to perform stellar photometry in crowed fields. The PSF fitting was basically done following the procedures and advices at 'A Reference Guide to the IRAF/DAOPHOT Package' by Davis (1994) and 'A User's Guide to Stellar CCD Photometry with IRAF' by Massey \& Davis (1992) as well as the DIGIPHOT DAOPHOT and IRAF help pages and the original publication.

The first essential thing to do, before starting with the PSF fitting, is to check that all the images' headers contain the information (the keywords and their correct values) that the different DAOPHOT's tasks will require during the PSF fitting. Although time consuming, this prevents future mistakes in the photometry, because sometimes the IRAF routines do not send any warning message if a parameter is not found, instead the tasks directly use the default parameter value, which may not be appropriate for the images of interest. Hence, the images' headers were updated and completed with the adequate values for the keywords that define the instrumental characteristics - FILTER (for the image filter), SATURATI (for saturation value), and NONLINEA (for upper limit at the detector linear regime), RDNOISE (for the readout noise), and GAIN (for the the number of $\mathrm{e}^{-}$assigned per ADU) - and the observational characteristics - EXPTIME (for total exposure time), AIRMASS (for air mass). Part of this information was lost during the astrometric transformation procedure, when the general image

\footnotetext{
${ }^{7}$ http: //gsss.stsci.edu/Catalogs/GSC/GSC2/GSCIIProperties.html

${ }^{8}$ RMS: root mean square.
} 


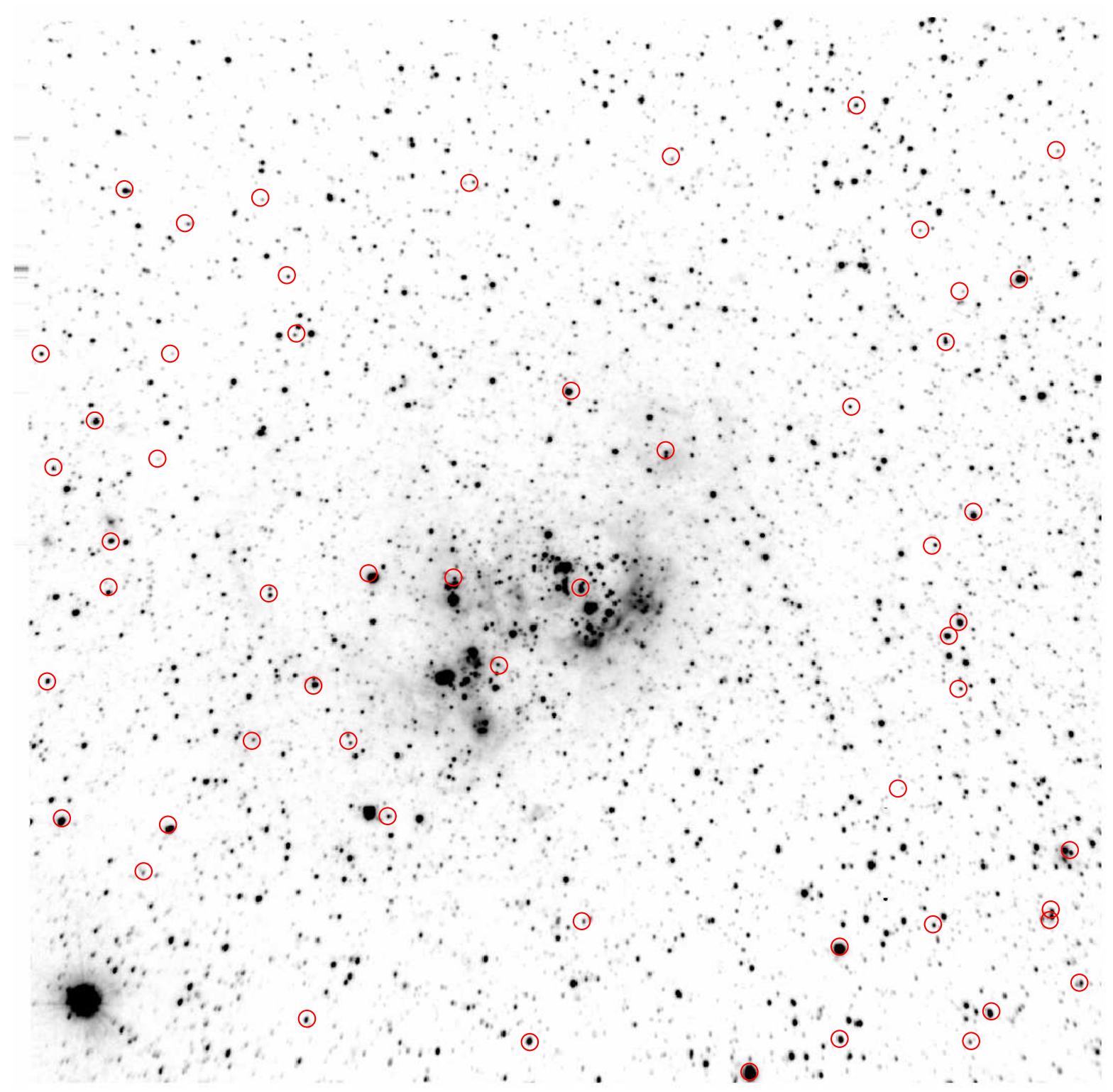

Figura 2.16: This figure shows the field distribution of the 55 GSC's point sources used to perform the plate solution to transform the $(x, y)$ image coordinate system to the $(\alpha, \delta)$ celestial coordinate system. As can be seen the selected stars are well spanned all over the field. 


\begin{tabular}{cccccc}
\hline $\begin{array}{c}\text { Filter } \\
(1)\end{array}$ & $\begin{array}{c}\text { airmass } \\
(2)\end{array}$ & $\begin{array}{c}\text { rdnoise } \\
(3)\end{array}$ & $\begin{array}{c}\text { gain } \\
(4)\end{array}$ & $\begin{array}{c}\text { nonlinea } \\
(5)\end{array}$ & $\begin{array}{c}\text { saturati } \\
(6)\end{array}$ \\
\hline $\mathrm{J}$ & 1.026 & 154.1 & 172.2 & 11342 & 16220 \\
$\mathrm{H}$ & 1.048 & 164.8 & 196.8 & 11493 & 16371 \\
$K s$ & 1.043 & 154.1 & 172.2 & 11313 & 16191 \\
\hline
\end{tabular}

Table 2.6: Main image header values required by the DAOРнот's tasks.

header plane, plane [0] of the MEF image file, was missed. In Table 2.6 the values of these keywords are listed for each broad-band image.

Another important quantity that should be well determined is the mean FWHM for each image, which determined by a combination of instrumental characteristics and atmospheric conditions.

Following with the description of basic quantities for performing photometry, most of the DAOPHOT tasks used in this process call to the datapars parameters file. This file contains information about all the data dependent parameters which are fixed for each image. This information is mostly included in the image header (the keyword values mentioned before). The few parameters which are not included in the image header are:

- datapars.scale $=1.0 \rightarrow$ Is the image scale in user units per pixel (as for example arcsec per pixel). Many other parameters used when doing photometry are defined 'in units of the datapars scale parameter'. Setting the scale units in 1.0 means that we are working in pixels units, which is the best option for us.

- datapars.fwhmpsf $=3.0 \rightarrow$ Stores the value of the full-width half-maximum of the point spread function in scale units. This value was derived, for each image, by performing circular aperture photometry interactively with the IMEXAMINE task at the position of several objects well spanned along the image (the $J, H$, and $K s$ images have the same FWHM value).

- datapars.sigma $=[\mathrm{var}]^{9} \rightarrow$ Is the standard deviation of the sky pixels; this value should be set to a value representative of the noise in the sky background. The sigma value for each image was derived from the image's statistics, at different locations in the image, also with IMEXAMINE task. The derived value was corroborated with the value obtained

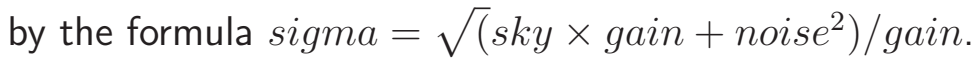

- datapars.datamin $=[\mathrm{var}] \rightarrow$ Minimum good data value in ADU. Each image has a different value which can be set as the mean sky value minus a factor times the sigma value $\left(\right.$ datamin $=$ mean $\left._{s k y}-A \times \sigma_{s k y}\right)$.

\footnotetext{
${ }^{9}[\mathrm{var}]$ is written here to indicate that this value varies for the JHKs images.
} 
- datapars.datamax $=12000 \rightarrow$ Maximum good data value in ADU. The upper limit for the counts of a pixel to be used for fitting the PSF was set to 12000 ADU, as this is the highest value for which the linearity correction is expected to be reliable.

Hence three parameter files (one for each broad-band image) were generated once, with the image header keywords and the appropriate values for the quantities described above. These files were then loaded whenever was required by DOAPHOT tasks.

The procedure to perform PSF photometry can be schematically described as follows:

1. Generate an objects list.

2. Perform aperture photometry to the objects in the list to be used as a reference value.

3. Select a list of 'PSF' stars to generate the PSF model.

4. Generate the PSF model iteratively.

5. Apply the PSF model to all the stars in the list and subtract the fitted stars. Examine the subtracted image and if new stars are detected (probably hidden by bright stars that outshine them) include them in the objects list and, again, apply the PSF model to all the stars (new ones included). This step must be repeated until the final subtracted image is 'clean' from stars.

Although short to enumerate, each of these stages in the process of PSF fitting has subtleties. The next paragraphs are devoted to explain with some detail how each of these steps was performed.

\section{Generate an objects list}

To find the stars and generate the list with their $x-y$ positions the task DAOFIND was run over an image created by adding the $J$ and the $K s$ images. The $J$ and the $K s$ images were chosen because they are in the extremes of the wavelength range covered by the observations. The idea behind this, is that the $J+K s$ image well samples both, the stars that are bluer (with high emission at the $J$-band) and also the objects that, for any reason, are red shifted (which will present high emission in the $K s$-band). There is also another advantage regarding to this election: a unique objects coordinates list (instead of having three different, one for each filter) is going to be generated and used in the PSF fitting process. As will be explain in the following paragraphs working with a unique coordinates list simplifies the matching process. It is evident that using this 'fixed' objects list will prevent us to make a completness analysis in the standard way; nevertheless, as this study is not intending to derived mass/luminosity functions this limitation does not undermine our goal. 
The DAOFIND main parameters are the datapars.fwhmpsf and datapars.sigma (previously explained) and findpars.threshold. The latter is the object detection threshold above local background in units of datapars.sigma. These three parameters basically define what is going to be considered as an object to perform the photometry. The task will search in the image for local density maxima, with a FWHM equal to the datapars.fwhmpsf value, and a peak amplitude greater than findpars.threshold $\times$ datapars.sigma above the local background. Together with the $x$-y coordinates DAOFIND also calculates a 'raw' magnitude ( $\mathrm{mag}=-2.5 \times \log 10$ (peak density/detection threshold)) and computes three shape parameters: the sharpness and two estimates of roundness.

To define the best findpars.threshold value DAOFIND was run with findpars.threshold= 3.0, 4.0, and 5.0. A careful examination of each output objects list (by marking the founded objects in the image) indicated that the best choice of the findpars.threshold value, for the goals of this study, was 5.0, since the detected objects list seemed quite complete and did not include spurious or 'doubtful' very weak objects. Thus, setting the values:

- datapars.fwhmpsf $=3.0$

- datapars.sigma $=7.0$

- findpars.threshold $=5.0$

yielded a final coordinates list that includes a total of 4729 objects.

\section{Perform aperture photometry for reference magnitudes}

It is necessary to perform a first basic aperture photometry for all the objects in the list, since the magnitudes and the sky values derived here are going to be used as reference values for the PSF fitting. Aperture photometry at this stage in done with the PHOT task. The important parameters to be defined (apart form the ones in the datapars parameters file) are at the centerpars, fitskypars, and photpars parameters files. These three files set the values for the centering, sky fitting, and the parameters for the photometry, respectively. The main parameters at these files are ${ }^{10}$ :

- centerpars.calgori $=$ "none" $\rightarrow$ Defines the centering algorithm (is set in "none" since the objects were well centered by the DAOFIND task).

- fitskypars.salgori $=$ "centroid" $\rightarrow$ Defines the sky fitting algorithm. The "centroid" algorithm computes the weighted intensity mean of the sky pixel histogram, being reasonably robust for crowded regions or regions with rapidly varying sky background.

- fitskypars.annulus $=10.0 \rightarrow$ Defines the inner radius of the annular sky fitting region (in pixels).

\footnotetext{
${ }^{10}$ These main parameters take the same values for the three filters.
} 
- fitskypars.dannulus $=10.0 \rightarrow$ Defines the width of the annular sky fitting region (in pixels).

- photpars.apertur $=3.0 \rightarrow$ Defines the aperture radii (in pixels) for the photometry.

\section{Select a list of 'PSF stars' to generate the PSF model}

At this stage is when the process to construct the PSF starts. 'The PSF is the two dimensional brightness distribution produced in the detector by the image of an unresolved source, such as a star' (Stetson, 1987). The PSF model is constructed using a set of selected stars as template. This model is applied to the rest of the stars under the DAOPHOT fundamental assumption which states that the PSF is constant or varies smoothly with position over the image and all the stars in the image must be indistinguishable except for position and magnitude. Thus, the final instrumental magnitude of an object is given by the scale factor of the PSF model that produces the best fit in the object image. It is worth nothing here that, as we shall see, it is possible to compute a variable PSF capable of handling second order variability as a function of position in the image.

The PSF model is determined from the actual observed brightness values as a function of $x$ and $y$ for the PSF selected stars. The PSF model has two components, the first component is an analytic function which approximates the light distribution in the cores of the PSF stars. The parameters of the analytic function are computed by fitting all the PSF stars weighted by their S/N. The second component stores as 'look-up tables' the deviations (fit residuals, first and second order derivatives of the PSF in $x$ and $y$ image coordinates) of the 'true' PSF from the computed analytic PSF model. The look-up tables are used as additive corrections from the integrated analytic function to the actual observed empirical PSF. The number of look-up tables is set by the the order of variability of the computed PSF model. For computing PSF model in this Thesis, the highest variability order available was used; this model allows the PSF fitting process to account for smooth linear and quadratic changes in the PSF across the frame, caused by low order optical aberrations, etc.

When the empirical PSF model is constructed the selected PSF stars need to be the 'best' stars in the image, that is, they need to be bright stars (but, as much as possible, their intensity must be in the linearity range of the detector), isolated sources (no other star lies within the $\sim 2$ fitting radius), and no bad pixels must be near. Also, it is advisable to examine the radial profile of the selected objects to confirm it has 'normal' star shape (according to our images characteristics). The PSF model constructed for these Gemini-NIRI images is variable (up to a second order) with the object $x$-y position in the 
frame, so it was fundamental to select PSF stars well distributed all over the image field, since an object shape sample of every place in the frame was needed. The order of the variable PSF also determines the minimum number of PSF stars to be used to generate the PSF model. According to the PSF task's help pages around 25-30 PSF stars was a reasonable number, but the more crowded the field the more PSF stars are required to lower the noise generated by neighbor subtraction.

Finding 25-30 good PSF stars spanned the whole image area sounds easy considering that the PHOT list contains 4729 objects but, unfortunately, this idea is far from the actual situation. Many stars that look fine at first sight turned to reveal a hidden neighbor star, had a strange shape profile, lied beyond the linearity limit, etc. Therefore, the PSTSELECT task was used to generate a first list of PSF stars, which contained 200 PSF star candidates. After a careful examination of each of these stars (using IMEXAMINE) a second selection of 80 PSF star candidates was made. The last step in the PSF stars' selection took place by using the latter list as the input psffile (i.e. the input PSF star photometry file) for the first run of the PSF task. The PSF task was run several times in the interactive mode, and a few stars from the original psffile were deleted in this process. The final PSF stars list for each broad-band filter had around 70 stars. The PSF stars used in the three filters were nearly the same stars with the exception of a few objects that exhibited special features in some of the filters. Figure 2.17 shows the spatial distribution of the stars at the final PSF star list for the $J$ filter. Note that the stars are homogeneously distributed in the frame with the exception of the the central region, which was avoided because it is a crowded area with highly variable background emission. There were no stars selected close to the image's borders because the $\mathrm{S} / \mathrm{N}$ drops in those areas since by the dithering sequence, the image's edges of the combined image are less exposed, thus the effective photometry area was limited to the area in common for all the dithered images).

Another important thing is to choose an appropriate first star for the PSF stars list, since the instrumental magnitude scale is set by the magnitude assigned to the PSF model, which is the magnitude of the first PSF star in the photometry file. The first PSF star in our list was chosen to have a magnitude $\sim 20.0$ in each filter, which is approximately the peak of the stars magnitudes distribution.

\section{Generate the PSF model iteratively}

The PSF construction involves an iterative and interactive run of PSF, NSTAR, and SUBSTAR tasks from the DAOPHOT package. Since we want to generate a variable PSF (of order 2), it is necessary to run a sequence of these tasks three times: a first iteration to construct a constant PSF, increasing steeply its order in the following iterations. In this 


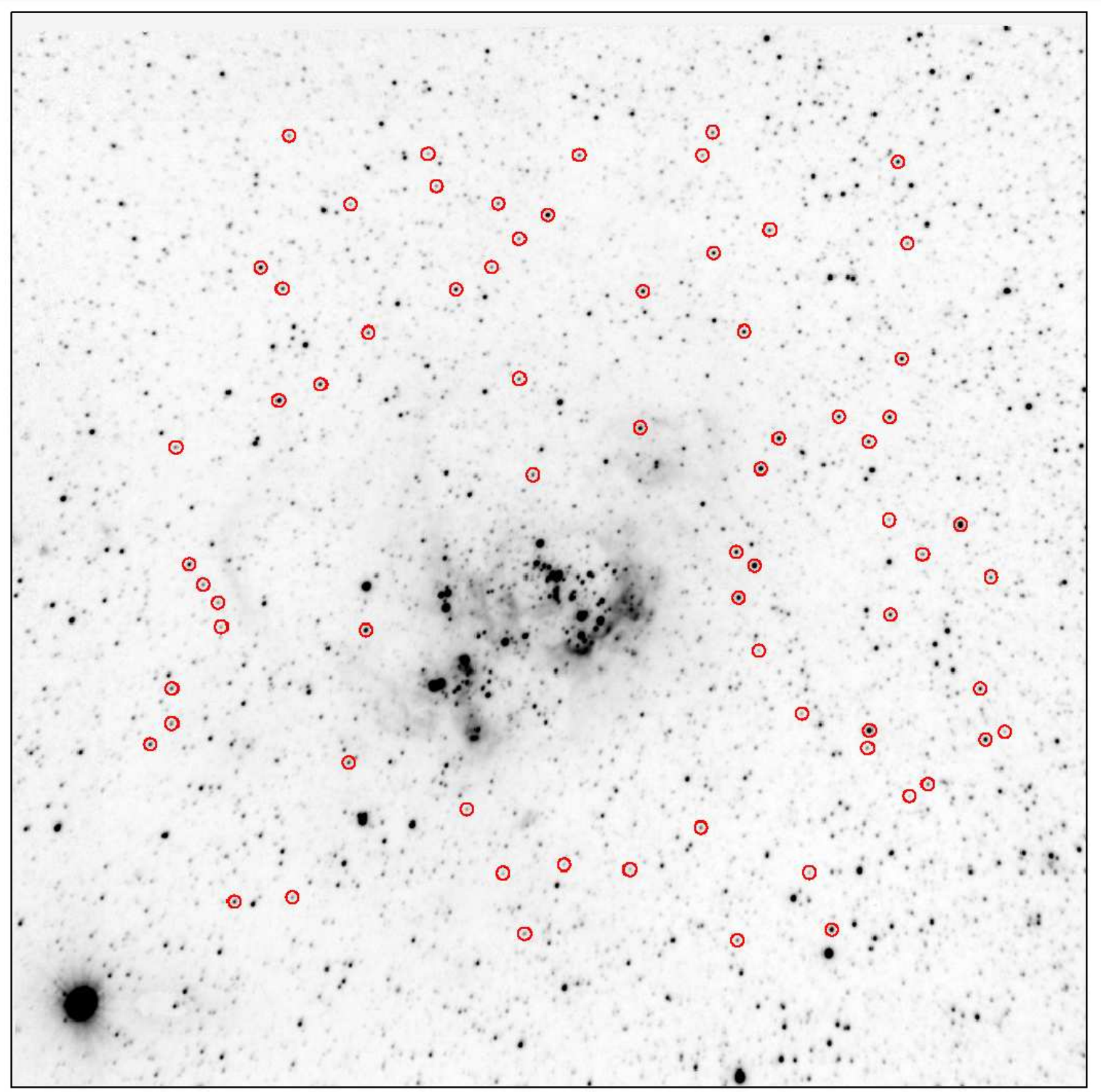

Figura 2.17: Spatial object distribution for the final PSF star list for the J filter. Note that the stars are homogeneously distributed in the frame with the exception of the the central region which was avoided because it is a crowded area with highly variable background emission. There were no stars selected close to the image's borders because the $S / N$ drops in those areas since by the dithering sequence, the image's edges of the combined image are less exposed. 
way, we avoid mistaking neighbor stars for variations in the PSF.

The scheme followed was:

a) Run PSF interactively to obtain a constant PSF model (with varorder $=-1$, no lookup tables are generated at this step).

b) Run NSTAR and SUBSTAR tasks and carefully examine the results. If everything is fine generate a new image in which all the PSF stars' neighbors are subtracted but the PSF stars are present.

c) Run PSF over the neighbor subtracted image with a higher order (with varoder $=0$, one look-up table containing the fit residuals of the constant PSF model is generated).

d) Run again NSTAR and SUBSTAR tasks and carefully examine the results. If everything is fine generate a new image in which all the PSF stars' neighbors are subtracted but the PSF stars are present.

e) Run PSF over the neighbor subtracted image with a higher order (with varorder $=1$, two more look-up tables are generated which contain the first derivatives of the PSF with the $x$ and $y$ positions in the image).

f) Run once more NSTAR and SUBSTAR tasks and carefully examine the results. If everything is fine generate a new image in which all the PSF stars' neighbors are subtracted but the PSF stars are present.

g) Run PSF over the neighbor subtracted image with the highest order (with varor$d e r=2$, three additional look-up tables are generated containing the second derivatives with respect to $x^{2}, x y$, and $y^{2}$ of the PSF with the $x$ and $y$ positions in the image, hence a second order variable PSF has a total of six look-up tables).

h) Run for the last time NSTAR and SUBSTAR tasks, to make the last control of the results of the final PSF model ... and finally the PSF model is ready.

In the following items the most important issues regarding each of the previous steps are described:

a) Run PSF interactively to obtain a constant PSF model (with varorder $=-1$, no lookup tables are generated at this step).

To begin with, the main parameters at PSF task are:

- daopars.functio = "moffat25" $\rightarrow$ There are six functions to choose for the analytic component of the model, a few runs were made with the option "auto" which tries with the six functions and selects the one with the smallest scatter in the fit. The function moffat25 was adopted because it gave the best fit. Moffat25 
is an elliptical Moffat function ${ }^{11}$ of index $\beta=2.5$, which can be aligned along an arbitrary position angle.

- varorder $=-1.0 \rightarrow$ Is the order of variability of the PSF model. The varorder $=$ -1.0 means that the PSF is constant over the image, and has only the analytic component.

- daopars.psfrad $=11.0 \rightarrow$ Sets the region over which the PSF model is going to be defined. It is the radius at which the stellar light distribution disappears into the noise for the brightest candidate PSF star.

- daopars.fitrad $=3.0 \rightarrow$ Delimits a circle around the star, with a radius of 3.0 pixels, the pixels inside the circle will be used for computing the analytical component of the PSF model. In general the fitting radius used is approximately equal to the FWHM of the PSF.

- daopars.sannulu $=10.0 \rightarrow$ The inner radius of the sky annulus used to recompute the sky values.

- daopars.wsannul $=10.0 \rightarrow$ The width of the sky annulus used to recompute the sky values.

The basic input files in the PSF task are: the image, the photometry file, and the PSF stars list.

The output files are: the PSF image file (which contains the image of the PSF model computed), the PSF stars list (since this task was run interactively the input list may not be the same as this output list), and a 'group file' which is a list with the PSF stars and their nearest 'neighbors'12 and 'neighbors' friends' 13 .

b) Run NSTAR and SUBSTAR tasks and carefully examine the results. If everything is fine generate a new image in which all the PSF stars' neighbors are subtracted but the PSF stars are present.

The task NSTAR fits the PSF model to the sources in the input image and calculates the centers and magnitudes for all the stars in the stellar groups listed in the group file originated by the PSF task. As NSTAR fits all the stars in a group simultaneously the resulting fitting is very accurate, specially in crowded regions. For this first NSTAR run it is convenient to set the daopars.psfrad $=8.0$

The SUBSTAR task scales and shifts, for each star in the photometry list, the derived PSF model and subtracts the star from the input image.

The idea at this point is to examine basically two things: i) if there is any systematic

\footnotetext{
${ }^{11}$ A Moffat function is a modified Lorentzian function with variable power law index (Moffat, 1969).

${ }^{12}$ Neighbors stars: Stars for which $\mathrm{d}<1.5 \times$ psfrad $+2.0 \times$ fitsrad +1.0 , being $\mathrm{d}$ the distance between the centers of the PSF star and the neighbor star.

${ }^{13}$ Neighbors' friends stars: Stars for which $\mathrm{D}<2.0 \times$ fitsrad +1.0 being $\mathrm{D}$ the distance between the neighbor stars.
} 


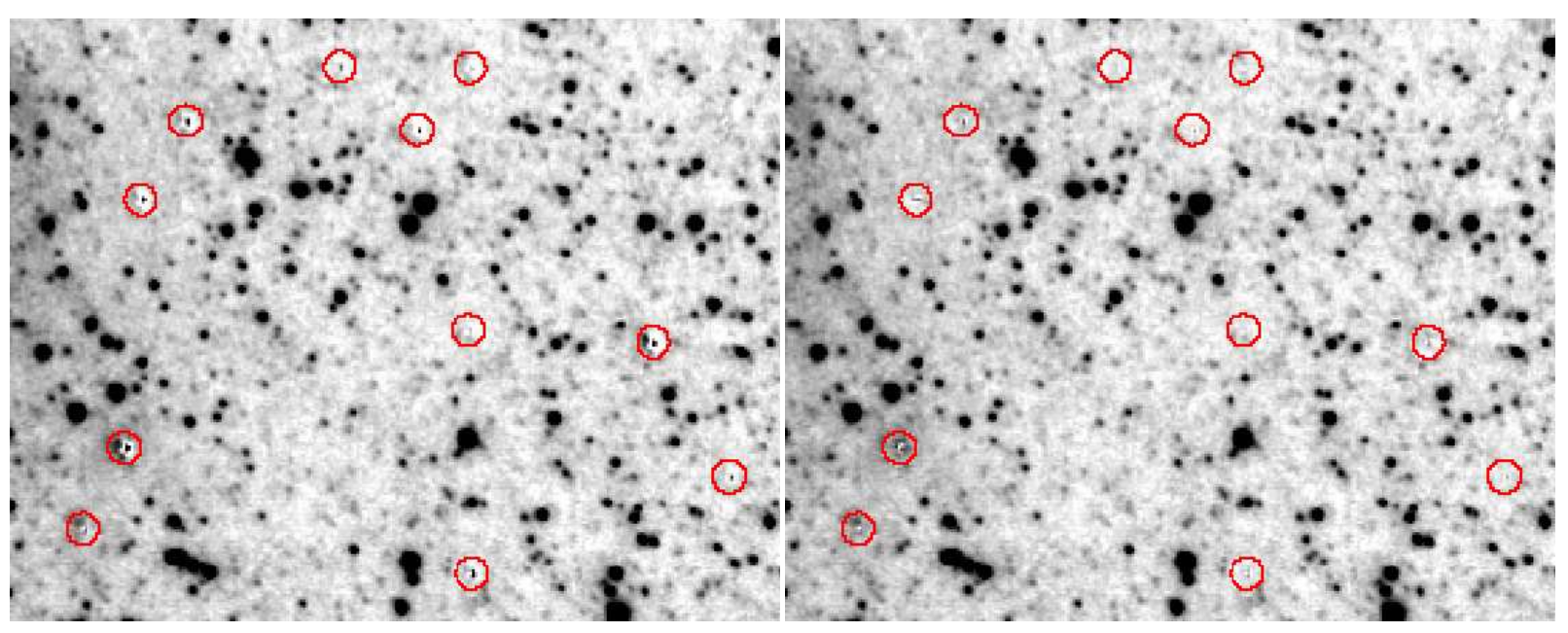

Figura 2.18: Zoomed area of the subtracted H-band image at different stages of the PSF model construction. The left panel shows the subtracted image after the first PSF fit (in step b), varorder $=-1$ ). The right panel shows subtracted image after the last iteration (in step $h$ ), varorder =2). Images are displayed with the same intensity and color scale, and the red circles mark the PSF stars positions within the image area.

residual in the image with the PSF stars subtracted (that will surely be the case at this stage because we have fitted a constant PSF), and ii) if there still remain hidden PSF neighbor stars (if this is the case, the hidden PSF neighbors stars must be added in the phot list file, the PSF star must be excluded from the PSF stars' list, and this step should be repeated).

When no hidden PSF neighbor stars are found, the task SUBSTAR is run again, but with the group file as an input phot file and the PSF star list as an 'exfile' (a photometry file containing stars to be excluded from the subtraction), in this way, we generate an image with PSF stars but without their neighbors, which will be used as an input image for the next run of the PSF task.

Steps c) to $h$ ) involve an iterative repetition of steps a) and b), every time with a higher varorder, until varorder $=2$ is reached. Figure 2.18 shows a zoomed area of the subtracted $H$-band image at different stages of the PSF model construction. The left panel shows the subtracted image after the first PSF fit (in step b), varorder $=-1$ ), the right panel shows a subtracted image after the last iteration (in step h), varorder $=2$ ), the images are displayed with the same intensity and color scales, and the red circles mark the PSF stars positions within the image area. The improvement in the PSF stars' subtraction, and hence the PSF model, is evident.

Figure 2.19 exhibits different views for the final PSF model for an hypothetical object in 

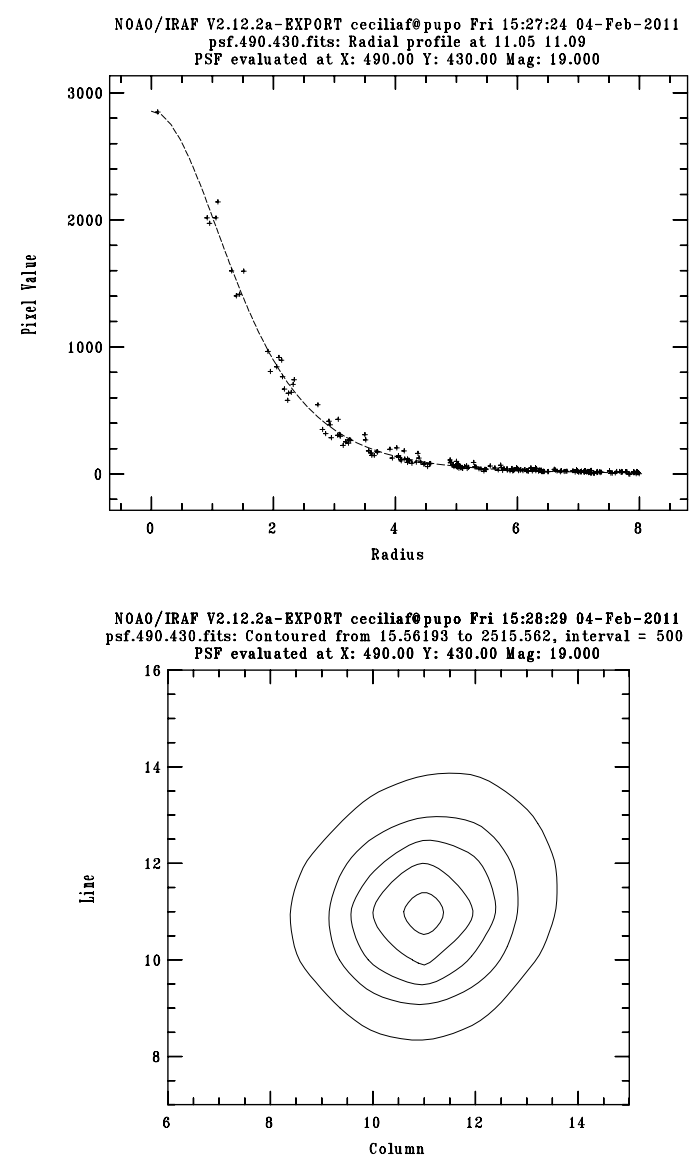

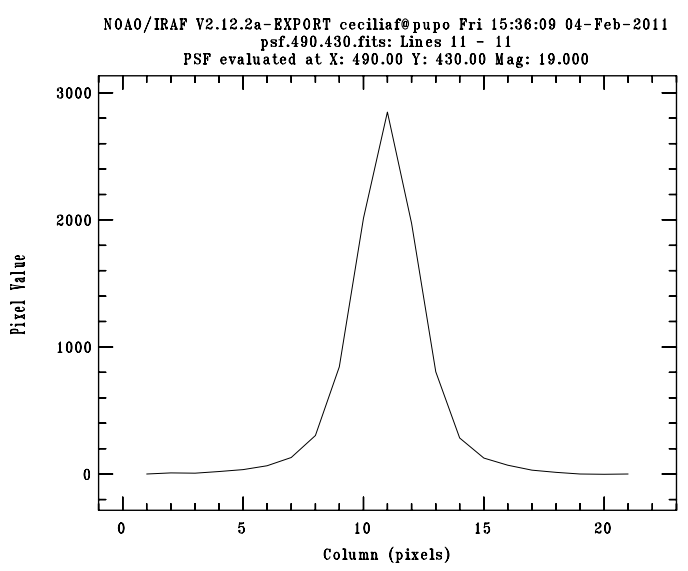

N0A0/IRAF V2.12.2a-EXPORT ceciliaf@pupo Fri 15:22:49 04-Feb-2011 psf.490.430.fits: Surface plot of $[1: 21,1: 21]$
PSF evaluated at X: $490.00 \mathrm{Y}: 430.00 \mathrm{Mag}: 19.000$

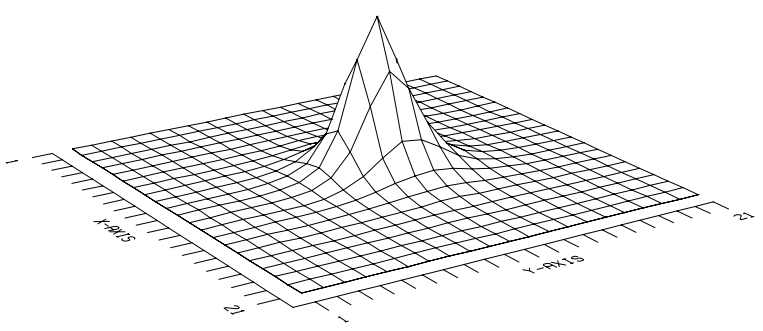

Figura 2.19: Different views for the final PSF model for the J filter, for an hypothetical object of magnitude $j=19.0$, located at the image center, pixels $x=490, y=430$. A radial profile and line plots are shown in the upper left and right panels, respectively; the bottom left and right panels exhibit a contour and a surface plots, respectively.

the $J$ image, of magnitude $j=19.0^{14}$, located at the image center, pixels $x=490, y=430$ (note that the PSF profile can vary with the position in the image). The PSF image was displayed with the SEEPSF task and examined with the IMEXAMINE task. A radial profile and line plots are shown in the upper left and right panels, respectively; the bottom left and right panels exhibit a contour and a surface plots, respectively.

\section{Apply the PSF model to all the stars in the list and subtract the fitted stars}

Once the PSF model is generated it has to be applied to all the stars in the phot list. The

\footnotetext{
${ }^{14}$ In this Thesis, the lowercase fonts $(\mathrm{j}, \mathrm{h}$, and $\mathrm{k})$ are used to refer to the magnitudes that are not necessarily in a standard system.
} 
best option to do this is running the ALLSTAR task, which groups, fits, and subtracts the fitted stars from the input image, using the calculated PSF model and the phot file.

Figure 2.20 shows, for visual comparison, the original image and the final image (with all the stars subtracted) for the three JHKs filters. The subtracted images exhibit, as was expected, the large-scale nebular emission, with the exception of a few extended or very bright objects. The remnant extended objects did probably not fulfill the geometrical conditions to be considered stars, being rejected either by the ALLSTAR algorithms or directly not included in the initial phot list. The very bright objects are saturated sources which were rejected by the ALLSTAR fitting algorithms. The white spots in the intense nebular emission reflects the difficulty to obtain a unique sky value in regions with intense and highly variable nebular emission. For this reason in the ALLSTAR task, the groupsky parameter, which computes the sky value for each group by averaging the individual sky values in the phot file for all the stars within the group, was set to "no". Instead, the sky value was recalculated for each star individually and then, the sky value for each pixel which contributes to the group fit, was set equal to the mean of the sky values for those stars for which the pixel falls within one fitting radius. Recomputing the sky in this way significantly reduces the scatter in the magnitudes for objects within regions where the sky background is varying rapidly, as is the case in the central region of the NGC 604 field.

The ALLSTAR task was allowed to recenter the stars, which means that ALLSTAR calculates the best coordinates for each object according to its PSF fit. In Davis (1994), is commented that recentering the stars at this stage is almost always the best choice, and can be avoided only in the case that the initial coordinates in the input photometry file are known to be very accurate (e.g. derived from a better seeing image). In our case, recentering the stars was strictly necessary since the original objects' coordinates were derived from a created $J+K_{s}$ image, which could result in not accurate centers due mainly to: a) minor residual shifts remnant from the alignment process of the $J$ and $K_{s}$ images and b) because for some sources the emission in $K s$ is can be not exactly coincident with the emission in $J$, it should be considering pure stellar objects but in case were the objects have $K s$ nebular emission associate with them it can be that the emission in both filters exhibits small shifts and/or also differences in spatial extension, resulting in a slightly different center position in both images.

As a result of the process described in this Section, three files with the stellar magnitudes in JHKs-bands were obtained. The ALLSTAR output file basically contains the objects internal identity number, the $(x, y)$ objects' center positions, the instrumental magnitudes measured and their errors, the sky values, the iteration numbers in which each object's fit converged, and two 


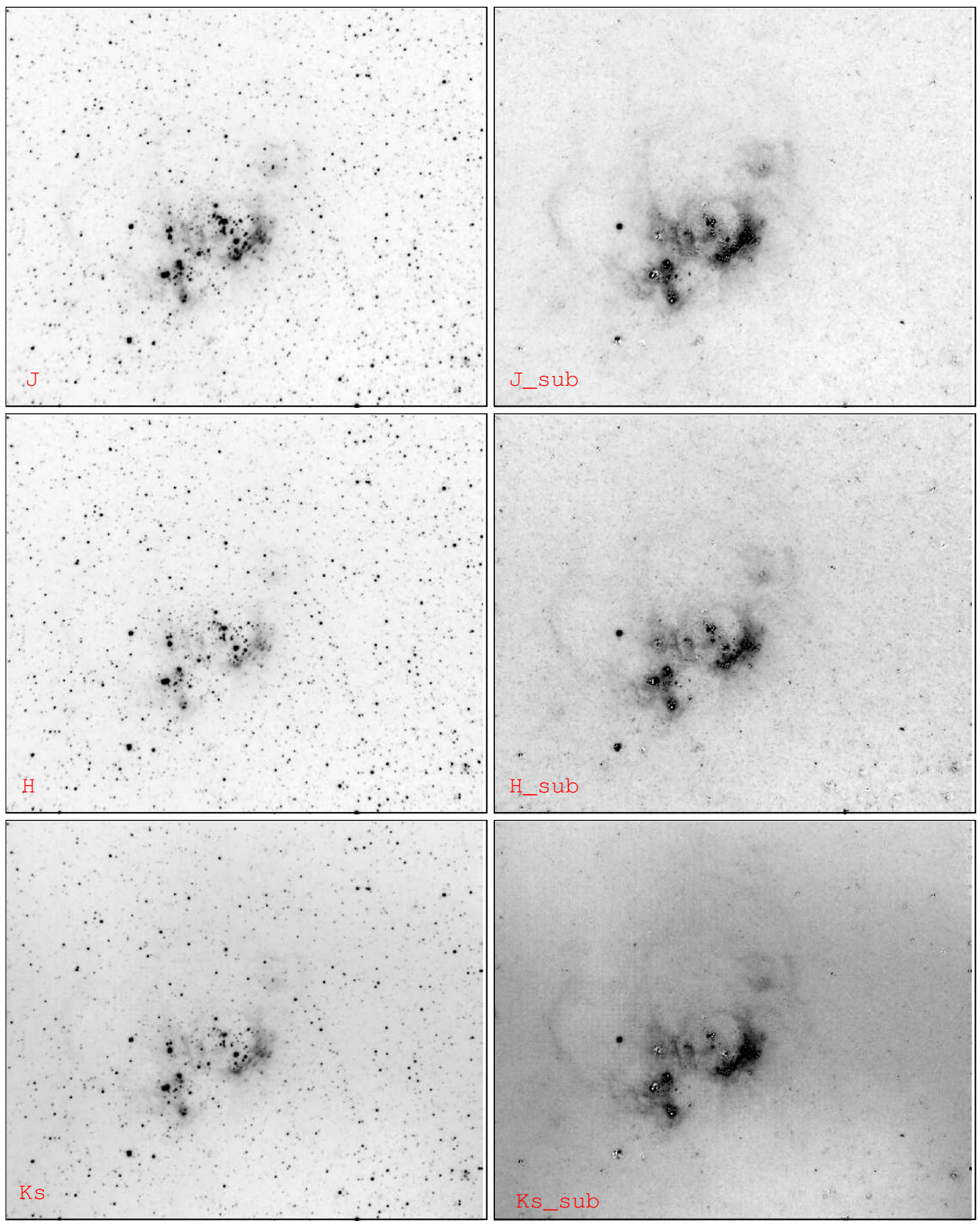

Figura 2.20: The original image and the final image with all the stars subtracted for the three JHKs filters after running ALLSTAR task. 
values called sharpness and chi $(\chi)$ that will be referred in the next Section.

From the initial value of 4729 objects found in the $J+K s$ image, we obtain, by PSF fitting photometry, the instrumental magnitudes for 4621 objects in the $J$-band, 4570 in the $H$-band, and 4540 in the $K s$-band. The three tables were matched in a unique table that contains the instrumental magnitudes (and other meaningful quantities) in the three filters. This was done using the task MKOBSFILE; the tolerance (in pixels) for matching objects in the three filters was set in 3.0 pixels, since it was the value for the stellar FWHM and broad-band images seeing. This yield a total of 4429 objects with magnitudes measured in the three filters.

\subsection{The ' $\chi$ problem'}

As was said in the precedent Section, there are two parameters in the final photometry table that contain information linked with the 'quality ' of the fit for each object. One of these quantities, called sharpness, is related to the star's shape, and is a measure of the difference between the square of the width of the object and the square of the width of PSF. Stars should have sharpness values $\sim 0.0$, undersampled objects, as cosmic rays, have sharpness values $<<$ 0.0 , and extended objects have sharpness values $>>0.0$. Figure 2.21 shows the distribution of sharpness values with the magnitudes for the three filters. As was expected the values exhibit scatter around 0.0 and there is a reasonable scatter trend to values $>0.0$ at all magnitudes due to the presence of extended high nebular emission. The scatter is larger moving towards higher magnitude levels.

The other quantity related with the 'quality' of the fit for each object, is called Chi $(\chi)$, and is the goodness of fit statistics. It essentially measures the ratio of the observed pixel-to-pixel scatter in the fitting residuals to the expected scatter. A plot of $\chi$ versus magnitude should scatter around unity with little or no trend in $\chi$ with magnitude, except at the bright end where saturation effects may be present. Figure 2.22 shows the $\chi$ values' distribution with the magnitudes for the three filters. As it is evident, the mean value is not around 1.0 but around 0.2. Although the mean value is shifted, the shape of the distribution is correct.

To elucidate the reason why the $\chi$ values exhibit a systematic shift, the model used to calculate the expected scatter was carefully analyzed and several test were performed, as explain in the following paragraphs.

The expected scatter in the fitting is dependent on the DATATPARS task parameters: readnoise and epadu, and the DAOPARS parameters: flaterr and proferr, thorough the error model as follows: 


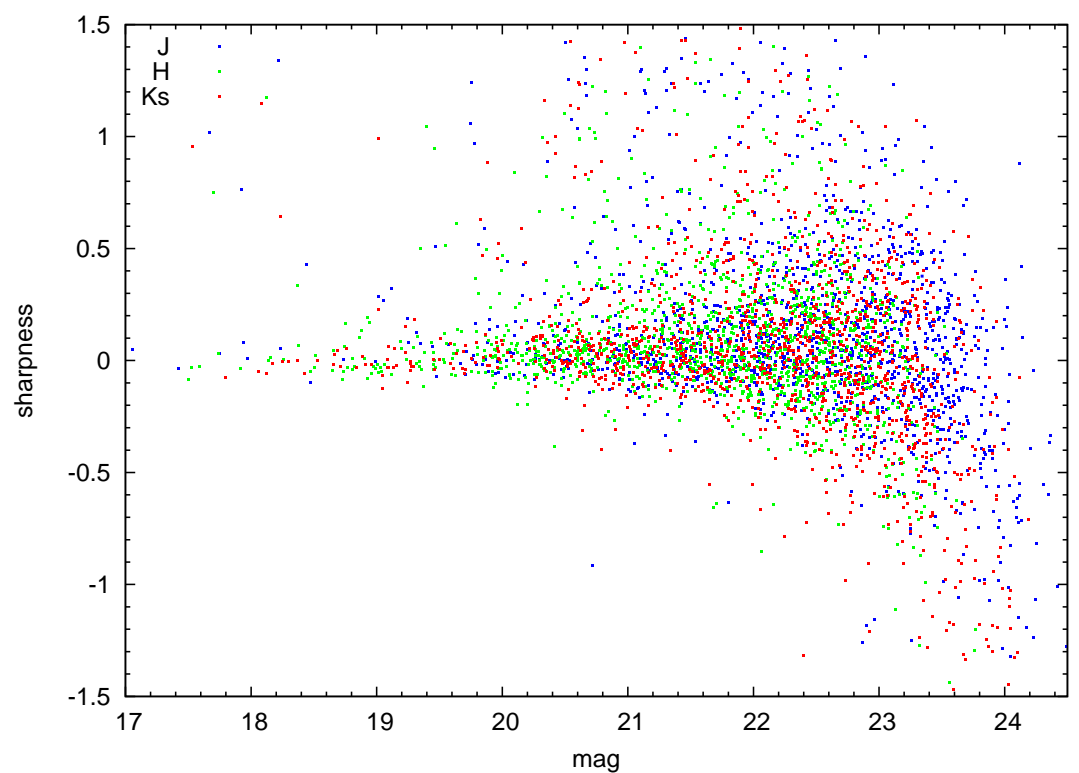

Figura 2.21: Sharpness values distribution with the magnitudes for the JHKs bands. As was expected the values exhibit scatter around 0.0 and there is a reasonable scatter trend to values $>$ 0.0 at all magnitudes due to the presence of extended high nebular emission. The scatter is larger moving towards higher magnitude levels.

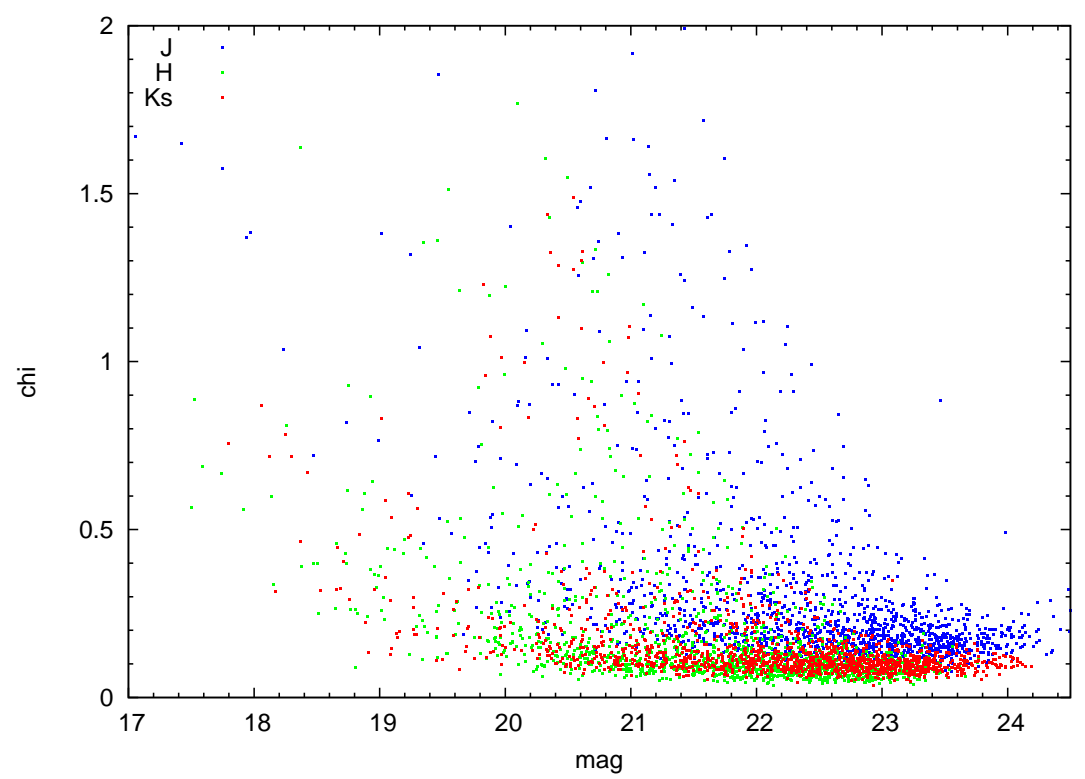

Figura 2.22: $\chi$ values' distribution with the magnitudes for the for the JHKs bands. As it is evident, the mean value is not around 1.0 but around 0.2. Although the mean value is shifted, the shape of the distribution is correct. 


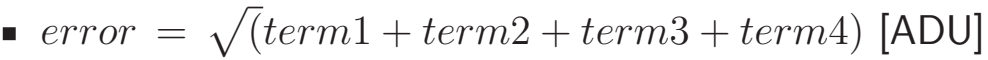

- term $1=(\text { readnoise } / \text { epadu })^{2} \rightarrow$ the readout noise

- term $2=I /$ epadu $\rightarrow$ the poisson noise

- term $3=(0.01 \times \text { flaterr } \times I)^{2} \rightarrow$ the flatfielding error

- term $4=\left(\frac{0.01 \times \text { proferr } \times M}{(p 1 \times p 2)}\right)^{2} \rightarrow$ the interpolation error

where:

readnoise $\rightarrow$ effective readout noise in electrons

epadu $\rightarrow$ effective gain in electrons per ADU

$\mathrm{I} \rightarrow$ pixel intensity in ADU

$\mathrm{M} \rightarrow$ PSF model intensity in ADU

$\mathrm{p} 1 \rightarrow$ FWHM in $\mathrm{x}$ in pixels

p2 $\rightarrow$ FWHM in y in pixels

According to Davis (1994) the $\chi$ value should be $\sim 1.0$. If it is not, then:

1. The object is not a single star.

2. The PSF model is a poor representation of the true PSF.

3. The noise model including one or more of the gain, readout noise, flat-fielding error, and interpolation error parameters for the image are incorrect.

4. The input image does not conform to the requirements of the DAOPHOT package.

Reason 1) is, of course, not applicable to all the objects, and reason 2) is discarded since there are many indicators that the PSF model fits good (as the clean subtracted images, and the normal error and sharpness distributions). Reasons 3) and 4) seem more applicable to our case.

For testing reason 3) the parameters gain and rdnoise were carefully controlled, and the results obtained by the DAOPHOT tasks were checked calculating manually the values of gain and readout noise every time an operation with the images was done (as for example after running the IMCOADD task). Some other checks were done by changing the values for the fractions of flaterr and proferr in the previous formulas, with no reasonable results.

Other tests were made by subtracting the mean sky value to the image, also adding linear combinations of quantities following some criteria, without improving the results.

Therefore, we decided to start the tests at the very beginning of the reduction process, hence the task ALLSTAR was run in a single reduced image (the image before being combined by IMCOADD). As was expected, the scatter of $\chi$ was huge but the $\chi$ mean value was still shifted. ALLSTAR was also run in a single image which had not been reduced yet (only the very basic task, NPREPARE, was previously applied). In this opportunity, the mean $\chi$ value was around 1.0 (again with a huge scatter). The results of this test are shown in Figure 2.23 where the top plot exhibits the $\chi$ values versus magnitudes for the single reduced image (first case), 

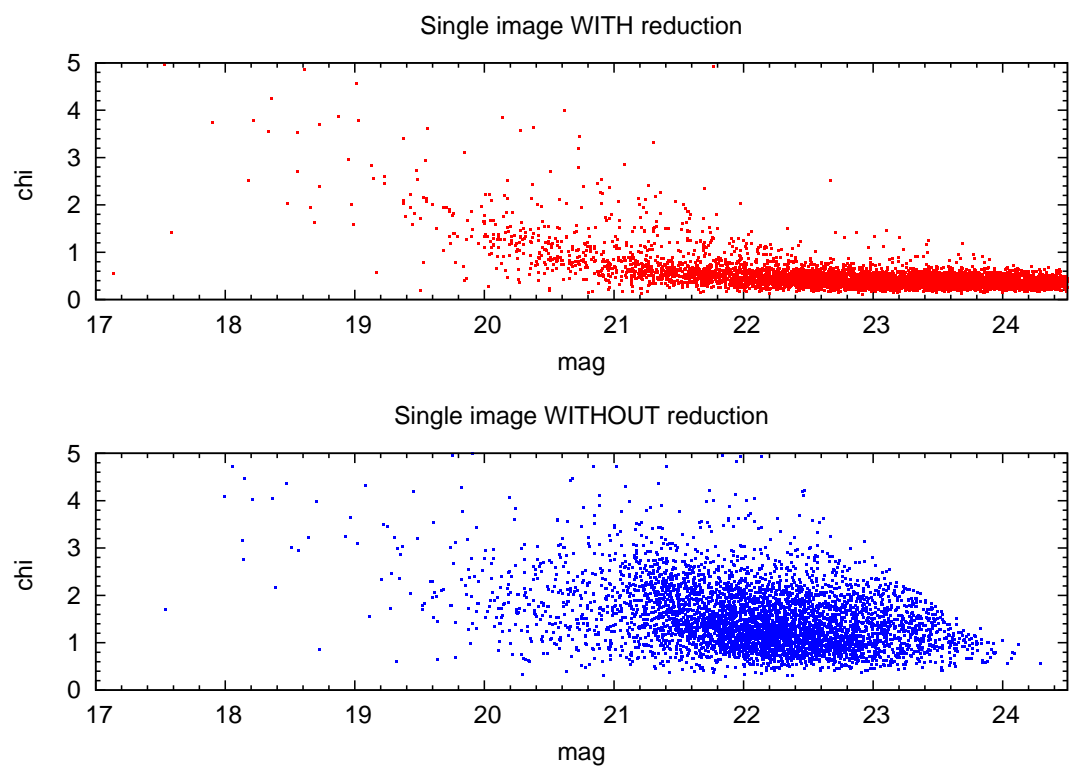

Figura 2.23: $\chi$ values distribution with the magnitudes resulted from run sc allstar on single images. Top plot exhibits the $\chi$ values versus magnitudes for the single reduced image (first case), and the bottom panel the $\chi$ values resulting from run ALLSTAR in a single not reduced image. Although the distribution exhibits a huge scatter (which is reasonable considering that nor flat fielding and neither sky subtraction were done to the image) the values are clearly scattered around 1.0 .

and the bottom panel the $\chi$ values resulting from run ALLSTAR in a single not reduced image. Although the distribution exhibits a huge scatter (which is reasonable considering that nor flat fielding and neither sky subtraction were done to the image) the values are clearly scattered around 1.0. The conclusion derived from these results is that in the reduction process some operation is done that alters the values used for quantify the expected scatter with the model, in such a way that results in their overestimation. That it why the $\chi$ value, which is the ratio of the observed pixel-to-pixel scatter in the fitting residuals to the expected scatter in shifted to lower valuer.

Gemini staff (and Gemini-NIRI staff particularly) was consulted regarding to these results. They were not aware of this situation before, and even thought they could reproduce our results they could not help us with a certain explanation of the reason that cause this shift in the $\chi$ mean values.

It is important to make it clear that the shift in the mean $\chi$ values does not really affect any result of the PSF magnitudes fitting and its reliability. There are several instances were the magnitudes were checked and no systematic errors were found. In the next Chapter some of these 'checking tests' are going to be reviewed and explained, as the experiment adding fake stars, the comparison with magnitudes in the literature, etc. 


\subsection{To the standard system photometry}

The standard stars' magnitudes were calculated with aperture photometry (using the PHOT task) with an aperture of radii $=20$ pixels (which is $\sim 7 \times \mathrm{FWHM}$ ). This value was considered the appropriate after performing aperture photometry with different apertures (at the three bands) and generating the growth curves with the MKAPFILE task.

To calibrate the measured PSF fitting instrumental magnitudes it is necessary to obtain the stars' magnitudes as close as possible to the magnitudes that would be measured for them at an aperture of radii $=20.0$ pixels (as the standard stars were measured). This can be done by calculating the aperture correction of the field stars which, similarly to the aperture photometry, takes into account the stellar flux left outside the fitting radii. Hence, it is a quantity to be added to the fitted instrumental magnitude, and of course, it has to be a negative value (then the corrected stars' magnitudes are smaller (brighter stars) than the originally measured with the smaller aperture).

The correction aperture for a variable PSF model has to be computed using stars in the science frame. Several stars for each band ( 35 for $J, 55$ for $H$, and 65 for $K s$ ) were chosen well spread in the science frame. Most of the chosen stars were coincident with the PSF stars. Neighbor stars of the selected stars were subtracted to obtain a more accurate estimation of the aperture correction. Figure 2.24 exhibits an $H$-band image in which the selected stars to calculate the aperture correction were mark with red circles. The circles have a radii of 20.0 pixels and the neighbor stars within this radii were subtracted for each chosen star. Growth curves were generated with the MKAPFILE for these stars to corroborate that the radii $=20.0$ pixels chosen for the standard stars was also a good radii for the science stars.

Figure 2.25 exhibits, as an example, part of the output meta code file of the MKAPFILE task for the $J$ standard star (left panels) and the field stars selected to calculate the aperture correction (right panels). Top left panel shows the plot of the final curve of growth model fit for the standard $J$ star, from the smallest radii considered for the aperture photometry 3.0 to the highest value at 33.0 pixels. It can be observed that the growth curve stabilizes at values around 20.0 and then it starts to grow again due to noise. Bottom left panel shows the residuals for the fit with the radii. The top right panel shows the plot of the final curve of growth model fit from the smallest radii considered for the aperture photometry 3.0 to the highest value at 20.0 pixels (considered for the standard stars). The aperture correction was calculated with the MKAPFILE task and the results were compared with the mean value obtained from the aperture magnitudes at radii $=20.0$ minus the PSF fitting magnitudes at radii $=3.0$. Table 2.7 list the obtained aperture correction values.

The standard stars were used to calculate the constants for the transformation equations for each filter. The equations used were: 


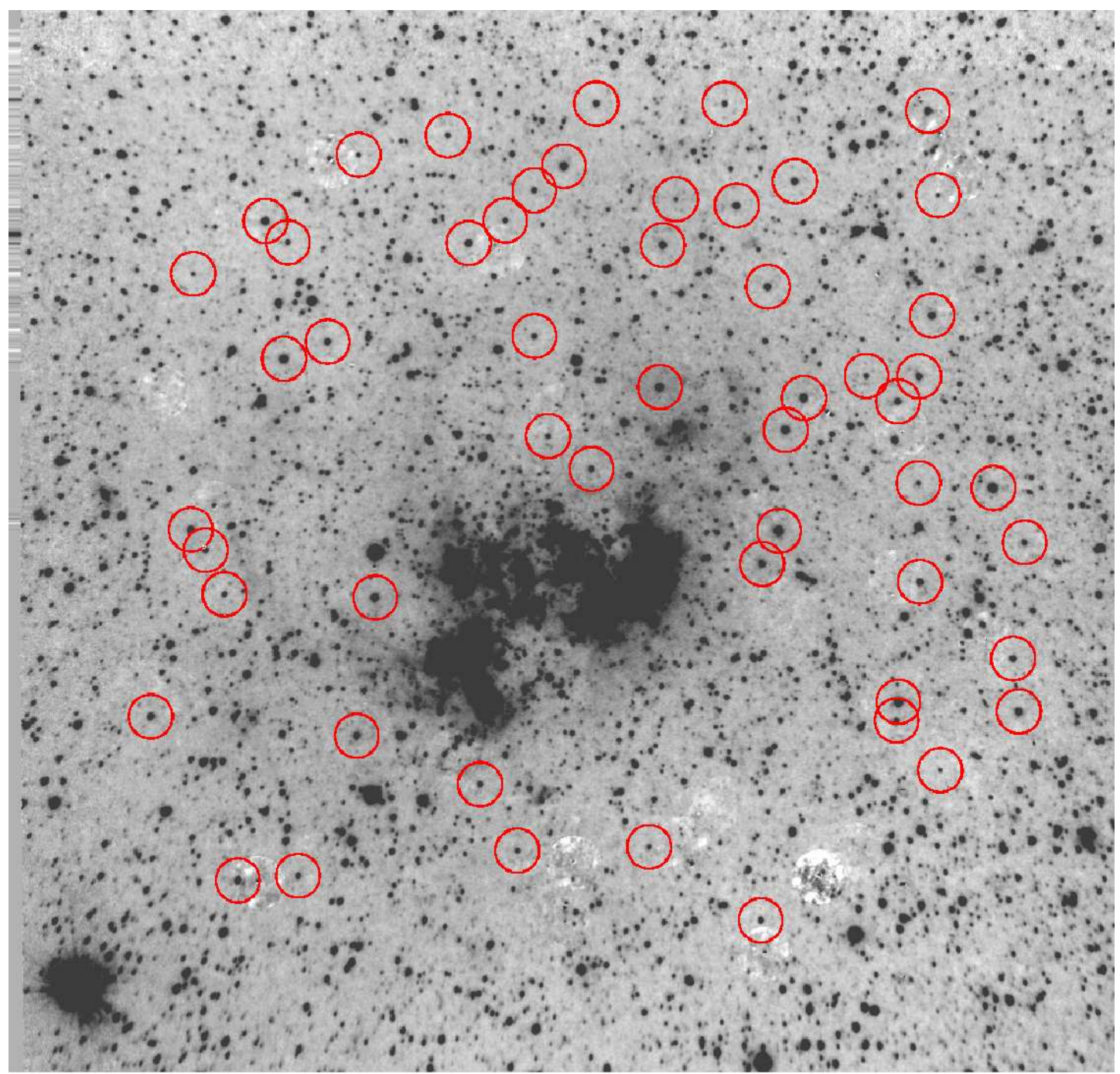

Figura 2.24: H-band image, in which the selected stars to calculate the aperture correction were marked with red circles. The circles have a radius of 20.0 pixels and the neighbor stars within this radius were subtracted for each chosen star. 

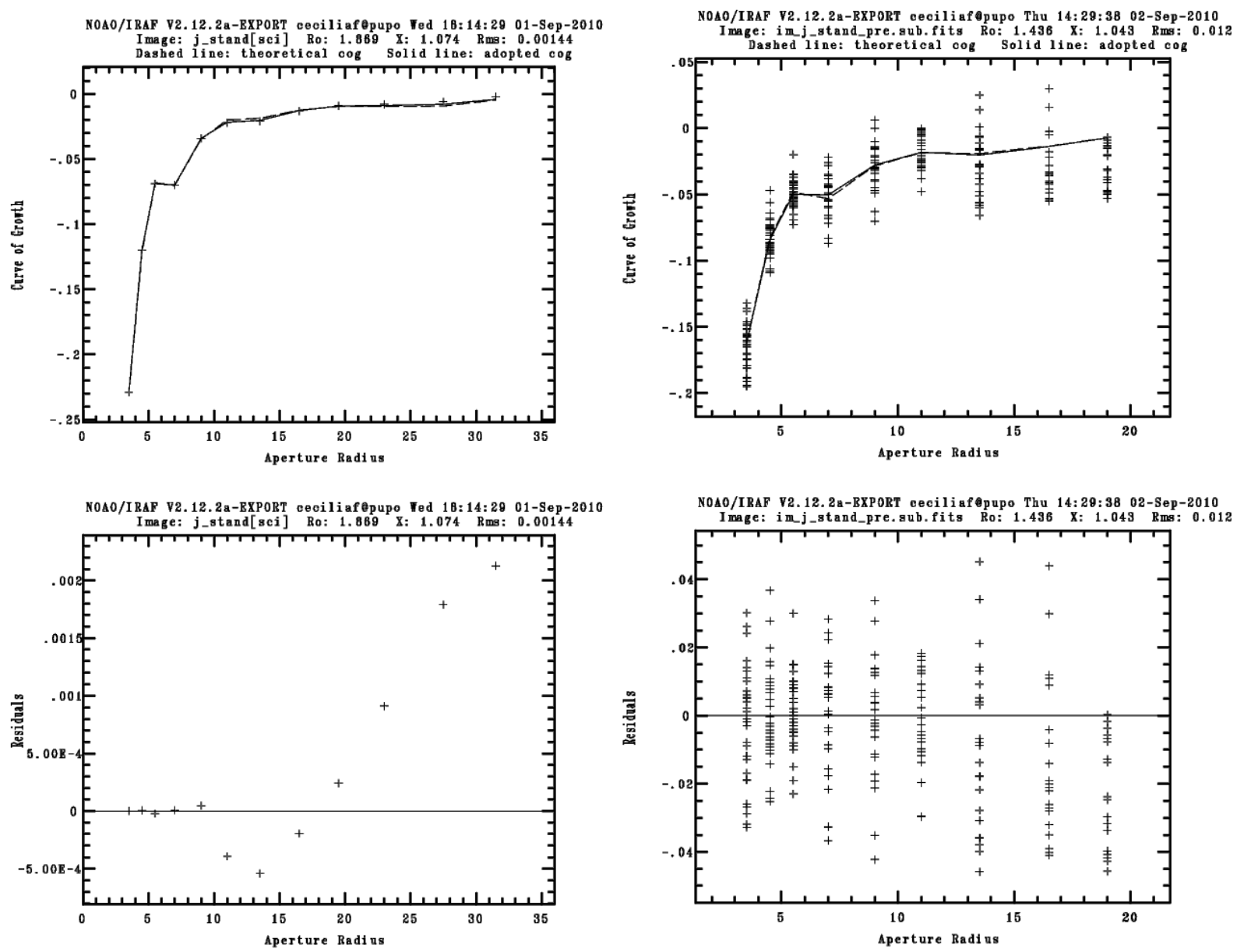

Figura 2.25: Part of the output meta code file of the MKAPFILE task for the $J$ standard star (left panels) and the field stars selected to calculate the aperture correction (right panels). Top left panel shows the plot of the final curve of growth model fit for the standard $J$ star, from the smallest radii considered for the aperture photometry 3.0 to the highest value at 33.0 pixels. It can be observed that the growth curve stabilizes at values around 20.0 and then it starts to grow again due to noise. Bottom left panel shows the residuals for the fit with the radii. The top right panel shows the plot of the final curve of growth model fit from the smallest radii considered for the aperture photometry 3.0 to the highest value at 20.0 pixels (considered for the standard stars). 


\begin{tabular}{ccccc}
\hline Filter & Apercor & Constant & Extintion & Airmass \\
\hline$J$ & $-0.39 \pm 0.02$ & $1.087 \pm 0.008$ & 0.015 & 1.026 \\
$H$ & $-0.33 \pm 0.02$ & $0.992 \pm 0.011$ & 0.015 & 1.048 \\
$K s$ & $-0.34 \pm 0.02$ & $1.518 \pm 0.024$ & 0.043 & 1.043 \\
\hline
\end{tabular}

Table 2.7: Aperture correction values and transformation constants from instrumental magnitudes to MKO system for each broad-band filter.

$$
\begin{aligned}
& \text { const }_{J}=j-J-\text { extinction } \times \text { airmass } \\
& \text { const }_{H}=h-H-\text { extinction } \times \text { airmass } \\
& \text { const }_{K_{s}}=k s-K_{s}-\text { extinction } \times \text { airmass }
\end{aligned}
$$

Where the capital letters were used for the magnitudes in the standard system and lowercase letters were used the measured instrumental magnitudes, up to a radii of 20 pixels. The standard stars magnitudes were taken from UKIRT Mauna Kea Observatory Photometric Standards catalog (1 to $5 \mu \mathrm{m}$ at $J, H, K, L^{\prime}$, and $M$, Leggett et al. (2006), Leggett et al. (2003)).

Finally, the transformation to the standard magnitude system for all the stars was performed with the TCALC task used to calculate the following equations:

$$
\begin{aligned}
& J=\left(j+\text { apercor }_{j}\right)-\text { const }_{J}-\text { extinction } \times \text { airmass } \\
& H=\left(h+\text { apercor }_{h}\right)-\text { const }_{H}-\text { extinction } \times \text { airmass } \\
& K_{s}=\left(k s+\text { apercor }_{k s}\right)-\text { const }_{K_{s}}-\text { extinction } \times \text { airmass }
\end{aligned}
$$

The aperture correction values together with the transformation constants, extinction, and airmass values are listed in Table 2.7 .

The derived magnitudes are on the MKO infrared photometric system. Although, during the analysis of the JHKs photometry data it was noticed that the objects' positions were slightly systematically shifted in the CC and CM diagrams, meaning that the magnitudes have a zero point systematic shift. Hence, we looked for a way to check the zero points of our magnitudes. A simple (and the most accurate) way to do it would have been by making a direct comparison with our photometry and 2MASS photometry (trough the photometric system transformation), but it was not possible as the magnitude limits of 2 MASS at SNR $=10$ are 15.8, 15.1, and 14.3 for $J, H$, and $K s$ filters respectively, which are the stars that saturate in our images. Nevertheless, a comparison was possible by means of a study published by Cioni et al. (2008). The authors performed wide-field $J H K_{s}$ observations of M 33 using WFCAM at UKIRT, referring the astrometric and photometric calibration on the 2MASS point source catalog. Fortunately, there are 10 sources in common with our sources which gave us the chance to compare their 


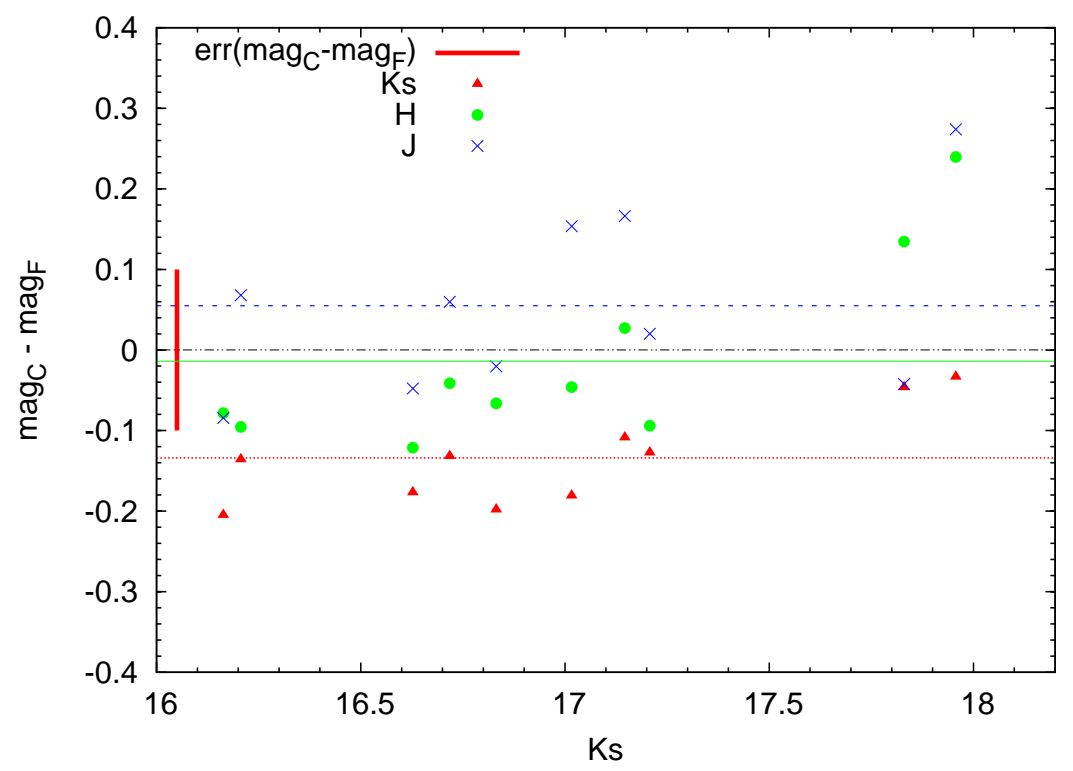

Figura 2.26: Comparison between our photometric results and Cioni et al. (2008) for the J, H and Ks filters,for the set of stars in common. The presence of small magnitude offsets between both sets can be seen. We performed a simple average to estimate these offsets and found them to be 0.05,-0.01 and -0.13 magnitudes for $J, H$, and Ks respectively. The applied offsets were marked as horizontal lines in Figure ??, the vertical red line in the left corner represents the error propagation for the magnitudes' subtraction

magnitudes with ours by transforming our magnitudes to the $2 \mathrm{MASS}^{15}$.

The results of the comparisons are shown in Figure ?? for the $J, H$ and $K s$ filters, for the set of stars in common. The presence of small magnitude offsets between both sets can be seen. As no additional trend becomes evident and being the number of stars to compare small, we performed a simple average to estimate these offsets and found them to be $0.05,-0.01$ and -0.13 magnitudes for $J, H$, and $K s$ respectively. The applied offsets were marked as horizontal lines in Figure ??, the vertical red line in the left corner represents the error propagation for the magnitudes' subtraction. Although individually small, they add up to one tenth of a magnitude in the $(H-K s)$ color. These offsets were added to the zero-points calculated for our photometry. The errors of applying these offsets derived from the comparison in the 2MASS system directly in the magnitudes of the MKO system are smaller than the order of the photometric errors.

The errors in the final standard magnitudes were estimated by the error standard propagation: $\operatorname{magErr}=\sqrt{\left(e r r_{\text {mag }}^{2}+e r r_{\text {apercor }}^{2}+e r r_{\text {const }}^{2}\right)}$

\footnotetext{
${ }^{15}$ The color transformations used are at http : //www.astro.caltech.edu/ jmc/2mass/v3/transformations/
} 


\begin{tabular}{|c|c|c|c|c|c|c|c|c|c|c|}
\hline $\begin{array}{c}\text { Object } \\
(1)\end{array}$ & $\begin{array}{c}\alpha(\mathrm{J} 2000.0) \\
(2)\end{array}$ & $\begin{array}{c}\delta(\mathrm{J} 2000.0) \\
(3)\end{array}$ & $\begin{array}{c}J \\
(4)\end{array}$ & $\begin{array}{l}\sigma_{J} \\
(5)\end{array}$ & $\begin{array}{c}H \\
(6)\end{array}$ & $\begin{array}{l}\sigma_{H} \\
(7)\end{array}$ & $\begin{array}{l}K s \\
(8)\end{array}$ & $\begin{array}{c}\sigma_{K_{s}} \\
(9)\end{array}$ & $\begin{array}{l}J-H \\
(10)\end{array}$ & $\begin{array}{c}H-K s \\
(11)\end{array}$ \\
\hline NGC604-1 & 23.633 & 0.769 & 20.9 & & 20.40 & & 20.36 & 0 & 0.50 & 0.04 \\
\hline $\mathrm{N}$ & 3.6215 & 2 & 20 & & 19 & & 19 & & 0. & 0.19 \\
\hline NGC6 & 639 & 30.769 & 19.48 & 0.02 & 18.84 & 0 . & 18.53 & 0. & 0.64 & 0.31 \\
\hline$\ldots$ & $\ldots$ & $\ldots$ & $\cdots$ & $\ldots$ & $\ldots$ & $\ldots$ & $\cdots$ & $\cdots$ & $\cdots$ & $\cdots$ \\
\hline
\end{tabular}

Table 2.8: Excerpt of the final photometry table available at electronic format at http://fcaglp.fcaglp.unlp.edu.ar/ ceciliaf/thesis/JHKphotometry.tab. Column 1 lists the internal objects Id., Columns 2 and 3 the celestial coordinates $\alpha$ and $\delta$, respectively, Columns $4-9$ contain the measured J, H, and Ks magnitudes and errors, Column 10 and 11 list the colors J-H, H-Ks, respectively.

The errors in the air mass and extinction were not included in the calculation since they were an order of magnitude smaller than the aperture correction error.

Table 2.8 is an excerpt of the final photometry table which is available at electronic format at http://fcaglp.fcaglp.unlp.edu.ar/ ceciliaf/thesis/JHKphotometry.tab. Column 1 lists the internal objects Id., Columns 2 and 3 the celestial coordinates $\alpha$ and $\delta$, respectively, Columns 4 9 contain the measured $J, H$, and $K s$ magnitudes and errors, Column 10 and 11 list the colors $J-H, H-K s$, respectively. 


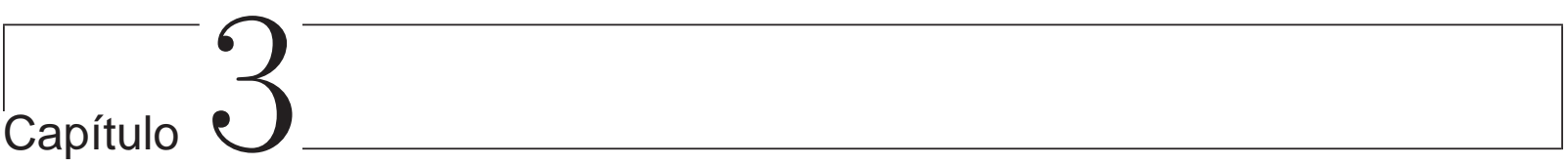

\section{Análisis y resultados derivados de los datos de banda ancha}

\subsection{Introducción}

En este Capítulo se describe el análisis realizado y los resultados obtenidos con los datos derivados de la fotometría de banda ancha de Gemini-NIRI en los filtros $J, H$ y $K s$. Los resultados aquí presentados constituyen el aporte más importante y novedoso de esta Tesis al estudio de NGC 604.

El presente Capítulo contiene las siguientes Secciones: • La 'región central' y la 'región de campo' de NGC 604: explica cómo se definió el límite entre dichas regiones; • Sobre el error interno de la fotometría: detalla el análisis llevado a cabo para examinar los errores fotométricos; - Sobre la completitud de la fotometría: describe las magnitudes límites para la completitud de la fotometría; • Diagramas color-color y color-magnitud: describe los diagramas generados a partir de la fotometría JHKs y el análisis de las particularidades de los objetos en dichos diagramas; - Contaminación por objetos de campo: describe las diferencias entre los diagramas obtenidos para la región central de NGC 604 y la región del campo control; • Distribución espacial de los objetos con exceso IR: describe la ubicación de las fuentes con exceso IR en el campo de NGC 604 y el análisis de la distribución de dichos objetos en el contexto de los resultados de los estudios previos; - Fracción de objetos con exceso IR: describe el cálculo de la fracción (total y por regiones) de objetos con exceso IR en NGC 604 y su comparación con los resultados obtenidos para regiones de formación estelar galácticas; • Objetos individuales estudiados previamente: lista algunos de los objetos individuales que fueron estudiados previamente en la región y sus características en la fotometría JHKs de Gemini-NIRI. 



\subsection{La 'región central' y la 'región de campo' de NGC 604}

El presente Capítulo comienza con una definición precisa de dos zonas en el campo de NGC 604 de las imágenes de Gemini-NIRI, a las cuales se hará referencia en lo sucesivo como la 'región central' y la 'región de campo' de NGC 604.

Dada la compleja estructura espacial de NGC 604 resulta difícil atribuirle un área claramente definida a la región. Por otro lado, el área ocupada por la región dependerá de los datos que se estén considerando para definirla. De este modo, por ejemplo, Israel \& van der Kruit (1974) definen, utilizando datos en radio $(1415 \mathrm{MHz})$, que la estructura nebular de NGC 604 está compuesta por un núcleo de 48 pc y un halo de 380 pc de diámetro, en tanto que Sandage \& Tammann (1974), con datos de placas fotográficas (con filtro en $\mathrm{H} \alpha$ ), le asignan un diámetro de 224 pc al núcleo y de 436 pc al halo. Entre medio de estos dos valores, en su estudio de la población estelar de masa intermedia de NGC 604, Hunter et al. (1996) han considerado, de acuerdo a sus datos, un diámetro de $\sim 115$ pc para el cúmulo estelar central de NGC 604.

En particular, para el presente estudio, es necesario definir un área central para NGC 604, principalmente para dar cuenta de la 'contaminación' debida a la presencia de objetos en la línea de la visual a NGC 604, ubicados tanto delante como detrás de la región (los cuales en proyección se encuentran en el campo de NGC 604).

En el Capítulo 1 se hizo referencia al hecho de que el cúmulo central de NGC 604 presenta una estructura denominada SOBA por su semejanza a la estructura de las Asociaciones OB, cuyas estrellas están dispersas ocupando una región proyectada muy extendida, en contraste por ejemplo, a la estructura de los SSCs. La estructura 'abierta' de NGC 604 conlleva dos consecuencias importantes para los estudios observacionales. Por un lado, resulta más sencillo resolver sus objetos individuales ya que se observan espacialmente (en proyección) separados $y$, considerando la distancia a la que se encuentra NGC $604(1 "=4.1$ pc) resulta un factor esencial para su estudio. Por el otro lado, es más difícil definir los límites del cúmulo basados en la sobredensidad de objetos de NGC 604 respecto al conteo de objetos de fondo, ya que dicha sobredensidad no es evidente. En la Figura 3.1 se muestran los histogramas del número de objetos respecto a las coordenadas, ascención recta (RA, en el panel superior) y declinación (Dec, en el panel inferior), las líneas negras representan el límite de la región definido mediante los contornos de $P a \beta$ según se explica en el siguiente párrafo. En dichos gráficos se observa que no existe una sobredensidad ostensible definida por la presencia del cúmulo central de NGC 604 .

Dada la imposibilidad de especificar un límite para la región central de NGC 604 y la región de objetos de campo a partir de ahora se hará referencia a estas regiones como la 'región central' y la 'región de campo' respectivamente) en base a conteos estelares, se decidió utilizar algún tipo de límite trazado por la emisión nebular de la región, de modo que se recurrió a las imágenes de banda angosta. Una forma posible para definir la región central es considerar 

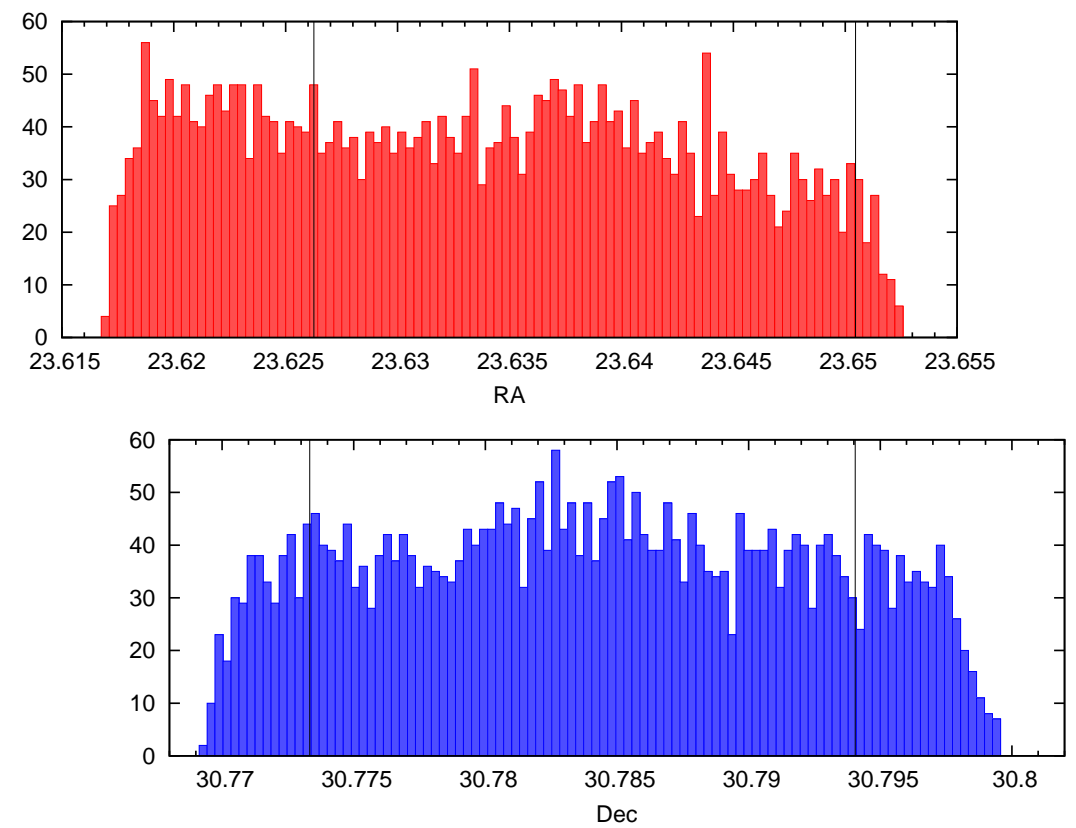

Figura 3.1: Histogramas del número de objetos por intervalo de ascención recta ( $R A$, en el panel superior) y declinación (Dec, en el panel inferior). Las líneas negras marcan el límite de la región definido mediante los contornos de Paß.

un determinado nivel de contorno de emisión de alguna de las líneas de recombinación del $\mathrm{H}$, el cual es ionizado por las estrellas masivas del cúmulo central (esto es conceptualmente similar a definir los límites como fue hecho en los estudios de Sandage \& Tammann (1974) e Israel \& van der Kruit (1974) antes mencionados). Como se describió en el Capítulo 2, las imágenes de banda angosta fueron adquiridas con los filtros $\mathrm{Pa} \beta, \mathrm{Br} \gamma$ y $\mathrm{H}_{2}$. En el rango espectral cubierto por los dos primeros se incluyen las líneas de recombinación del hidrógeno: $B r \gamma($ en $\lambda=2.17 \mu \mathrm{m})$ y $P a \beta($ en $\lambda=1.28 \mu \mathrm{m})$. Dichas líneas se originan durante la caída en cascada del electrón recapturado por el núcleo de $\mathrm{H}^{+}$, desde los niveles superiores de energía hasta el nivel fundamental. En el transcurso de la caída en cascada, el electrón puede pasar por los estados excitados $n=7 \rightarrow n=4$ ○ $n=5 \rightarrow n=3$, en cuyo caso se producen las líneas de $B r \gamma$ y $P a \beta$ respectivamente. La intensidad de la línea de $P a \beta$ es $\sim 6$ veces mayor que la de la línea de $B r \gamma$ dado que, para una nebulosa a $\mathrm{T} \sim 10000 \mathrm{~K}$ y densidades $\mathrm{n}_{e}=10^{2}$ $\mathrm{cm}^{-3}$, en el caso de recombinación $\mathrm{B}^{1}$, los cocientes teóricos de flujos son $j_{P a \beta} / j_{H \beta}=0.162$ y $j_{B r \gamma} / j_{H \beta}=0.0275$ (Osterbrock \& Ferland, 2006). Además de la intensidad teórica de las

\footnotetext{
${ }^{1} \mathrm{El}$ caso A de la teoría de líneas de recombinación asume que todos los fotones emitidos en la nebulosa escapan sin ser absorbidos, es decir, sin causar transiciones a niveles superiores. Este caso es una buena aproximación para nebulosas de muy baja densidad, ópticamente delgadas en todas las líneas de resonancia (serie de Lyman). El caso de recombinación B, es más adecuado para la mayoría de las nebulosas observables y considera que cada fotón de la serie de Lyman es absorbido varias veces y transformado ( $\operatorname{si~} \mathrm{n}$ ¿3) en fotones de series más bajas más un fotón Ly $\alpha$ o dos fotones de continuo (Osterbrock \& Ferland, 2006).
} 
líneas, otro efecto importante a considerar en el caso de las regiones de formación estelar, es el hecho de que las longitudes de onda más cortas se encuentran más afectadas por la absorción del polvo presente en el medio interestelar (el cociente de absorciones $A_{J} / A_{K}=0.282 / 0.112=2.52$ según Rieke \& Lebofsky, 1985). En el caso de zonas con mucha absorción este efecto resultaría significativo, pero para las regiones externas de NGC604, la absorción promedio del medio interestelar, fuera de los nudos de emisión nebular, es de $A_{V}=0.3 \mathrm{mag}\left(A_{K} \sim 0.034 \mathrm{mag}\right.$ ) según el estudio de Churchwell \& Goss (1999). Bajo estas consideraciones, se han utilizado los contornos de $\mathrm{Pa} \beta$ correspondientes a un nivel de $5 \sigma$ sobre la emisión de fondo para definir el límite de la región central.

En la Figura 3.2 se muestra la imagen de $P a \beta$, sobre la cual se ha graficado el contorno de $P a \beta$ a $5 \sigma$ sobre la emisión de fondo. Al contorno se le ha aplicado un suavizado mediante una convolución gaussiana de $\sigma_{\text {conv }}=5$ pix. Teniendo en cuenta este contorno, se definió la región central como el área interior del círculo que lo contiene.

Ya se ha mencionado en el Capítulo 2 que el campo de las imágenes de Gemini-NIRI abarca un área cuadrada de $\sim 120^{\prime \prime} \times 120^{\prime \prime}\left(1024 \times 1024\right.$ pix $^{2}$ de $0.117^{\prime \prime}$ pix $\left.^{-1}\right)$ de los cuales, debido al patrón de dithering (85 pix) y a que no se consideran los objetos ubicados muy cerca del borde de las imágenes, el área efectiva del campo con objetos que tienen fotometría PSF confiable es de $\sim 105^{\prime \prime} \times 105^{\prime \prime}\left(898 \times 898\right.$ pix $\left.^{2}\right)$, la cual equivale a un área de $430 \times 430$ pc $^{2}$. Así definida, el área de la región central está centrada en $\alpha=01^{h} 34^{m} 33^{s} .14$ y $\delta=+30^{\circ} 47^{\prime} 1^{\prime \prime} .9$, tiene un radio de 309 pix ( 150 pc), y abarca un área de $69000 \mathrm{pc}^{2}$. La región de campo está constituída por el área de la imagen exterior al círculo y abarca una superficie de $117000 \mathrm{pc}^{2}$. El factor de escala entre las superficies de ambas regiones es $\sim 0.59$.

\subsection{Sobre el error interno de la fotometría}

La tarea utilizada para realizar el ajuste de PSF, DAOPHOT-ALLSTAR, realiza también un cálculo del error de las magnitudes medidas, según lo detallado en el Capítulo 2. Una forma de realizar un análisis que permita evaluar cuán confiable es el error calculado para la fotometría, consiste en agregar en las imágenes estrellas ficticias cuyas 'magnitudes verdaderas' son conocidas (ya que son las magnitudes asignadas). Las magnitudes de las estrellas ficticias se miden siguiendo exactamente el mismo procedimiento realizado para medir las magnitudes de las estrellas reales del campo (de hecho se vuelve a medir la fotometría sobre todas las estrellas, reales más ficticias, de la imagen). Las magnitudes medidas para las estrellas ficticias se comparan con las 'magnitudes verdaderas' de dichas estrellas y se obtiene la relación entre el error calculado y el 'error verdadero', es decir, el valor absoluto de la diferencia entre la 'magnitud verdadera' y la 'magnitud calculada' de la fotometría, $\operatorname{err}_{v}=\left|\operatorname{mag}_{V}-\operatorname{mag}_{P S F}\right|$.

Las principales fuentes de error de la fotometría de acuerdo a las características físicas de la región central son: 


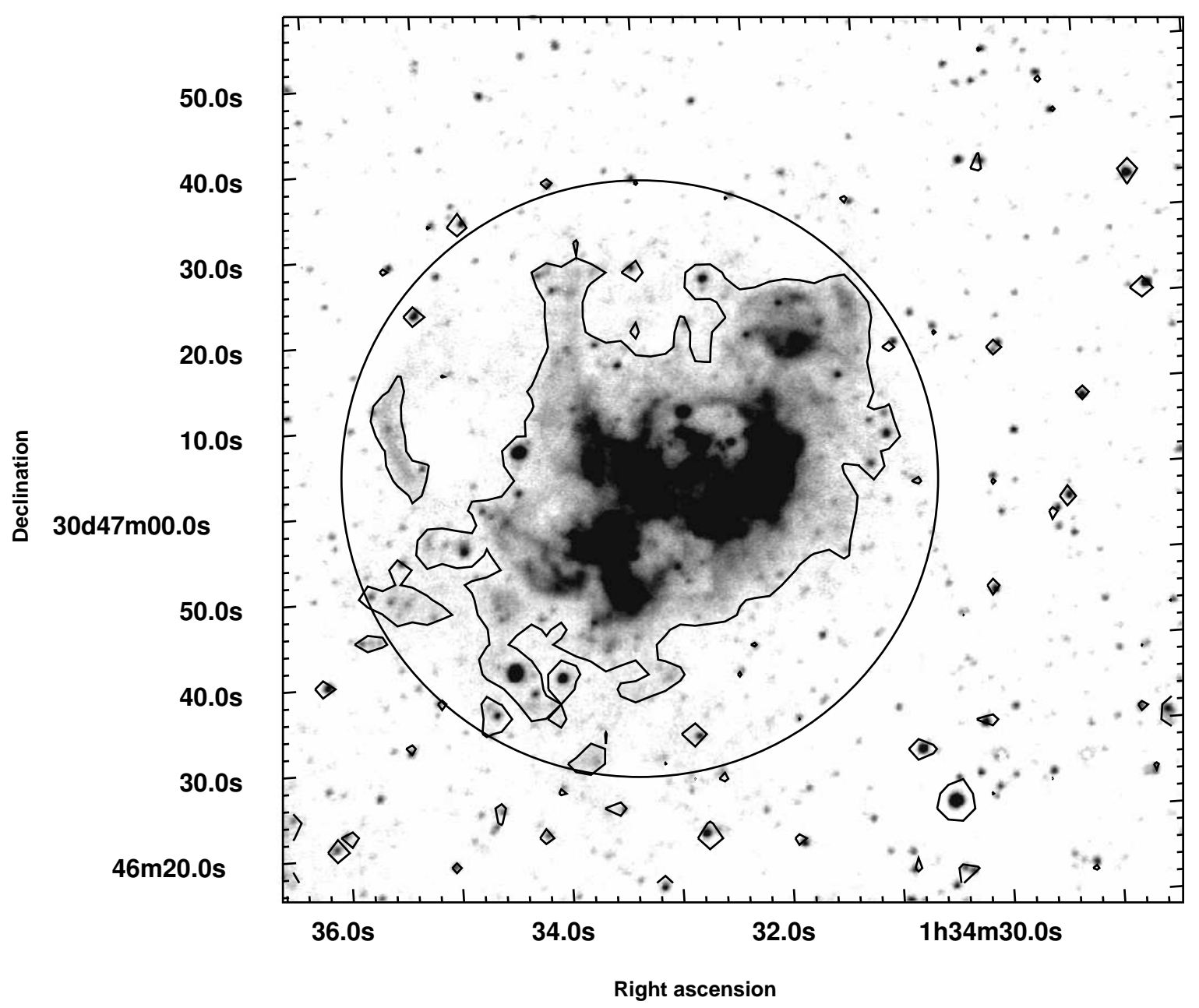

Figura 3.2: Imagen de Paß, sobre la cual se ha graficado el contorno de Paß a $5 \sigma$ sobre la emisión de fondo. Al contorno se le ha aplicado un suavizado mediante una convolución gaussiana de $\sigma_{\text {conv }}=5$ pix. Teniendo en cuenta este contorno, se definió la región central de NGC 604 como el área interior del círculo que lo contiene. 
1. Errores producidos por el brillo observado de los objetos: en el campo de NGC 604 hay objetos que abarcan un amplio rango de brillos; los objetos muy débiles (cercanos al límite de detección) o demasiado brillantes (cercanos a límite de saturación del detector) presentan errores mayores. Los objetos que superan el límite de saturación no fueron incluidos en la fotometría.

2. Errores producidos por poco contraste entre los objetos y la emisión nebular del medio: en las regiones donde la emisión nebular es muy alta las fuentes puntuales presentan menor contraste contra el fondo de emisión nebular; a este efecto se le suma que, en general, la emisión nebular es variable en escalas espaciales pequeñas y obtener un valor adecuado para las cuentas de cielo del objeto presenta mayor dificultad en estas regiones. Por otro lado, al ser una región de formación estelar, una gran cantidad de fuentes están rodeadas por su propia emisión nebular.

3. Errores producidos por la alta densidad objetos en una determinada región de la imagen ('crowding'): como sucede en la parte central del cúmulo de NGC 604.

Debido a que la región central y la región de campo presentan características de imagen diferentes en cuanto a nebulosidad y población estelar, se han considerado separadamente en el estudio de los errores de la fotometría, a fin de poder analizar cada una de las fuentes de error previamente mencionadas.

Para cada una de las dos regiones, se analizó la función de luminosidad en las bandas, es decir se dividió el intervalo [magnitud mínima:magnitud máxima] en subintervalos de 0.5 magnitudes y se generó un histograma del número de estrellas por intervalo de magnitud. Para cada banda se creó una nueva imagen con estrellas artificiales utilizando la tarea ADDSTAR. En dichas imágenes se agregó un número de estrellas artificiales equivalente al $10 \%$ del número de estrellas reales en cada intervalo de magnitud, en cada región. Las estrellas ficticias fueron creadas usando el modelo de PSF generado para cada banda, con el fin de que se asemejen, lo máximo posible, a los objetos reales observados. La posición de las estrellas ficticias agregadas fue generada al azar por la tarea ADDSTAR. En la Figura 3.3 se muestra una imagen en la banda $J$, en la cual se han marcado las estrellas artificiales agregadas en la región central (círculos rojos) y en la región de campo (círculos azules).

En la Figura 3.4 se muestran tres diagramas donde se ha graficado la diferencia entre el valor de la 'magnitud verdadera' y la 'magnitud medida' $\left(\operatorname{mag}_{V}-\operatorname{mag}_{P S F}\right)$, en función de la 'magnitud verdadera' para cada una de las estrellas artificiales agregadas y medidas en las imágenes de bandas $J$ (panel superior), $H$ (panel medio) y $K s$ (panel inferior). Las barras de error representan el error de la magnitud calculado por DAOPHOT-ALLSTAR en la fotometría PSF. Los símbolos rojos corresponden a las estrellas ficticias agregadas en la región central y los azules a las agregadas en la región de campo. Como es de esperar, si se considera que el error calculado por DAOPHOT-ALLSTAR no presenta ningún sesgo, los valores de $\left(\operatorname{mag}_{V}-\operatorname{mag}_{P S F}\right)$, a nivel global, se encuentran distribuidos alrededor de cero y, para la mayoría de los objetos se cumple que $\left(\operatorname{mag}_{V}-\operatorname{mag}_{P S F}\right)<\operatorname{err}\left(\operatorname{mag}_{P S F}\right)$. Se advierte, lógicamente, que la dispersión de los puntos 


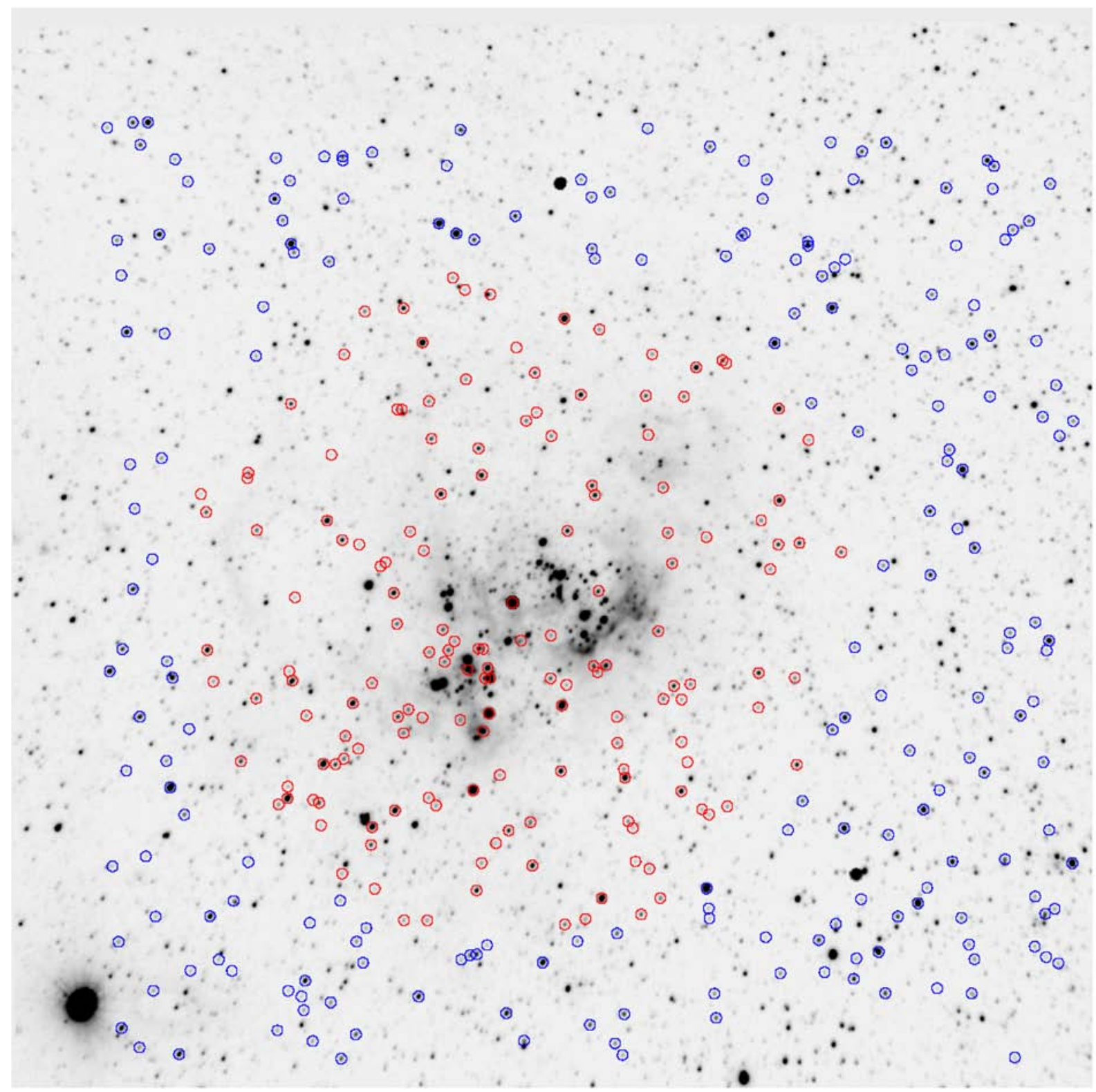

Figura 3.3: Imagen de la banda $J$ sobre la cual se han marcado las estrellas ficticias agregadas con la tarea ADDSTAR, en la región central (círculos rojos) y en la región de campo (círculos azules). 
crece hacia las magnitudes más débiles. Vale aclarar que si bien en estos gráficos se ha incluido todo el rango de magnitudes medidas, los objetos que finalmente serán considerados en este estudio son aquellos con magnitudes menores que 21.5 para la banda $J$ y menores que 20.5 para las bandas $H$ y $K s$ (estos límites fueron derivados del análisis de completitud que será descripto en la próxima Sección). En los diagramas de la Figura 3.4 también se evidencian las otras dos fuentes de error señaladas previamente cuando se comparan los resultados obtenidos para las magnitudes medidas en ambas regiones: en general, los valores de $\left(\operatorname{mag}_{V}-\operatorname{mag}_{P S F}\right)$ de las estrellas ficticias agregadas en la región central presentan mayor dispersión que el de los objetos agregados en la región de campo; esto se debe al alto nivel de 'crowding' y a la emisión nebular (intensa y variable) de la región central.

\subsection{Sobre la completitud de la fotometría}

Las funciones de luminosidad para cada banda generadas en el análisis del error interno de la fotometría explicado en la Sección precedente, contienen también información respecto del límite superior de las magnitudes medidas, es decir, los objetos más débiles medidos y, en consecuencia, sobre la completitud de la fotometría. En la Figura 3.5 se muestran los histogramas que representan la función de brillo para las bandas $J, H$ y $K s$ correspondientes a todo el campo de NGC 604 (región central + región de campo), en los tres paneles superiores; a la región central, en los tres paneles de la segunda fila y a la región de campo, en los tres paneles de la tercer fila; los tres paneles inferiores corresponden a la diferencia (región central-región de campo), realizada por intervalo de magnitud, de los histogramas correspondientes la región central y a la región de campo (previo a realizar la resta, el número de objetos de la región de campo fue multiplicado por el factor de escalas entre las áreas de las dos regiones, 0.59). Es importante tener en cuenta que, como se explicó en el Capítulo 2, la lista inicial de objetos a medir fue generada corriendo la tarea DAOFIND sobre una imagen $(J+K s)$, suma de la imagen final de la banda $J$ más la imagen final de la banda $K s$, por este motivo, los histogramas mostrados en la Figura 3.5 contienen información significativa respecto a los objetos 'medidos' en cada banda pero no respecto de los objetos 'detectados' en cada banda (ya que la lista original de objetos fue una única lista y no se generó haciendo una búsqueda de objetos independiente para cada uno de los filtros).

Según la función de distribución de masas estelares, el número de objetos debe ir en aumento conforme el brillo disminuye; el hecho de que en los histogramas comience a disminuir en número de objetos a partir de una determinada magnitud es un efecto observacional; con determinada configuración instrumental no se pueden detectar/medir los objetos con magnitudes mayores a un determinado valor. Teniendo en cuenta este efecto, suele adoptarse el criterio que establece que la fotometría es 'completa' hasta la magnitud correspondiente al intervalo anterior al que contiene el mayor número de objetos. En los datos aquí presentados, observando los histogramas de la Figura 3.5, se concluye que dichas magnitudes corresponden a $\mathrm{J}=21.5$, 

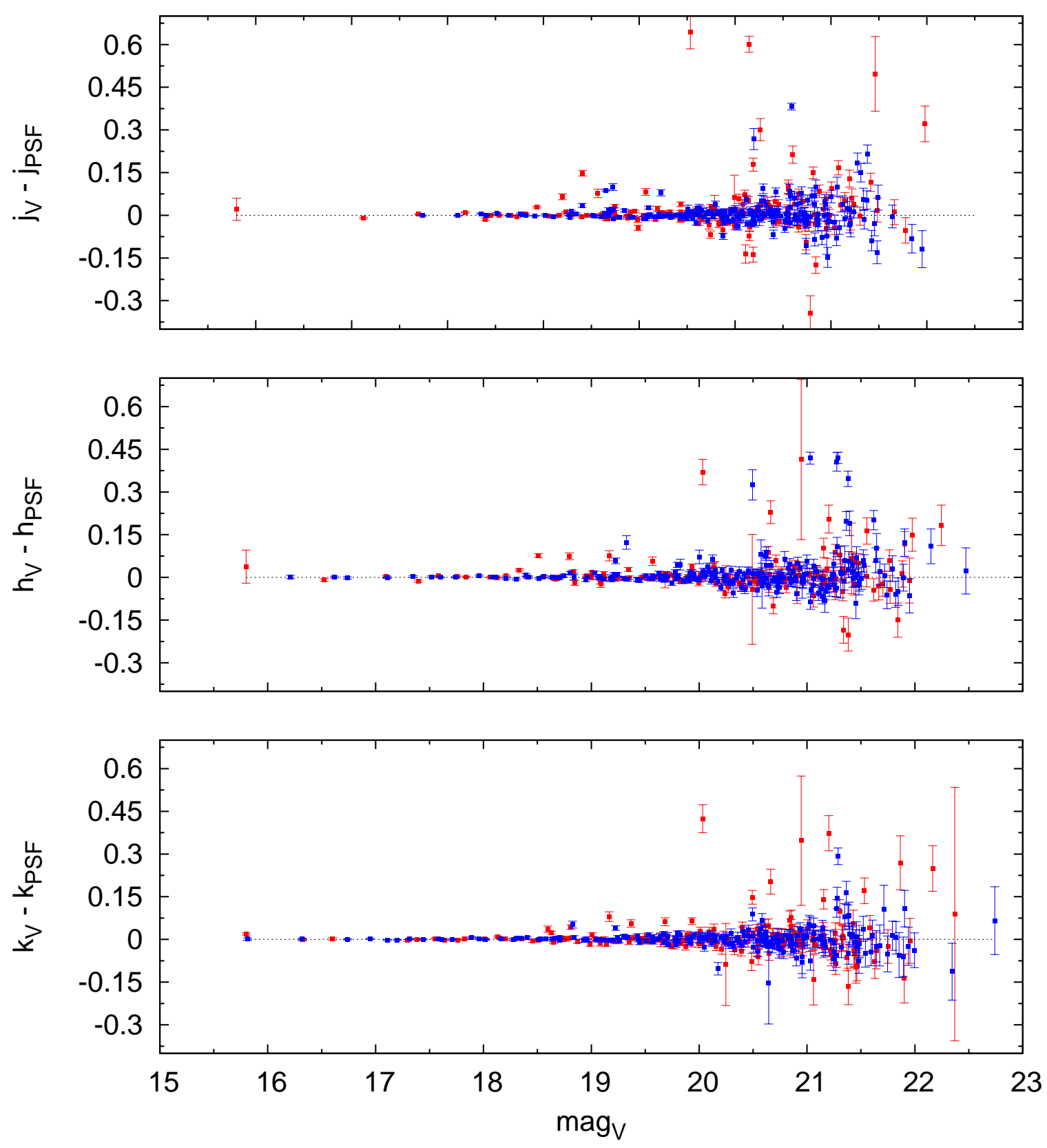

Figura 3.4: Diagramas de la diferencia entre el valor de la 'magnitud verdadera' y la 'magnitud medida' $\left(\operatorname{mag}_{V}-\operatorname{mag}_{P S F}\right)$, en función de la 'magnitud verdadera' para cada una de las estrellas artificiales agregadas y medidas en las imágenes de bandas $J$ (panel superior), $H$ (panel medio) y Ks (panel inferior). Las barras de error representan el error de la magnitud calculado por DAOPHOT-ALLSTAR en la fotometría PSF. Los símbolos rojos corresponden a las estrellas ficticias agregadas en la región central y los azules a las agregadas en la región de campo. 

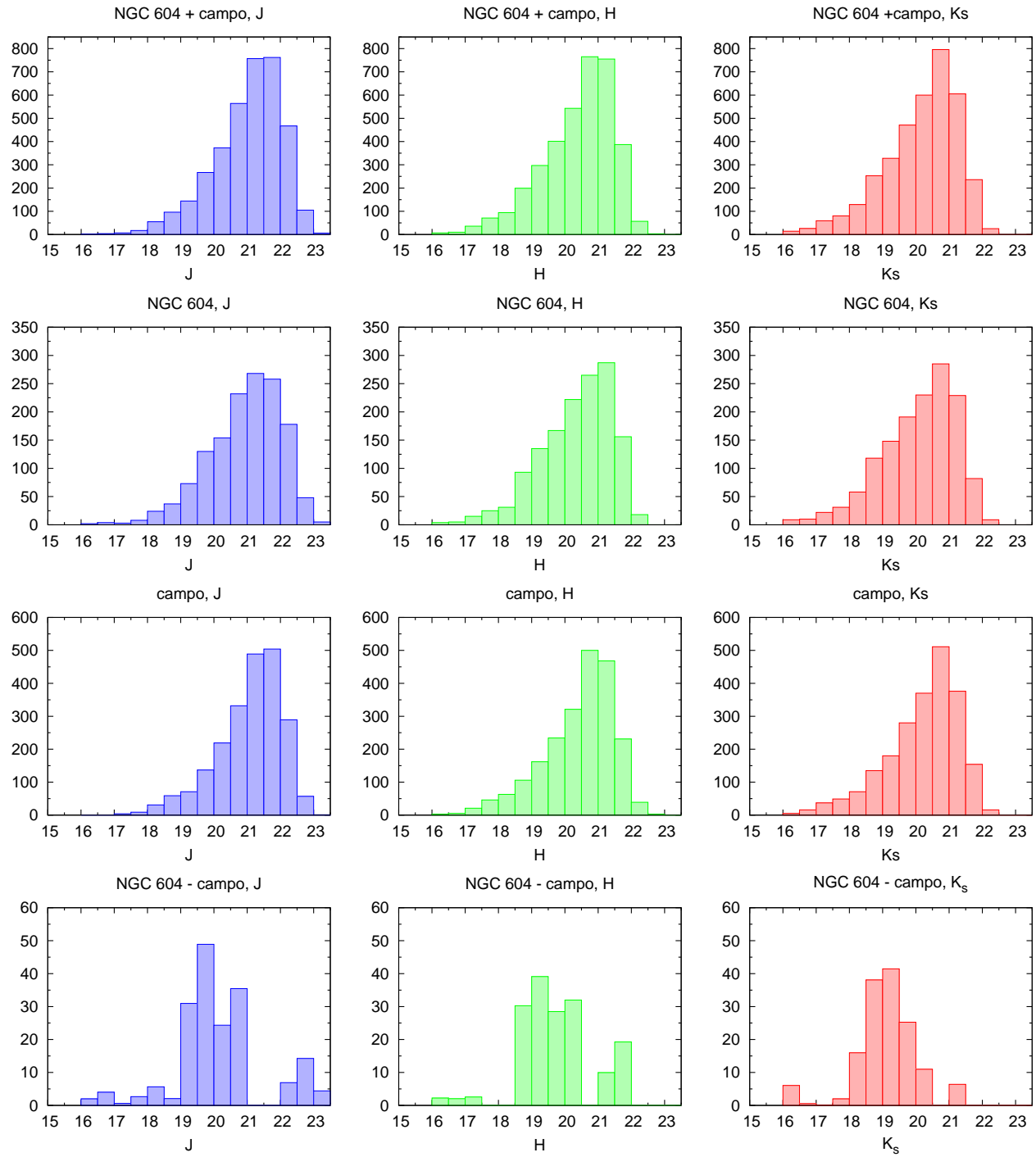

Figura 3.5: Histogramas que representan la función de brillo para las bandas $J, H$ y Ks correspondientes a todo el campo de NGC604 (región central + región de campo), en los tres paneles superiores; a la región central, en los tres paneles de la segunda fila y a la región de campo, en los tres paneles de la tercer fila; los tres paneles inferiores corresponden a la diferencia (región central-región de campo), realizada por intervalo de magnitud, de los histogramas correspondientes la región central y a la región de campo (previo a realizar la resta, el número de objetos de la región de campo fue multiplicado por el factor de escalas entre las áreas de las dos regiones, $0.59)$. 


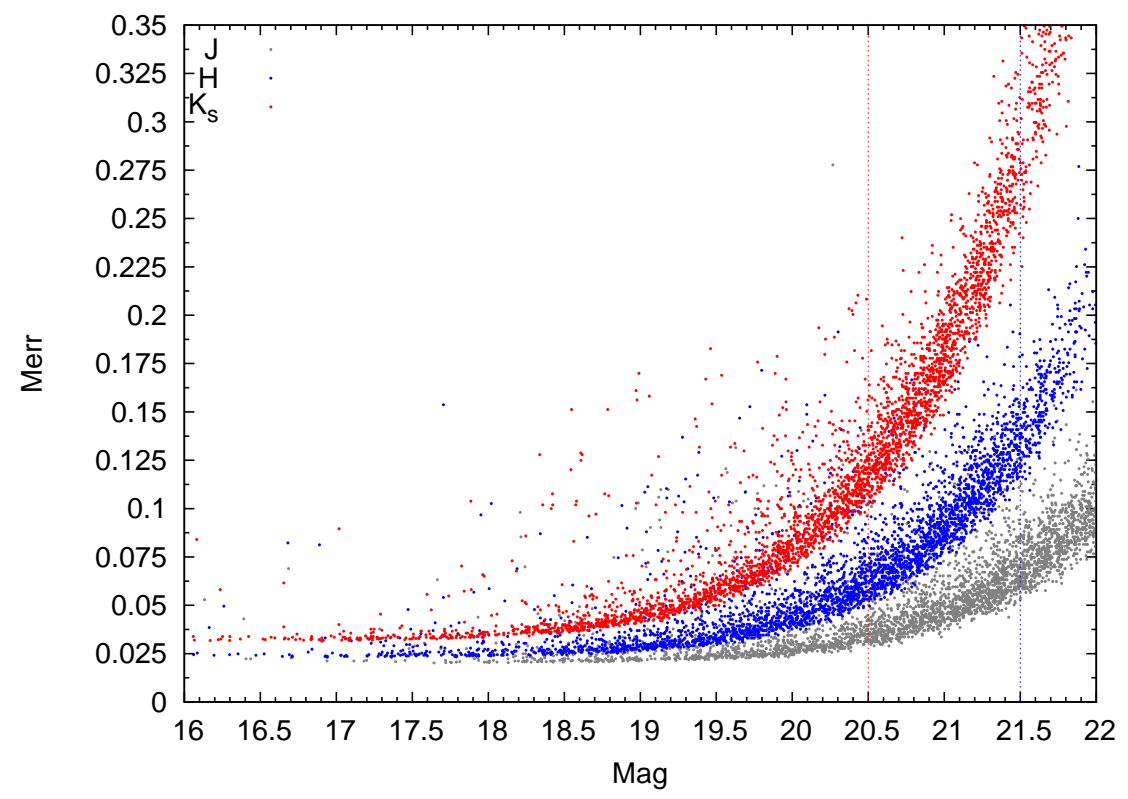

Figura 3.6: Distribución de las incertezas de las magnitudes derivadas por ALLSTAR en función de las magnitudes para los objetos en las tres bandas. La línea vertical roja corresponde al valor límite en las magnitudes para las bandas $H$ y Ks y la línea vertical azul al de la banda J.

$\mathrm{H}=20.5$ y $\mathrm{Ks}=20.5$. Limitar las magnitudes a estos valores máximos impone implícitamente un límite en las incertezas de la fotometría. La Figura 3.6 muestra la distribución de incertezas de las magnitudes derivadas por ALLSTAR en función de las magnitudes para los objetos en las tres bandas. La línea vertical roja corresponde al valor límite en las magnitudes para las bandas $H$ y $K s$ y la línea vertical azul al de la banda $J$.

En adelante, para los análisis globales presentados en esta Tesis se considerarán sólo los objetos con $\mathrm{J}<21.5, \mathrm{H}<20.5$ y $\mathrm{Ks}<20.5$, a menos que específicamente se indique otra cosa.

Un último comentario relativo a la Figura 3.5 es que los 3 paneles inferiores, que corresponden a la resta, por intervalo de magnitud, entre los objetos de la región central menos la región de campo, se evidencia la sobredensidad de fuentes de la región central producida, naturalmente por los objetos pertenecientes a la SOBA de NGC 604. Por otro lado, puede observarse que la distribución de los histogramas de la resta se va desplazando levemente hacia valores de magnitudes menores en las bandas $J, H$ y $K s$, efecto que se evidenciará en el diagrama CC presentado en la siguiente Sección.

\subsection{Diagramas color-color y color-magnitud}

Las Figuras 3.7 y 3.8 contienen los resultados fundamentales del estudio realizado en esta Tesis. Dichas figuras muestran los diagramas color-color (CC) y color-magnitud (CM) respecti- 
vamente, generados con 692 objetos pertenecientes a la región central, cuyas magnitudes fueron medidas en las tres bandas y cumplen con $\mathrm{J}<21.5, \mathrm{H}<20.5$ y $\mathrm{Ks}<20.5$. En ambos diagramas se graficaron como referencia, la ubicación teórica de las estrellas de secuencia principal $\left(\mathrm{MS}^{2}\right)$ y de las gigantes (indicadas con 'V' y 'III', respectivamente), la ubicación de ambas secuencias corresponde a objetos no afectados por extinción y los valores fueron tomados de Tokunaga (2000). Los vectores de extinción (graficados con un segmento rosa en ambos diagramas) corresponden a una absorción de $A_{V}=10.0 \mathrm{mag}$ y se han generado utilizando los valores de extinción derivados por Rieke \& Lebofsky (1985). En el diagrama CM también se ha incluido la ubicación teórica de las estrellas supergigantes y la correspondiente a las estrellas de secuencia principal de edad cero (ZAMS), indicadas con las letras 'l' y ' $z$ ' respectivamente. Las magnitudes para las estrellas OV en el diagrama CM fueron extraídas de Martins \& Plez (2006), las correspondientes a las estrellas de ZAMS fueron extraídas de Hanson et al. (1997) y las magnitudes $\mathrm{K}$ de las estrellas supergigantes se calcularon usando el color $(V-K)$ de Tokunaga (2000) junto con las magnitudes en la banda V publicadas por Wegner (2007). Las magnitudes observadas de los objetos de la fotometría fueron transformadas a magnitudes absolutas usando el módulo de distancia correspondiente a $M 33\left(m_{V}-M_{V}=24.62\right)$. Finalmente, en este diagrama se han incluido, como referencia, dos objetos masivos jóvenes, pertenecientes a la Vía Láctea, previamente estudiados: S106 IRS24, una protoestrella clasificada como objeto de Clase 0 (Furuya et al., 1999) y la fuente NGC 2024 IRS2, que fue originalmente identificada como una región UCHII, pero en el estudio realizado por Bik et al. (2003), se ha sugerido que este objeto debe ser una estrella joven de gran masa rodeada por un disco que contiene polvo. Dado que las escalas de tiempo que rigen la formación y evolución de las estrellas masivas son extremadamente cortas (de pocos millones de años), 'una estrella joven masiva' es un objeto que se encuentra ligado a episodios de formación estelar reciente.

En la Figura 3.7, diagrama CC, pueden distinguirse varios grupos de objetos:

- Alrededor de $(H-K s) \sim 0.15$ y $(J-H) \sim 0.8$, hay un grupo numeroso de objetos constituido principalmente por estrellas de MS con extinción y estrellas evolucionadas en la fase de gigantes. Este grupo de objetos se extiende siguiendo los vectores de extinción hacia valores mayores de $(H-K s)$ y $(J-H)$ al encontrarse afectados por la absorción creciente del medio interestelar.

- Alrededor de $(H-K s) \sim 0.0$ y $(J-H) \sim 0.0$, se encuentra un grupo, no muy numeroso, de estrellas masivas de MS con poca extinción.

- Hacia la derecha del vector de extinción correspondiente a una estrella tipo O6-8 V, hay un grupo importante de objetos que presentan exceso infrarrojo (exceso IR), es decir, objetos cuya magnitud en la banda $K s$ es más brillante que lo que cabe esperar para un

\footnotetext{
2MS: del acrónimo en inglés de 'Main Sequence' (secuencia principal).
} 
objeto estelar tanto de la secuencia principal como evolucionado. El exceso IR se mide como la distancia a la línea de extinción correspondiente a una estrella 06-08 V. Cabe aclarar que dicho exceso IR no es consecuencia de la extinción producida por el polvo del medio interestelar (en cuyo caso, los objetos se desplazan a lo largo de la dirección de los vectores de extinción), sino que es causado por material, gas y polvo, a alta temperatura, ubicado en los alrededores inmediatos de una fuente central. Es decir que el desplazamiento de los objetos en el diagrama CC, hacia valores de (H-Ks) altos, es producido por un fenómeno 'circumestelar' y no interestelar (Stahler \& Palla, 2004). Como se mencionó en el Capítulo 1, en regiones de formación estelar masiva como NGC 604, estos objetos con exceso IR pueden estar principalmente relacionados con objetos masivos jóvenes (MYSOs) probablemente todavía en el proceso de formación, y en menor número con objetos evolucionados como estrellas supergigantes $\mathrm{B}$ [e] y tipo Of (con líneas de emisión) y estrellas WR. También en el Capítulo 1 se ha hecho referencia a que las estrellas tipo WR y los objetos más evolucionados en la región ya han sido estudiados por varios autores. El estudio fotométrico de esta Tesis se focaliza en la población masiva más joven de NGC 604, es decir en los objetos candidatos a MYSOs, los cuales se describirán y analizarán más detalladamente en las próximas Secciones.

Tanto en el diagrama CC como en el CM, los objetos con exceso IR se han discriminado en cuatro grupos de acuerdo a la 'medida' del exceso IR que presentan:

1. Los cuadrados rojos representan objetos con exceso IR extremo (exclR $\mathrm{R}_{3}$ ), para estos objetos el exceso IR es al menos tres veces mayor que su incerteza en ( $H-K s)$, es decir: exclR $3>3 \times \operatorname{err}(H-K s)$

2. Los círculos azules corresponden a los objetos con un exceso IR importante pero no extremo $($ exclR 2$)$, para los cuales se cumple que:

$2 \times \operatorname{err}(H-K s)<\operatorname{exclR} 2 \leq 3 \times \operatorname{err}(H-K s)$

3. Los círculos verdes (exclR $)_{1}$ cumplen con:

$1 \times \operatorname{err}(H-K s)<\operatorname{exclR} 1 \leq 2 \times \operatorname{err}(H-K s)$

4. Los triángulos negros presentan exceso IR (exclR $)_{0}$ dentro de sus incertezas en el color $(H-K s)$, de modo que:

$\operatorname{exclR} R_{0} \leq 1 \times \operatorname{err}(H-K s)$

La incerteza en los colores fue calculada mediante la propagación canónica de errores: $\operatorname{err}\left(H-K_{s}\right)=\sqrt{\operatorname{err}(H)^{2}+\operatorname{err}\left(K_{s}\right)^{2}}$ y $\operatorname{err}(J-H)=\sqrt{\operatorname{err}(J)^{2}+\operatorname{err}(H)^{2}}$.

En general, como es de esperarse, las barras de error de los objetos con exceso IR suelen ser mayores que las de los objetos que presentan colores estándares en el mismo rango de magnitudes. 
En adelante, cuando se haga referencia a los objetos que presentan exceso $I R$, se considerarán los objetos pertenecientes a los grupos exclR $R_{1}$, exclR $R_{2}$ y exclR $R_{3}$ indistintamente, a menos que se indique otra cosa. Los objetos con exclR $\mathrm{R}_{0}$ no serán considerados como objetos con exceso IR ya que la incerteza en su color $(H-K s)$ podría situarlos en la posición de 'objetos normales'.

En la Figura 3.9 se han incluido, a modo ilustrativo, los diagramas CC (panel superior) y CM (panel inferior) de los objetos pertenecientes a la región de campo. Al comparar estos diagramas con los de la región central, es evidente que la región de campo posee menos objetos con exceso IR, más aun considerando que los objetos incluidos en estos diagramas corresponden a la región de campo total cuya área es un factor $\sim 1.7$ más grande que la región central. Una comparación más precisa entre los diagramas CC de ambas regiones se realizará en la siguiente Sección al considerar la contaminación por objetos de campo.

\subsection{Contaminación por objetos de campo}

Antes de continuar con el análisis derivado de los diagramas CC y CM es necesario estudiar cuál es la contribución de los objetos de campo en dichos diagramas.

Con la expresión 'objetos de campo' se hace referencia a los objetos que no están físicamente vinculados a NGC 604 pero que, en proyección, se encuentran dentro del campo de la región de estudio. Los objetos de campo pueden estar ubicados en la línea de la visual por delante de NGC 604 o bien, pueden estar más alejados, ubicados por detrás de NGC604 (en ciertas oportunidades se hará referencia a estos objetos como objetos de 'foreground' y 'background' respectivamente, ya que es la forma en que se los denomina comúnmente en la literatura). Los objetos de campo de foreground pueden ser objetos estelares pertenecientes tanto a la Vía Láctea como a M33, los de objetos de background pueden ser fuentes estelares de M 33 y objetos no estelares más distantes como galaxias y quasares.

Con el fin de estimar la contaminación por objetos pertenecientes a la Vía Láctea se utilizó el modelo de síntesis de población estelar galáctica de Besancon ${ }^{3}$. Se realizó una simulación para el campo observado la cual dió como resultado que la contaminación de estrellas de la Vía Láctea en el área observada es sólo de 6 objetos: son estrellas de secuencia principal entre las cuales dominan las de tipo $F$, pertenecen a la población de disco de la galaxia y todas se encuentran ubicadas a una distancia menor a $3 \mathrm{kpc}$.

Para el estudio de esta Tesis es principalmente importante examinar, con detalle, la contaminación de los objetos de campo que puedan ubicarse en las mismas regiones de los diagramas CC y CM ocupadas por los MYSOs, lo cual podría generar identificaciones erróneas de MYSOs

\footnotetext{
${ }^{3} h t t p: / /$ model.obs - besancon.fr/
} 


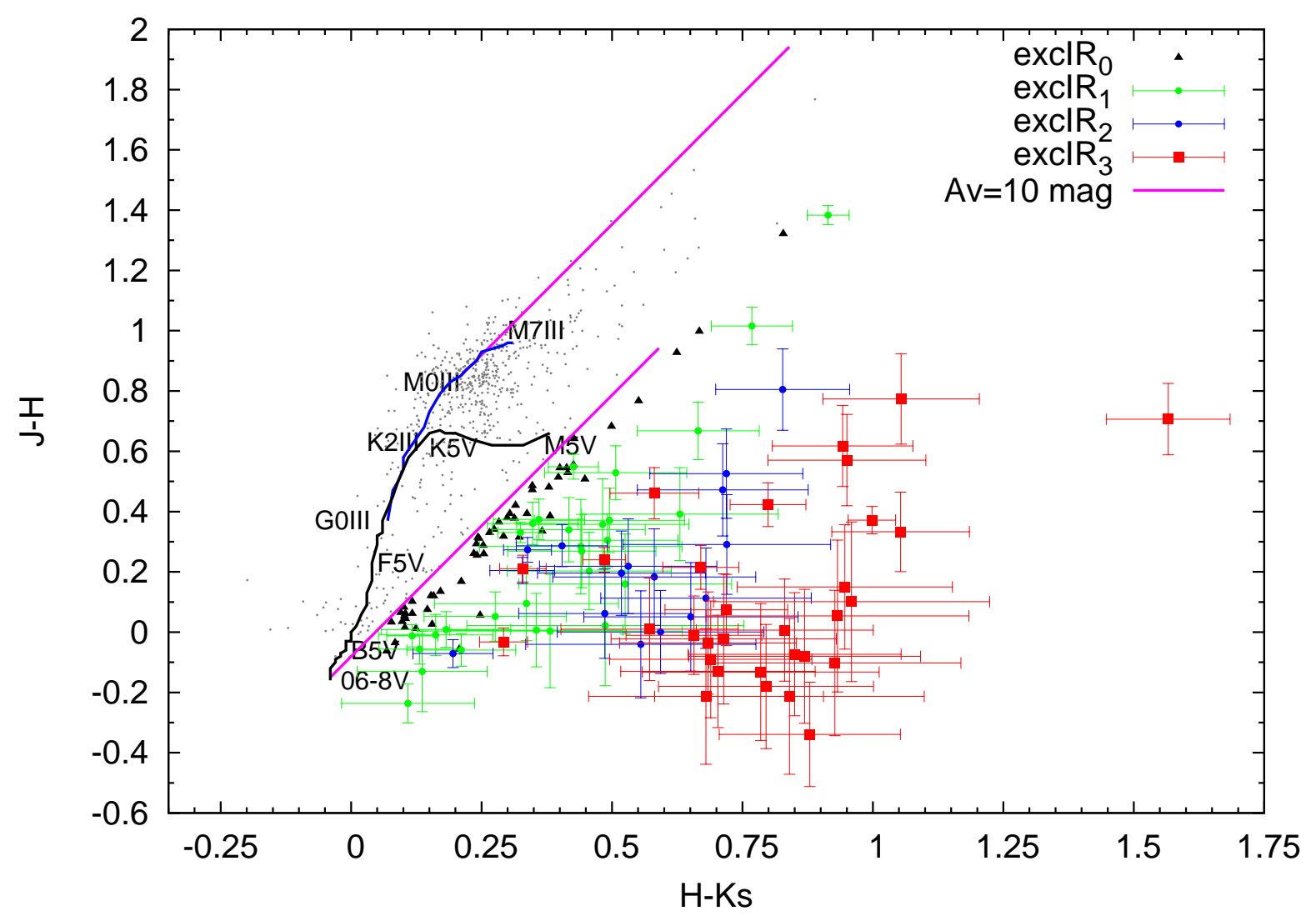

Figura 3.7: Diagrama color-color generado con 692 objetos pertenecientes a la región central, con $J<21.5, H<20.5$ y $\mathrm{Ks}<20.5$. Se graficaron como referencia, la ubicación teórica de las estrellas de MS y de las gigantes (indicadas con ' $V$ ' y 'III', respectivamente). Los vectores de extinción (segmentos rosa) corresponden a una absorción de $A_{V}=10.0 \mathrm{mag}$. Los objetos con exceso IR se han discriminado en cuatro grupos de acuerdo a la 'medida' del exceso que presentan: I) Cuadrados rojos: objetos con exceso IR extremo, excIR $R_{3}>3 \times \operatorname{err}(H-K s)$. II) Círculos azules: objetos con un exceso IR importante pero no extremo, $2 \times \operatorname{err}(H-K s)<\operatorname{excIR} 2 \leq 3 \times \operatorname{err}(H-K s)$.

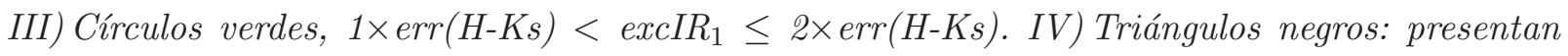
exceso IR dentro de sus incertezas en el color (H-Ks), excIR $R_{0} \leq 1 \times \operatorname{err}(H-K s)$. 


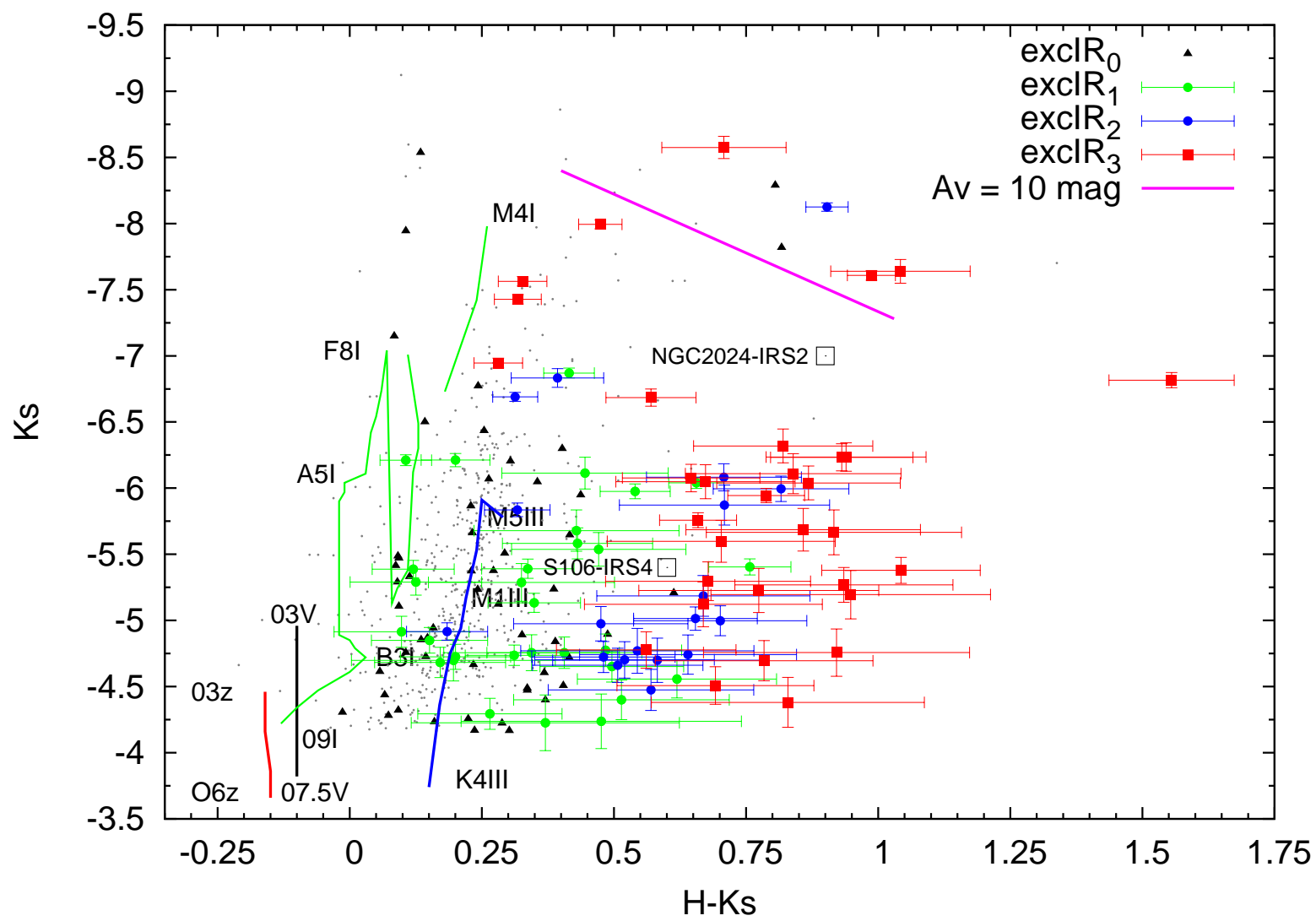

Figura 3.8: Diagrama color-magnitud generado con 692 objetos pertenecientes a la región central, con $J<21.5, H<20.5$ y Ks <20.5. Se graficaron como referencia, la ubicación teórica de las estrellas de ZAMS, MS, gigantes y supergigantes (indicadas con ' $z$ ', 'V', 'III' y 'I', respectivamente). El vector de extinción (segmento rosa) corresponde a una absorción de $A_{V}=10.0$ mag. Los objetos con exceso IR se han discriminado en cuatro grupos de acuerdo a la 'medida' del exceso que presentan: I) Cuadrados rojos: objetos con exceso IR extremo, excIR $R_{3}>3 \times \operatorname{err}(H-K s)$. II) Círculos azules: objetos con un exceso IR importante pero no extremo, $2 \times \operatorname{err}(H-K s)<\operatorname{excIR_{2}} \leq 3 \times \operatorname{err}(H-$

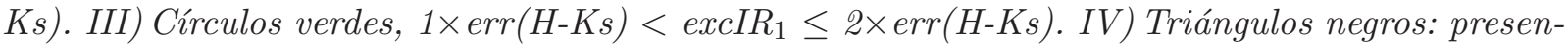
tan exceso IR dentro de sus incertezas en el color $(H-K s)$, excIR $R_{0} \leq 1 \times \operatorname{err}(H-K s)$. También se han incluido, como referencia, dos objetos galácticos bien conocidos: S106 IRS24, una protoestrella clasificada como objeto de Clase 0 y NGC 2024 IRS2, una estrella joven y masiva con un disco de polvo a su alrededor. Las magnitudes observadas de los objetos de la fotometría fueron transformadas a magnitudes absolutas usando el módulo de distancia correspondiente a M 33 $\left(m_{V}-M_{V}=24.62\right)$. 

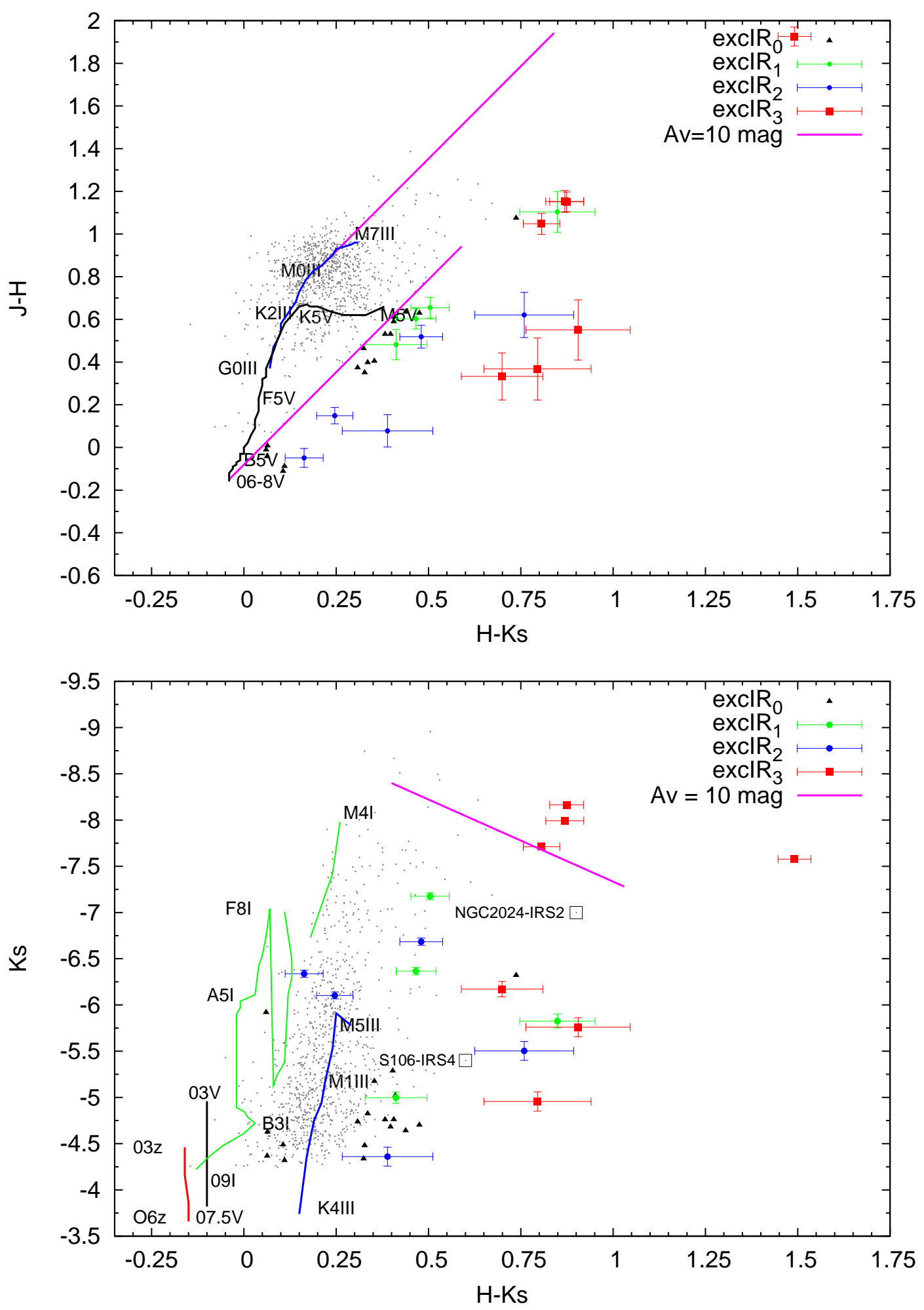

Figura 3.9: Diagramas color-color (panel superior) y color-magnitud (panel inferior) de los objetos pertenecientes a la región de campo. 
y, en consecuencia, una sobrestimación de su número. Si bien se espera que la contaminación por objetos de campo no sea dominante ${ }^{4}$, es necesario examinar la presencia y ubicación de los objetos de campo, particularmente en el diagrama CC. Con este fin se generaron, separadamente, los diagramas CC correspondientes a los objetos de la región central y de la región de campo definidas en las Secciones precedentes. Obviamente, ambos diagramas incluyen objetos de campo (no pertenecientes a NGC 604) y resulta imposible discriminarlos fehacientemente si sólo se cuenta con datos fotométricos. Sin embargo, los diagramas generados por separado permiten obtener una idea de la distribución global de los objetos pertenecientes a ambas regiones y, con dicha información, se puede realizar una resta estadística de los objetos de campo presentes en el diagrama de los objetos de la región central. La resta no se realiza sobre objetos individuales sino sobre el número de objetos por secciones cuadradas del diagrama CC, según se explica a continuación.

Dado que la región central y la región de campo tienen distinta superficie y que se desea realizar una resta estadística de objetos, los diagramas CC se han generado como diagramas de densidad (también llamados 'diagramas de Hesse'). Dichos diagramas son, conceptualmente, histogramas en dos dimensiones, para los cuales se han considerado intervalos (cuadrados) de 0.05 mag en $(H-K s)$ y $(J-H)$. En la Figura 3.10 se muestran tres diagramas CC generados como diagramas de densidad; el panel superior corresponde al diagrama CC de los objetos ubicados en la región central (este diagrama incluye objetos propios de NGC $604+$ objetos de campo), el panel central corresponde al diagrama de los objetos ubicados en la región de campo (al número de objetos de cada intervalo de este histograma se lo multiplicó por el factor 0.59 que es la relación de escala entre las áreas de las regiones consideradas). Finalmente, en el panel inferior se muestra la resta estadística de objetos de ambos diagramas, (región central-región de campo). Esta resta fue aplicada al número de objetos de cada diagrama, en secciones cuadradas de $0.05 \mathrm{mag} \times 0.05 \mathrm{mag}$. La escala de colores utilizada en los diagramas indica el número de objetos en cada intervalo según la referencia ubicada en el margen derecho de cada diagrama.

En la Figura 3.10 tres diferencias fundamentales entre la distribución de objetos en la región central y el campo de control resultan evidentes al comparar sus respectivos diagramas CC, y quedan claramente expuestas en el panel inferior correspondiente a la resta de los diagramas CC de ambas regiones.

1. El diagrama correspondiente a la región de campo (panel del medio) prácticamente no presenta objetos hacia valores de $(H-K s)>0.25$, que es la zona del diagrama ocupada por fuentes con exceso IR, mientras que, para región central (panel superior) la distribución de objetos se extiende ostensiblemente hacia la derecha, poblando la región de objetos

\footnotetext{
${ }^{4}$ En el Capítulo 1 se mencionó el hecho de que NGC 604 se encuentra en una posición muy favorable desde el punto de vista observacional: su dirección está fuera del plano de la Vía Láctea (long=133‥75590, lat $\left.=-31^{\circ} .17901\right)$ y se encuentra ubicada en la periferia de M 33, galaxia a la cual se la observa casi de frente, con un ángulo de inclinación $\mathrm{i}=57^{\circ}$.
} 

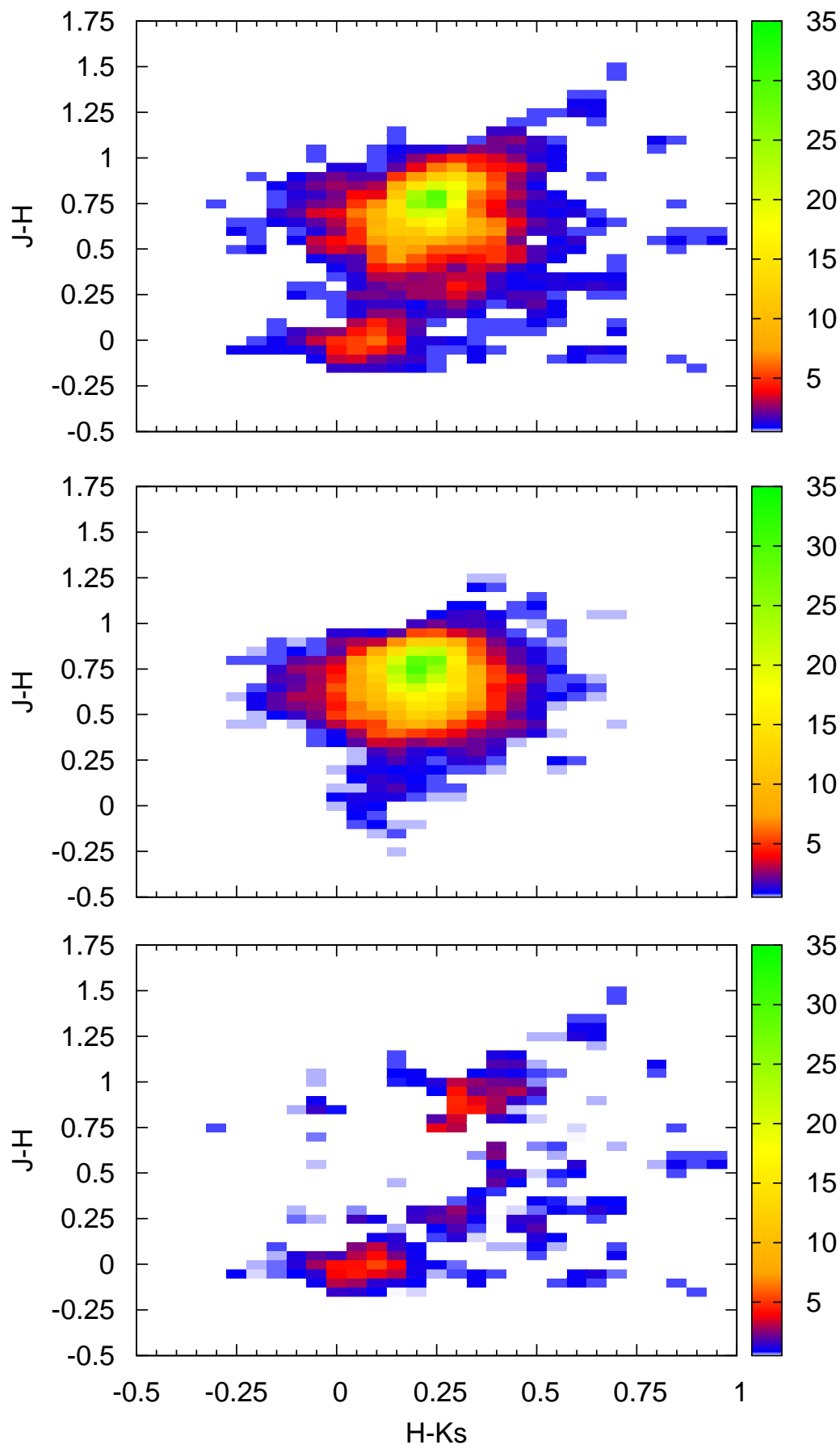

Figura 3.10: Diagramas color-color (en forma de diagramas de densidad). Panel superior: objetos ubicados en la región central (este diagrama incluye objetos propios de NGC604 + objetos de campo). Panel central: fuentes pertenecientes a la región de campo (cada intervalo fue multiplicado por el factor de escala entre las áreas de las regiones). Panel inferior: resta estadística de objetos de ambos diagramas, (región central - región de campo). 
con exceso IR.

2. Hay una población de estrellas masivas de MS y gigantes con poca extinción, ubicadas alrededor de $(H-K s) \sim 0.0$ y $(J-H) \sim 0.0$, evidentemente presentes en la región central y ausentes en la región de campo. Estos son objetos pertenecientes a NGC 604.

3. En el panel inferior aparece claramente (también se nota comparando los diagramas de ambas regiones aunque es menos evidente) un grupo de objetos alrededor de $(H$ $K s) \sim 0.25$ y $(J-H) \sim 1.0$, estrellas gigantes rojas del disco de M 33 con extinción.

En síntesis, la mayoría de los objetos de campo incluidos en el diagrama CC de la región central corresponden a la nube de puntos grises en la Figura 3.7, ubicados alrededor de $(H$ $K s) \sim 0.1$ y $(J-H) \sim 0.75$. Estas fuentes son estrellas de tipo espectral G - M de MS y gigantes rojas enrojecidas pertenecientes a M33 (recordar que el modelo de Besanson sólo estimó 6 objetos de la Vía Láctea en el campo).

\subsection{Distribución espacial de los objetos con exceso IR}

En las Secciones precedentes se mencionó que, entre los objetos que pueden presentar exceso IR intrínseco se encuentran todos aquellos que tienen envolturas circumestelares, ya sean objetos evolucionados, como estrellas gigantes Of y B[e], estrellas WR y Be con discos circumestelares, así como también objetos muy jóvenes (en formación). En estos últimos el exceso IR se origina en el gas y polvo localizado en los alrededores del objeto, el cual es calentado a altas temperaturas por la fuente central. Dicho material puede ser parte de la nube originaria (que aún no fue disipada por la nueva estrella) o puede ser material que forma un disco de acreción alrededor del objeto en formación todavía en proceso de contracción (Stahler \& Palla, 2004). En particular, con las observaciones utilizadas en el presente estudio, debido a la distancia a la que se encuentra NGC 604, entre las fuentes con exceso IR se espera encontrar principalmente, fuentes candidatas MYSOs y no objetos en formación de masa intermedia o baja.

La Figura 3.11 muestra la distribución global en el campo de NGC 604de los 692 objetos de la región central que fueron graficados en los diagramas CC y CM de las Figuras 3.7 y 3.8, respectivamente. La imagen de fondo corresponde a la banda $K s$ y se han superpuesto los contornos del continuo de radio en $8.44 \mathrm{GHz}$ adaptados del trabajo de Churchwell \& Goss (1999), en los cuales se han señalado los picos de emisión con las letras A, B, C, D y F, siguiendo la notación de los autores en el mencionado estudio. Los círculos amarillos señalan la posición de las fuentes que no presentan exceso IR, los rombos negros corresponden a los objetos con exclR $R_{0}$, los círculos verdes con exclR 1 , los círculos azules con exclR $R_{2}$ y los cuadrados rojos a los objetos con exceso IR extremo, exclR . $_{3}$.

La Figura 3.12 es una ampliación de la región central de la Figura 3.11, que abarca el área limitada por los contornos en el continuo de radio. En esta figura se han suprimido la imagen 
de fondo y los objetos que no presentan exceso IR (círculos amarillos de la Figura 3.11), con el fin de resaltar la distribución de los objetos con exceso IR en relación a los contornos de 8.44 $\mathrm{GHz}$.

En la Figura 3.11 (y más claramente en la Figura 3.12) se observa que los objetos con exceso IR se agrupan principalmente en las regiones de emisión nebular intensa (donde prácticamente no se encuentran objetos sin exceso IR, excepto algunos ubicados entre los nudos de emisión $A$ y $B$ ) siguiendo los contornos delineados por la emisión en el continuo de radio. En particular, los objetos con exclR $R_{3}$, se localizan formando grupos en los picos de emisión $A, B$ y $C$ mientras que, en el máximo $D$ hay un grupo importante de objetos con exclR $R_{1}$ y exclR $R_{2}$. En la región situada al norte de A-B y al este de C-D hay un grupo de objetos dispersos con excesos IR de todas las medidas.

En el Capítulo 4 se analizará la ubicación de los objetos con exceso IR en relación a la distribución de las distintas componentes del medio interestelar de la región. Pero es interesante mencionar ahora que en el estudio de Churchwell \& Goss (1999), los autores concluyen que son necesarias de cinco a ocho estrellas de tipo espectral O5 III para generar la ionización medida en esas zonas. Si se examina con detalle la Figura 3.12 y se cuenta la cantidad de objetos con exceso IR ubicados en los máximos de radio, se obtiene que hay una cantidad comparable de objetos en dichos nudos. En particular, para la región coincidente con el máximo A, MaízApellániz et al. (2004) en un exhaustivo estudio de las distintas fases de la componente gaseosa de NGC 604, señalan la existencia de una región HII 'llena' (en el estudio citado los autores utilizan la expresión 'filled HII' para diferenciarla de las 'superficies HII'), en la que podrían estar dándose procesos de formación estelar.

La distribución espacial de los objetos con exceso IR también es consistente con un estudio realizado por Tosaki et al. (2007). En dicho estudio, basados en observaciones de las transiciones del ${ }^{12} \mathrm{CO}, \mathrm{J}=1-0$ y J = 3-2 en $115 \mathrm{GHz}(\sim 2.607 \mathrm{~mm})$ y $345 \mathrm{GHz}(\sim 0.869 \mathrm{~mm})$ respectivamente, los autores deducen que el gas molecular que ocupa la región del arco coincidente con los contornos C-D y su extensión hacia el este, presenta condiciones apropiadas de altas temperaturas $(T \sim 60 \mathrm{~K})$ y altas densidades $\left(\mathrm{n}_{H_{2}}>10^{3}-10^{4} \mathrm{~cm}^{-3}\right)$ para propiciar y sostener actualmente procesos de formación estelar masiva. En Figura 3.13, tomada de la publicación del mencionado estudio, puede observarse la ubicación del gas molecular junto con los valores que toma el cociente de $\mathrm{CO}(\mathrm{J}=3-2) / \mathrm{CO}(\mathrm{J}=1-0)$ según se indica en la escala de colores en el borde superior de gráfico del panel izquierdo. En ese mismo trabajo los autores proponen un escenario de formación estelar secuencial en la región, en el cual el cúmulo central de NGC604, comprime el material molecular ubicado hacia el sur, generando una región propicia para la formación de una segunda generación estelar. Como se ha mencionado en el Capítulo 1, este escenario es reafirmado en un estudio recientemente publicado por Miura et al. (2010) en el cual analizan datos obtenidos de observaciones interferométricas de alta resolución de ${ }^{12} \mathrm{CO}$, junto con $\mathrm{HCN}$ y continuo de radio en $89 \mathrm{GHz}$. Finalmente, utilizando observaciones de NGC 604 tomadas de bases de datos públicas de varios instrumentos y en distintas bandas, 
Relaño \& Kennicutt (2009) respaldan muchos de los resultados de los estudios previos antes mencionados.

\subsection{Fracción de objetos con exceso IR}

\section{Conteo a escala global}

A partir de la información derivada del análisis del diagrama CC y teniendo en cuenta la contaminación por objetos de campo en la región central, se ha calculado la fracción total de fuentes que presentan exceso IR en el cúmulo de NGC 604, con el fin de 'situar' a NGC 604 en el contexto de otras regiones de formación estelar conocidas.

Esta idea fue motivada por un interesante estudio realizado por Haisch et al. (2001), quienes basándose en datos de siete regiones de formación estelar en la Vía Láctea, han encontrado una correlación entre la fracción de fuentes que presentan exceso IR $\left(\eta_{I R}\right)$ y la edad del cúmulo. Las consideraciones tenidas en cuenta para calcular $\eta_{I R}$ se encuentran detalladas en Haisch et al. (2000). Con los datos derivados de la fotometría infrarroja obtenidos en esta Tesis, fue posible aplicar al cúmulo de NGC 604 un análisis similar al seguido por Haisch et al. (2001). En los siguientes párrafos se describe dicho análisis y los resultados obtenidos.

En las secciones precedentes se mencionó que el número total de objetos en la región central es de 692 (dentro de los límites de la completitud, $\mathrm{J}=21.5, \mathrm{H}=20.5$ y $\mathrm{K}_{s}=20.5$ ), el número de objetos, bajo las mismas condiciones, pertenecientes a la región de campo (habiendo corregido por el factor de escala entre las áreas de las dos regiones) es de 566, con lo cual, en primera aproximación puede decirse que, en los datos con los que se realizó este estudio, el número de objetos propios de NGC 604 es 126. Ahora bien, los objetos con exceso IR más confiable (aquellos pertenecientes a los grupos exclR $R_{1}$, exclR $R_{2}$ y exc $I R_{3}$ ) en la región central suman 87 y en la región de campo son 13. Bajo una suposición sencilla pero válida, se puede considerar una corrección por contaminación con objetos de background/foreground, restando esos 13 objetos al número de fuentes con exceso IR en la región central. Entonces, $\eta_{I R}$ en la región central está dada por 74/126 $(\sim 59 \%)^{5}$. Los números absolutos de objetos representan una cota mínima; si se considera el efecto de la extinción en la región central ambos valores se verán afectados en forma semejante y el cociente se mantendrá alrededor del valor calculado.

Como se mencionó en el Capítulo 1, la edad para el cúmulo central de NGC 604 fue calculada por varios autores y la mayoría de ellos converge a un valor de $3-5 \times 10^{6}$ años. Con estos datos es posible incluir a NGC 604 en el diagrama de $\eta_{I R}$ pertenecientes a un cúmulo en función de la edad del cúmulo. La Figura 3.14 muestra dicho diagrama con los cúmulos galácticos considerados por Haisch et al. (2001) en donde se ha agregado un nuevo punto (indicado con

\footnotetext{
${ }^{5}$ Vale notar que este cálculo ha sido 'conservador' ya que no se han considerado los objetos pertenecientes al grupo excIR ${ }_{0}$ que, de acuerdo a su definición, son fuentes con exceso IR dentro de sus barras de error.
} 


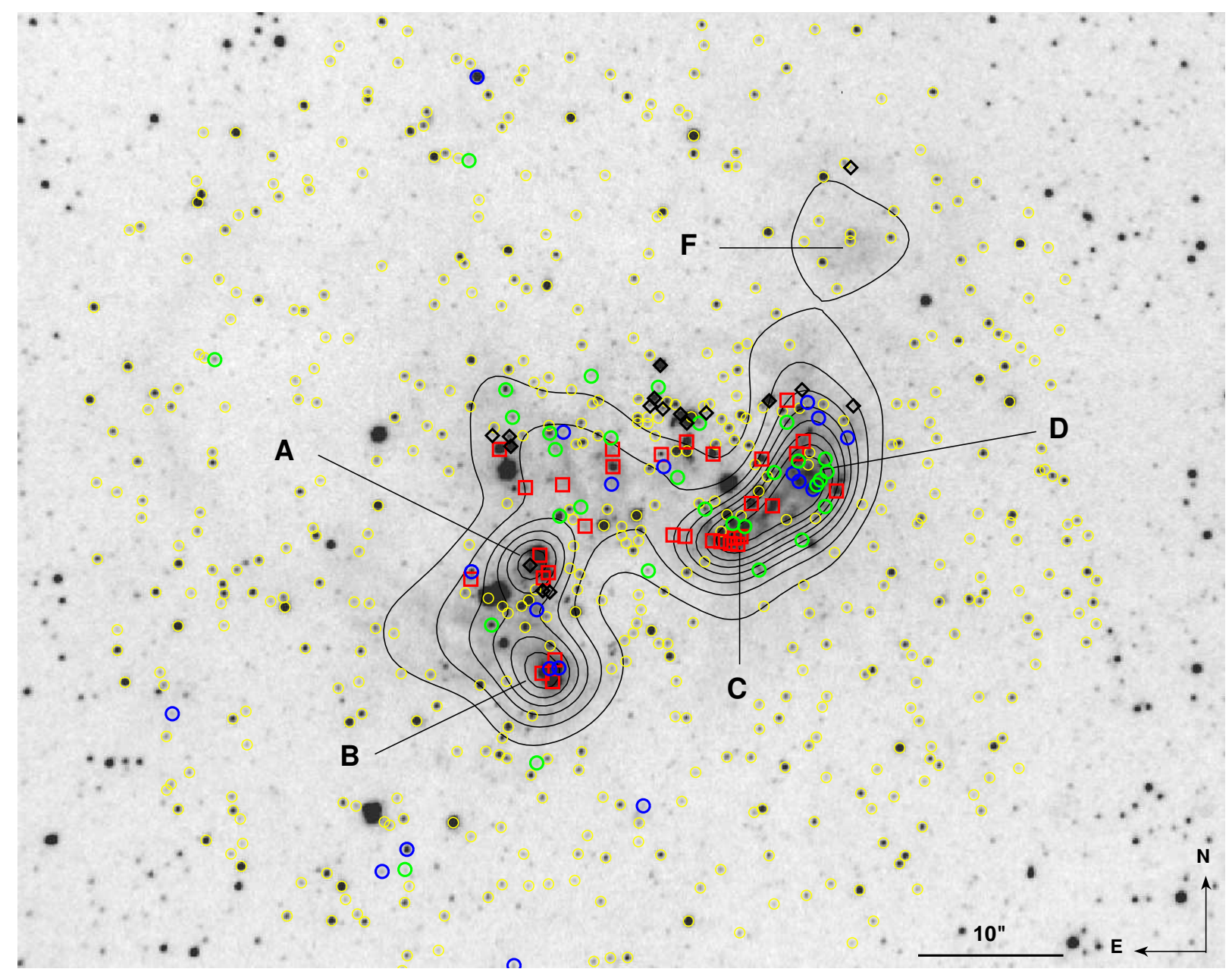

Figura 3.11: Distribución global en el campo de NGC604, de los 692 objetos de la región central que fueron graficados en los diagramas CC y CM de las Figuras 3.7 y 3.8, respectivamente. La imagen de fondo corresponde a la banda Ks y se han superpuesto los contornos del continuo de radio en $8.44 \mathrm{GHz}$ adaptados del trabajo de Churchwell 83 Goss (1999), en los cuales se han señalado los picos de emisión con las letras $A, B, C, D$ y $F$, siguiendo la notación de los autores. Los círculos amarillos señalan la posición de las fuentes que no presentan exceso $I R$, los rombos negros los objetos con excIR $R_{0}$, los círculos verdes excIR 1 , los círculos azules excIR y los cuadrados rojos los objetos con exceso IR extremo, excIR . 


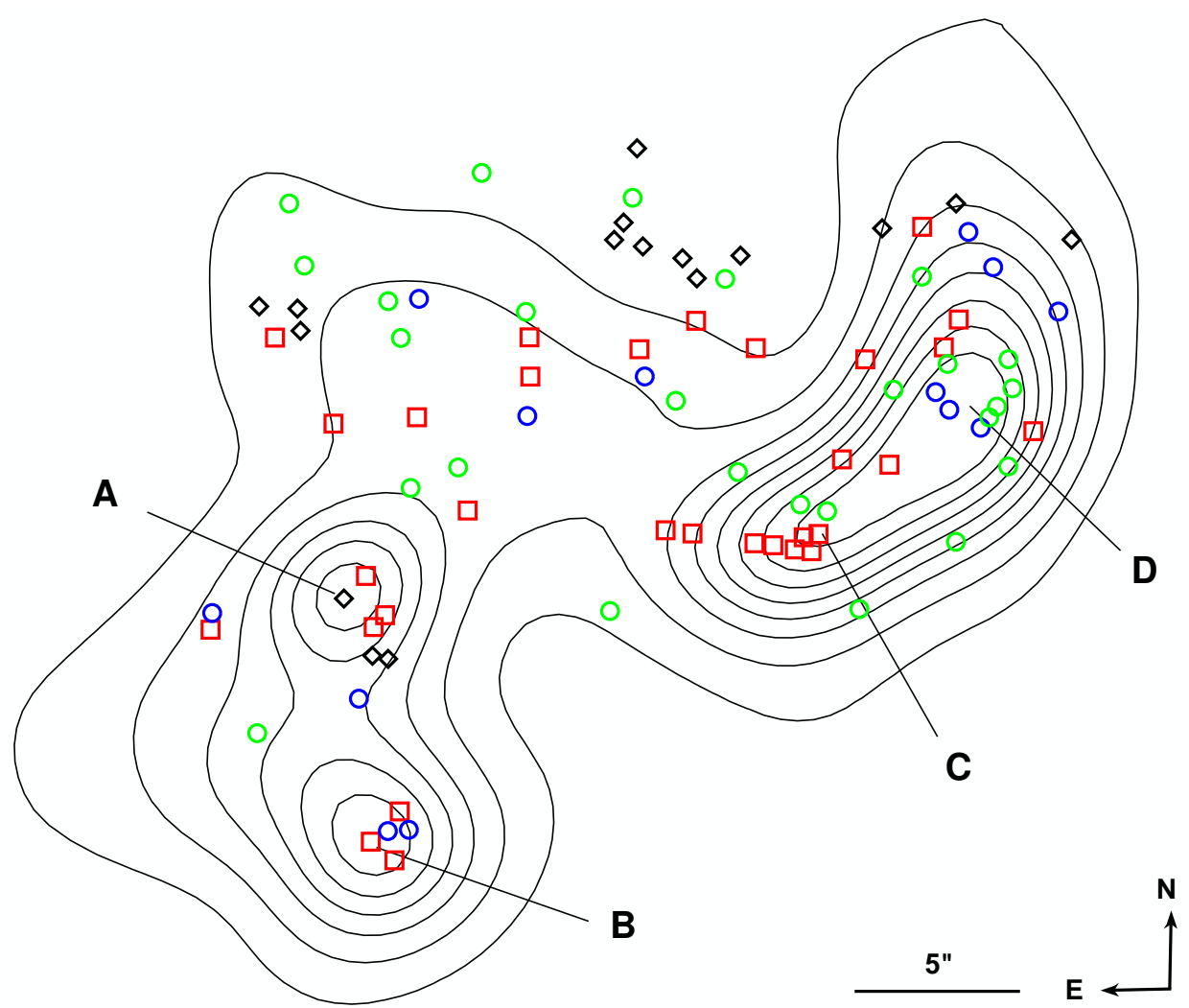

Figura 3.12: Ampliación de la región central de la Figura 3.11, que abarca el área limitada por los contornos en el continuo de radio a 8.44 GHz. En esta Figura se han suprimido la imagen de fondo y los objetos que no presentan exceso IR (círculos amarillos de la Figura 3.11), con el fin de resaltar la distribución de los objetos con exceso IR en relación a los contornos de $8.44 \mathrm{GHz}$.

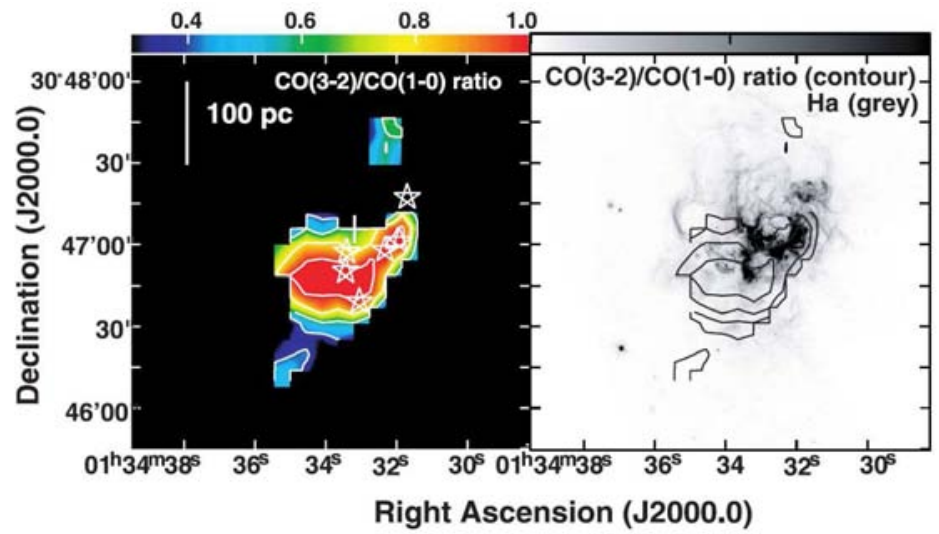

Figura 3.13: Figura tomada de Tosaki et al. (2007), donde se muestra la distribución del gas molecular que presenta condiciones apropiadas (de altas temperaturas y densidades) para propiciar y sostener actualmente procesos de formación estelar masiva. 


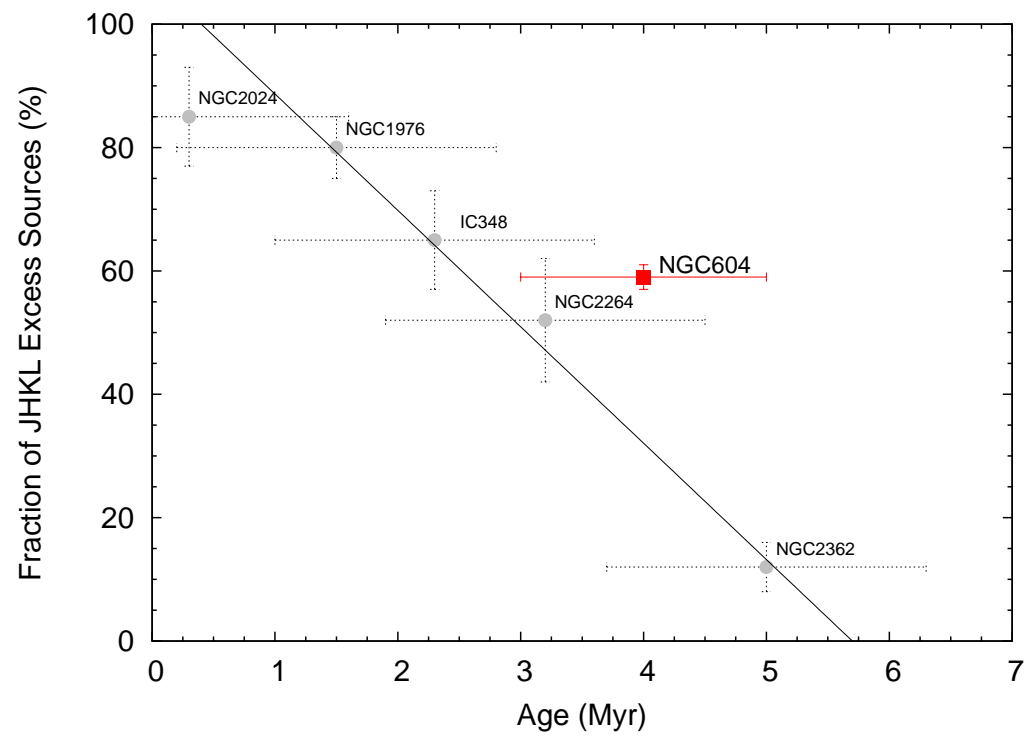

Figura 3.14: Diagrama de la fracción de objetos con exceso IR pertenecientes a un cúmulo en función de la edad del cúmulo. En este diagrama aparecen los cúmulos considerados por Haisch et al. (2001) y se ha agregado un nuevo punto (indicado con un cuadrado rojo) perteneciente a NGC 604 .

un cuadrado rojo) perteneciente a NGC 604.

Como puede observarse, NGC 604 se ubica por encima del ajuste de mínimos cuadrados realizado para los datos del estudio mencionado. Es importante notar que, en el caso de NGC 604, $\eta_{I R}$ fue calculada con fotometría en las bandas $J H K s$, mientras que en los datos de los demás cúmulos los autores incluyeron la banda $\mathrm{L}$. Se espera que los datos en la banda $\mathrm{L}$, incrementen $\eta_{I R}$ en un promedio del $10 \%$ (ver los resultados de Haisch et al., 2001), con lo cual, si se incluyeran datos de la banda L para NGC 604, su ubicación en el diagrama se desplazaría a un punto muy por encima del ajuste, es decir, NGC 604 presentaría un valor de $\eta_{I R}$ significativamente mayor de lo esperado para un cúmulo de $\sim 4 \times 10^{6}$ años, según el comportamiento de los cúmulos galácticos analizados.

Este resultado podría deberse a la presencia de una nueva generación de objetos masivos recientemente formados (o en proceso de formación). Estos objetos podrían generar un incremento en el número de fuentes con exceso IR, mientras que la determinación de la edad del cúmulo sigue siendo aun dominada por la generación previa de estrellas masivas. La presencia de una segunda generación de estrellas en los alrededores de zonas de formación estelar masiva ha sido propuesta y afirmada en base a evidencia observacional en varias regiones desde hace más de dos décadas (Walborn \& Parker, 1992; Brandner et al., 2001) y, como se mencionó anteriormente, en particular para el caso de NGC604, en estudios previos se ha señalado en la posibilidad de que en la región se estén produciendo actualmente procesos de formación estelar. 
Un último comentario respecto al análisis de $\eta_{I R}$ es que al incluir a NGC 604 en el diagrama de la Figura 3.14, se está comparando su ubicación relativa a una regresión que fue generada con cúmulos galácticos mucho menos masivos que NGC 604 y, al mismo tiempo, se está asumiendo que los objetos con exceso IR detectados en este estudio son candidatos a objetos masivos en formación (ver Figura 3.8). En el estudio realizado por Haisch et al. (2001), los autores relacionan las fuentes con exceso IR a fuentes con discos circumestelares y concluyen que, inicialmente, la fracción de fuentes con discos es muy alta ( $\gtrsim 80 \%)$ y decrece rápidamente con la edad creciente del cúmulo. De este modo, la mitad de las estrellas pierden sus discos en los primeros $3 \times 10^{6}$ años y calculan que la vida media de los discos, considerada a nivel global, es del orden de $6 \times 10^{6}$ años (siendo ésta la escala de tiempo en que prácticamente todas las estrellas de un cúmulo pierden sus discos). Si bien cada vez hay más estudios con observaciones que muestran la existencia de discos alrededor de estrellas masivas (ver Kraus et al. (2010), Follert et al. (2010), Schreyer et al. (2006) y Chini et al. (2004), entre muchos otros), como se mencionó en otras oportunidades, la existencia de estos discos es todavía un tema de discusión. De todo modos, el alto valor $\eta_{I R}$ encontrado para NGC 604 es ostensible y sería interesante poder ubicar más regiones gigantes de formación estelar masiva (en la escala de NGC 604 y 30 Dor) en dicho diagrama para comprobar si existe una tendencia de los cúmulos de alta masa a presentar una fracción mayor de objetos con exceso IR y, si tal tendencia existiese, encontrar su origen (vinculado a discos alrededor estrellas masivas o tal vez a otro mecanismo). Por otro lado, son necesarias nuevas observaciones espectroscópicas, detalladas y focalizadas en el estudio individual de los objetos candidatos a MYSOs identificados en NGC 604, para confirmar su verdadera naturaleza y estudiar en detalle el material circumestelar y las condiciones físicas que dan lugar al exceso IR en dichas fuentes (tal estudio, obviamente, también está vinculado a encontrar la causa del alto valor de $\eta_{I R}$, en particular para NGC 604).

\section{Conteo de objetos por regiones}

Se ha realizado también un conteo de objetos con exceso IR en subregiones dentro de NGC 604. La idea fue calcular el valor de $\eta_{I R}$ para las regiones seleccionadas y ubicarlas en el diagrama de $\eta_{I R}$ vs. edad del cúmulo, según el valor de $\eta_{I R}$ obtenido. Luego, bajo la suposición de que la regresión encontrada por Haisch et al. (2001) a partir de dicho diagrama, es aplicable a las subregiones individuales de NGC 604, es posible asignarles una edad estimativa y analizar el resultado obtenido en el contexto general de lo que se conoce de toda la región.

Las regiones individuales fueron ubicadas con centros coincidentes en los centros de las posiciones de los máximos de emisión en continuo de radio a $8.44 \mathrm{GHz}$, para los nudos AF del estudio de Churchwell \& Goss (1999), más una región adicional denominada X. Dicha región se encuentra ubicada en una de las cavidades principales de NGC 604, fuera de la región global abarcada por emisión en continuo de radio. La mayoría de los objetos de $\mathrm{X}$ pertenecen 
la componente principal de la SOBA de NGC 604. El área ocupada por X contiene una alta concentración de estrellas masivas evolucionadas, clasificadas como WR en estudios previos (ver Figura 3.17 y la descripción de tales fuentes en la siguiente Sección). Todas las regiones tienen un radio de $4^{\prime \prime}$, que a la distancia de NGC 604 corresponde aproximadamente a 16.5 pc, de modo que la dimensión de las regiones es del orden de magnitud de las dimensiones de las asociaciones $\mathrm{OB}$ y regiones de formación estelar masiva galácticas. La Figura 3.15 muestra la región central de NGC 604 donde se han señalado, con círculos rojos, la ubicación de las regiones sobre las cuales se ha calculado $\eta_{I R}$ (la dimensión de los círculos se corresponde con el radio de $4^{\prime \prime}$ considerado). Los contornos en línea delgada negra y los círculos en color rosa corresponden a la emisión en el continuo de radio y las regiones de los máximos de dicha emisión observada por Churchwell \& Goss (1999), las regiones se han graficado según las dimensiones citadas en ese estudio y se ha utilizado la nomenclatura allí definida para cada subregión. Los pequeños círculos turquesa son las estrellas de la región central y los cuadrados azules las fuentes que presentan exceso IR (pertenecientes a los grupos exclR $R_{1}$ exclR $R_{2}$ y exclR $R_{3}$ ).

El conteo de objetos para calcular el valor de $\eta_{I R}$ en cada región se llevó a cabo del mismo modo que el conteo realizado sobre toda la región descripto anteriormente. Cada subregión ocupa un área de $845 \mathrm{pc}^{2}$. En la región de control, en un área de $845 \mathrm{pc}^{2}$ hay 7 objetos en total y 0 objetos con exceso IR, de modo que estos son los valores considerados para la contaminación por objetos de campo. En estas subregiones la extinción toma valores en el rango de $\mathrm{A}_{V}=2.8-1.7$ mag (el valor más alto corresponde al nudo $A$ ), lo cual equivale $A_{K} \sim 0.28-0.17$ mag. Dadas las características del conteo que se desea realizar, se estima que una absorción $A_{K} \sim 0.28$ mag como máximo valor, tendrá una influencia mínima en los resultados obtenidos para $\eta_{I R}$ para cada subregión. Los resultados de los conteos junto con los parámetros principales de las regiones se encuentran listados en la Tabla 3.1, donde las Columnas 1, 2 y 3 corresponden a los nombres de las regiones y las coordenadas ecuatoriales celestes $(\alpha, \delta)$ Equinoccio J2000.0, la Columna 4 contiene el diámetro de las regiones de Churchwell \& Goss (1999), las Columnas 5 y 6 listan el número total de objetos con exceso IR y el número de objetos de la región (al cual ya se le sustrajeron los 7 objetos de campo) y la Columna 7 contiene el valor de $\eta_{I R}$ obtenido. Finalmente, en la Columna 8 se lista la edad aproximada que le correspondería a cada región aplicando la regresión de Haisch et al. (2001), según se muestra en el diagrama de la Figura 3.16 .

A partir de los resultados obtenidos en este ejercicio (teniendo presente todas la salvedades, limitaciones y fuentes de incertezas del mismo) se pueden realizar algunos comentarios y observaciones generales. Para empezar, las cuatro regiones que aparecen como más jóvenes son las coincidentes con los nudos de emisión en radio D, C, B y A, con edades entre 1 - 2 millones de años. Luego hay un salto de 2.5 millones de años hasta la edad derivada para la subregión $X$, de 4.5 millones de años, la cual es coincidente (dentro de los errores) con la edad calculada en estudios previos para el cúmulo central de NGC 604. Finalmente, las regiones más antiguas resultaron las coincidentes con la emisión de radio de los nudos $\mathrm{E}$ y $\mathrm{F}$, las cuales no contienen 


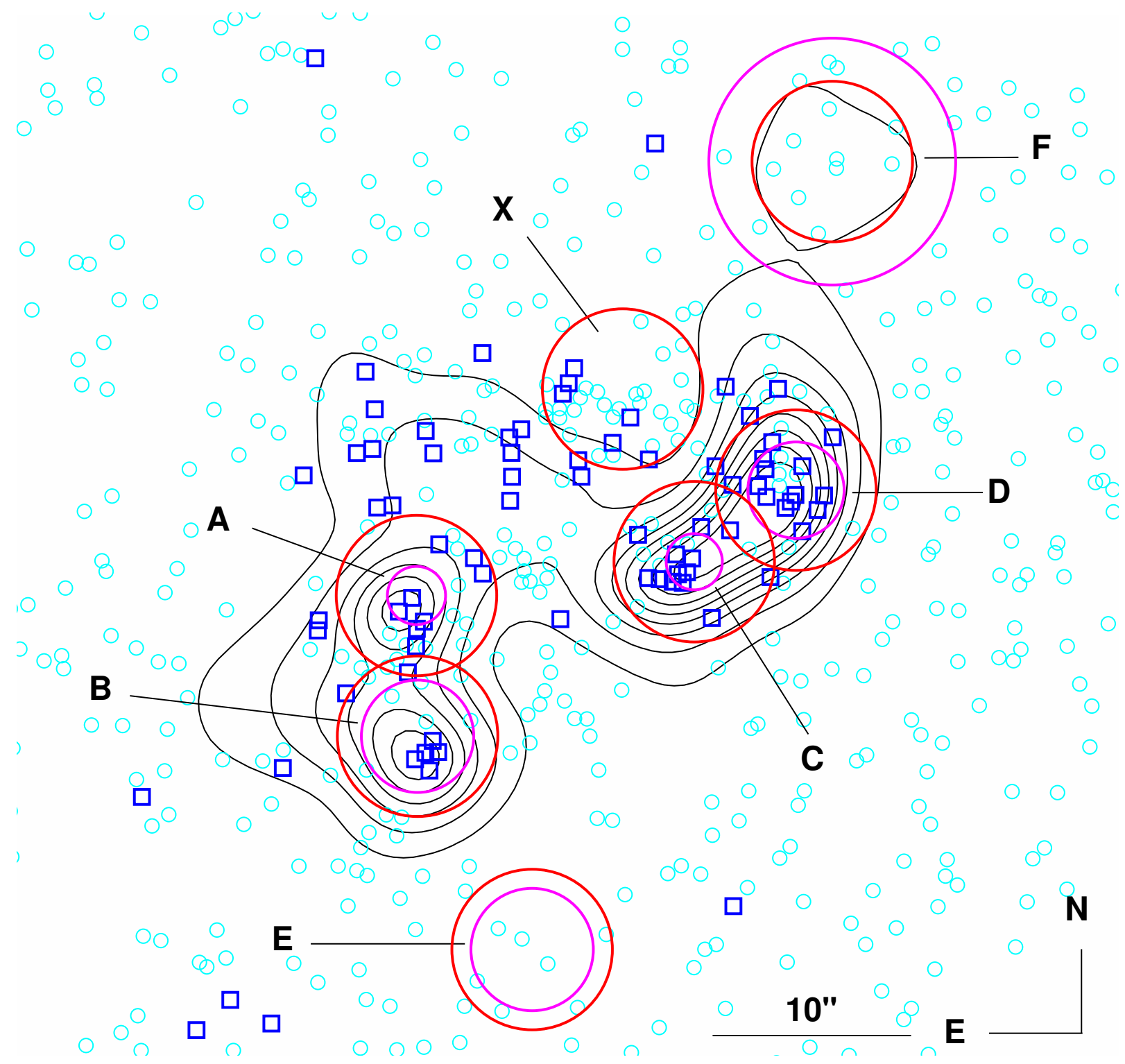

Figura 3.15: Región central de NGC604 donde se ha señalado, con círculos rojos, la ubicación de las regiones sobre las cuales se ha calculado $\eta_{I R}$; la dimensión de los círculos se corresponde con el radio de 4" considerado. Los contornos en línea delgada negra y los círculos en color rosa corresponden a la emisión en el continuo de radio y las regiones de los máximos de dicha emisión observada por Churchwell \& Goss (1999), las regiones se han graficado según las dimensiones citadas en ese estudio y se ha utilizado la nomenclatura alli definida para cada subregión. Los pequeños círculos turquesa son las estrellas de la región central y los cuadrados azules las fuentes que presentan exceso IR (pertenecientes a los grupos excIR $R_{1}$, excIR $R_{2}$ y excIR 3 . 


\begin{tabular}{cccccccc}
\hline $\begin{array}{c}\text { Región } \\
(1)\end{array}$ & $\alpha$ & $\delta$ & Diám. $\left({ }^{\prime \prime}\right)$ & IR total & Objetos & $\eta_{I R}(\%)$ & Edad (10 años) \\
$(2)$ & $(3)$ & $(4)$ & $(5)$ & $(6)$ & $(7)$ & $(8)$ \\
\hline A & 23.639208 & 30.782583 & 1.45 & 9 & 13 & 69 & 2.0 \\
B & 23.639333 & 30.780639 & 2.80 & 6 & 8 & 75 & 1.7 \\
C & 23.634708 & 30.782778 & 1.40 & 13 & 16 & 81 & 1.4 \\
D & 23.633000 & 30.783667 & 2.40 & 15 & 17 & 88 & 1.0 \\
E & 23.637708 & 30.777583 & 3.05 & 0 & 0 & 0 & 5.7 \\
F & 23.632083 & 30.788167 & 6.15 & 0 & 1 & 0 & 5.7 \\
X & 23.635685 & 30.785212 & $\ldots$ & 6 & 26 & 23 & 4.5 \\
\hline
\end{tabular}

Table 3.1: Resultados de los conteos junto con las características de las regiones en NGC 604. Las Columnas 1, 2 y 3 corresponden a los nombres de las regiones y las coordenadas $\alpha, \delta$ (J2000.0), la Columna 4 contiene el diámetro de las regiones de Churchwell $\&$ Goss (1999), las Columnas 5 y 6 listan el número total de objetos con exceso IR y el número de objetos de la región (al cual ya se le sustrajeron los 7 objetos de campo) y la Columna 7 contiene el valor de $\eta_{I R}$ obtenido. Finalmente, en la Columna 8 se lista la edad aproximada que le correspondería a cada región aplicando la regresión de Haisch et al. (2001).

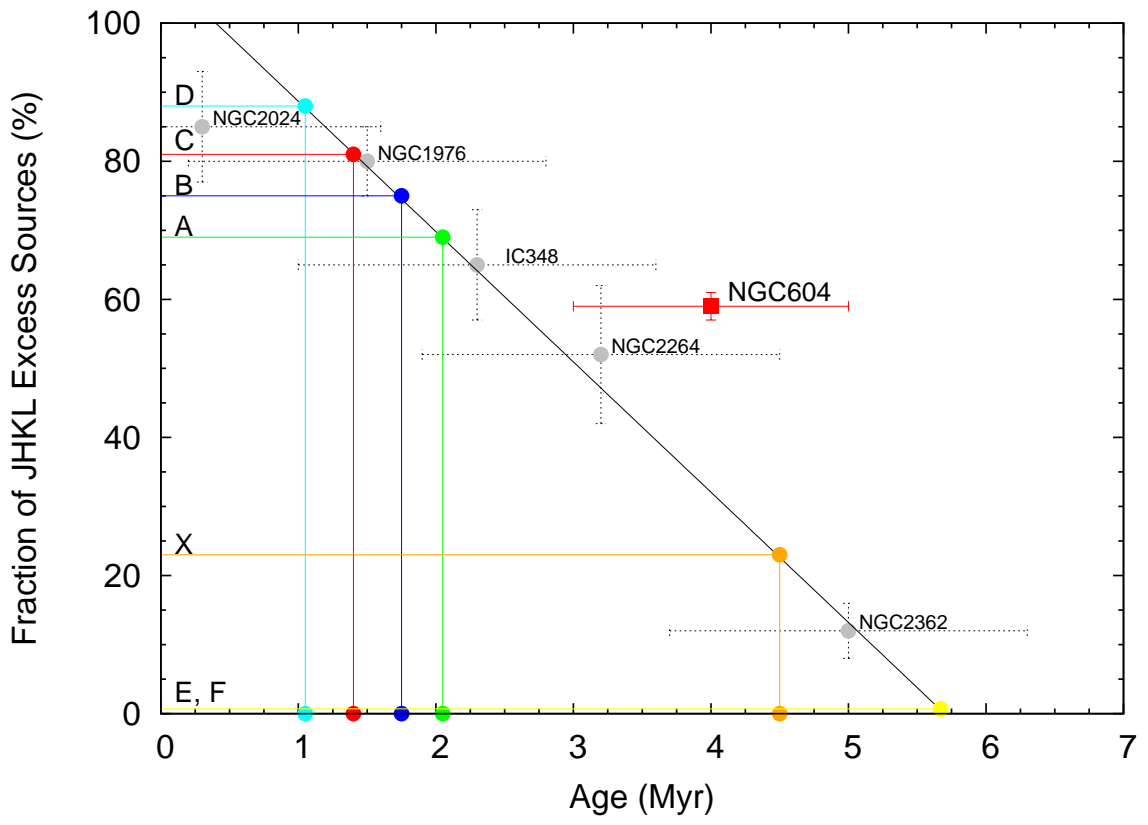

Figura 3.16: Diagrama de $\eta_{I R}$ vs. edad del cúmulo para distintas regiones de NGC 604. La edad de las subregiones fue obtenida a partir de la intersección entre fracción de objetos con exceso IR calculada para subregión ( $\eta_{I R}$ ) y la regresión derivada por Haisch et al. (2001), representada por la recta negra en el diagrama. 
objetos que presentan exceso IR.

Las regiones D, C y B se encuentran situadas en el arco de emisión nebular donde Tosaki et al. (2007) señalan la posibilidad de encontrar procesos de formación estelar actual. Mientras que la región A es coincidente con el lugar donde Maíz-Apellániz et al. (2004) proponen como región donde se podrían observar procesos de formación estelar inducida. Por otro lado, la región $F$ coincide con la ubicación del 'Cúmulo B' de Hunter et al. (1996) quienes afirman que dicho cúmulo tiene una edad similar a la del cúmulo central de NGC 604. La subregión E coincide con el SNR encontrado por Dodorico et al. (1980).

Los resultados obtenidos en este análisis, basados en datos de fotometría NIR de objetos individuales, son consistentes con la idea de que la mayoría de los objetos en las regiones $A, B, C$ y D pertenecen a una generación más reciente que la de la SOBA principal de NGC 604. Esta conclusión fue obtenida también a partir del análisis de las características de la emisión global del gas interestelar de la región.

Sin embargo, es conveniente llamar la atención, en este punto, sobre dos consideraciones importantes. La primera de estas consideraciones está directamente vinculada a análisis presentado: las edades obtenidas para cada subregión son sólo indicativas. Aun considerando la posibilidad de que la regresión encontrada por Haisch y colaboradores sea aplicable de forma la aquí presentada, las edades han sido derivadas de una estadística sencilla que involucra pequeños números, por consiguiente, son muy sensibles a modificaciones leves (por ejemplo, en el diámetro o las coordenadas del centro de las subregiones, las magnitudes límites consideradas, etc). La siguiente consideración es de carácter más general y relativa a la formación estelar secuencial: para establecer fehacientemente un escenario de formación estelar secuencial dentro de una región, son necesarias observaciones espectroscópicas detalladas de la componente estelar. No es fácil derivar, a partir de observaciones y consideraciones globales, una secuencialidad entre los episodios de formación estelar en las distintas zonas de una región de formación estelar masiva (las cuales además, en general presentan estructuras particularmente complejas, como es el caso en NGC 604 y 30 Dor entre otras). El rango de edades entre los objetos masivos evolucionados y los objetos masivos en formación es muy corto y queda diluido en las consideraciones globales. El hecho de que en una zona se observe material molecular a altas densidades y en otra subregión del mismo complejo, dicho material no sea observable no implica necesaria y únicamente una evolución temporal. Existe una gran cantidad de factores involucrados, como la distribución inicial de masas en la nube molecular previa al proceso de fragmentación, la forma en que se produce el colapso de los núcleos, la presencia de campos magnéticos, etc. Por otro lado hay que tener en cuenta siempre los factores geométricos (se observan proyecciones en dos dimensiones de estructuras tridimensionales). La posible secuencialidad en la formación estelar debe ser corroborada a partir de observaciones y estudios espectroscópicos de las características de los objetos individuales en cada zona de la región. Los estudios en escalas globales pueden ser indicadores de este efecto pero deben ser contrastados y confirmados. Un ejemplo concreto es lo sucedido en la región de formación estelar N159/N160 (en el límite sur de 30 Dor), don- 
de observaciones de la componente gaseosa del medio interestelar a nivel global, evidenciaban un efecto secuencial de formación estelar en la dirección norte-sur; sin embargo, estudios más detallados de la población estelar, concluyen que no es posible trazar una distinción clara entre distintos episodios de formación estelar (Fariña et al., 2009).

\subsection{Objetos individuales estudiados previamente}

NGC 604 es una región que ha sido ampliamente estudiada durante las últimas décadas. Muchos de los resultados de los estudios previos han sido compilados y explicados en forma resumida en el Capítulo 1. Allí se habrá advertido que gran parte de los estudios realizados sobre la región se han dedicado a estudiar las características globales y estructuras de gran escala de NGC 604 y en proporción, son pocos los estudios que se han focalizado en el análisis de objetos individuales. En la presente Sección se realiza un breve compendio sobre los objetos individuales previamente estudiados que están incluidos entre los objetos de los cuales se obtuvieron datos fotométricos en el presente trabajo. Las publicaciones sobre las cuales se basa esta revisión de objetos son básicamente dos: Bruhweiler et al. (2003) y Drissen et al. (2008) y serán referenciadas como B03 y D08 respectivamente. Estas dos publicaciones son las más completas para los própositos de esta Sección e incluyen a los objetos analizados en estudios previos a ellas. B03 clasificaron 40 estrellas en el campo de NGC 604, utilizando imágenes de HST-STIS en el UV $(\lambda=1170-1730 \AA ̊)$. D08 realizaron observaciones ópticas espectroscópicas de 14 estrellas con líneas de emisión en la región central, utilizando el espectrógrafo multiobjeto adosado al telescopio Canada-France-Hawaií (CFHT) de 3.6-m.

En la Figura 3.17 se han identificado, sobre una imagen de Gemini-NIRI de la banda $J$, los objetos previamente estudiados de los cuales se han podido obtener sus magnitudes en JHKs. Dichos objetos también se han graficado e identificado en los diagramas CC y CM de la Figura 3.18. En ambos diagramas los cuadrados rojos corresponden a las estrellas WR incluidas en el estudio de D08 y en las referencias citadas en dicho trabajo. Los círculos azules son objetos masivos con clasificación espectroscópica del estudio de B03. En el diagrama CM también se ha incluido, como referencia, la posición de los dos objetos galácticos conocidos, S106-IRS4 (objeto de Clase 0) y NGC2024-IRS2 (estrella masiva con disco) mencionados en las Secciones precedentes.

En la Tabla 3.2 se han listado los objetos incluidos en los gráficos. La Columna 1 es la identificación interna dada a los objetos (siguiendo la identificación asignada a los objetos en la Tabla 2.8 del Capítulo 1). La Columna 2 contiene el nombre en el estudio de referencia (las tres primeras letras identifican el estudio de referencia, las letras posteriores al guión identifican al objeto siguiendo la nomenclatura de dichos objetos en el estudio de referencia, estas últimas son las letras utilizadas para señalar a los objetos en las Figuras 3.17 y 3.18). La Columna 3 contiene la clasificación de las fuentes en los estudios previos y en las Columnas 4, 5 y 6 se han 


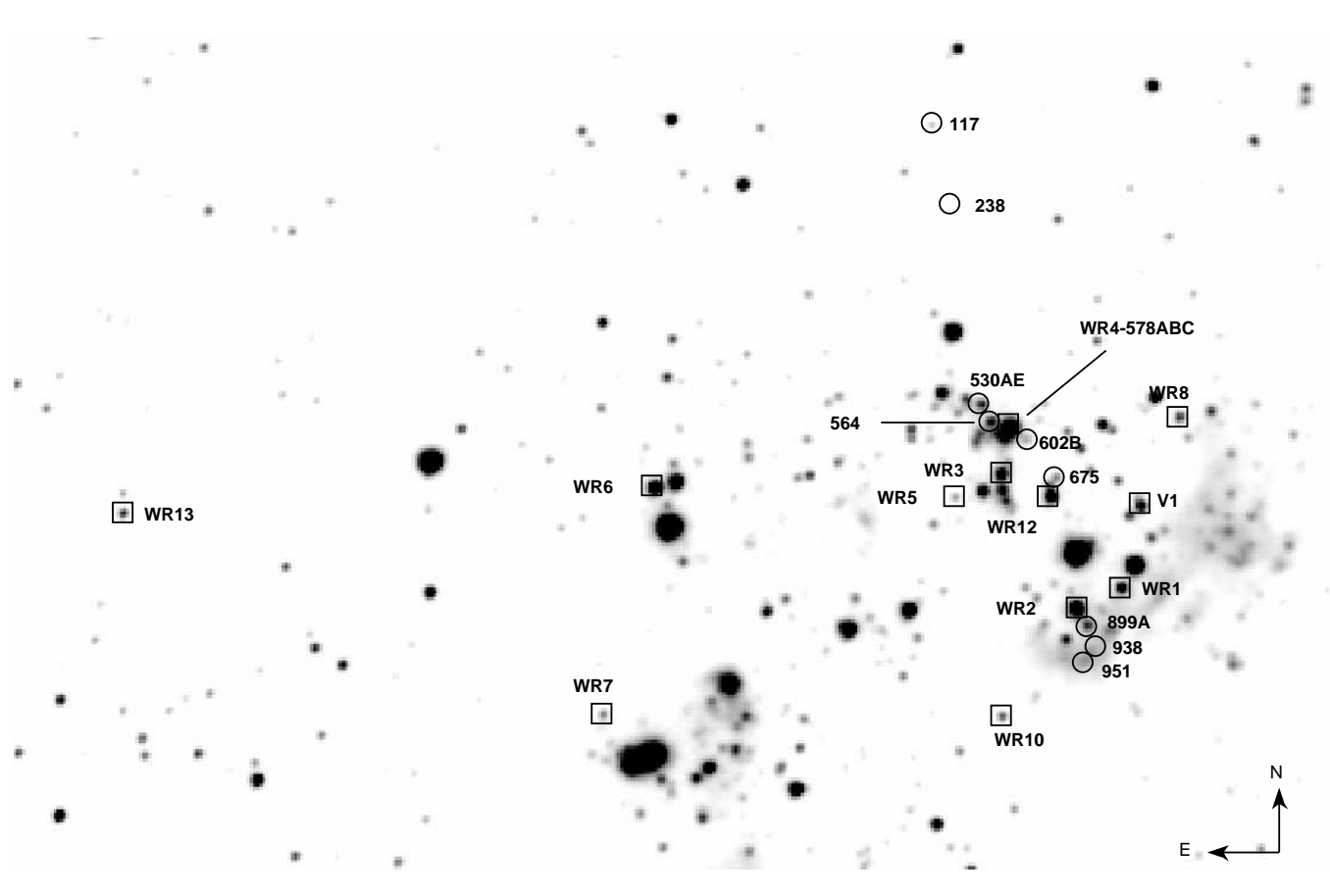

Figura 3.17: Imagen de Gemini-NIRI, de la banda J, sobre la que se han identificado los objetos conocidos de los cuales se han podido obtener sus magnitudes en JHKs.

incluido las medidas obtenidas en este estudio de la fotometría en las bandas $J, H$, y $K$ sy sus correspondientes incertezas. Los objetos que han sido marcados con ' ${ }^{\prime}$ ' en la Columna 1 , tienen un comentario particular en la siguiente Sección.

\section{Comentarios sobre objetos individuales}

Como se mencionó previamente, las estrellas WR pueden observarse como objetos con exceso IR en los diagramas CC y CM de la fotometría $J H K s$ debido a que son objetos que están siendo observados a través de sus propios vientos y envolturas que contienen polvo.

- D08-WR2 fue clasificada en un principio como WN por Conti \& Massey (1981), quienes en sus observaciones no podían resolverla lo suficiente como para clasificarla separadamente de D08-WR1. D08 no la incluyeron entre los objetos que observaron y B03 la clasificaron como dos estrellas de tipo espectral $\mathrm{O} 4 \mathrm{lab}-\mathrm{O} 4 \mathrm{la}$ debido a que identificaron dos objetos en esa posición. Estas estrellas son las más masivas y jóvenes en la muestra de objetos clasificados por B03. De la inspección visual de las imágenes de Gemini-NIRI resulta evidente que en la posición donde se encuentra D08-WR2 hay más de un objeto (en coincidencia con B03), sin embargo no se han podido resolver fotometricamente. En la fotometría JHKs, el color ( $H-K s$ ) del objeto medido en dicha posición, es más azul que el color esperado para una estrella WN, y a su vez, la magnitud en la banda $K s$ es más 

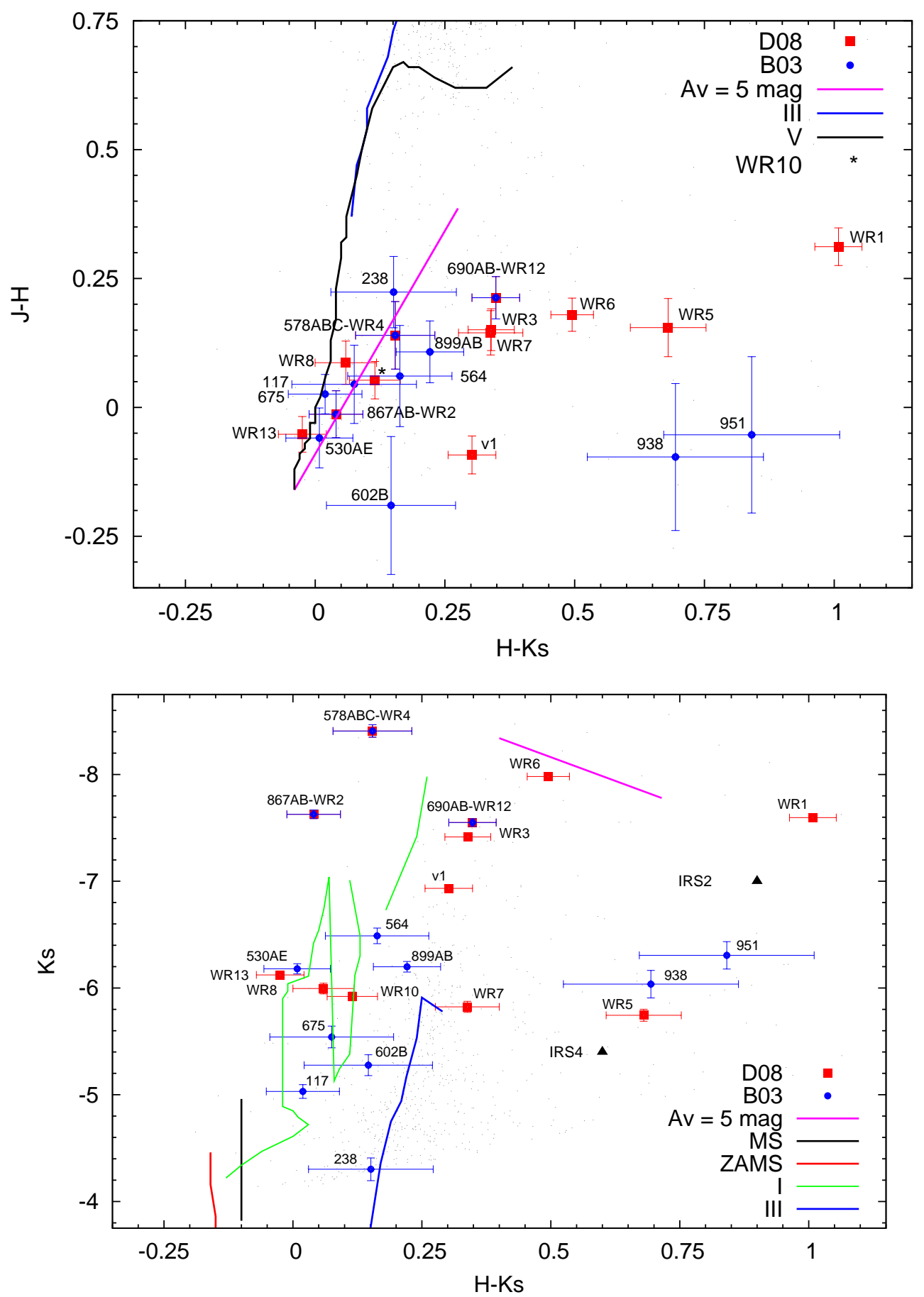

Figura 3.18: Diagramas color-color (panel superior) y color-magnitud (panel inferior) de los objetos previamente estudiados. En ambos diagramas los cuadrados rojos corresponden a las estrellas WR incluidas en el estudio de D08 y los círculos azules son objetos masivos con clasificación espectroscópica de B03. En el diagrama CM también se ha incluido, como referencia, la posición de los dos objetos galácticos conocidos, S106-IRS4 (objeto de Clase 0) y NGC2024-IRS2 (estrella masiva con disco). 


\begin{tabular}{cllccc}
\hline Id & Referencia & Clasificación & $\mathrm{J}$ & $\mathrm{H}$ & $\mathrm{K}_{s}$ \\
\hline 3791 & D08-WR1 & WCE & $18.32 \pm 0.03$ & $18.01 \pm 0.03$ & $17.00 \pm 0.04$ \\
1168 & D08-WR2, B03-867 A-B & WN, O4Iab-O4Ia & $17.00 \pm 0.03$ & $17.01 \pm 0.03$ & $16.97 \pm 0.04$ \\
3317 & D08-WR3 & WN & $17.68 \pm 0.03$ & $17.52 \pm 0.03$ & $17.19 \pm 0.04$ \\
3795 & D08-WR4, B03-578A-C & WN, O9II-O9Ia-09II & $16.49 \pm 0.04$ & $16.35 \pm 0.05$ & $16.19 \pm 0.06$ \\
1257 & D08-WR5 & WC6 & $19.69 \pm 0.03$ & $19.54 \pm 0.05$ & $18.56 \pm 0.06$ \\
1264 & D08-WR6 & WNL & $17.29 \pm 0.02$ & $17.11 \pm 0.02$ & $16.62 \pm 0.03$ \\
4021 & D08-WR7 & WC4 & $19.26 \pm 0.03$ & $19.12 \pm 0.03$ & $18.78 \pm 0.05$ \\
4096 & D08-WR8 & WN6 & $18.75 \pm 0.03$ & $18.66 \pm 0.03$ & $18.60 \pm 0.05$ \\
3255 & D08-WR10 & WN6 & $18.85 \pm 0.03$ & $18.79 \pm 0.03$ & $18.68 \pm 0.04$ \\
4075 & D08-WR12, B03-690A-B & WNE, O5III-BOIb & $17.61 \pm 0.03$ & $17.40 \pm 0.03$ & $17.05 \pm 0.04$ \\
1247 & D08-WR13 & O6.5Iaf & $18.40 \pm 0.02$ & $18.45 \pm 0.03$ & $18.48 \pm 0.04$ \\
1244 & D08-V1 & Of/WNL & $17.88 \pm 0.02$ & $17.97 \pm 0.03$ & $17.67 \pm 0.04$ \\
1631 & B03-117 & O4II & $19.61 \pm 0.02$ & $19.59 \pm 0.03$ & $19.57 \pm 0.06$ \\
1545 & B03-238 & O9III: & $20.67 \pm 0.04$ & $20.45 \pm 0.06$ & $20.30 \pm 0.11$ \\
1327 & B03-530A-E & O7V: & $18.37 \pm 0.04$ & $18.43 \pm 0.04$ & $18.42 \pm 0.05$ \\
4297 & B03-564 & O9II & $18.34 \pm 0.07$ & $18.28 \pm 0.07$ & $18.11 \pm 0.07$ \\
4380 & B03-602B & O9II & $19.28 \pm 0.11$ & $19.47 \pm 0.08$ & $19.32 \pm 0.10$ \\
4362 & B03-675 & O7II & $19.18 \pm 0.04$ & $19.13 \pm 0.06$ & $19.06 \pm 0.10$ \\
4224 & B03-899A & O7II & $18.73 \pm 0.04$ & $18.62 \pm 0.04$ & $18.40 \pm 0.05$ \\
4425 & B03-938 $^{c}$ & O6III:: & $19.16 \pm 0.09$ & $19.26 \pm 0.11$ & $18.56 \pm 0.12$ \\
4335 & B03-951 $^{c}$ & O8V & $19.08 \pm 0.10$ & $19.14 \pm 0.11$ & $18.29 \pm 0.13$ \\
\hline & & & & &
\end{tabular}

Table 3.2: Lista de los objetos previamente estudiados incluidos en los gráficos de las Figura 3.17 y 3.18. 'Id' es la identificación interna dada a los objetos (siguiendo la identificación asignada a los objetos en la Tabla 2.8 del Capítulo 1). La Columna 2 contiene el nombre en el estudio de referencia (las tres primeras letras identifican el estudio de referencia, las letras posteriores al guión identifican al objeto siguiendo la nomenclatura de dichos objetos en el estudio de referencia; estas últimas son las letras utilizadas para señalar a los objetos en las Figuras 3.17 y 3.18). La Columna 3 contiene la clasificación de las fuentes en los estudios previos y en las Columnas 4, 5 y 6 se han incluido las medidas obtenidas en este estudio de la fotometría en las bandas J, H, y Ksy sus correspondientes incertezas. Los objetos que han sido marcados con "c en la Columna 1, tienen un comentario particular. D08: Drissen et al. (2008), B03: Bruhweiler et al. (2003). 
brillante que la magnitud correspondiente a una estrella individual de tipo espectral O4 I, lo cual podría ser explicado si se considera que en dicha posición se está midiendo la emisión compuesta de dos (o tal vez más, recordando que para la distancia de NGC 604, $1^{\prime \prime}$ equivale a 4.1 pc) objetos no resueltos, coincidiendo con las observaciones de B03.

- D08-WR4 presenta una situación similar a la de D08-WR2. Fue clasificada como WN por Conti \& Massey (1981), quienes no podían resolverla de D08-WR3 y D08-WR5. D08 no obtuvieron un nuevo espectro para este objeto y en esa misma ubicación, B03 obtuvieron espectros correspondientes a tres objetos que fueron clasificados como dos estrellas de tipo espectral O9II y una O9 la. En las imágenes de Gemini-NIRI se obtuvo la magnitud correspondiente a un solo objeto en esa posición; sin embargo, al observar las imágenes es evidente que allí hay más que un objeto individual. En acuerdo con dicha observación, el color ( $H-K s$ ) y la magnitud en $K s$ llevan a concluir que se ha medido la magnitud correspondiente a la emisión combinada de varios objetos masivos (aunque no necesariamente evolucionados como una WR).

- D08-WR6 es uno de los objetos más brillantes de NGC 604. Fue clasificado inicialmente por Drissen et al. (1993) y posteriormente fue estudiado por Terlevich et al. (1996) quienes encontraron que muestra líneas espectrales excepcionalmente anchas $\left(\sim 2500 \mathrm{~km} \mathrm{~s}^{-1}\right)$, una sobreabundancia de He y una variabilidad espectral importante en escalas de tiempo de aproximadamente 10 años. Los autores clasificaron a esta fuente como un objeto en transición entre una estrella LBV y una WR.

- D08-WR8, conocida de estudios previos como una fuente candidata a estrella WR, fue precisamente clasificada por D08 como una estrella WN6. En las imágenes de HST de la banda F170W (UV), se distinguen claramente alrededor de su posición, dos objetos muy cercanos en proyección $\left(\sim 0.3^{\prime \prime}\right)$. En la fotometría de Gemini-NIRI sólo se obtuvieron valores de las magnitudes de un objeto, debido a que la separación entre ambas fuentes es del orden del límite de resolución de las imágenes de NIRI y también al hecho de que la fuente adyacente a D08-WR8 es cada vez más débil hacia longitudes de onda más largas. La contribución de la emisión del objeto cercano a D08-WR8 podría ser la causante de la ubicación, desplazada hacia el azul, de D08-WR8 en el diagrama CC.

- D08-WR12, se resuelve como dos fuentes en las imágenes de HST, y han sido clasificadas por B03 como estrellas de tipo espectral 05 III y B0lb. Sin embargo, D08 no están de acuerdo con dicha clasificación espectral (ya que está basada principalmente y casi únicamente en la presencia de la línea de emisión de HeII $\lambda 4686)$. D08 argumentan que si bien el único espectro que ellos obtuvieron corresponde al espectro compuesto de dos objetos; la mayor parte de la emisión de la línea debe provenir de la estrella más masiva (es la estrella B0 lb para B03), a la cual han clasificado como WN10. 
- B03-564 son dos estrellas, aunque en la fotometría de Gemini-NIRI no pueden resolverse.

- B03-938 fue clasificada por B03 como una estrella de tipo espectral O6 III:: (los '::' indican, como es habitual, una clasificación muy dudosa). En la imagen de HST-STIS F170W aparecen claramente dos objetos muy juntos en proyección. De nuevo en la fotometría de Gemini-NIRI no pueden resolverse. Estos objetos están situados sobre un arco de emisión nebular y en ese mismo arco está situada también B03-951. Seguramente a ello se deba la posición, desplazada hacia el rojo, de dichos objetos en los diagramas CC y CM. 



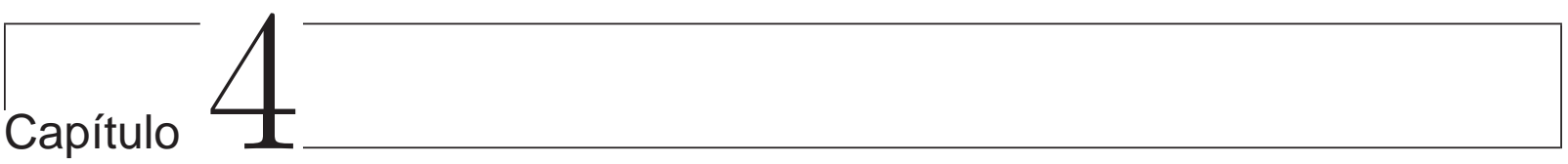

\section{Análisis y resultados derivados de los datos de banda angosta}

\subsection{Introducción}

En este Capítulo se expone el trabajo realizado principalmente con las imágenes de banda angosta de Gemini-NIRI $\left(\mathrm{Pa} \beta, \mathrm{Br} \gamma\right.$ y $\left.\mathrm{H}_{2}\right)$ y se discuten los resultados derivados del análisis de estos datos junto con datos incorporados de imágenes obtenidas con otros instrumentos en varias longitudes de onda. El análisis aquí presentado brinda información relativa a la componente nebular de la región: del $\mathrm{H}$ ionizado, mediante las líneas de recombinación $H \alpha, P a \beta$ y $B r \gamma$ y las imágenes de continuo de radio; del gas molecular, a través de la líneas de $H_{2}, \mathrm{CO}$ y HCN y del polvo presente en el medio interestelar, con imágenes en $8 \mu \mathrm{m}$. Esta información complementa lo obtenido con las imágenes de banda ancha.

El presente Capítulo contiene las siguientes secciones: • Imágenes para el estudio de la componente nebular: realiza una breve introducción sobre las imágenes utilizadas en el análisis presentado en este Capítulo y se comenta brevemente la reducción de las imágenes de banda angosta de Gemini-NIRI; • Mapas de cocientes de imágenes de banda angosta: explica el procedimiento general seguido (y el proceso sobre cada imagen) para generar los mapas de cocientes de imágenes de banda angosta de distintos telescopios. Dichos cocientes de imágenes serán los mapas de extinción cuando las imágenes sean calibradas en flujo; • Los objetos con exceso IR en el contexto global de NGC 604: se comentan las características más relevantes de los mapas de extinción obtenidos. Se presenta una descripción global del medio interestelar en la región integrando los datos de banda angosta de Gemini-NIRI con datos de otros instrumentos que mapean distintas componentes de medio interestelar; • Emisión en Br y $\mathrm{Ks}$ : se desarrolla un breve argumento respecto al posible origen del exceso IR de los objetos; • Objetos con emisión de $\mathrm{H}_{2}$ : se comenta sobre objetos individuales con emisión en $\mathrm{H}_{2}$. 



\subsection{Imágenes para el estudio de la componente nebular}

\subsubsection{Imágenes de banda angosta de Gemini-NIRI}

Las imágenes de banda angosta, en las cuales se centra el análisis presentado en este Capítulo, corresponden a los filtros de $\mathrm{Pa} \beta, \mathrm{Br} \gamma$ y $\mathrm{H}_{2}$, y fueron obtenidas con Gemini-NIRI. La descripción detallada sobre su adquisición y sus características principales se encuentran en el Capítulo 2). La Figura 4.1 muestra las curvas de transmisión de estos tres filtros de banda angosta. En dicha Figura también se han incluido los filtros de banda ancha ( $J, H$ y $K s$ ) con el fin de proveer una estimación visual de la longitud de onda central, el rango espectral y el porcentaje de transmisión de ambos conjuntos de filtros.

El proceso de reducción de las imágenes adquiridas con los filtros de banda angosta es igual al llevado a cabo con las imágenes tomadas con los filtros de banda ancha y se encuentra explicado en detalle en el Capítulo 2. Sólo se mencionará nuevamente que todas las imágenes fueron corregidas por 'vertical striping' y únicamente las imágenes del filtro $B r \gamma$ fueron corregidas por alinealidad, ya que el programa disponible (hasta octubre de 2010) para dicha corrección es aplicable a imágenes cuya tasa de conteo (count rate) supera las $20 \mathrm{ADU} \mathrm{s}^{-1}$. Como se observa en la Figura 2.8 del Capítulo 2, para las imágenes de $B r \gamma$ la mayoría de los pixeles presentan una tasa de alrededor de $25 \mathrm{ADU} \mathrm{s}^{-1}$, pero tanto para $P a \beta$ como para $H_{2}$, el máximo es menor a $10 \mathrm{ADU} \mathrm{s}^{-1}$.

A diferencia de lo que sucede con los filtros de banda ancha, no existe para los filtros de banda angosta un conjunto de estrellas estándares, en consecuencia, no es posible obtener una calibración directa en flujos absolutos. A esto se le suma además una difilcultad adicional dada por el hecho de que en el programa de observación de Gemini-NIRI no fueron incluidas observaciones con los filtros de los continuos adyacentes a las líneas, de modo que no es posible realizar una resta del continuo en forma directa.

\subsubsection{Otras imágenes que mapean la componente nebular}

Para completar el análisis presentado en este Capítulo se han incorporado datos correspondientes a otros instrumentos en una amplio rango de longitudes de onda, los cuales se detallan a continuación:

- Imágenes interferométricas obtenidas con el Nobeyama Millimeter Array (NMA) perteneciente al Nobeyama Radio Observatory (NRO) de Japón. Estos datos fueron gentilmente proporcionados por R. Miura del Observatorio de Japón. Los datos aquí utilizados fueron publicados en Miura et al. (2010). 


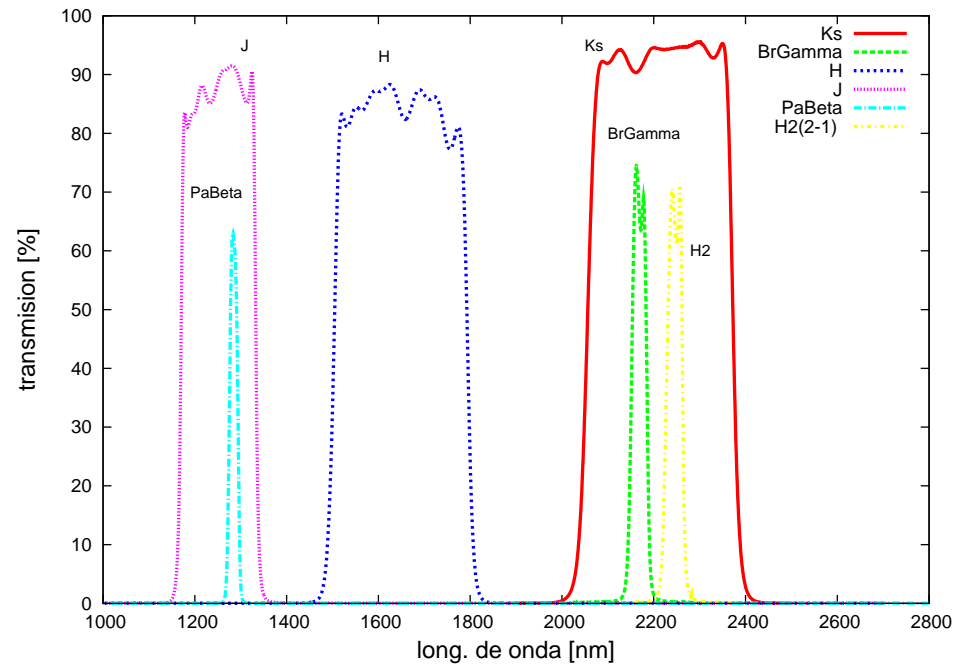

Figura 4.1: Curvas de transmisión de los filtros de Gemini-NIRI utilizados para la observaciones de esta Tesis, reproducidas según los valores de las tablas numéricas de las curvas de transmisión disponibles en las página web de NIRI.

- $\operatorname{HCN}(\mathrm{J}=1-0), \nu=115.27 \mathrm{GHz}(\lambda \sim 2.59 \mathrm{~mm})$, resolución 6.6".

- ${ }^{12} \mathrm{CO}(\mathrm{J}=1-0), \nu=88.63 \mathrm{GHz}(\lambda \sim 3.37 \mathrm{~mm})$, resolución $5.4^{\prime \prime}$.

- $89 \mathrm{GHz}$ (continuo), $\nu=88.98 \mathrm{GHz}(\lambda \sim 3.36 \mathrm{~mm})$, resolución $6.9^{\prime \prime}$.

- Imagen en el continuo de radio en $8.4 \mathrm{Ghz}(\lambda \sim 3.6 \mathrm{~cm})$ tomada con el Very Large Array (VLA), con una resolución de 2". Estos datos fueron gentilmente proporcionados por E. Churchwell. Los datos aquí utilizados fueron publicados en Churchwell \& Goss (1999).

- Imágenes del Telescopio Espacial Hubble (HST) obtenidas con la cámara Wide Field Planetary Camera 2 (WFPC2). Estos datos fueron gentilmente proporcionados por J. Maíz Apellániz. Los datos aquí utilizados fueron publicados en Maíz-Apellániz et al. (2004).

- F547M (continuo de F656), $\lambda=5476 \AA$, ancho $=483 \AA$

- $\mathrm{F} 656 \mathrm{~N}(\mathrm{H} \alpha), \lambda=6564 \AA$, ancho $=21 \AA$

- F658N ([N II]), $\lambda=6590 \AA$, ancho $=29 \AA$

- Imagen en $\lambda=8.0 \mu \mathrm{m}$ adquirida con el Telescopio Espacial Spitzer, con la cámara Infrared Array Camera (IRAC). La imagen fue tomada de la base de datos pública Infrared Science $\operatorname{Archive}^{1}$ (IRSA).

\footnotetext{
${ }^{1}$ http ://sha.ipac.caltech.edu/applications/Spitzer/SHA/
} 


\subsection{Mapas de cocientes de imágenes de banda angosta}

Como se explicó en Capítulo 1, los fotones ultravioletas emitidos por las estrellas masivas de la región, ionizan el medio interestelar en estado atómico y fotodisocian el medio interestelar en estado molecular. Los electrones del gas ionizado (principalmente $\mathrm{H}$ ) se recombinan generalmente en los niveles superiores de energía y luego prosigue una caída en cascada hacia niveles de energía inferiores, generando el espectro de líneas de emisión de $\mathrm{H}$ característico de las regiones HII. Las intensidades relativas de las líneas dependen de la temperatura y de la densidad del medio y están calculadas teóricamente.

Los fotones con longitudes de onda más cortas son más afectados por la dispersión y absorción producida por el polvo presente en el medio interestelar. Este efecto permite generar mapas de extinción a partir del cociente de imágenes obtenidas con filtros de banda angosta, centrados en diferentes líneas de recombinación del H. El apartamiento de los valores de los cocientes así generados, respecto al valor teórico correspondiente al cociente de la emisión de las líneas utilizadas, proporciona una medida de la absorción del medio interestelar producida por el polvo.

La figura 4.2 muestran una serie de curvas de extinción interestelar producida por el polvo (generadas para distintos modelos de composición del polvo) junto con medidas observacionales. En dicha figura se puede observar que en el rango de longitudes de onda de radio hasta el ultravioleta, los mapas de extinción serán más sensibles cuanto mayor sea la línea de base (en longitud de onda) entre las bandas con las que se genera el cociente. Teniendo en cuenta esta última observación, se han incorporado al conjunto de imágenes de banda angosta de GeminiNIRI, imágenes de HST, correspondientes al filtro $H \alpha($ F656N) obtenidas con la cámara WFPC2.

Las imágenes de banda angosta obviamente incluyen la línea de emisión y la contribución del continuo nebular y estelar. Las nebulosas gaseosas tienen un continuo intrínsecamente débil que consiste en una componente atómica y una componente de reflexión. El continuo atómico es generado principalmente por transiciones libre-ligado de $\mathrm{HI}$. La componente de reflexión proviene de la luz estelar dispersada por el polvo y, a mayores longitudes de onda, es generada por la radiación térmica emitida por el polvo (Osterbrock \& Ferland, 2006). El continuo de las imágenes de banda angosta proviene esencialmente de la contribución del continuo estelar y, en menor medida, del continuo nebular (que es más débil). Para calcular los valores de los cocientes de líneas a partir de las imágenes de banda angosta, con el fin de compararlos con los valores teóricos, es necesario restar la contribución del continuo de las imágenes de banda angosta.

NOTA:

En el presente Capítulo se describe cómo fueron realizados los cocientes de las imágenes de banda angosta con los cuales se generan los mapas de extinción. Sin embargo, dado que aun no 


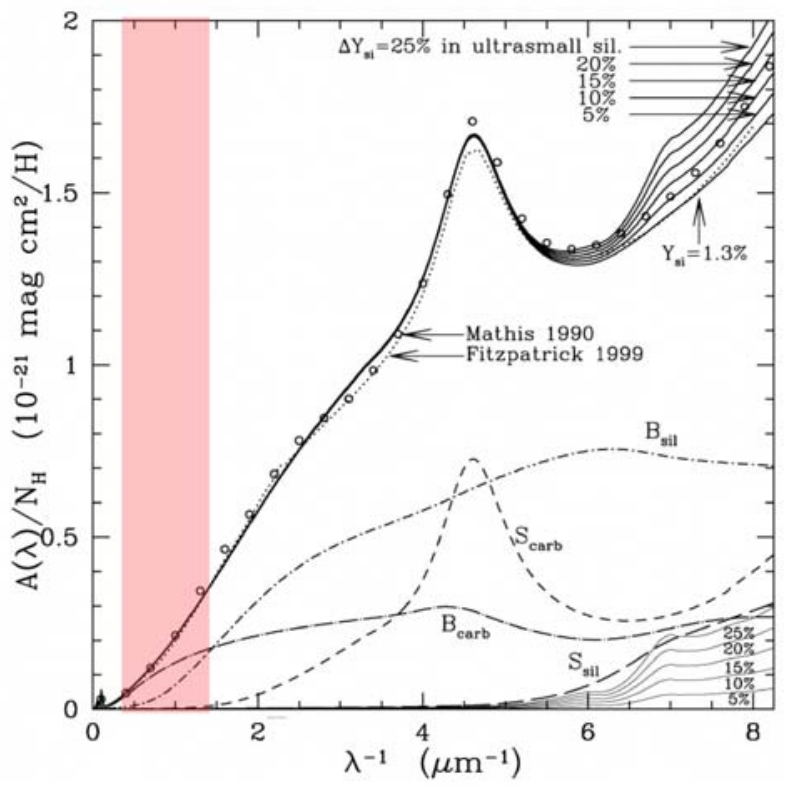

Figura 4.2: Serie de curvas de extinción interestelar producida por el polvo (generadas para distintos modelos de composición del polvo) junto con medidas observacionales. Imagen adaptada de Li $\&$ Draine (2001).

se ha realizado la calibración en flujo de las imágenes de Gemini-NIRI, con la expresión 'mapas de extinción' se está haciendo referencia a los cocientes de imágenes que trazan la extinción producida por el polvo presente en el medio interestelar. Habiendo hecho esta aclaración, con el fin de facilitar la redacción, se hará referencia a dichos cocientes de imágenes como 'mapas de extinción' (que es lo que serán una vez que las imágenes utilizadas estén calibradas en flujo).

\subsubsection{Resta del continuo de las imágenes de banda angosta de Gemini-NIRI: $\mathrm{Pa}, \mathrm{Br} \gamma \mathbf{y} \mathrm{H}_{2}$}

Debido a que para las imágenes de Gemini-NIRI de banda angosta no se han tomado imágenes con un filtro de continuo libre de la contribución de la emisión nebular, la resta del continuo se realizó utilizando el filtro de banda ancha que incluye a la línea cuyo continuo se desea restar, es decir: $J$ para restar el continuo a $\mathrm{Pa} \beta$ y $\mathrm{Ks}$ para restar el continuo a $\mathrm{Br} \gamma$ y $\mathrm{H}_{2}$ (ver Figura 4.1).

El procedimiento seguido para realizar la resta de continuo de las imágenes de banda angosta consiste en los pasos descriptos a continuación:

1. Se dividen las imágenes por su tiempo de exposición (ya que tienen distinto tiempo de exposición), de esta forma se normalizan las imágenes a unidades de $\mathrm{ADU} \mathrm{s}^{-1}$. 
2. Se estima un valor medio representativo de la emisión de fondo de cada imagen (emisión de fondo de 'cielo' no nebular) y se sustrae de las imágenes. Dicho valor fue obtenido utilizando el valor de la moda, calculada por la tarea IMSTATISTICS, en distintas regiones de la imagen sin emisión nebular evidente. La idea es que el valor de fondo (no nebular) de las imágenes luego de realizada la resta de la emisión de fondo quede alrededor de cero.

3. Las imágenes tienen distinto FWHM por una combinación de factores entre los cuales están el filtro utilizado y las condiciones atmosféricas en las que fueron tomadas. Como se detalló en el Capítulo 2, las imágenes de cada filtro se tomaron en distintos días, a diferentes masas de aire, etc. En general, las imágenes de banda ancha tienen un $\mathrm{FWHM}=0.35^{\prime \prime}$ y en las imágenes de banda angosta el FWHM tiene valores mayores. Por este motivo, en necesario realizar una convolución (con un núcleo gaussiano) para degradar la resolución de la imagen de mayor resolución y llevar el valor de su FWHM inicial, al valor del FWHM de la imagen de menor resolución (mayor FWHM).

Empatar el FWHM de los objetos puntuales de las imágenes (obviamente conservando el flujo total) es una manera de generar un perfil de los objetos parecido en ambas imágenes, de tal modo que la resta de los mismos no genere 'artefactos' en la imagen final, como núcleos sobrerrestados rodeados de halos en emisión subrrestados. Si bien la componente nebular presenta una emisión extendida que no se verá afectada por estas imperfecciones de pequeña escala en la imagen, lo ideal es generar una imagen nebular lo más 'limpia' posible y aprovechar la excelente resolución espacial de las imágenes para realizar un análisis de las estructuras en la mayor resolución posible.

La relación entre el FWHM inicial de una imagen y el FWHM de la imagen resultante de su convolución con una función gaussiana, se obtiene a través de la dispersión de la gaussiana, $\sigma_{c o n v}$, mediante la siguiente fórmula:

$$
\sigma_{\text {final }}^{2}=\sigma_{\text {conv }}^{2}+\sigma_{\text {inicial }}^{2}
$$

donde:

$\sigma=\mathrm{FWHM} / 2.355$

$\sigma_{\text {inicial }}$ corresponde al FWHM de la imagen de banda ancha.

$\sigma_{\text {final }}$ corresponde al FWHM de la imagen de banda angosta.

$\sigma_{c o n v}$ es la dispersión de la gaussiana con la que se va a realizar la convolución.

La convolución se puede efectuar utilizando la tarea GAUSS de IRAF. El valor obtenido de $\sigma_{\text {conv }}$ utilizando la ecuación precedente, es un valor de referencia inicial. Debido a que la PSF de las estrellas no es gaussiana fue necesario hacer un ajuste al valor inicial de $\sim 20 \%$. Para obtener el valor del FWHM en cada imagen, se midió el FWHM de 30 fuentes estelares ampliamente distribuidas en la imagen. 
Un último comentario con relación a la convolución, es que en la tarea GAUSS el valor de $\sigma_{\text {conv }}$ hay que ingresarlo en unidades de pixeles. Sin embargo, hay que tener presente que lo que se desea igualar es el FWHM 'real' de las imágenes, es decir, el FWHM medido, por ejemplo, en segundos de arco. En este caso en particular, en el que se han utilizado imágenes adquiridas con el mismo instrumento en idéntica configuración instrumental, este comentario parece trivial ya que, siendo la escala espacial de los pixeles la misma, resulta indistinto medirlo en pixeles o segundos de arco, pero se vuelve importante cuando se trabaja con imágenes de distintos telescopios o del mismo telescopio pero adquiridas con una configuración instrumental diferente, en la cual se cambie la escala de los pixeles.

4. Para cada uno de los 30 objetos mencionados en el item anterior, además del FWHM también se midió el flujo en la imagen de banda angosta y en su correspondiente imagen de banda ancha, y se calculó el cociente entre ambas medidas. El valor del promedio de los 30 cocientes calculados se adoptó como valor inicial para la relación de escala entre los flujos de la imagen de banda angosta y su correspondiente imagen de banda ancha. Es necesario considerar dicha relación de escala para efectuar la resta de continuo, ya que da cuenta del hecho de que los filtros tienen distinta cobertura espectral y distinto porcentaje de transmisión.

Al calcular la relación de escala de este modo, hay una suposición implícita importante: se está asumiendo que la línea correspondiente a la imagen de banda angosta con la cual se calcula el factor de escala, constituye la única (o al menos la más importante) contribución de línea en el rango de longitudes de onda obarcado por el filtro de banda ancha. Si bien esta suposición no es estrictamente cierta, permite obtener un valor inicial para dicha escala que, como en el caso del FWHM, se irá ajustando iterativamente hasta converger en el valor con el cual se logra la mejor resta de las imágenes.

Una manera rápida de corroborar el orden de magnitud de este factor de escala es comprobando que coincide, dentro de cierta tolerancia, con el valor del cociente de las 'áreas' de los filtros (teniendo en cuenta la transmisión y el ancho de la banda).

Como se mencionó anteriormente, los objetos utilizados para calcular el factor de escala fueron seleccionados de manera tal que, en las imágenes de banda angosta, dichos objetos caen fuera de las zonas donde la emisión nebular es evidente.

5. Una vez definidos los valores de $\sigma_{\text {conv }}$ y del factor de escala entre los flujos, se convoluciona la imagen de banda ancha utilizando la tarea GAUSS y, con la tarea IMCALC, se restan las imágenes multiplicando por el factor de escala correspondiente. De este modo, tomando la imagen de $B r \gamma$ como ejemplo, la imagen de $B r \gamma \sin$ continuo, $i m_{B r \gamma_{s / c}}$, se obtiene calculando:

$$
i m_{B r \gamma_{s / c}}=i m_{B r \gamma}-i m_{K_{s} c o n v} \times \alpha
$$

donde $i m_{K_{s} c o n v}$ es la imagen de $K s$ convolucionada y $\alpha$ el factor de escala entre los flujos. 


\begin{tabular}{llll}
\hline & $P a \beta$ & $B r \gamma$ & $H_{2}$ \\
\hline$\sigma_{\text {conv }}$ (pixels) & 2.1 & 1.2 & 0.71 \\
$\alpha$ & 0.071 & 0.069 & 0.067 \\
Fondo banda ancha (ADU) & $32.0(\mathrm{~J})$ & $135.5(\mathrm{Ks})$ & $135.5(\mathrm{Ks})$ \\
Fondo banda angosta (ADU) & $6.7(\mathrm{~Pa} \beta)$ & $28.7(\mathrm{Br} \gamma)$ & $9.0\left(\mathrm{H}_{2}\right)$ \\
\hline
\end{tabular}

Table 4.1: Lista de valores de $\sigma_{\text {conv }}$, escala entre los filtros $(\alpha)$, y valor medio de cielo en cada imagen, utilizados para la resta de continuo de las imágenes de banda angosta.

Los valores finales de las cuentas (en ADU) para la resta de fondo de las imágenes, $\sigma_{\text {conv }}$ y los factores de escalas utilizados para la resta de continuo de $\mathrm{Pa} \beta, \mathrm{Br} \gamma$ y $\mathrm{H}_{2}$ se encuentran listados en la Tabla 4.1.

La Figura 4.3 muestra, a modo ilustrativo, las imágenes de banda angosta originales, con continuo (paneles del lado izquierdo) y sus correspondientes imágenes después de haberse efectuado la resta de continuo (paneles del lado derecho). Todas las imágenes se exhiben con el mismo despliegue, el cual muestra en escala lineal de grises el $99.5 \%$ de la distribución de cuentas de la imagen. La escala está invertida, con lo cual, la emisión más intensa corresponde al color negro y la menos intensa al color blanco. Como se observa, las imágenes con resta de continuo muestran la emisión nebular extendida y prácticamente no exhiben objetos estelares.

Si se presta atención a los paneles que corresponden a la imagen del filtro $\mathrm{H}_{2}$ en la Figura 4.3, se nota que una vez restado el continuo, la imagen de $H_{2}$ resultante es una imagen de bajo brillo superficial, en la que no aparecen estructuras en emisión nebular extendida demasiado evidentes. Este resultado era esperable ya que las líneas de hidrógeno molecular son observables en ambientes de condiciones extremas de densidad $\left(\mathrm{n}_{H}>10^{6} \mathrm{~cm}^{-3}\right)$ y temperatura $(T>2000 \mathrm{~K})$. La emisión de $\mathrm{H}_{2}$ se encuentra normalmente asociada a nubes irradiadas por estrellas masivas cercanas (en regiones de fotoionización) o expuestas a frentes de choques de vientos estelares (vinculadas con 'outflows' estelares). El caso interesante en NGC 604, es que luego de la resta de continuo, en las imágenes de NIRI se descubrieron dos objetos con emisión exclusivamente en $H_{2}$, los cuales se describirán en la Sección 4.6.

La Figura 4.4 se incluyó con la idea de señalar algunas de las características de las imágenes de banda angosta con el continuo restado haciendo referencia al origen de las mismas en la imagen una de las imágenes usadas como continuo. En la figura los paneles de izquierda a derecha corresponden a las imágenes de los filtros $\mathrm{Ks}, \mathrm{Pa} \beta, \mathrm{Br} \gamma$ y $\mathrm{H}_{2}$ ( $\mathrm{Ks}$ fue usada como continuo para $\mathrm{Br} \gamma$ y $\mathrm{H}_{2}$ ). En las cuatro imágenes se marcaron, con el mismo código de colores, los objetos estelares que dan origen a algunos de los residuos que aparecen mal restados en las imágenes de banda angosta sin continuo. De este modo, los círculos rojos señalan estrellas 


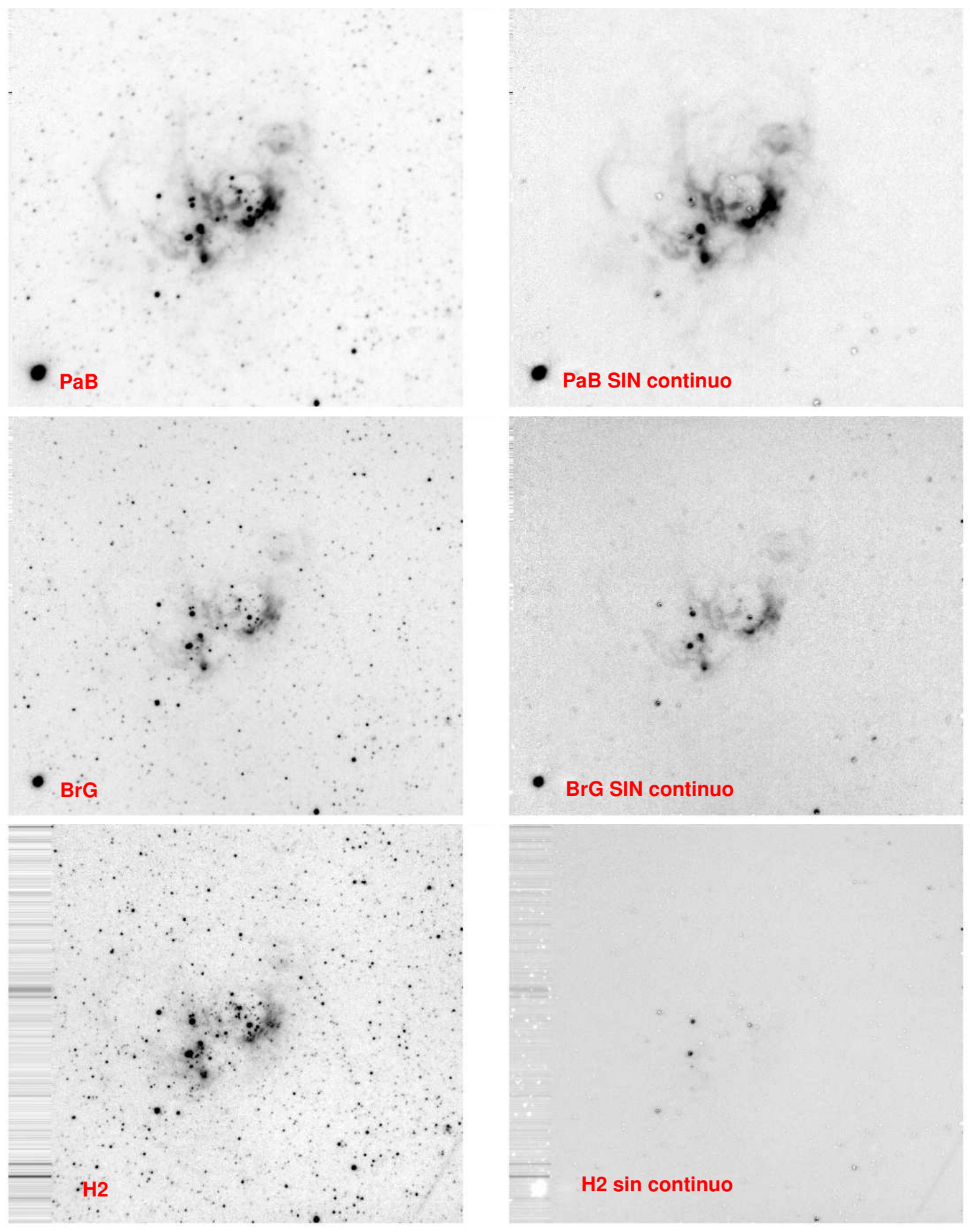

Figura 4.3: Imágenes de banda angosta originales, con continuo (paneles del lado izquierdo) y sus correspondientes imágenes después de haberse efectuado resta de continuo (paneles del lado derecho). Todas las imágenes se exhiben con el mismo despliegue, el cual muestra en escala lineal de grises el $99.5 \%$ de la distribución de cuentas de la imagen. La escala está invertida, con lo cual, la emisión más intensa corresponde al color negro y la menos intensa al color blanco. 


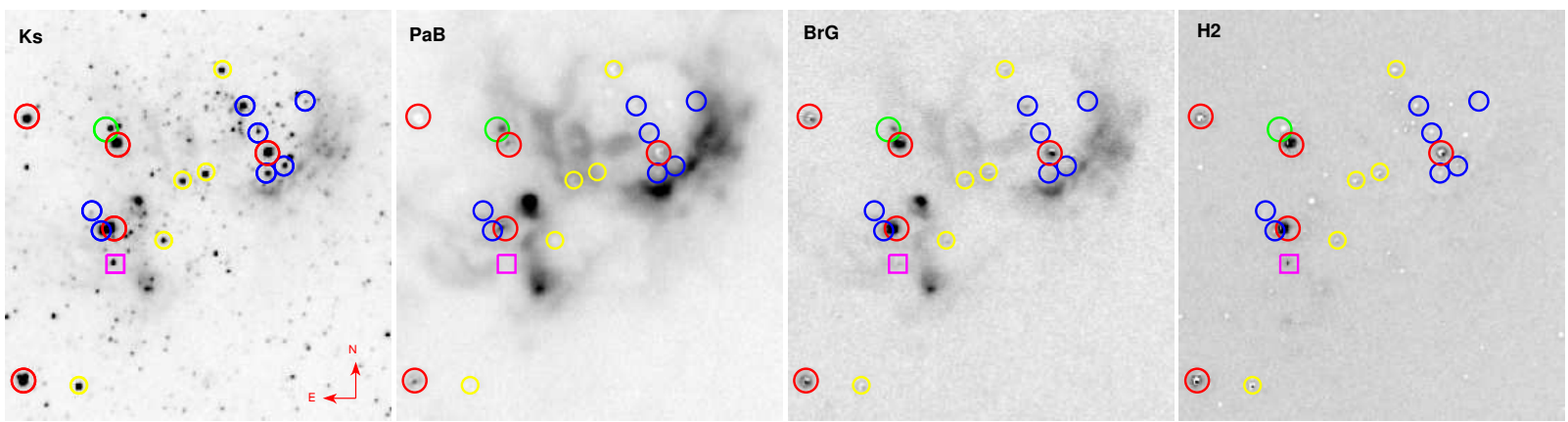

Figura 4.4: Paneles de izquierda a derecha: imagen de la banda Ks, Paß, Bry y $\mathrm{H}_{2}$ (Ks fue usada como continuo para $\mathrm{Br \gamma}$ y $\mathrm{H}_{2}$ ). En las cuatro imágenes se marcaron, con el mismo código de colores, los objetos estelares que dan origen a algunos de los residuos que aparecen mal restados en las imágenes de banda angosta sin continuo. De este modo, los círculos rojos señalan estrellas candidatas a RSG (Barbá et al., 2009) y la RSG clasificada por (Terlevich et al., 1996), los círculos azules identifican algunas de las estrellas WR conocidas (Drissen et al., 2008), el círculo verde marca el objeto clasificado como LBV-WR (Terlevich et al., 1996) y los círculos amarillos corresponden a estrellas sin ninguna mención en especial en la literatura y el cuadrado verde marca un objeto con emisión conspicua en $\mathrm{H}_{2}$.

candidatas a RSG (Barbá et al., 2009) y la RSG clasificada por (Terlevich et al., 1996), los círculos azules identifican algunas de las estrellas WR conocidas (Drissen et al., 2008), el círculo verde marca el objeto clasificado como LBV-WR (Terlevich et al., 1996), los círculos amarillos corresponden a estrellas sin ninguna mención en especial en la literatura y el cuadrado verde marca un objeto con emisión conspicua en $\mathrm{H}_{2}$, al cual se hará referencia más adelante. La resta de los objetos señalados ha dejado un residuo evidente en las imágenes de banda angosta al contrario de lo ocurrido con las otras miles de estrellas del campo las cuales se han logrado restar completamente. Esto se debe, en ocasiones, a que no se ha podido generar, mediante la convolución gaussiana y el factor de escala, una PSF semejante (para esos objetos en particular) en la imagen de banda angosta y la correspondiente imagen de banda ancha. Dicho efecto es esperable en el caso de las estrellas candidatas a RSG, ya que la mayoría de ellas están saturadas en las imágenes de Gemini-NIRI. Otros objetos, pueden tener emisión intrínseca importante en las imágenes de banda angosta, tal es el caso de las estrellas WR que presentan toda la serie del $\mathrm{H}$ en emisión intensa, junto con líneas de HeII.

\subsubsection{Resta del continuo de la imagen de $H_{\alpha}$ de HST-WFPC2}

En el trabajo publicado por O'Dell 2009 se detallan las correcciones y coeficientes necesarios para obtener la emisión de línea (sin continuo) calibrada en flujo a partir de imágenes adquiridas con HST-WFPC2. Según se detalla en dicha publicación, la ecuación general de la calibración tiene la forma: 


$$
S_{\text {linea }}=\frac{R_{\text {filtro }}}{K 1_{\text {filtro }}} \times\left(1-K 2_{\text {linea }} \frac{R_{\text {contamina }}}{R_{\text {filtro }}}-K 3_{\text {cont }} \frac{R_{547 M}}{R_{\text {filtro }}}\right)
$$

donde:

$S_{\text {linea }}$ es la imagen final de la línea de emisión (fotones $\mathrm{cm}^{-2} \mathrm{~s}^{-1} \mathrm{ster}^{-1}$ ).

$R_{\text {filtro }}$ es la imagen original de la línea de emisión (en $\mathrm{ADU} \mathrm{s}^{-1}$ ).

$R_{\text {contamina }}$ es la imagen de la principal línea contaminante la línea de emisión que se desea calibrar (en ADU s ${ }^{-1}$ ).

$R_{547 M}$ es la imagen que contiene la emisión del continuo (en $\mathrm{ADU} \mathrm{s}^{-1}$ ).

$K 1_{\text {filtro }}, K 2_{\text {linea }}$ y $K 3_{\text {cont }}$ son los coeficientes de calibración.

Para el caso de la línea de $H \alpha$ los valores utilizados fueron:

$R_{\text {filtro }} \rightarrow \mathrm{F} 656 \mathrm{~N}$, imagen correspondiente a la línea de $H \alpha$.

$R_{\text {contamina }} \rightarrow \mathrm{F} 658 \mathrm{~N}$, imagen correspondiente a la línea de [NII] en $\lambda 6583 \AA$.

$K 1_{\text {filtro }}=1.62$

$K 2_{\text {linea }}=0.038$

$K 3_{\text {cont }}=0.051$

La ecuación resultante aplicada sobre las imágenes mediante la tarea IMCALC es:

$$
S_{656}=\frac{F 656 N}{1,62} \times\left(1-0,038 \frac{F 658 N}{F 656 N}-0,051 \frac{F 547 M}{F 656 N}\right)
$$

En el panel izquierdo de la Figura 4.5 se muestra la imagen de $H \alpha$ original (F656N) y en el panel derecho la imagen $S_{656}$ ( $H \alpha$ con el continuo restado).

\subsubsection{Cociente de imágenes de Gemini-NIRI y HST-WFPC2}

Los cocientes de imágenes se realizan pixel a pixel. Esto implica que para realizar cocientes entre imágenes tomadas con distintos instrumentos no solo es necesario llevar ambas imágenes a una resolución espacial comparable (igualando el FWHM de los objetos puntuales), sino que también hay que imponerles a las imágenes el mismo número y tamaño de pixeles y alinearlas espacialmente de modo que el mismo pixel de coordenadas $(x, y)$ en ambas imágenes corresponda a las mismas coordenadas $(\alpha, \delta)$ en el campo.

Para llevar las imágenes a la misma resolución de imagen hay que convolucionar la imagen de HST-WFPC2 (de mayor resolución) con una gaussiana para lograr que el FWHM 'real' en ambas imágenes sea comparable, de modo similar a lo realizado previamente para las restas de continuo en las imágenes de Gemini-NIRI. Esto se realiza con la tarea GAUSs de la misma manera que se explicó en la Sección precedente, con la única (pero fundamental) diferencia que, en esta oportunidad, hay que tener en cuenta que los valores que se desean igualar son los FWHM de las imágenes medidos en segundos de arco (ya que los pixeles de ambas imágenes 


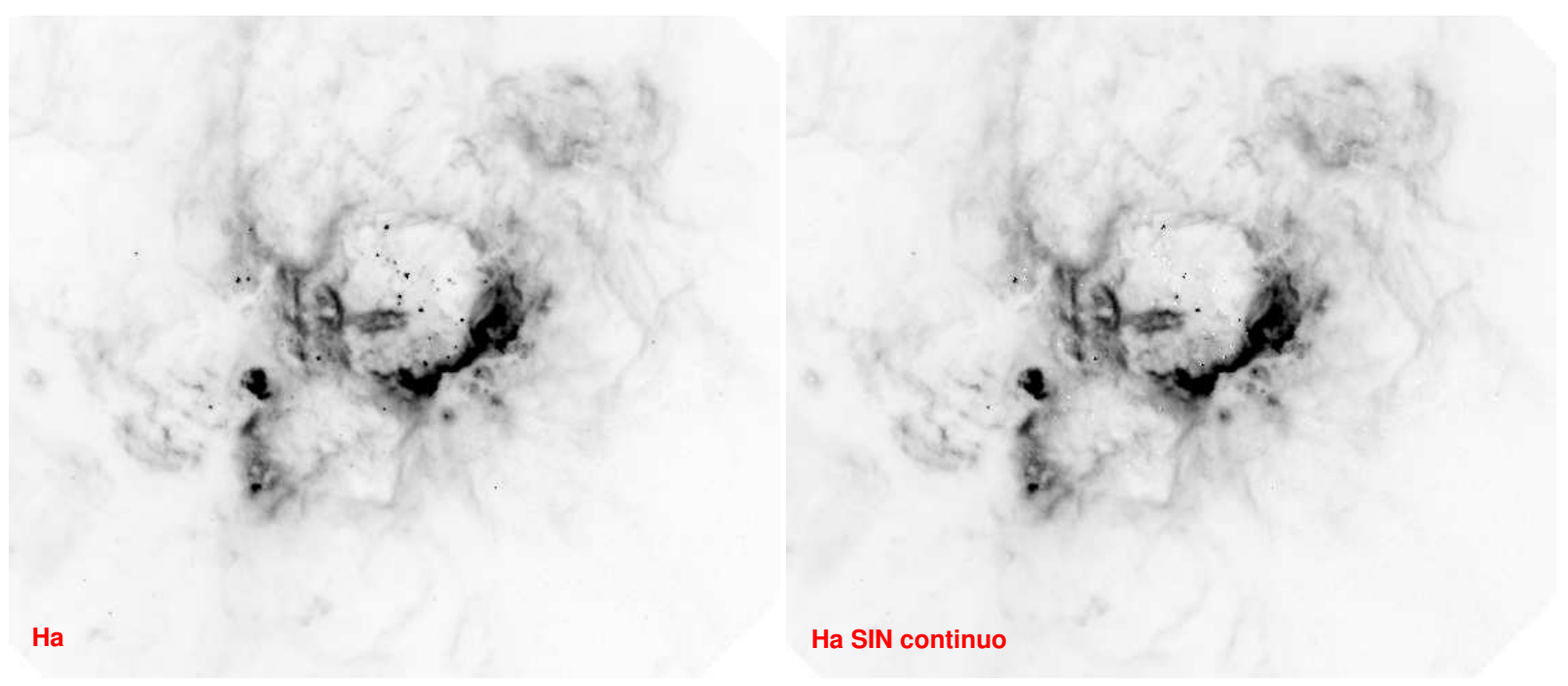

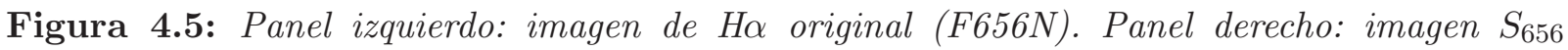

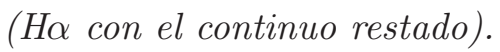

tienen distinta escala espacial). Una vez calculado $\sigma_{c o n v}$ en segundos de arco hay que transformarlo al número de pixeles correspondiente a la imagen que se desea convolucionar (dividiendo por la escala de los pixeles) para introducirlo en los parámetros de la tarea GAUSS.

La escala de los pixeles de las imágenes HST-WFPC2 (drizzled) ${ }^{2}$ es de $0.025^{\prime \prime} \mathrm{px}^{-1}$.

La escala de los pixeles de las imágenes de Gemini-NIRI es de $0.117^{\prime \prime} \mathrm{px}^{-1}$.

$\mathrm{FWHM}_{H S T(H \alpha)}=0.1^{\prime \prime}$

$\mathrm{FWHM}_{\text {Gemini }(B r \gamma)}=0.5^{\prime \prime}$

Se realizó la convolución de la imagen de HST por una Gaussiana de $\sigma_{\text {conv }}=0.2^{\prime \prime}$ (correspondiente a 8 pixeles en la imagen de HST).

Las imágenes de HST-WFPC2 tienen $3000 \times 3000$ pixeles $^{2}$ y cubren un área de $75 \times 75$ segundos de arco cuadrados, mientras que las imágenes de Gemini-NIRI cubren un área de $120 \times 120$ segundos de arco cuadrados con $1024 \times 1024$ pixeles $^{2}$. Es evidente que hay que aplicar un factor de escala para agrandar el tamaño de los pixeles de la imagen de HST-WFPC2 si se desea hacer un cociente pixel a pixel entre las imágenes de ambos telescopios. Esto se realiza mediante la tarea MAGNIFY que interpola imágenes aplicando el factor de magnificación ingresado, el cual va a estar dado por el cociente de las escalas de los pixeles en ambas imágenes, es decir: $0.117 / 0.025$. Es importante tener en cuenta que esta tarea debe correrse de modo que en la transformación de la imagen se conserve el flujo total de la imagen.

\footnotetext{
${ }^{2}$ El 'drizzling' es una técnica desarrollada para la cámara WFPC2 de HST, con el fin de mejorar la resolución espacial, limitada por el tamaño del pixel de su detector CCD. Ver http : //www.stsci.edu/hst/wfpc2/analysis/drizzle.html/
} 
Finalmente aprovechando que ambas imágenes tienen astrometría (de hecho la solución astrométrica para las imágenes de Gemini se calculó tomando como referencia estrellas del GSC de HST, según se describió en el Capítulo 2), se utilizó la tarea WREGISTER para registrar, es decir, para alinear pixel a pixel, la imagen de Gemini-NIRI respecto de la imagen de HST-WFPC2 (ya que esta última cubre un área menor que la de Gemini-NIRI).

Una vez llevadas las imágenes al mismo sistema de pixeles el cociente se calculó con la tarea IMCALC, considerando todos aquellos pixeles cuya señal fuera superior a 5 veces la desviación estándar del valor medio de fondo de cada imagen.

Las imágenes resultantes se muestran en la siguiente Sección junto con el análisis astrofísico derivado a partir de ellas y las otras imágenes detalladas al comienzo de este Capítulo.

\subsubsection{Mapas de extinción}

En la Figura 4.6 se muestran las tres imágenes generadas mediante los cocientes de imágenes de banda angosta. En el panel (a) se muestra el cociente de $B r \gamma / H \alpha$, en el panel (b) $P a \beta / H \alpha$ y en el panel (c) $\mathrm{Br} \gamma / \mathrm{Pa} \beta$. Como se mencionó en la nota al comienzo de este Capítulo, una vez calibrados en flujo, de estos cocientes se derivarán los mapas de extinción. Las imágenes de la Figura 4.6 cubren un área de $\sim 50^{\prime \prime} \times 50^{\prime \prime}$ correspondiente a la parte central del campo de NGC 604. La escala de colores utilizada en el despliegue de las imágenes es lineal y se muestra debajo del panel inferior, el color rojo señala las zonas donde el valor del cociente es mayor, es decir, las regiones de mayor extinción. A los tres mapas de cocientes se les ha aplicado un suavizado mediante la convolución con un núcleo gaussiano de $\sigma=3.0$ pixeles. Con el fin de no modificar arbitrariamente las imágenes, no se han enmascarado los residuos de objetos estelares mal restados, por lo tanto, es recomendable volver a la Figura 4.4 para identificarlos y familiarizarse con sus posiciones de modo de no confundirlos con estructuras 'verdaderas' en los mapas de extinción.

Si bien, como se observa en la Figura 4.6, los mapas muestran una estructura global (en gran escala) de extinción similar, al ser generados con distintas líneas (cuya intensidad de emisión varía y además son afectadas de forma levemente diferente por el polvo), presentarán información complementaria al estudiarlos en detalle.

Vale resaltar que si bien en la literatura varios autores ya habían generado mapas de extinción de NGC 604 (Relaño \& Kennicutt, 2009; Maíz-Apellániz et al., 2004; Bosch et al., 2002; Churchwell \& Goss, 1999), los presentados en este trabajo son los de mayor resolución espacial hasta el presente $\left(\sim 1^{\prime \prime}\right)$ por consiguiente permiten apreciar detalles de menor escala en la estructura nebular. 

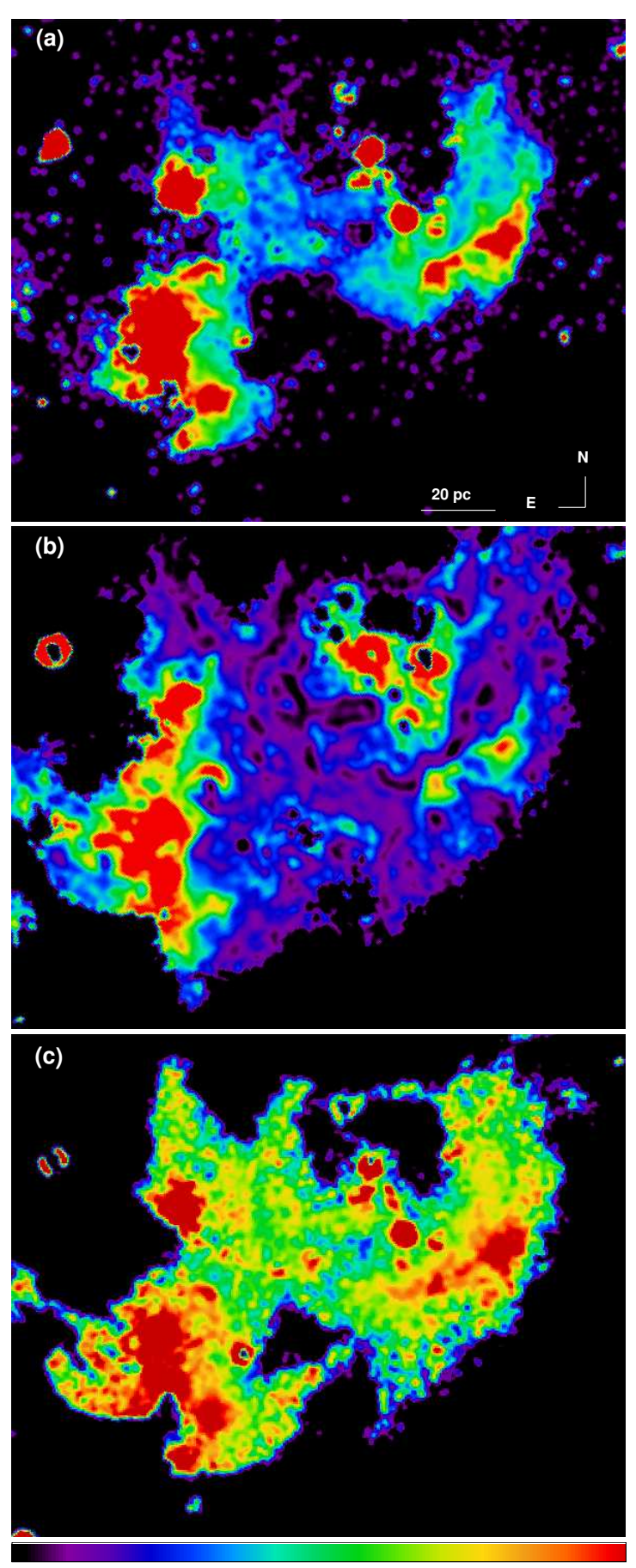

Figura 4.6: Tres mapas de extinción obtenidos a partir del cociente de las imágenes de banda

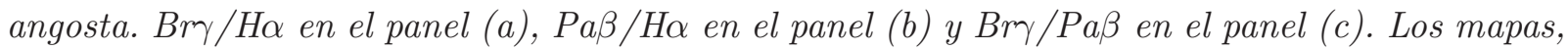
cubren un área de $\sim 50^{\prime \prime} \times 50^{\prime \prime}$ correspondiente a la parte central del campo de NGC604. El color rojo señala las zonas de mayor extinción. A los tres mapas de cocientes se les ha aplicado un suavizado mediante la convolución con un núcleo gaussiano de $\sigma=3.0$ pixeles. Con el fin de no modificar arbitrariamente las imágenes, no se han enmascarado los residuos de objetos estelares mal restados. 


\subsection{Los objetos con exceso IR en el contexto global de NGC 604}

En esta Sección se utilizará la imagen del cociente de $\mathrm{Br} \gamma / \mathrm{H \alpha}$ (como referencia de la extinción en la región), junto con imágenes en otros rangos espectrales, que trazan distintas componentes de medio interestelar (gas molecular con imágenes de $\mathrm{HCN}, \mathrm{CO}$ y $\mathrm{H}_{2} ; \mathrm{H}$ ionizado con imágenes del continuo de radio en $89 \mathrm{GHz}$ y $8.44 \mathrm{GHz}$ y polvo con imágenes de $8 \mu \mathrm{m}$ ) con el fin de caracterizar el medio en el cual se encuentran los objetos con exceso IR, reforzando la selección de los candidatos a MYSOs que se ha presentado en el Capítulo precedente.

La Figura 4.7 muestra seis paneles, en los cuales se han superpuesto sobre la imagen del cociente de $\mathrm{Br} \gamma / \mathrm{H \alpha}$, varios contornos de imágenes que trazan distintas componentes del medio interestelar. Es importante tener siempre presente cuando se realiza este tipo de superposiciones de imágenes y contornos, que lo que se observa en la imagen es la proyección en dos dimensiones de estructuras tridimensionales; por lo tanto, una correlación en proyección no necesariamente implica una correlación espacial (y mucho menos un vínculo físico). Es necesario medir otros parámetros físicos para establecer fehacientemente la existencia de vínculos físicos entre las componentes, como por ejemplo, velocidades radiales.

Los contornos de los paneles de la Figura 4.7 corresponden a imágenes que mapean distintas componentes del medio interestelar según se detalla a continuación:

- Panel 1 - Contornos de ${ }^{12} \mathrm{CO}$ : Los contornos de ${ }^{12} \mathrm{CO}$ marcan la ubicación de nubes moleculares relativamente difusas (con densidades del orden de $\mathrm{n}_{H_{2}} \sim 10^{2}-10^{4} \mathrm{~cm}^{-3}$ ).

- Panel 2 - Contornos de HCN: Los contornos de HCN mapean regiones de alta densidad en nubes moleculares, $n_{H_{2}}>10^{4} \mathrm{~cm}^{-3}$ (dos órdenes de magnitud mayores que las que mapea el ${ }^{12} \mathrm{CO}$ ). Dado que los núcleos moleculares donde se forman las estrellas masivas tienen una densidad de $\mathrm{n}_{H_{2}}=10^{4}-10^{6} \mathrm{~cm}^{-3}$ (Solomon et al., 1992), el HCN mapea regiones moleculares probablemente más vinculadas a la actividad de formación estelar que el CO. Es importante resaltar que de los contornos de HCN que se observan en esta imagen, el único máximo considerado como una detección confiable de HCN por Miura et al. (2010), es el que ha sido señalado con una flecha. Este máximo cumple con ser tres veces más intenso que el nivel de ruido de fondo y fue observado en dos canales de velocidades. Todos los otros contornos menores que se observan en la imagen, aunque aparecen bien definidos, fueron descartados por los autores como detecciones confiables debido a que sólo se observaron en uno de los canales de velocidades. Por consiguiente, cuando se hable de los contornos de HCN se estará haciendo referencia solamente al que se ha señalado con la flecha.

- Paneles 3 y 4 - Contornos de continuo de radio en $8.44 \mathrm{GHz}(3.6 \mathrm{~cm})$ y continuo de radio en $89 \mathrm{GHz}$ (3.36 mm): La emisión en el continuo de radio está dominada por 
emisión libre-libre del gas ionizado por los fotones UV emitidos por estrellas tempranas. Si bien ambas imágenes son interferométricas, la resolución espacial de $8.44 \mathrm{GHz}$ es de $\sim 2^{\prime \prime}$, mientras que la de $89 \mathrm{GHz}$ es de $\sim 7^{\prime \prime}$.

- Panel 5 - Contornos de Spitzer en $8 \mu \mathbf{m}$ : La emisión a $8 \mu \mathrm{m}$ está principalmente dominada por las moléculas de Hidrocarbonos Policíclicos Aromáticos $\left(\mathrm{PAH}^{3}\right)$. La emisión del polvo está asociada a las regiones de mayor extinción y, en particular, los PAH suelen estar vinculados con las regiones de fotodisociación (Draine, 2003).

- Panel 6 - Superposición de los objetos con exceso IR: En este panel se han superpuesto sobre la imagen del cociente de $B r \gamma / H \alpha$ los objetos con exceso IR encontrados en la fotometría de banda ancha. Como se describió en el Capítulo anterior, los objetos con exceso IR se encuentran mayoritariamente en la parte central de la región, delineando las zonas de mayor emisión nebular. En este panel se muestran con círculos blancos, los objetos que presentan exceso IR (pertenecientes a los grupos exclR $R_{1}$, exclR $R_{2}$ y exclR $R_{3}$ ) entre los cuales se han destacado con círculos negros los objetos con exceso IR extremo (del grupo exclR $\mathrm{R}_{3}$ ). Las posiciones de las dos fuentes que presentan emisión en $H_{2}$ se han señalado con dos estrellas negras.

\section{Observaciones y comentarios derivados de la Figura 4.7}

- Panel 1: Como se dijo anteriormente, los contornos de ${ }^{12} \mathrm{CO}$ delinean las zonas de extinción creciente y sus máximos se encuentran en regiones donde, debido probablemente a la extinción o a la escasez de $\mathrm{H}$ ionizado, la señal en nuestras imágenes no era lo suficientemente intensa como para generar el cociente. Dado que las observaciones interferométricas no son sensibles a estructuras de gran escala, para completar la información relativa a la ubicación de las nubes de $\mathrm{CO}$ del panel 1 , se ha incluido en el panel izquierdo de la Figura 4.8 (adaptada del trabajo de Maíz-Apellániz et al., 2004) una imagen con los contornos de ${ }^{12} \mathrm{CO}$ de Engargiola et al. (2003) superpuestos sobre la imagen de Ho (de HST-WFPC2). Si bien las imágenes de Engargiola et al. (2003) también son interferométricas, su resolución angular es menor, $13^{\prime \prime}$, por lo tanto muestran la estructura a gran escala del CO más completa, pudiéndose apreciar particularmente la ubicación y distribución de la nube molecular NMA-4 (siguiendo la nomenclatura de Miura et al., 2010).

- Comparando los paneles 1 y 2 se observa que el máximo de HCN se encuentra ligeramente desplazado hacia el norte respecto al máximo de CO de NMA-8; dicha observación fue hecha en el estudio de Miura et al. (2010) para el máximo de HCN mostrado derecho de la Figura 4.8 y para otro máximo detectado hacia el sur, que no entra en el campo aquí descripto. Los autores, establecieron mediante las velocidades de las nubes de CO y

\footnotetext{
${ }^{3}$ PAH: del acrónimo en inglés: 'Polycyclic Aromatic Hydrocarbon'.
} 

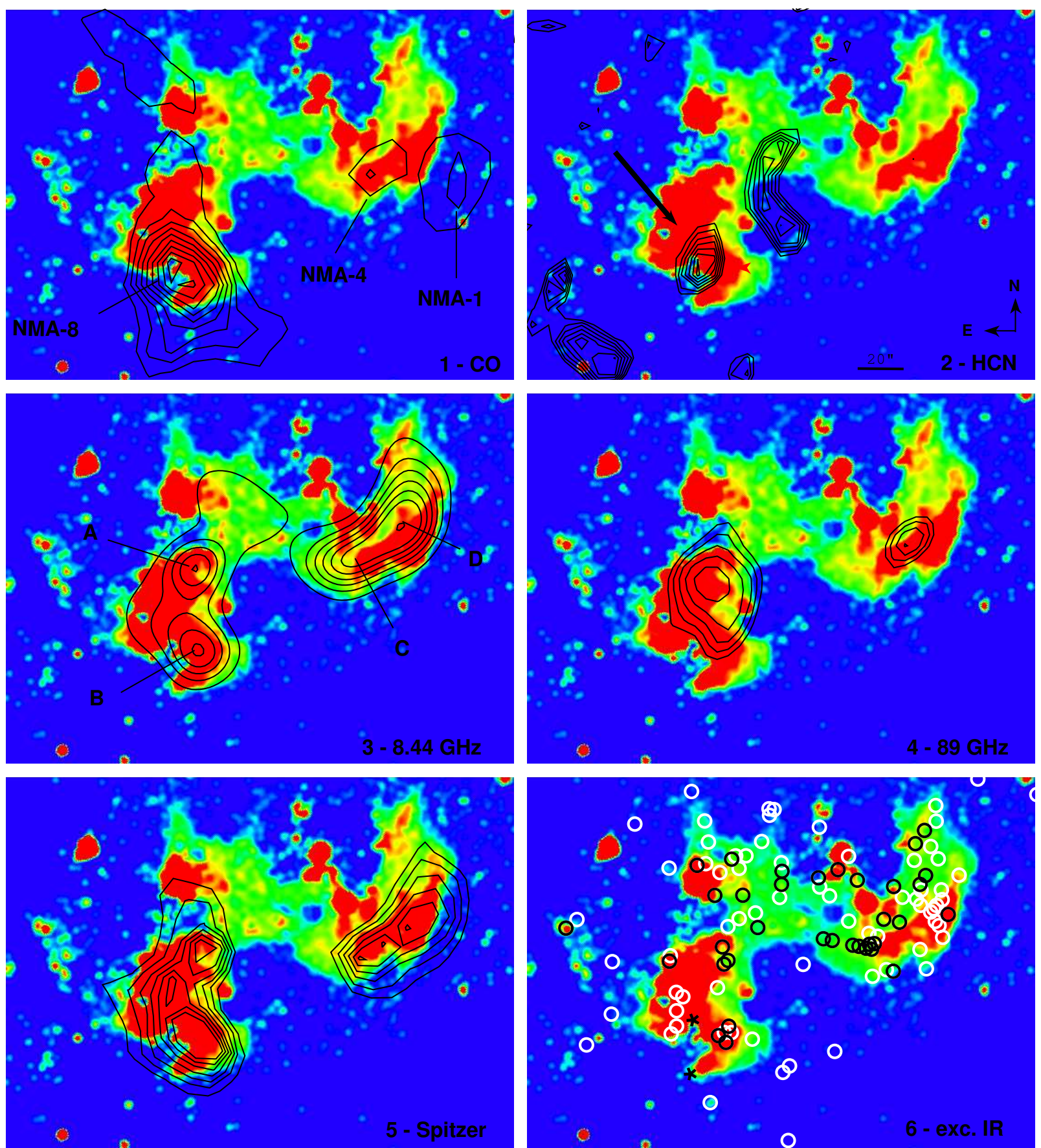

Figura 4.7: Seis paneles, en los cuales se han superpuesto sobre el mapa de extinción de Br $\gamma / H \alpha$, contornos de imágenes que mapean distintas componentes del medio interestelar. Como se indica en el margen inferior derecho de cada uno de los paneles, los contornos superpuestos corresponden a: panel 1, ${ }^{12} \mathrm{CO}$; panel 2, HCN; panel 3, continuo de radio en $8.44 \mathrm{GHz}$; panel 4, continuo de radio en $89 \mathrm{GHz}$; panel 5, contornos en $8 \mu \mathrm{m}$ de Spitzer; panel 6, objetos con exceso IR (círculos blancos), objetos con exceso IR extremo (círculos negros) y dos objetos con emisión en $\mathrm{H}_{2}$ (estrellas negras). 

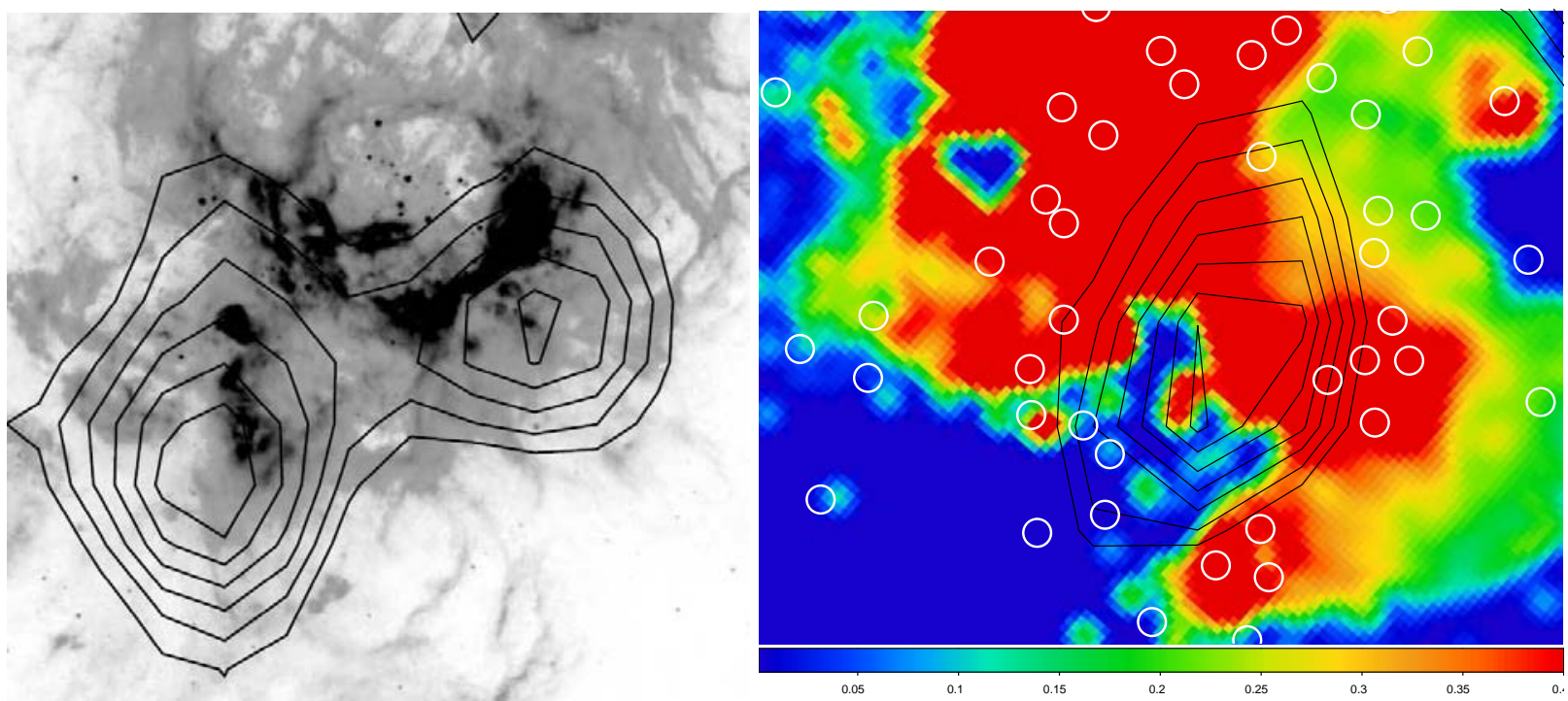

Figura 4.8: Panel izquierdo: Contornos de ${ }^{12} \mathrm{CO}$ de Engargiola et al. (2003) superpuestos sobre

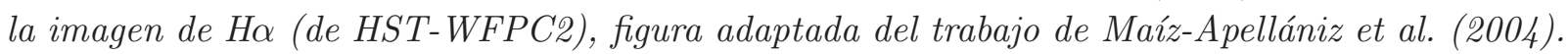
Panel derecho: Ampliación de la región donde se localiza el máximo de HCN (contornos negros). Se nota que en la posición de dicho máximo hay una región sin objetos detectados en la fotometría de JHKs (círculos blancos).

HCN, que las nubes de CO y HCN se encuentran asociadas entre sí, y por la ubicación relativa de las mismas, concluyen que las zonas densas donde se localiza actualmente la actividad de formación estelar, se encuentran ubicadas en el lado de las nubes moleculares más expuesto a la influencia del cúmulo central de estrellas masivas de NGC 604. Comparando la distribución de los objetos graficados en el panel 6 , con el máximo de $\mathrm{HCN}$, se nota que no se observan objetos con exceso IR donde se localiza el máximo $y$, considerando la distribución general de estrellas en esa región (mostrada en el panel derecho de la Figura 4.8) se nota que en la posición de dicho máximo hay una zona sin objetos detectados. Si bien esto puede deberse a una mera coincidencia, también podría ser explicado considerando que la nube de alta densidad mapeada por el HCN, se encuentra físicamente ubicada entre los objetos o en el camino de la visual, generando una extinción alta y localizada.

- Los continuos de radio en las dos frecuencias mostradas, $8.4 \mathrm{GHz}$ y $89 \mathrm{GHz}$ (en los paneles 3 y 4 , respectivamente), muestran una distribución similar, aunque se evidencian algunas diferencias. El máximo de la fuente I (siguiendo la nomenclatura de Miura et al., 2010) es prácticamente coincidente con el máximo en A (nomenclatura de Churchwell \& Goss, 1999) y el máximo de la fuente II se ubica en la región intermedia entre los máximos $C$ y $D$. Observando la distribución de objetos con exceso IR del panel 6, se nota que en las zonas correspondientes a los máximos $A, B, C$ y D del panel 3 , hay una 
densidad importante (y particularmente localizada para los nudos A, B y C) de objetos con exceso IR extremo (círculos negros). Como se mencionó en el Capítulo 3, el número de objetos con exceso IR que se localizan en dichas regiones es coincidente, en orden de magnitud, con el estimado por Churchwell \& Goss (1999). Otra observación relativa a los objetos con exceso IR, es que en las dos regiones de mayor extinción de la imagen se encuentran localizados grupos de objetos con exceso IR (círculos blancos en el panel 6) aunque no con exceso IR extremo. Esto se debe, posiblemente, a que en esas regiones la magnitud medida de los objetos tiene un error más grande (ya sea porque son más débiles a causa de la alta extinción, en particular en $J$ y $H$, y/o porque debido a la alta emisión nebular resulta difícil calcular un valor de cielo adecuado), de modo que los errores en el color $(H-K s)$ de estos objetos los dejan fuera de la clasificación de objetos con exceso IR extremo.

- El panel 5 muestra la distribución de la emisión dominada por las moléculas PAH. Se observa, como era previsible, que los contornos de $8 \mu \mathrm{m}$, mapean exactamente las regiones de mayor extinción, poniendo en evidencia la presencia de polvo en esos lugares.

- En el panel 6, también se han señalado con estrellas negras, la ubicación de los dos objetos con emisión en $H_{2}$ descriptos en la última Sección de este Capítulo.

\subsection{Emisión en $B r \gamma$ y $K_{s}$}

Siguiendo con los argumentos para confirmar (a nivel general) la selección de objetos candidatos a MYSOs presentada en esta Tesis, se estudió la relación entre la emisión en $K s, B r \gamma$ y el exceso IR de las fuentes puntuales.

Una de las posibles explicaciones a los excesos en $(H-K s)$ observados en el análisis de las imágenes de banda ancha, es la presencia de objetos con líneas de emisión intensa en $\mathrm{Br} \gamma$. Para ilustrar este punto se ha incluido en la Figura 4.9 una imagen tomada de Campbell \& Terlevich (1984) donde los autores han graficado en el diagrama CC las posiciones de: un cuerpo negro a $\mathrm{T}=42500 \mathrm{~K}(\mathrm{HBB})$, emisión gaseosa con líneas de recombinación (GE) y estrellas supergigantes rojas de tipo M (RSG), conectadas por trazos que marcan la ubicación de objetos según porcentajes de mezcla entre estas tres componentes. En este diagrama puede observarse que la emisión puramente gaseosa GE (la que correspondería un nudo de emisión nebular) se ubica en la región ocupada por los objetos con exceso IR (comparar este diagrama con los diagramas CC presentados en el Capítulo 3).

Ahora bien, si el exceso IR de los objetos fuera causado principalmente debido a la presencia de emisión intensa en $B r \gamma$, se esperaría que dichos objetos se encuentren ubicados por encima 


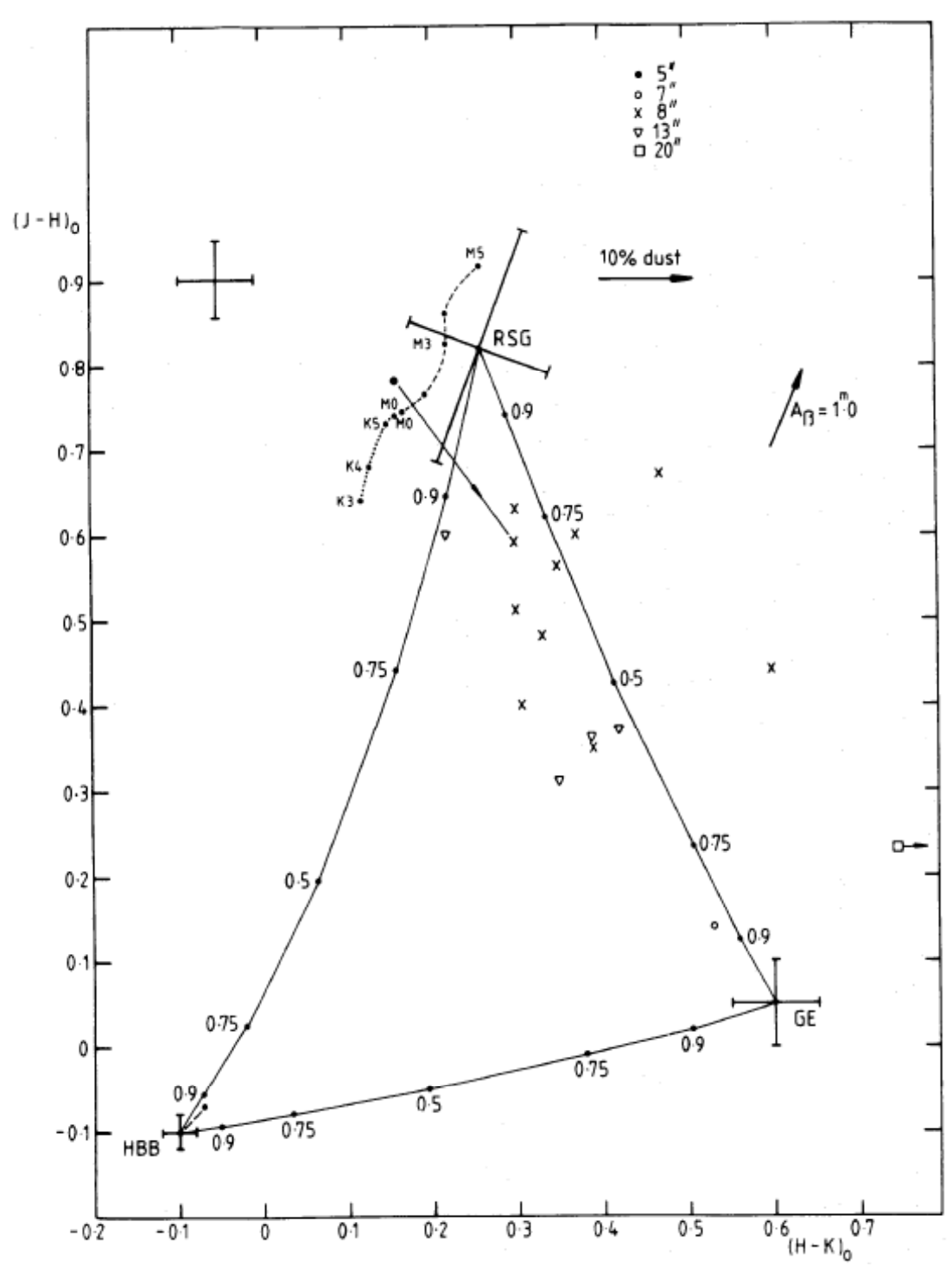

Figura 4.9: Diagrama $C C$ con las posiciones de un cuerpo negro a $T=42500 \mathrm{~K}$ (HBB), emisión gaseosa con líneas de recombinación (GE) y estrellas supergigantes rojas de tipo $M(R S G)$, conectadas por trazos que marcan la ubicación de objetos con porcentajes de mezcla entre estas tres componentes. La emisión puramente gaseosa se ubica en la región que corresponde a los objetos con exceso IR. Imagen tomada de Campbell \&3 Terlevich (1984). 
de un valor medio de $(K s-B r \gamma),(K s-B r \gamma)_{\text {medio }}$, dado por el valor medio del color de los objetos que no presentan exceso IR. Esto se deriva conceptualmente del hecho de que la incidencia de la línea de emisión en la magnitud del filtro de banda angosta $(B r \gamma)$ es proporcionalmente mayor que la incidencia de esa misma línea en el filtro de banda ancha $(K s)$.

La afirmación previa puede derivarse matemáticamente mediante el siguiente planteo senciIlo: Se considera el caso simplificado en que el flujo de un objeto con línea de emisión se puede modelizar como el flujo de continuo $F_{c}$ (constante en el rango de longitudes de onda del filtro de banda ancha) más el flujo de la línea superpuesto $f_{l}$ (cuyo ancho es suficientemente pequeño como para despreciar efectos de transmisión del filtro ${ }^{4}$ ).

La ecuación de flujo medido está dada por:

$$
F=\int F_{\lambda} T_{\lambda} R_{\lambda} d \lambda
$$

donde $T_{\lambda}$ la transmisión del filtro y $R_{\lambda}$ otros factores como emisividad del telescopio, transmisión atmosférica, etc (dichos factores los consideramos iguales para ambos filtros).

La resta de las magnitudes para un objeto sin línea de emisión es:

$$
\left(K_{s}-B r \gamma\right)=-2,5 \times \log \left(\frac{F_{c} A}{F_{c} a}\right) \therefore\left(K_{s}-B r \gamma\right)=-2,5 \times \log \left(\frac{A}{a}\right)
$$

donde $A$ y a son las áreas (rango de longitud de onda $\times$ porcentaje de transmisión) de las curvas de transmisión de los filtros de $K s$ y $B r \gamma$, respectivamente.

Planteando la misma ecuación para objetos con línea de emisión en $B r \gamma$ sumada a un nivel de continuo constante se obtiene:

$$
\begin{gathered}
\left(K_{s}-B r \gamma\right)_{l}=-2,5 \times \log \left(\frac{F_{c} A \times\left(1+f_{l} / F_{c} A\right)}{F_{c} a \times\left(1+f_{l} / F_{c} a\right)}\right) \\
\left(K_{s}-B r \gamma\right)_{l}=-2,5 \times \log \left(\frac{F_{c} A}{F_{c} a}\right)-2,5 \times \log \left(\frac{\left(1+f_{l} / F_{c} A\right)}{\left(1+f_{l} / F_{c} a\right)}\right) \\
\left(K_{s}-B r \gamma\right)_{l}=-2,5 \times \log \left(\frac{A}{a}\right)-2,5 \times \log \left(\frac{\left(1+f_{l} / F_{c} A\right)}{\left(1+f_{l} / F_{c} a\right)}\right)
\end{gathered}
$$

\footnotetext{
${ }^{4}$ Dicha suposición se puede justificar si se tiene en cuenta que los valores medidos son del orden de $\sim 1 \AA$ o menores.
} 


$$
\left(K_{s}-B r \gamma\right)_{l}=\left(K_{s}-B r \gamma\right)+C t e
$$

donde $C t e=-2,5 \times \log \left(\frac{\left(1+f_{l} / F_{c} A\right)}{\left(1+f_{l} / F_{c} a\right)}\right)$

La constante $C$ te $>0$ ya que $0<\frac{\left(1+f_{l} / F_{c} A\right)}{\left(1+f_{l} / F_{c} a\right)}<<1$, de lo que resulta que el valor de $(K s-B r \gamma)$ con línea de emisión en $B r \gamma,\left(K_{s}-B r \gamma\right)_{l}$, es el valor de $\left(K_{s}-B r \gamma\right)$ sin línea más una constante positva.

Se calculó la fotometría PSF para los objetos de la imagen de $B r \gamma$; sólo 727 objetos fueron detectados y medidos en esta imagen (considerando para la detección, al igual que para los filtros de banda ancha, un nivel de $5 \sigma$ por encima de la emisión de fondo). De estos objetos un total de 570 tienen magnitudes detectadas en $\mathrm{JH} K s$, los restantes 157 objetos detectados en $B r \gamma$ corresponden a nudos de emisión puramente nebular sin contraparte medible en el continuo (es decir, en las imágenes de banda ancha). De las 570 fuentes con magnitudes en $B r \gamma$ y JH $K s$, 42 presentan exceso IR, de las cuales 27 cumplen la condición de que la distancia a la línea de enrojecimiento es mayor que la incerteza en el color, es decir, que presentan exceso IR confiable (exclR $\operatorname{exclR}_{1}$ siguiendo la notación utilizada en el Capítulo precedente) y 15 presentan exceso IR aunque no cumplen esta condición.

La Figura 4.10 muestra el diagrama de $(K s-B r \gamma)$ en función de la magnitud $K s$ (panel superior) y el diagrama CC (panel inferior) para los mismos objetos. En código de colores (el mismo para ambos diagramas) se han identificado con rojo los objetos que presentan exceso IR confiable y con azul los 15 objetos con exceso IR dentro de la incerteza en el color. Como puede observarse en el diagrama de $(K s-B r \gamma)$, los objetos se distribuyen alrededor de una recta de valor $(K s-B r \gamma)_{\text {medio }}=-4.7$ y la dispersión de los puntos, como es esperable, crece con la magnitud. En dicho gráfico los objetos con exceso IR no muestran una distribución especial ni una tendencia marcada a tomar valores de $(K s-B r \gamma)$ mayores, como sería el caso si los objetos tuvieran exceso IR producido pura y exclusivamente por una línea de emisión en $B r \gamma$ muy intensa. A partir de este resultado puede argumentarse que, para la mayoría de los objetos con exceso IR que se han identificado, dicho exceso no proviene únicamente de una emisión extremadamente intensa de la línea de $B r \gamma$, sino que es causado posiblemente por la línea de $B r \gamma$ junto con otras contribuciones de: i) líneas en la banda $K s$ (como pueden ser las líneas de las cabezas de banda de CO) y/o ii) un aumento en la emisión de continuo, como ocurre con los objetos de Clase 0 (ver ejemplos en la Sección 1.5 en el Capítulo 1).

La Figura 4.11 se ha incluido para ilustrar este último caso. La imagen fue tomada de Tachihara et al. (2007). El gráfico muestra datos fotométricos de la fuente Lupus 3MMS, un objeto 

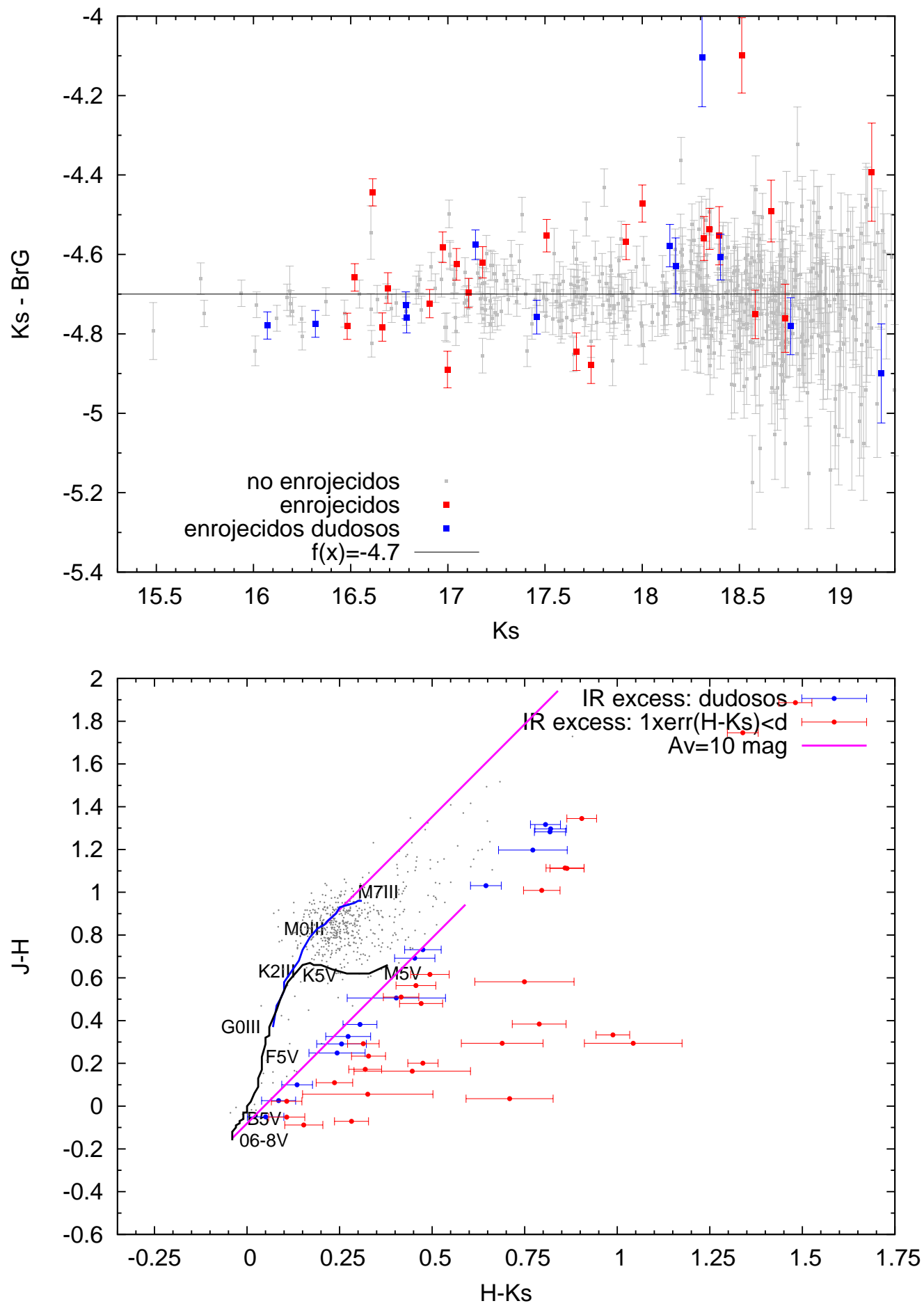

Figura 4.10: Gráfico de (Ks-Bry) en función de la magnitud Ks (panel superior) y diagrama $C C$ (panel inferior) para los objetos con fotometría PSF en JHK y Br $\gamma$. En código de colores se han identificado con rojo los objetos que presentan exceso IR confiable y con azul los 15 objetos con exceso IR dentro de la incerteza en el color. 


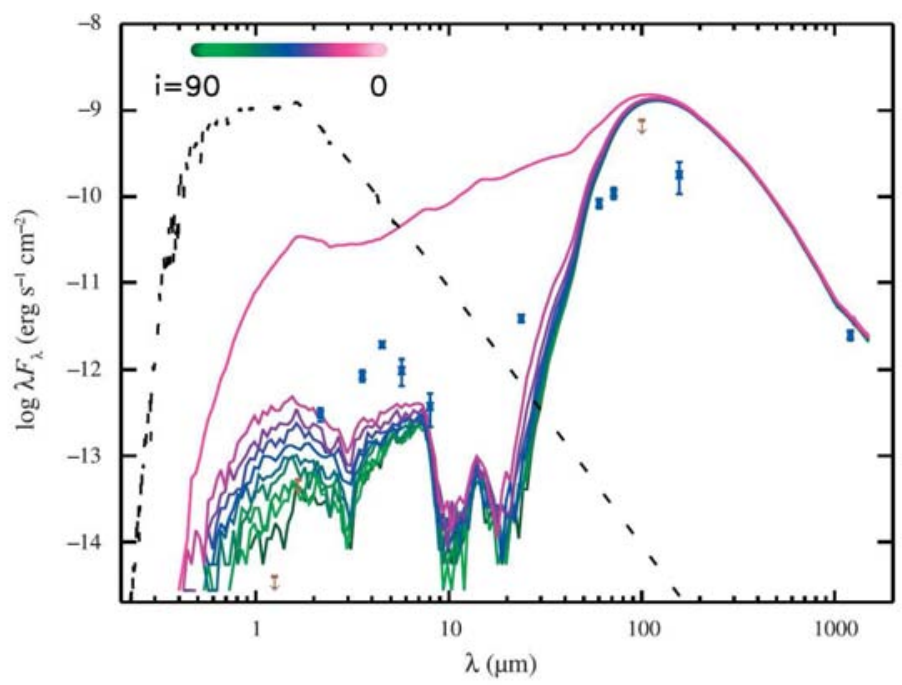

Figura 4.11: Figura tomada de Tachihara et al. (2007). Se han graficado datos fotométricos de la fuente Lupus 3MMS, un objeto clasificado de Clase 0, con las curvas de SED modeladas para un objeto de Clase 0 visto desde diferentes ángulos según la escala de colores en el margen superior izquierdo. La línea de puntos corresponde al objeto central cuya temperatura efectiva se estima en T sim $4000 \mathrm{~K}$.

clasificado de Clase 0 , con las curvas de distribución espectral de energía (SED ${ }^{5}$ ) modeladas para un objeto de Clase 0 visto desde diferentes ángulos según la escala de colores en el margen superior izquierdo. La línea de puntos corresponde al objeto central cuya temperatura efectiva se estima en $\mathrm{T} \sim 4000 \mathrm{~K}$.

El hecho de que los objetos no sean mayoritariamente identificables con emisión en $B r \gamma$ también indica que la tasa de incidencia de nudos de emisión nebular en el diagrama CC es muy baja. Los objetos masivos del tipo de los clasificados como Clase 0 parecen ser los más probables en el caso de los candidatos MYSOs identificados en este estudio.

\subsection{Objetos con emisión de $H_{2}$}

Como se mencionó previamente hay dos objetos que resultan particularmente interesantes porque presentan emisión relativamente conspicua en $H_{2}$. En la Figura 4.12 se muestra la ubicación de dichos objetos (señalados con las letras A y B) en el campo de NGC 604. El panel izquierdo corresponde a la imagen de banda ancha en el filtro $J$, mientras que en el panel derecho, los objetos se muestran sobre la imagen de $\mathrm{H}_{2}-\mathrm{Br} \gamma$ (usando $\mathrm{Br} \gamma$ como continuo para la imagen de $\mathrm{H}_{2}$ ). La escala de colores en ambas imágenes se está invertida, de modo que los

\footnotetext{
${ }^{5}$ SED: del acrónimo en inglés de 'Spectral Energy Distribution'.
} 

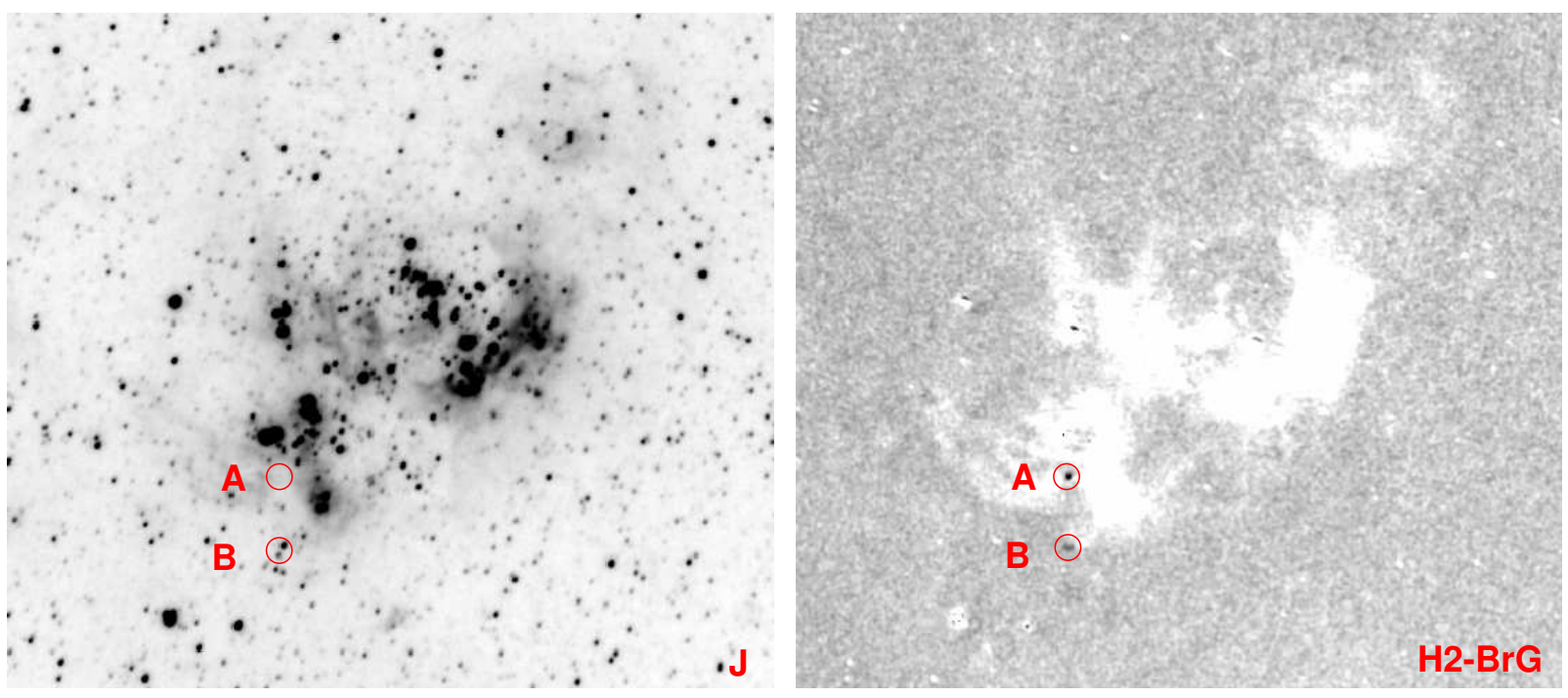

Figura 4.12: Panel izquierdo: imagen de la banda ancha J. Panel derecho: imagen de $\mathrm{H}_{2}-\mathrm{Br} \gamma$. Los objetos con emisión en $\mathrm{H}_{2}$ se han señalado con las letras $A$ y $B$. La escala de colores en ambas imágenes está invertida, de modo que los objetos más brillantes se ven más oscuros.

objetos más brillantes se ven más oscuros.

En la Figura 4.13, se muestra una ampliación del área que contiene a ambos objetos en las imágenes de distintos filtros, según se indica en las inscripciones en el margen inferior derecho de cada uno de los paneles. El panel 5, es el mapa de extinción, en el que se han superpuesto los contornos de ${ }^{12} \mathrm{CO}$; allí se observa que la posición proyectada de ambos objetos los sitúa en la nube molecular de $\mathrm{CO}$, en los alrededores del máximo. Ninguno de los dos objetos presenta emisión en $H \alpha$ (como se observa en el panel 7); esto podría ser un efecto de la extinción ya que del conjunto de imágenes que se utilizaron en este estudio, la imagen del filtro del $H \alpha$ (que corresponde al rango de longitudes de onda más cortas) es la más afectada por la extinción.

\section{El objeto A}

Este objeto prácticamente no se observa en la banda $J$ ni $P a \beta$ (paneles 1 y 4 , respectivamente), pero se va haciendo progresivamente más intenso en $H$ (panel 2) y es un objeto brillante en la banda $K s$ (panel 3). En el panel 5 se nota que el objeto A se encuentra en una región de alta extinción, con lo cual, su ausencia en $J$ y progresivo brillo creciente hacia $K s$ podría ser efecto de la extinción. Observando los paneles 6 y 9 , se deduce que el objeto A, es muy brillante en $K s$ debido, en parte, a la contribución de la emisión en la línea de $H_{2}$ pero no de $B r \gamma$ (ya que prácticamente no se lo observa en el panel 6). En síntesis, el objeto A presenta una clara emisión en la línea de $H_{2}$ (de hecho, en los paneles 8 y 9 aparece casi como un objeto puntual, considerando el FWHM de las imágenes de $H_{2}$ ) y se encuentra situado, al menos en proyección, dentro de una nube de material molecular y alta extinción. 

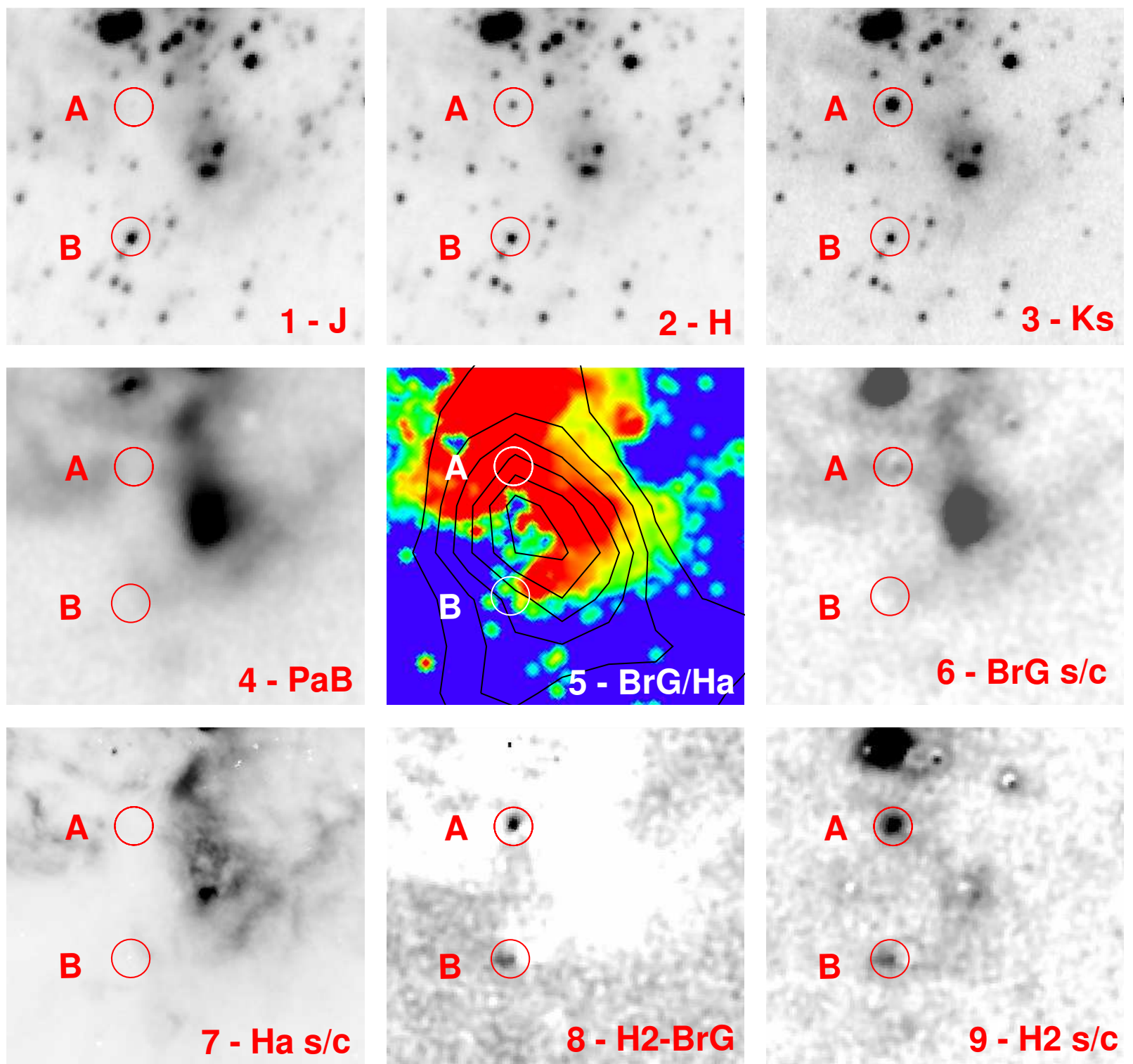

Figura 4.13: Ampliación del área que contiene a los objetos con emisión en $\mathrm{H}_{2}$ (señalados con las letras $A$ y $B$ ) en las imágenes de distintos filtros, según se indica en las inscripciones en el margen inferior derecho de cada uno de los paneles. 


\section{El objeto B}

El objeto $B$ aparece como una emisión más difusa (menos intensa y más extendida) que el objeto $\mathrm{A}$ en las imágenes de $H_{2}$ (paneles 8 y 9). El mapa de extinción del panel 5 no brinda información respecto al nivel de extinción correspondiente a su ubicación (aunque en esa región probablemente la extinción sea importante). Coincidente con la ubicación del objeto $B$, en los paneles de las imágenes de banda ancha $J, H$ y $K s$ aparece un objeto 'estelar' (sólo es posible observar una emisión más extendida en la banda $K s$ si se disminuye exageradamente el rango dinámico de la imagen, mostrando principalmente los valores de intensidad más bajos). El objeto $\mathrm{B}$ no se observa en $P a \beta, B r \gamma$, ni en $H \alpha$.

Como se mencionó anteriormente, la emisión de $H_{2}$ en el NIR, ya sea en la transición vibracional $\mathrm{v}=1-0 \mathrm{~S}(1)(\lambda=2.12 \mu \mathrm{m}) \circ \mathrm{v}=2-1 \mathrm{~S}(2)(\lambda=2.25 \mu \mathrm{m})$ correspondiente a la banda de $\mathrm{H}_{2}$ aquí presentada, tiene lugar en nubes moleculares de alta densidad, con temperaturas $\mathrm{T} \gtrsim 2000 \mathrm{~K}$, y puede ser provocada básicamente por dos mecanismos:

- Por colisiones en frentes de choques, generalmente asociados con eyecciones de materia ('outflows') en fuentes estelares jóvenes. La emisión de $H_{2}$ vinculada a eyecciones de materia es frecuente observada en 'outflows' de $\mathrm{CO}$ de objetos estelares jóvenes, principalmente de masa intermedia y baja, aunque también existen varios estudios que señalan la presencia de 'outflows' en los que se observa emisión de $H_{2}$ vinculados a estrellas masivas jóvenes, en formación (Kumar et al., 2002; Martín-Hernández et al., 2008).

- En regiones de formación estelar masiva la emisión de $H_{2}$ puede producirse en la región de fotodisociación $\left(\mathrm{PDR}^{6}\right)$ y hay reportes observacionales de PDRs delineadas por los contornos de $\mathrm{H}_{2}$ en otras regiones de formación estelar masiva (Rubio et al., 2000, 1998). En estos casos la emisión suele ser extendida.

La imagen de $\mathrm{H}_{2}$ de Gemini-NIRI presenta muy bajo brillo superficial, pero en el panel 9 puede notarse una especie de línea en dos tramos, que va de $A$ hacia $B$ pasando por el nudo de emisión en $B r \gamma$ (ver panel 6); esa estructura podría marcar el limite de la región de fotodisociación, sin embargo con la imagen de $\mathrm{H}_{2}$ con que contamos no puede asegurarse que esa estructura que parece verse sea realmente la PDR. La emisión de los objetos A y B es comparativamente más conspicua que la de la dicha estructura.

En la literatura sobre NGC 604 no hay datos ni estudios relativos a estos dos objetos en particular. Las observaciones utilizadas en este trabajo han servido para localizar e identificar por primera vez objetos de estas características en la región. Nuevas observaciones, específicamente focalizadas en el estudio de las fuentes A y B, son necesarias para revelar su verdadera naturaleza y estudiar sus características físicas, junto con las del medio en el que están inmersas.

\footnotetext{
${ }^{6}$ PDR: del acrónimo en inglés de 'Photodissociation Region'.
} 


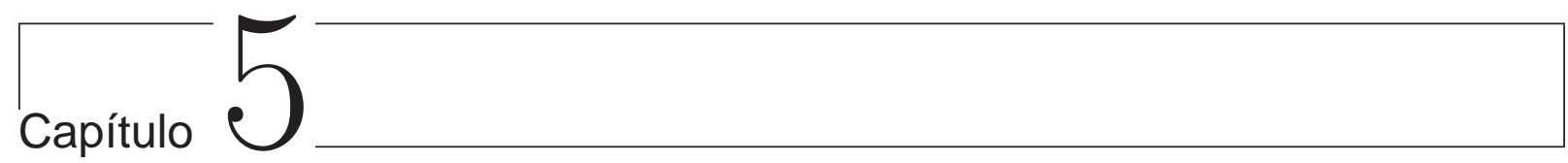

\section{Trabajo a futuro}

En este Capítulo se resumen los nuevos proyectos que se fueron generando a partir de los resultados derivados durante el desarro del estudio de esta Tesis.

Las Secciones que contiene el presente Capítulo son: - Propuesta presentada para GeminiNIFS: una propuesta de observación concreta, realizada para observar con Gemini-NIFS pequeños campos de NGC 604 con varias fuentes clasificadas como candidatos a MYSOs; • Futura propuesta para observar las fuentes $A$ y B: una propuesta para observar con Gemini-GNIRS los objetos $\mathrm{A}$ y $\mathrm{B}$, que presentan emisión conspicua en $\mathrm{H}_{2} ; \bullet$ Nueva información obtenida a partir de datos ya existentes: un proyecto para seguir estudiando la población estelar de NGC 604, con datos derivados de las imágenes de Gemini-NIRI y HST; • Fracción de objetos con exceso IR en GHRs: un proyecto para continuar con el estudio de la fracción de objetos con exceso IR en otras GHRs, con observaciones existentes o con nuevas observaciones cuando sea necesario. 



\subsection{Propuesta presentada para Gemini-NIFS}

\section{Spectrocopic study of massive young stellar objects within NGC 604 giant star- forming region.}

Con el fin de certificar la naturaleza de las fuentes seleccionadas como candidatas a MYSOs en el presente estudio, se ha presentado una nueva propuesta de observación en Gemini-Norte. Dicha propuesta, es parte de un proyecto que consiste en la observación de campos específicos dentro de la región de NGC 604 donde se ubican grupos de fuentes candidatas a MYSOs. El objetivo del proyecto es estudiar y caracterizar en detalle a cada uno de los objetos candidatos a MYSO individualmente, junto con el medio interestelar de su entorno cercano. La propuesta fue presentada para el semestre 2010B, y ha sido posicionada en Banda-1, de modo que los datos de uno de los campos estarán disponibles a partir de comienzos de 2011.

El proyecto del cual forma parte la mencionada propuesta consta de cinco campos de NGC 604 seleccionados para ser observados con NIFS (Near Infrared Integral Field Spectrometer), en la banda K. Como indica su nombre, NIFS es un espectrógrafo de campo integrado. Las imágenes tomadas con NIFS son en realidad un cubo de datos; es decir, las imágenes de NIFS están compuestas por una imagen bidimensional cuya tercer dimensión está dada por espectros obtenidos en la posición de cada uno de los pixeles. El campo cubierto por NIFS es de $3^{\prime \prime} \times 3^{\prime \prime}$. La escala de los pixeles es de $0.04^{\prime \prime}$ en la dirección de la 'ranura' y de $0.103^{\prime \prime}$ en dirección perpendicular a la misma, con lo cual se obtiene una resolución espacial de $\sim 0.1^{\prime \prime}$ (con corrección de óptica adaptativa). Las observaciones serán realizadas en la banda $\mathrm{K}$, que cubre un rango espectral entre $\lambda=1.99-2.40 \mu \mathrm{m}$. Como se ha mencionado, el rango espectral cubierto por la banda $\mathrm{K}$ es particularmente importante para estudiar la naturaleza y el estadio evolutivo de los objetos masivos jóvenes, debido a la presencia de una gran cantidad de líneas de emisión características de los MYSOs, como Hi, HeII, MgII, FeII, $\mathrm{H}_{2}$ y las cabezas de banda de CO (Bik et al., 2006). La resolución espectral alcanzada en esta banda, $R=5290$, es suficiente para resolver las líneas espectrales que se espera observar, permitiendo identificar fehacientemente las líneas de emisión de los candidatos a MYSOs. Por otro lado, debido a la cobertura espacial de NIFS, será posible inferir propiedades relativas a la cinemática del gas del medio interestelar circundante de los objetos.

Los cinco campos elegidos para ser observados con Gemini-NIFS se muestran en la imagen de la Figura 5.1. En dicha imagen se han graficado las regiones seleccionadas con cuadrados que representan el campo de visión de NIFS a escala, y con la orientación elegida para cada región. Los objetos candidatos a MYSOs identificados en el presente estudio, se han señalado con cuadrados amarillos pequeños. 


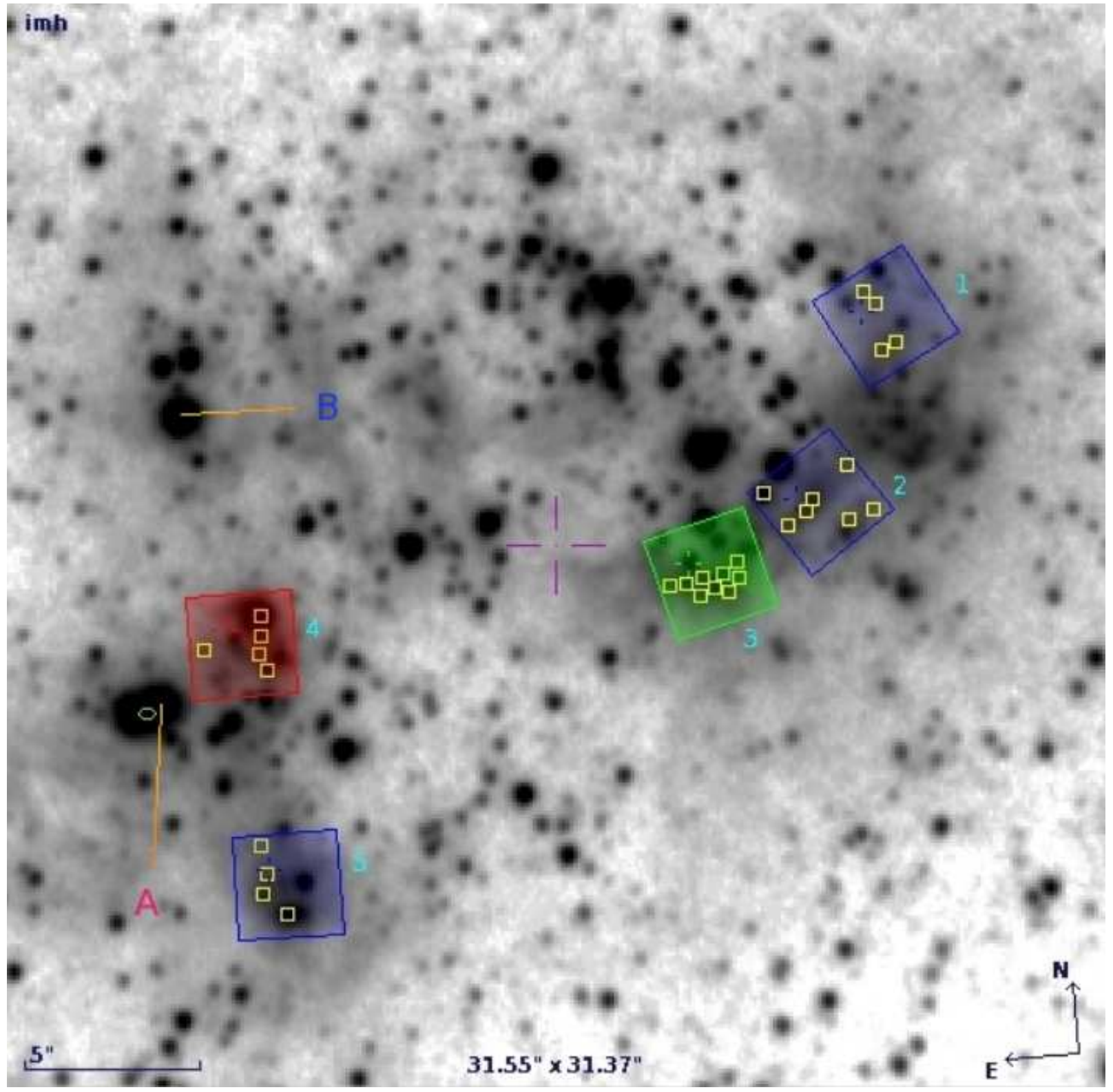

Figura 5.1: Campos seleccionados para ser observados con Gemini-NIFS. Las regiones seleccionadas corresponden a los cuadrados que representan el campo de visión de NIFS a escala, con la orientación elegida para cada región. Los objetos candidatos a MYSOs identificados en el presente estudio, se han señalado con cuadrados amarillos pequeños. 
En la propuesta presentada para el semestre 2010B, se observará el campo_4 (marcado con un cuadrado rojo en la imagen de la Figura 5.1).

Las observaciones se harán utilizando ALTAIR (ALTtitude conjugate Adaptive optics for the InfraRed) con lente de campo y OIWFS (On-Instrument WaveFront Sensor). ALTAIR es el sistema de óptica adaptable de Gemini-Norte. EI OIWFS realiza pequeñas correcciones para compensar por posibles movimientos entre NIFS y ALTAIR. La lente de campo de ALTAIR se utiliza para lograr que la PSF sea más estable en todo el campo y es particularmente beneficioso su uso en la presente propuesta, porque se observarán objetos diseminados en todo el campo de NIFS que se encuentran a más de 5" de separación de la estrella guía.

Fue necesario realizar la propuesta de observación utilizando una estrella guía laser (LGS) debido a que ALTAIR requiere, para efectuar una buena corrección, una estrella guía con una magnitud $\mathrm{R}<\sim 12$ mag (en el óptico) ubicada en un radio $<25^{\prime \prime}$ del campo seleccionado. Dadas las características de la región observada, la mayoría de los objetos brillantes en el óptico, se encuentran inmersos en regiones oscurecidas por la presencia de polvo en el medio interestelar de modo que no fue posible encontrar un objeto en ese rango de magnitudes en el óptico. De hecho también ha resultado difícil encontrar un objeto apropiado para utilizar como guía para OIWFC el cual requiere un objeto con magnitud $\mathrm{K}<\sim 15.5$ mag en un anillo circular entre $12^{\prime \prime}$ y $25^{\prime \prime}$ de radio.

La imagen de la Figura 5.2 muestra la configuración final para la propuesta de observación presentada. Se han superpuesto sobre la imagen de la banda $K s$ de NIRI la ubicación del campo_4 y la posición de las estrellas guía para ALTAIR-AOIWFS y NIFS-OIWFS. En la imagen también se muestra la región viñeteada por el OIWFS, cuyos contornos son las líneas rojas en forma de herradura que rodean el campo_4. Los círculos rojos y celestes representan los radios accesibles para la ubicación de las estrellas guía de AOIWFS y OIWFS. Esta imagen fue generada durante la Fase II con la herramienta OT (Observing Tool) de Gemini.

A continuación se describen algunos de detalles específicos de la propuesta de observación para Gemini-NIFS junto con los motivos que justifican las condiciones requeridas.

Las condiciones observacionales, se dan en porcentajes (percentiles más específicamente) de ocurrencia de la propiedad que representan. Todas la definiciones y valores de referencia se encuentran en la página del observatorio Gemini (http://www.gemini.edu/node/10781) Las condiciones observacionales requeridas en la propuesta presentada son:

- IQ $20 \%$-ile. IQ hace referencia a la calidad de la imagen requerida (IQ: Image Quality). IQ $20 \%$ indica que se requiere la mejor calidad de imagen posible (y la menos frecuente). Por ejemplo, IQ $20 \%$ en la banda K con OIWFS, implica que una fuente en el zenit tendrá un diámetro al $50 \%$ de la energía no mayor a $0.3^{\prime \prime}$. 


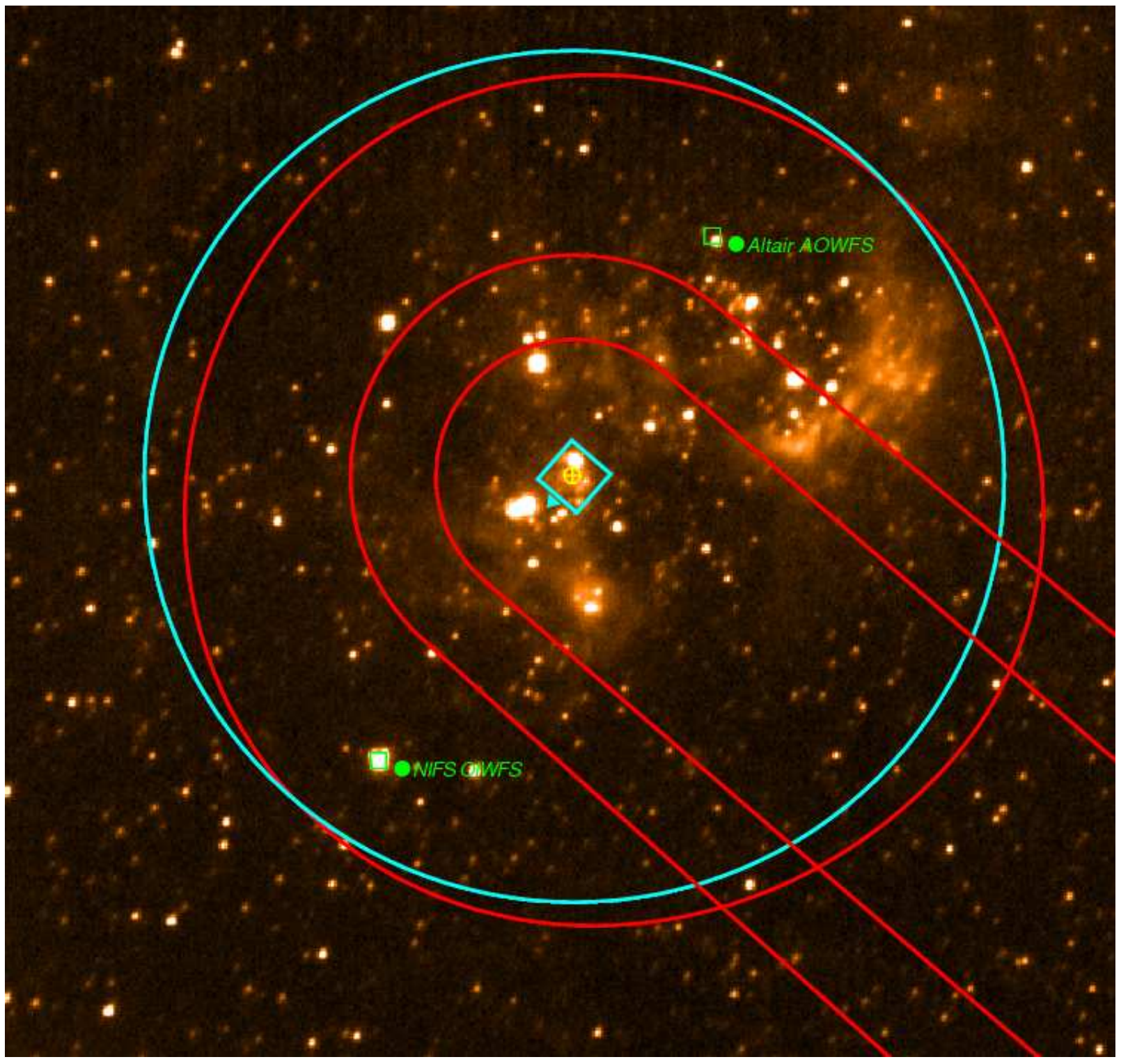

Figura 5.2: Configuración final para propuesta de observación presentada. Se han superpuesto sobre la imagen de la banda Ks de NIRI la ubicación del campo_4 y la posición de las estrellas guías para ALTAIR-AOIWFS y NIFS-OIWFS. La región viñeteada por el OIWFS (cuyos contornos se trazaron con líneas rojas, en forma de herradura rodeando el campo_4). Los cículos rojos y celestes representan los radios accesibles para la ubicación de las estrellas guías de AOIWFC y OIWFS. Esta imagen fue generada durante la Fase II con la herramienta OT (Observing Tool) de Gemini. 
- CC $50 \%$-ile. CC hace referencia a la transparencia del cielo relativa a la presencia de nubes (CC: Cloud Cover). CC 50 \%-ile implica una calidad de cielo fotométrica, es decir, cielo sin nubes y en el cual sea posible mantener un flujo estable. La propagación del láser utilizado para la LGS puede realizarse sólo en condiciones fotométricas y de buen seeing. Las condiciones tanto de IQ como de CC están fuertemente restringidas por el uso de ALTAIR junto con la LGS. Por otro lado, durante las pruebas realizadas con la calculadora de tiempo de integración (ITC ${ }^{1}$ )de NIFS se ha observado que al cambiar el CC de $20 \%$ a $50 \%$ la relación $\mathrm{S} / \mathrm{N}$ del espectro final obtenido no cambia significativamente, pero al pasar de CC $50 \%$ a CC $70 \%$ la relación S/N cae más de un $30 \%$.

- WV any. WV hace referencia a la transparencia del cielo relativa a la cantidad de vapor de agua presente en la atmósfera (WV: Water Vapor). En el NIR, el vapor de agua afecta principalmente a las regiones entre las bandas $\mathrm{J}, \mathrm{H}$ y $\mathrm{K}$, sin embargo su efecto no es importante dentro de cada una de las bandas en sí mismas, ya que fueron diseñadas justamente teniendo en cuenta este efecto, entre otros (ver detalles en el Capítulo 1).

- SB any. SB hace referencia a la emisión de fondo del cielo (SB: Sky Background). Como se detalló en el Capítulo 1, en el NIR, la emisión de fondo del cielo está dominada por las líneas de emisión de airglow y, en particular en la banda K, también por la contribución de la emisión térmica de $\mathrm{CH}_{4}$ y $\mathrm{H}_{2} \mathrm{O}$. Estas emisiones se modelizaron para ser incluidas en la ITC, junto con otras contribuciones a la emisión de fondo como la emisión zodiacal, la emisión térmica atmosférica, etc. Durante los ensayos realizados con la ITC (sobre el espectro de un objeto estelar joven de una magnitud $K \sim 19.0$ ) se observó que la relación $\mathrm{S} / \mathrm{N}$ del espectro final obtenido, no se ve fuertemente afectada por la elección del SB; el factor dominante en dicha relación es el ruido poissoniano propio de la señal. De modo que el SB se ha dejado en 'any' para maximizar la posibilidad de que la observación se realice.

- $\mathrm{AM}<1.2$. En AM se define al máximo valor para la masa de aire (airmass) hasta el cual es posible realizar la observación. Obviamente la masa de aire afecta la transparencia del cielo, el brillo de fondo y la calidad de imagen, de modo que se ha limitado hasta un valor máximo de $\mathrm{AM}=1.2$ con el fin de obtener la mejor calidad de imagen posible.

La propuesta requiere una secuencia de 7 exposiciones, de 600 segundos cada una, en el campo_4. Intercaladas con las observaciones del campo_4, se deben realizar 4 exposiciones, de 600 segundos cada una, en un campo de cielo. Es decir, 4200 segundos de exposición en la fuente y 2400 segundos en el campo del cielo. Con lo cual, se espera obtener una relación $\mathrm{S} / \mathrm{N}>5$ para el continuo de los espectros finales de los objetos. Tanto la secuencia del campo_4 como la secuencia del campo de cielo, incluyen un pequeño patrón de dithering rectangular (de $0.15^{\prime \prime}$ en una dirección y $0.06^{\prime \prime}$ en la dirección perpendicular a la anterior) con el fin de facilitar

\footnotetext{
${ }^{1}$ ITC: del acrónimo en inglés de 'Integration Time Calculator'.
} 
la corrección por pixeles malos y rayos cósmicos.

Los datos del campo_4 serán reducidos y analizados apenas estén disponibles. De este modo, teniendo en cuenta la experiencia adquirida en la observación de esta primera propuesta, se planea presentar para 2011B, y en los sucesivos semestres, las propuestas para la observación de los campos restantes, hasta obtener los datos de las cinco regiones seleccionadas.

\subsection{Futura propuesta para observar las fuentes A y B}

Se planea también presentar una propuesta de observación para el semestre 2012B con Gemini-GNIRS, con el fin de realizar una observación focalizada en el estudio de los objetos A y B que presentan emisión en la línea de $H_{2}$. Una vez obtenidos y analizados los datos GNIRS, es posible que se realice una nueva propuesta con Gemini-NIFS, ya que NIFS constituye también para estos objetos una buena opción instrumental si se desea obtener información acerca de la emisión del objeto central y el material de los alrededores, para comprobar la existencia de posibles 'outflows'.

\subsection{Nueva información obtenida a partir de datos ya existentes}

Con el fin de completar la caracterización de los objetos del cúmulo de NGC 604 se planea generar la distribución espectral de energía de los objetos mediante la complementación de los datos en el infrarrojo cercano de Gemini con los surgidos de la fotometría del HST en el UV, el óptico y el IR. A partir de la SED es posible derivar parámetros físicos de los objetos utilizando la herramienta CHORIZOS (Maíz-Apellániz, 2004) cuyo desempeño se optimiza cuanto mayor es la cobertura espectral de la fotometría disponible.

Este estudio se desarrollará en dos fases; durante la primer se establecerá la correlación entre los objetos detectados independientemente mediante observaciones con distintos instrumentos, de manera de generar un sistema fotométrico libre de sesgos a partir del cual se pueda obtener la SED de los objetos. En la segunda fase, se realizará el análisis que permitirá derivar temperaturas y gravedades de las estrellas, junto con una determinación del mapa de enrojecimiento sufrido por las estrellas del cúmulo ionizante. Para esto se hará uso de la herramienta CHORIZOS, el cual es un código desarrollado para comparar datos fotométricos con modelos de SEDs. CHORIZOS, permite seleccionar la familia de SED y escoger la forma en que se realizará el ajuste de cada parámetro, incluyendo la opción de limitar su rango de variación. El código calcula entonces la bondad del ajuste para todos los rangos especificados, lo cual permite identificar soluciones múltiples y evaluar la matriz de correlación para los parámetros derivados de una 
solución única.

\subsection{Fracción de objetos con exceso IR en GHRs}

Se planea ir completando el diagrama de fracción de objetos con exceso IR vs. edad del cúmulo central, con los puntos correspondientes a otras GHRs, en un principio, con información existente en la literatura y observaciones en las bandas JHKL, disponibles en las bases de datos públicas de distintos telescopios. La idea es comprobar si las GHRs presentan alguna tendencia en su ubicación en dicho diagrama, con respecto a la regresión encontrada por Haisch y colaboradores para las regiones de formación estelar galáctica. Este estudio también podría brindar información concerniente a la existencia de discos alrededor de estrellas masivas en formación. 

$\Gamma_{\text {Capítulo }}$

\section{Síntesis de resultados y consideraciones finales}

En este Capítulo se expone una síntesis de los resultados que se han obtenido en el estudio desarrollado para la Tesis de Doctorado presentada y su relevancia.

NGC 604 ha sido ampliamente estudiada, se la ha observado con una enorme variedad de instrumentos en todos los rangos del espectro y se han aplicado infinidad de técnicas y modelos para el análisis de los datos. Sin embargo, en el compendio de los estudios previos realizado en el Capítulo 1, se habrá notado que hay más trabajos dedicados al estudio de la componente gaseosa que de la componente estelar, y entre los estudios dedicados a la componente estelar hay más información relativa a los objetos evolucionados de NGC 604 que a los objetos más jóvenes. De hecho, con excepción del artículo publicado por Barbá et al. (2009) que, como se mencionó, forma parte del mismo proyecto que el estudio aquí presentado, no hay todavía otros trabajos específicamente abocados a caracterizar la nueva generación estelar de NGC 604. En las publicaciones previas que abordan este tema, los autores infieren la presencia de una nueva generación estelar de un modo más indirecto, en general, a través de las medidas obtenidas de la emisión de nebular (ionizada o molecular) a gran escala. En este estudio se han detectado los 'objetos individuales' que presentan exceso IR y se han seleccionado aquellos cuya ubicación en el campo fuera consistente con un escenario de formación estelar. Habiendo hecho esto se puede decir que en tales coordenadas es donde se encuentran los objetos que conforman la nueva generación de estrellas de NGC 604. Por lo tanto, el catálogo de candidatas aquí presentado constituye una lista detallada de los objetos que merecen ser analizados con más detalle.

A continuación se expone una síntesis del trabajo realizado y los resultados obtenidos en la presente Tesis. 


\section{- Se han detectado y seleccionado 72 objetos candidatos a MYSOs}

Se estudió la distribución espacial de dichos objetos en el campo de NGC 604. Los objetos candidatos a MYSOs se encuentran mayoritariamente localizados en el arco de alta densidad de medio molecular tibio (el cual presenta condiciones de densidad y temperatura apropiadas para propiciar y mantener procesos de formación estelar masiva actual).

\section{- Se calculó la fracción total de objetos con exceso IR en el cúmulo de NGC 604} La fracción de objetos con exceso IR obtenida para NGC 604 se evaluó en el contexto de los datos derivados para regiones de formación estelar galácticas. El resultado indica que NGC 604 presenta una fracción de objetos con exceso IR sustancialmente alta para la edad del cúmulo, en relación a la regreción obtenida a partir de los datos de regiones galácticas. Este resultado genera, naturalmente, el planteo respecto a una posible tendencia de las poblaciones de las GHRs a tener una fracción de objetos con exceso IR más elevada que las regiones de formación estelar galácticas, y si así fuera cuáles son los motivos. Para poder comenzar a responder a la primer cuestión es necesario, en principio, incluir en el diagrama de fracción de objetos con exceso IR versus edad del cúmulo, otras GHRs para corroborar si tal tendencia existe.

\section{- Se detectaron, por primera vez en la región, dos objetos con emisión en $H_{2}$} Dicha emisión, no es extendida (a gran escala) sino que se encuentra localizada. La emisión de $\mathrm{H}_{2}$ es frecuentemente observada asociada a eyecciones de materia en estrellas en formación de masa intermedia-baja. En regiones de formación estelar masiva dicha emisión puede producirse en la región de fotodisociación y hay reportes observacionales sobre este efecto en otras regiones de formación estelar. En estos casos la emisión suele ser extendida. También es posible que se trate de emisión de un disco-envoltura de acreción alrededor del objeto masivo central, los reportes de estas detecciones son aún poco frecuentes y dichos objetos podrían constituir una evidencia observacional para agregar a la discusión relativa a la existencia de los discos de acreción alrededor de MYSOs. En cualquier caso estos objetos resultan interesantes y se necesitan nuevas observaciones para definir la causa de la emisión detectada en $H_{2}$.

\section{- Se generaron imágenes que mapean la extinción en la región}

A partir del cociente de las imágenes de banda angosta de Gemini-NIRI y de $\mathrm{H} \alpha$ (de HST-WFPC2). Estos mapas junto con imágenes en otros rangos espectrales, que trazan distintas componentes de medio interestelar ( $\mathrm{HCN}, \mathrm{CO}$, continuo de radio en $89 \mathrm{GHz}$ y $8.44 \mathrm{GHz}, 8 \mu \mathrm{m}$ ) se utilizaron para caracterizar el medio en el cual se encuentran los objetos con exceso IR reforzando la selección de los candidatos a MYSOs aquí presentados. Una vez calibrados en flujo, los mapas de extinción serán los de mejor resolución espacial $\left(\sim 1^{\prime \prime}\right)$ obtenidos hasta el presente en NGC 604. Esto permitirá obtener la extinción en estructuras de pequeña escala lo cual es importante en NGC 604 dada la complejidad de 
la distribución de la componente nebular, incluyendo el polvo, en la región.

\section{La gran mayoría de los objetos identificados como candidatos a MYSOs son estrellas masivas en formación}

Es una afirmación que puede formularse a partir del estudio llevado a cabo en esta Tesis. Dado que una vez detectados los objetos con exceso IR, la selección de los que resultaron ser candidatos a MYSOs se realizó mediante un análisis del medio interestelar en los alrededores de la ubicación de los objetos. Para este análisis se han utilizado los datos derivados en esta Tesis (los cocientes de imágenes que trazan la atenuación del medio interestelar) y también se han incluido una variedad de datos y resultados de estudios previos. Los MYSOs seleccionados se encuentran en regiones donde hay fuertes indicios que indican la presencia (o su posibilidad) de procesos de formación estelar masiva actual. Es posible que no absolutamente todos los objetos seleccionados como candidatos a MYSOs a partir de su exceso IR sean efectivamente MYSOs; ya que los datos fotométricos utilizados no son suficientes para asegurar, con toda certeza, la naturaleza de las fuentes inmersas detectadas.

\section{Objetos puntuales versus objetos singulares}

Se ha utilizado la expresión 'objetos individuales' para hacer referencia a los candidatos a MYSOs encontrados; sin embargo, se ha tenido siempre presente que dichos 'objetos individuales' pueden llegar a ser pequeños grupos no resueltos. No hay que olvidar que se han estudiado objetos a casi 1 megaparsec de distancia. Se ha mencionado anteriormente que a la distancia de NGC 604, 1" equivale a $\sim 4.1$ pc y el FWHM de los objetos en las imágenes de banda ancha es $\sim 0.35^{\prime \prime}$. Por su carácter disperso y extendido, la distribución estelar de NGC 604 permite la resolución espacial de gran parte de su población estelar. Claramente este estudio no hubiera sido posible en una estructura similar a la de R136. La posibilidad de que en nuevas observaciones algunos de los candidatos a MYSOs, 'objetos individuales', resulten finalmente ser un grupo de objetos no resuelto hacen el dato igualmente interesante, pues en ese caso, los objetos estarán suficientemente próximos entre sí y su observación puede brindar información sobre temas tales como multiplicidad inicial, fragmentación y estructura de los núcleos densos, interacción entre objetos en formación (no sólo con el medio interestelar), etc.

\section{Saber cuáles son y dónde están los MYSOs en NGC 604}

Sobre la importancia de saber cuáles son y dónde están los MYSOs brevemente se puede argumentar que, por ser objetos en la fase previa a las estrellas masivas, evidentemente los MYSOs son poco frecuentes y su estadio en la fase de MYSO tiene una escala de tiempos extremadamente corta. Además, los MYSOs se encuentran en regiones en las cuales no es fácil su detección (regiones relativamente distantes, inmersos en nubes de gas y polvo con absorción considerable y en un entorno de estrellas de alta masa cuyo medio interestelar presenta emisión nebular intensa y variable). Los MYSOs eluden las observaciones y en consecuencia se conoce poco sobre ellos. Se ha mencionado previamente en esta Tesis que aun hay cuestiones básicas 
sin resolver relativas a la formación de estrellas de alta masa, formación de discos de acreción, IMF, multiplicidad inicial, fragmentación de la nube molecular, son algunos de los temas cuyas respuestas requieren de más datos observacionales. Aun en aquellos temas cuyas respuestas requieran desarrollos teóricos y simulaciones computacionales los datos observacionales son necesarios para definir las condiciones iniciales y de contorno de los modelos teóricos. En virtud de lo dicho, la cantidad de candidatos a MYSOs que se han identificado en este estudio (y sus coordenadas), se presenta como una fuente importante y rica de datos disponibles mediante observaciones más específicas apuntadas en esas direcciones.

\section{Nuevas imágenes en camino}

El estudio realizado en esta Tesis ha abierto camino para continuar con el estudio de varios objetos individuales en la reagión. En el Capítulo anterior se describió detalladamente la primera propuesta de observación presentada en Gemini-Norte, para realizar un estudio de espectroscopía de campo integrado, con NIFS, de una de las regiones en la cual se localizan algunos de los objetos candidatos a MYSOs. Se han seleccionado otros cuatro campos para ser observados. Las propuestas se presentarán una vez que se verifique la profundidad y calidad de los datos obtenidos en la primera observación, con el fin de replantear la estrategia de observación si fuera necesario, ya que se está observando en el límite de sensibilidad del instrumental. Se estima que las imágenes serán adquiridas en febrero de 2011. También se mencionó la idea de generar otra nueva propuesta de observación en Gemini, para el próximo semestre, 2012B, con el fin de estudiar los objetos con emisión de $H_{2}$ detectados en NGC 604 con las imágenes de Gemini-NIRI. Y posiblemente, se realicen nuevas proyectos para continuar con el estudio de fracciones de objetos con exceso IR en otras GHRs. 


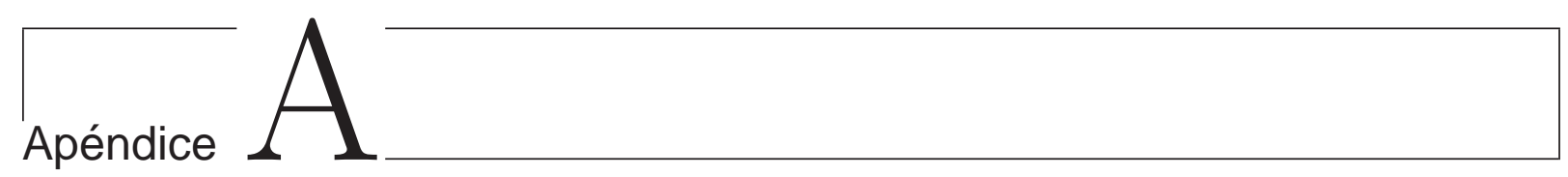

\section{Glosario}

\section{A.1. Acrónimos y abreviaciones}

- ADU: Analog-to-digital Unit

- ALTAIR: ALTtitude conjugate Adaptive optics for the InfraRed

- CCD: del acrónimo en inglés de 'Charge-Coupled Device' (dispositivo de carga acoplada)

- CC: abreviación para color-color usada en la expresión 'diagrama color-color'

- CM: abreviación para color-magnitud usada en la expresión 'diagrama color-magnitud'

- DQ: plano de calidad de dato (Data Quality) en las imágenes MEF

- $e^{-1}$ : electrón

- FIR: del acrónimo en inglés de 'Far Infrared' (infrarrojo lejano)

- FWHM: del acrónimo de 'Full-Width Half-Maximum' (ancho a mitad de potencia)

- GHR: del acrónimo en inglés de 'Giant HiI Region' (región HiI gigante)

- GNIRS:

- HST: Hubble Space Telescope

- IMF: del acrónimo en inglés de 'Initial Mass Function' (función inicial de masa)

- IMS: del acrónimo en inglés de 'Interstellar Medium' (medio interestelar)

- ITC: del acrónimo en inglés de 'Integration Time Calculator' (calculadora de tiempo de integración) 
- LGS: del acrónimo en inglés de 'Laser Guide Star' (estrella guía laser)

- LMC: del acrónimo en inglés de 'Large Magellanic Cloud' (Nube Mayor de Magallanes)

- LVB: del acrónimo en inglés de 'Luminous Blue Variable' (variable luminosa azul)

- MEF: del acrónimo en inglés de 'Multi-extention Fits file' (archivo Fits multiextensión)

- MIR: del acrónimo en inglés de 'Mid Infrared' (infrarrojo medio)

- MKO: Mauna Kea Observatories

- MS: del acrónimo en inglés de 'Main Sequence' (secuencia principal)

- MYSO: del acrónimo en inglés de 'Massive Young Stellar Object' (objeto estelar masivo joven)

- MW: del acrónimo en inglés de 'Milky Way' (Vía Láctea)

- NIFS: Near Infrared Integral Field Spectrometer

- NIR: del acrónimo en inglés de 'Near Infrared' (infrarrojo cercano)

- NIRI: Near Infrared Imager and Spectrometer

- OIWFS: On-Instrument Wave Front Sensor

- PAH: del acrónimo en inglés: 'Polycyclic Aromatic Hydrocarbon' (Hidrocarbonos Policíclicos Aromáticos)

- PDR: del acrónimo en inglés de 'Photodissociation Region' (región de fotodisociación).

- PSF: acronym from Point Spread Function

- RSG: del acrónimo en inglés de 'Red Super Giant' (supergigante roja)

- SED: del acrónimo en inglés de 'Spectral Energy Distribution' (distribución espectral de energía)

- SMC: del acrónimo en inglés de 'Small Magellanic Cloud' (Nube Menor de Magallanes)

- SNR: del acrónimo en inglés de 'Supernova Remnant' (remanente de supernova)

- S/N: Signal to noise relation (relación señal ruido)

- SOBA: del acrónimo en inglés de 'Scaled OB Association' (asociación OB escalada)

- SSC: del acrónimo en inglés de 'Super Star Cluster' (supercúmulos estelares) 
- UCHII: del acrónimo en inglés de 'Ultra Compact HiI Region' (región HII ultracompacta)

- VAR: plano de varianza en las imágenes MEF

- WCS: World Coordinate System

- WR: estrellas Wolf-Rayet

- ZAMS: del acrónimo en inglés de 'Zero Age Main Sequence' (secuencia principal de edad cero) 



\section{Agradecimientos}

Comencé y terminé esta Tesis porque tuve la suerte de estar rodeada de personas excepcionales, con quienes comparto mi vida y a quienes les voy a estar siempre agradecida.

A Guille porque desde 2005 venís acompañándome y guiándome en este camino, dejándome espacio para que camine a mi modo (a veces muy lento :)) y elija por donde quiero ir, con paciencia casi infinita y una predisposición que internamente te agradecí en cada momento, enseñándome como si conversaras con un par, siempre dispuesto a responder todas las preguntas (y ya sabemos como es eso: algunas preguntas pueden ser interesantes, muchas preguntas son tontas y muchas, muchas preguntas son repetidas ...), siempre valorando el trabajo y el esfuerzo, siempre celebrando cada avance, siempre con palabras de apoyo (pocas palabras y oportunas ... muy tuyo Guille :)) ... gracias Guille por todo, fue muy bueno tenerte como director de todas las tesis y sin dudas será muy bueno seguir trabajando juntos en estas nuevas etapas ... me gustaría que mis alumnos (si tengo algún día) sientan por mí lo que yo siento por vos.

A Rodolfo, por contagiarme con sus explosiones de entusiasmo astronómico y ... de entusiasmo en general ... hay tantas cosas que me explicaste tan rápido que voy entendiendo de a poco, pasados ya algunos años.

A Nidia, por que veo en vos una pasión que me fascina y me inspira ... por las conversaciones que hemos tenido ... a las cuales recurro con frecuencia.

A Edu, por las noches de Eta Carinae en el reflector ... allí fue donde comenzó a tomar forma mi sueño por observar, y luego también por las tardes de los viernes en tu oficina ... largas charlas y mates con mucha azúcar.

A Fede por el tiempo y el esfuerzo que dedicaste a ayudarme con todo lo que tiene que ver con las computadoras, siempre con excelente predisposición ... te lo agradecí en cada oportunidad pero quiero decirlo explícitamente en este momento.

También quisiera agradecer a los jurados que leyeron mi Tesis de Doctorado: Paula Benaglia, Roberto Gamen y Ruben Díaz. Gracias por el tiempo que le dedicaron y por los aportes que le hicieron al trabajo ... cada uno aportó algo diferente de los demás, desde su experiencia y 
punto de vista ... eso fue muy interesante.

Rubén también quiero agradecerte por las oportunidades que me diste y el espacio que me generaste, por la confianza en mi trabajo, por todo lo que aprendí en este tiempo y lo que seguiré aprendiendo ...

A las chicas del obser: Vero, Ani, Anabella, Clau, Andre y Anto, fue una gran suerte habernos conocido y que formen parte de mi vida. En particular durante esta última etapa, les agradezco las cadenas interminables de emails, las fotos desde todos los lugares del globo, las carreras por enviarme los papers que les pedía ... la forma que encontraron para estar siempre presentes aun cuando nos hemos visto tan poco ... es lindo saberlas cerca. Vero, a vos también te agradezco por el biombo que nunca pusimos, por los miles de mates (incluidos los horribles) que compartimos, por las conversaciones que terminaban con abrazos, por las carcajadas hasta que nos dolía la panza (o se nos piantaba un lagrimón!) ... por todas las emociones que compartimos durante todos estos años ... y los que vendrán ...

A mis amigas de la vida: Comi, lelca, Mathilde y Sofi, siempre siempre están cerca.

A mis amigos extremos: Lau, Pablo y Seba por los caminos, paisajes, aventuras y sueños que transitamos juntos ( $\mathrm{y}$ de alma) ... y por los senderos que están esperando vernos pasar ...

A Alejandro por compartir conmigo cientos de noches con historias y risas, por los amigos que me presentaste, por generar y motivar en mi otras ideas, por la belleza, honestidad y sensibilidad de tus argumentos.

A Andy por tu amistad incondicional, por esa forma tan especial de estar siempre presente, por la sinceridad y por muchos de tus emails que he releído hasta aprendérmelos de memoria.

A mi familia, mis viejos: Horacio y Beti y mis hermanos: Ari, Vale, Seba y Meche. Un conjunto de lo mas heterogéneo que conforma un equipo fuerte, unido y único. Sin el apoyo de mi familia no hubiera logrado nada de esto, todo sería más difícil y, sin dudas, mucho más aburrido! En particular a mis viejos les quiero agradecer los buenos ejemplos, la confianza y las oportunidades que me brindaron siempre.

A Bastiaan, por la vida y los sueños que compartimos, por cada uno de los desayunos y todos mis postres, por tu generosidad en todo, por que sos tan completamente lindo, por tanto amor ... que me hace ansiar ser mejor para merecerlo.

... los agradecimientos comenzaron a escribirse mucho antes de haber empezado esta Tesis de Doctorado y se continuarán escribiendo mucho después de haberla terminado ...

C. F. 


\section{Bibliografía}

Andersen, M., Zinnecker, H., Moneti, A., McCaughrean, M. J., Brandl, B., Brandner, W., Meylan, G., \& Hunter, D. 2009, ApJ, 707, 1347

Barbá, R. H., Maíz Apellániz, J., Pérez, E., Rubio, M., Bolatto, A., Fariña, C., Bosch, G., \& Walborn, N. R. 2009, Ap\&SS, 324, 309

Barbosa, C. L., Blum, R. D., Conti, P. S., Damineli, A., \& Figuerêdo, E. 2008, ApJL, 678, L55

Bastian, N., Covey, K. R., \& Meyer, M. R. 2010, ARA\&A, 48, 339

Beltrán, M. T., Cesaroni, R., Neri, R., Codella, C., Furuya, R. S., Testi, L., \& Olmi, L. 2004, ApJL, 601, L187

Bertoldi, F., Timmermann, R., Rosenthal, D., Drapatz, S., \& Wright, C. M. 1999, A\&A, 346, 267

Bessell, M. S. 2005, ARA\&A, 43, 293

Bik, A., Kaper, L., Hanson, M. M., \& Smits, M. 2005a, A\&A, 440, 121

Bik, A., Kaper, L., Thi, W., \& Waters, R. 2005b, in IAU Symposium, Vol. 227, Massive Star Birth: A Crossroads of Astrophysics, ed. R. Cesaroni, M. Felli, E. Churchwell, \& M. Walmsley, 53-58

Bik, A., Kaper, L., \& Waters, L. B. F. M. 2006, A\&A, 455, 561

Bik, A., Lenorzer, A., Kaper, L., Comerón, F., Waters, L. B. F. M., de Koter, A., \& Hanson, M. M. 2003, A\&A, 404, 249

Binney, J. \& Merrifield, M. 1998, Galactic Astronomy, ed. Binney, J. \& Merrifield, M.

Bonnell, I. A., Bate, M. R., Clarke, C. J., \& Pringle, J. E. 1997, MNRAS, 285, 201 
-. 2001, MNRAS, 323, 785

Bonnell, I. A., Bate, M. R., \& Zinnecker, H. 1998, MNRAS, 298, 93

Bosch, G., Terlevich, E., \& Terlevich, R. 2002, MNRAS, 329, 481

Brandner, W., Grebel, E. K., Barbá, R. H., Walborn, N. R., \& Moneti, A. 2001, AJ, 122, 858

Bruhweiler, F. C., Miskey, C. L., \& Smith Neubig, M. 2003, AJ, 125, 3082

Campbell, A. W. \& Terlevich, R. 1984, MNRAS, 211, 15

Cesaroni, R., Galli, D., Lodato, G., Walmsley, C. M., \& Zhang, Q. 2007, Protostars and Planets V, 197

Chabrier, G. 2003, PASP, 115, 763

Chini, R., Hoffmeister, V., Kimeswenger, S., Nielbock, M., Nürnberger, D., Schmidtobreick, L., \& Sterzik, M. 2004, Nature, 429, 155

Churchwell, E. \& Goss, W. M. 1999, ApJ, 514, 188

Cioni, M., Irwin, M., Ferguson, A. M. N., McConnachie, A., Conn, B. C., Huxor, A., Ibata, R., Lewis, G., \& Tanvir, N. 2008, A\&A, 487, 131

Clarke, C. J. 2009, Ap\&SS, 324, 121

Conti, P. S. \& Massey, P. 1981, ApJ, 249, 471

Davis, L. E. 1994, A Reference Guide to the IRAF/DAOPHOT Package

de Vaucouleurs, G., de Vaucouleurs, A., Corwin, Jr., H. G., Buta, R. J., Paturel, G., \& Fouque, P. 1991, S\&T, 82, 621

Diaz, A. I., Terlevich, E., Pagel, B. E. J., Vilchez, J. M., \& Edmunds, M. G. 1987, MNRAS, 226, 19

Dodorico, S., Dopita, M. A., \& Benvenuti, P. 1980, A\&AS, 40, 67

Dodorico, S. \& Rosa, M. 1981, ApJ, 248, 1015

Draine, B. T. 1989, in ESA Special Publication, Vol. 290, Infrared Spectroscopy in Astronomy, ed. E. Böhm-Vitense, 93-98

Draine, B. T. 2003, ARA\&A, 41, 241

Drissen, L., Crowther, P. A., Úbeda, L., \& Martin, P. 2008, MNRAS, 389, 1033 
Drissen, L., Moffat, A. F. J., \& Shara, M. M. 1993, AJ, 105, 1400

Elmegreen, B. G. 1998, ArXiv Astrophysics e-prints

Elmegreen, B. G. 2001, in Astronomical Society of the Pacific Conference Series, Vol. 243, From Darkness to Light: Origin and Evolution of Young Stellar Clusters, ed. T. Montmerle \& P. André, 255

-. 2011, ArXiv e-prints

Engargiola, G., Plambeck, R. L., Rosolowsky, E., \& Blitz, L. 2003, ApJS, 149, 343

Fariña, C., Bosch, G. L., Morrell, N. I., Barbá, R. H., \& Walborn, N. R. 2009, AJ, 138, 510

Fitzpatrick, E. L. 1999, PASP, 111, 63

Follert, R., Linz, H., Stecklum, B., van Boekel, R., Henning, T., Feldt, M., Herbst, T. M., \& Leinert, C. 2010, A\&A, 522, A17

Freedman, W. L., Madore, B. F., Gibson, B. K., Ferrarese, L., Kelson, D. D., Sakai, S., Mould, J. R., Kennicutt, Jr., R. C., Ford, H. C., Graham, J. A., Huchra, J. P., Hughes, S. M. G., Illingworth, G. D., Macri, L. M., \& Stetson, P. B. 2001, ApJ, 553, 47

Furuya, R. S., Kitamura, Y., Saito, M., Kawabe, R., \& Wootten, H. A. 1999, ApJ, 525, 821

Glass, I. S. 1999, Handbook of Infrared Astronomy

González Delgado, R. M. \& Pérez, E. 2000, MNRAS, 317, 64

Haisch, Jr., K. E., Lada, E. A., \& Lada, C. J. 2000, AJ, 120, 1396

-. 2001, ApJL, 553, L153

Hanson, M. M., Howarth, I. D., \& Conti, P. S. 1997, ApJ, 489, 698

Hodapp, K. W., Jensen, J. B., Irwin, E. M., Yamada, H., Chung, R., Fletcher, K., Robertson, L., Hora, J. L., Simons, D. A., Mays, W., Nolan, R., Bec, M., Merrill, M., \& Fowler, A. M. 2003, PASP, 115, 1388

Hunter, D. A., Baum, W. A., O'Neil, Jr., E. J., \& Lynds, R. 1996, ApJ, 456, 174

Israel, F. P. \& van der Kruit, P. C. 1974, A\&A, 32, 363

Ivanov, G. R. \& Kunchev, P. Z. 1985, Ap\&SS, 116, 341

Johnson, H. L. 1965, ApJ, 141, 923 
-. 1966, ARA\&A, 4, 193

Johnson, H. L., Iriarte, B., Mitchell, R. I., \& Wisniewski, W. Z. 1966, Communications of the Lunar and Planetary Laboratory, 4, 99

Johnson, H. L., MacArthur, J. W., \& Mitchell, R. I. 1968, ApJ, 152, 465

Jørgensen, J. K., van Dishoeck, E. F., Visser, R., Bourke, T. L., Wilner, D. J., Lommen, D., Hogerheijde, M. R., \& Myers, P. C. 2009, A\&A, 507, 861

Kennicutt, Jr., R. C. 1984, ApJ, 287, 116

Kraus, S., Hofmann, K., Menten, K. M., Schertl, D., Weigelt, G., Wyrowski, F., Meilland, A., Perraut, K., Petrov, R., Robbe-Dubois, S., Schilke, P., \& Testi, L. 2010, Nature, 466, 339

Kroupa, P. 2002, in Astronomical Society of the Pacific Conference Series, Vol. 285, Modes of Star Formation and the Origin of Field Populations, ed. E. K. Grebel \& W. Brandner, 86

Kumar, M. S. N., Bachiller, R., \& Davis, C. J. 2002, ApJ, 576, 313

Leggett, S. K., Currie, M. J., Varricatt, W. P., Hawarden, T. G., Adamson, A. J., Buckle, J., Carroll, T., Davies, J. K., Davis, C. J., Kerr, T. H., Kuhn, O. P., Seigar, M. S., \& Wold, T. 2006, MNRAS, 373, 781

Leggett, S. K., Hawarden, T. G., Currie, M. J., Adamson, A. J., Carroll, T. C., Kerr, T. H., Kuhn, O. P., Seigar, M. S., Varricatt, W. P., \& Wold, T. 2003, MNRAS, 345, 144

Li, A. \& Draine, B. T. 2001, ApJL, 550, L213

Maíz-Apellániz, J. 2000, PASP, 112, 1138

-. 2001, ApJ, 563, 151

-. 2004, PASP, 116, 859

Maíz-Apellániz, J., Pérez, E., \& Mas-Hesse, J. M. 2004, AJ, 128, 1196

Martin, P. G. \& Whittet, D. C. B. 1990, ApJ, 357, 113

Martín-Hernández, N. L., Esteban, C., Mesa-Delgado, A., Bik, A., \& Puga, E. 2008, A\&A, 482, 215

Martins, F., Genzel, R., Hillier, D. J., Eisenhauer, F., Paumard, T., Gillessen, S., Ott, T., \& Trippe, S. 2007, A\&A, 468, 233

Martins, F. \& Plez, B. 2006, A\&A, 457, 637 
Massey, P. \& Davis, L. E. 1992, A User's Guide to Stellar CCD Photometry with IRAF

Massey, P. \& Hunter, D. A. 1998, in Astronomical Society of the Pacific Conference Series, Vol. 131, Properties of Hot Luminous Stars, ed. I. Howarth, 355

McKee, C. F. \& Tan, J. C. 2003, ApJ, 585, 850

Miskey, C. L. \& Bruhweiler, F. C. 2003, AJ, 125, 3071

Miura, R., Okumura, S. K., Tosaki, T., Tamura, Y., Kurono, Y., Kuno, N., Nakanishi, K., Sakamoto, S., Hasegawa, T., \& Kawabe, R. 2010, ApJ, 724, 1120

Moffat, A. F. J. 1969, A\&A, 3, 455

Noriega-Crespo, A., Morris, P., Marleau, F. R., Carey, S., Boogert, A., van Dishoeck, E., Evans, II, N. J., Keene, J., Muzerolle, J., Stapelfeldt, K., Pontoppidan, K., Lowrance, P., Allen, L., \& Bourke, T. L. 2004, ApJS, 154, 352

O'Dell, C. R. 2009, PASP, 121, 428

Osterbrock, D. E. \& Ferland, G. J. 2006, Astrophysics of Gaseous Nebulae and Active Galactic Nuclei, University Science Books, 2006

Relaño, M. \& Kennicutt, R. C. 2009, ApJ, 699, 1125

Rieke, G. H. \& Lebofsky, M. J. 1985, ApJ, 288, 618

Rosa, M. \& Dodorico, S. 1982, A\&A, 108, 339

Rosenthal, D., Bertoldi, F., \& Drapatz, S. 2000, A\&A, 356, 705

Rubio, M., Barbá, R. H., Walborn, N. R., Probst, R. G., García, J., \& Roth, M. R. 1998, AJ, 116,1708

Rubio, M., Contursi, A., Lequeux, J., Probst, R., Barbá, R., Boulanger, F., Cesarsky, D., \& Maoli, R. 2000, A\&A, 359, 1139

Salpeter, E. E. 1955, ApJ, 121, 161

Sandage, A. \& Tammann, G. A. 1974, ApJ, 190, 525

Schlegel, D. J., Finkbeiner, D. P., \& Davis, M. 1998, ApJ, 500, 525

Schreyer, K., Semenov, D., Henning, T., \& Forbrich, J. 2006, ApJL, 637, L129

Selman, F., Melnick, J., Bosch, G., \& Terlevich, R. 1999, A\&A, 347, 532 
Solomon, P. M., Downes, D., \& Radford, S. J. E. 1992, ApJL, 387, L55

Stahler, S. W. \& Palla, F. 2004, The Formation of Stars, WilLEY-VCH, 2004

Stephens, D. C. \& Leggett, S. K. 2004, PASP, 116, 9

Stetson, P. B. 1987, PASP, 99, 191

Tachihara, K., Rengel, M., Nakajima, Y., Yamaguchi, N., André, P., Neuhäuser, R., Onishi, T., Fukui, Y., \& Mizuno, A. 2007, ApJ, 659, 1382

Tenorio-Tagle, G., Muñoz-Tuñón, C., Pérez, E., Maíz-Apellániz, J., \& Medina-Tanco, G. 2000, ApJ, 541, 720

Terlevich, E., Díaz, A. I., Terlevich, R., González-Delgado, R. M., Pérez, E., \& García Vargas, M. L. 1996, MNRAS, 279, 1219

Thilker, D. A. 2000, in Proceedings 232. WE-Heraeus Seminar, ed. E. M. Berkhuijsen, R. Beck, \& R. A. M. Walterbos, 3-10

Tokunaga, A. T. 2000, Infrared Astronomy, 143

Tokunaga, A. T. \& Vacca, W. D. 2007, in Astronomical Society of the Pacific Conference Series, Vol. 364, The Future of Photometric, Spectrophotometric and Polarimetric Standardization, ed. C. Sterken, 409

Tosaki, T., Miura, R., Sawada, T., Kuno, N., Nakanishi, K., Kohno, K., Okumura, S. K., \& Kawabe, R. 2007, ApJL, 664, L27

Viallefond, F., Boulanger, F., Cox, P., Lequeux, J., Perault, M., \& Vogel, S. N. 1992, A\&A, 265,437

Vilchez, J. M., Pagel, B. E. J., Diaz, A. I., Terlevich, E., \& Edmunds, M. G. 1988, MNRAS, 235,633

Walborn, N. R. 1991, in IAU Symposium, Vol. 148, The Magellanic Clouds, ed. R. Haynes \& D. Milne, 145

Walborn, N. R. \& Blades, J. C. 1997, ApJS, 112, 457

Walborn, N. R. \& Parker, J. W. 1992, ApJL, 399, L87

Wegner, W. 2007, MNRAS, 374, 1549

Weidner, C., Bonnell, I. A., \& Zinnecker, H. 2010, ApJ, 724, 1503 
Yang, H., Chu, Y., Skillman, E. D., \& Terlevich, R. 1996, AJ, 112, 146

Zinnecker, H. \& Yorke, H. W. 2007, ARA\&A, 45, 481 